VNIVERSIDAD

DSALAMANCA

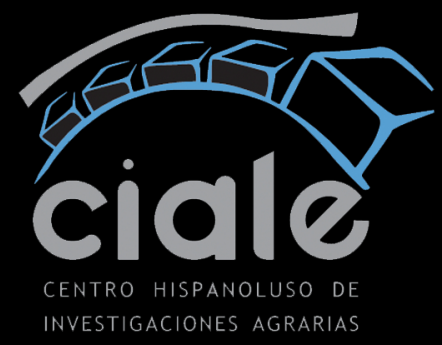

Expresión de los genes fffl y ffth del hongo patógeno fusarium oxysporum 



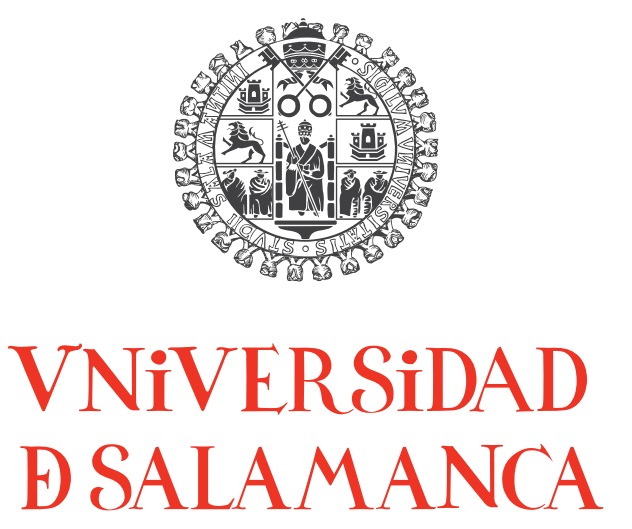

CENTRO HISPANO LUSO DE INVESTIGACIONES AGRARIAS DEPARTAMENTO DE MICROBIOLOGÍA Y GENÉTICA ÁREA DE GENÉTICA

\title{
"Expresión de los genes ftf1 y ftf2 del hongo patógeno Fusarium oxysporum"
}

\author{
Memoria que presenta José Javier de Vega Bartol para optar al \\ grado de Doctor
}

Salamanca, a 11 de mayo de 2009 


\section{JOSÉ MARÍA DÍAZ MÍNGUEZ, PROFESOR TITULAR DE GENÉTICA DEL ÁREA DE GENÉTICA DEL DEPARTAMENTO DE MICROBIOLOGÍA Y GENÉTICA DE LA UNIVERSIDAD DE SALAMANCA}

\section{AUTORIZA}

La presentación y defensa de la Tesis Doctoral titulada: "Expresión de los genes ftf1 y ftf2 en el hongo patógeno Fusarium oxysporum", para optar al grado de Doctor por la Universidad de Salamanca, que ha sido realizada por D. José Javier de Vega Bartol bajo mi dirección, en el Área de Genética del Departamento de Microbiología y Genética.

En Salamanca, a 11 de mayo de 2009

Fdo. Dr. D. José María Díaz Mínguez 


\section{JOSÉ MARÍA DÍAZ MÍNGUEZ, PROFESOR TITULAR DE GENÉTICA DEL ÁREA DE GENÉTICA DEL DEPARTAMENTO DE MICROBIOLOGÍA Y GENÉTICA DE LA UNIVERSIDAD DE SALAMANCA}

\section{CERTIFICA}

que D. José Javier de Vega Bartol ha realizado en el Área de Genética del Departamento de Microbiología y Genética el trabajo titulado: "Expresión de los genes ftf1 y ftf2 en el hongo patógeno Fusarium oxysporum", bajo mi dirección para optar al grado de Doctor por la Universidad de Salamanca.

Y para que así conste, extiendo el presente certificado en Salamanca, a 11 de mayo de 2009

Fdo. Dr. D. José María Díaz Mínguez 


\section{D. ÁNGEL DOMÍNGUEZ OLAVARRI, CATEDRÁTICO DE MICROBIOLOGÍA Y DIRECTOR DEL DEPARTAMENTO DE MICROBIOLOGÍA Y GENÉTICA DE LA UNIVERSIDAD DE SALAMANCA}

\section{CERTIFICA}

Que la memoria titulada: "Expresión de los genes ftf1 y ftf2 en el hongo patógeno Fusarium oxysporum", presentada por D. José Javier de Vega Bartol para optar al grado de Doctor por la Universidad de Salamanca, ha sido realizada bajo la dirección del doctor D. José María Díaz Mínguez, en el Área de Genética del Departamento de Microbiología y Genética.

En Salamanca, a de mayo de 2009

Fdo. Dr. D. Ángel Domínguez Olavarri 


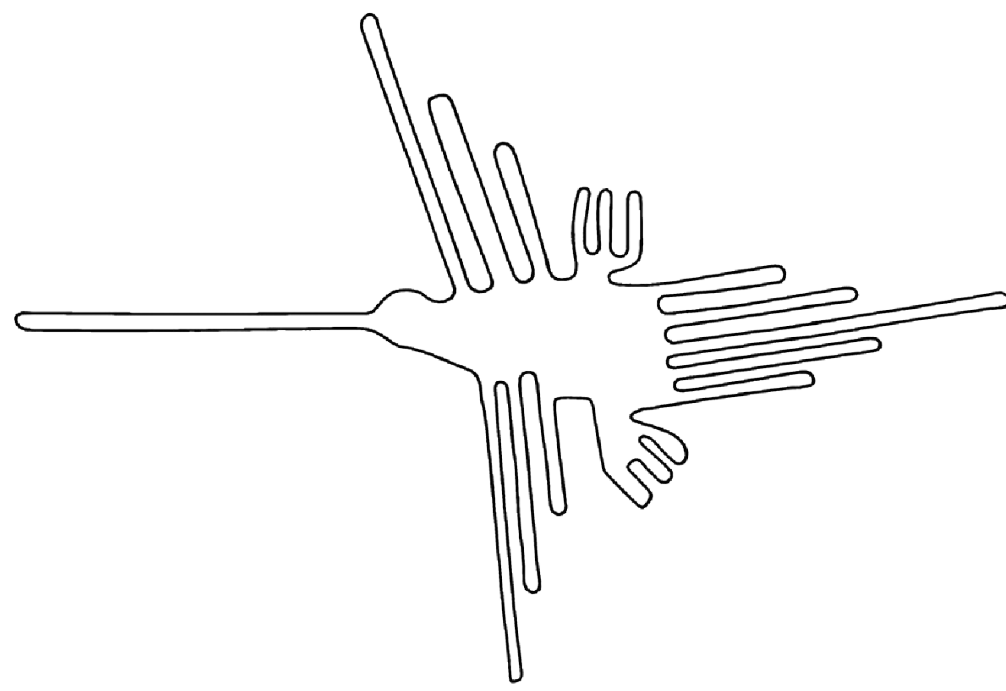

"Un día un incendió comenzó a devorar el bosque y todos los animales empezaron a huir corriendo y volando, tratando de escapar lo más lejos posible de las llamas. Cuando habian alcanzado cierta distancia, los animales más fuertes y valientes se pararon para ver el fuego devorar sus hogares. Sin embargo, cuando se giraron vieron una estela verde y roja cruzando el cielo, yendo y viniendo desde un brillante lago a lo profundo del bosque en llamas. Era un colibri, que en su pequeño pico transportaba unas pocas gotas de agua para tratar de apagar el incendio.

Los animales miraban al colibri con incredulidad, cuando el león rugió: -Colibri, ¿Estás loco?, ¿Qué crees gue vas a conseguir alli con tu gota de agua?. Consciente de la imposibilidad de la tarea, el colibri le contestó: -Habré hecho mi parte."

(cuento popular)

Gracias...

A mis padres y hermanos, por ser mis cimientos.

A los compañeros y amigos del labo y del centro, a los amigos "de fuera", gue ayudan a llevar mejor "esas cosas" gue tiene la ciencia. A todos los que, y son tantos, me han regalado sus gotas o sus litros de ayuda, comprensión y sabiduria, sin vosotros no existiria esta tesis. A mi director de tesis y los otros profesores del grupo. 

Lo más difícil de aprender en la vida es qué puente hay que cruzar y qué puente hay que quemar 
Foto de portada: Imagen obtenida mediante microscopio confocal del corte transversal de la raíz principal de una planta de judía fijada con ioduro de propidio (color rojo) tras cinco días infectada con una estirpe virulenta de $F$. oxysporum f.sp. phaseoli (FOP-SP2) que porta una construcción de expresión de la proteína GFP (color verde). Cortesía de Lina Patricia Rivera Rodríguez \& 
Índice de materias . .1

Índice de figuras VI

Índice de tablas

Summary $\mathrm{X}$

Resumen $\mathbf{X V I}$

Símbolos y abreviaturas IXX

1. - Introducción 1

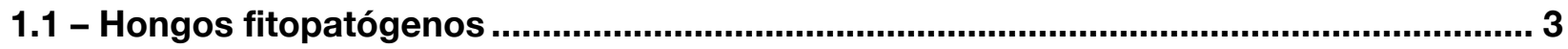

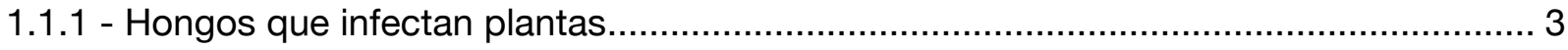

1.1 .2 - Interacción entre la planta y el patógeno …............................................................... 4

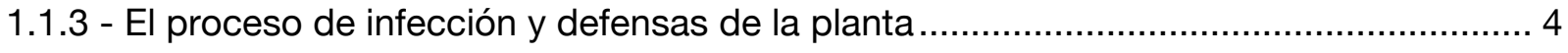

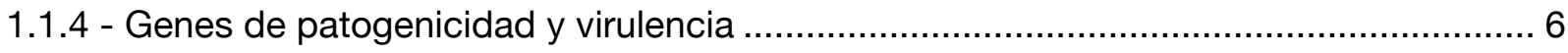

1.1 .5 - Silenciamiento mediado por RNA en hongos filamentosos ...................................... 8

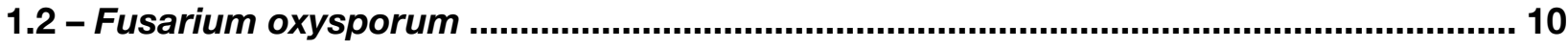

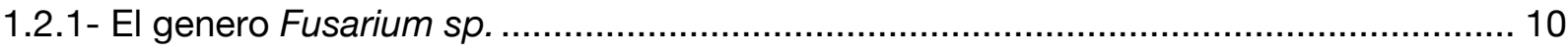

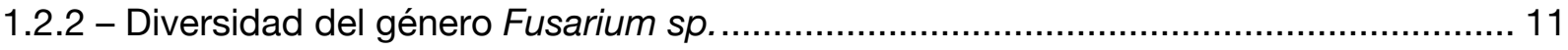

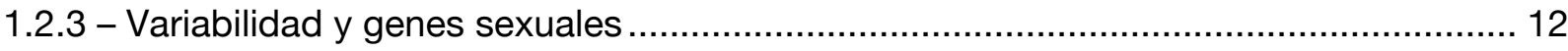

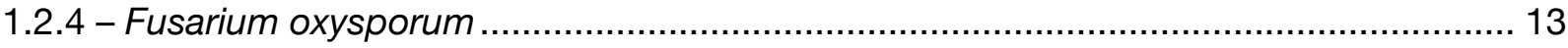

1.2.5 - Formas especiales (formae speciales) de Fusarium oxysporum ............................... 14

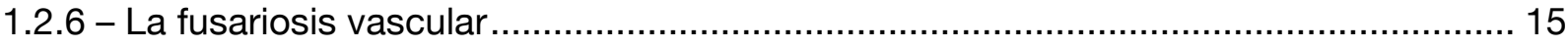

1.2.7 - F. oxysporum f.sp. phaseoli: la fusariosis vascular de la judía .................................. 16

1.2.8 - F. oxysporum f.sp. lycopersici: La fusariosis vascular del tomate ............................ 17

1.2.9 - Bases moleculares de la patogenicidad de F. oxysporum ..................................... 18

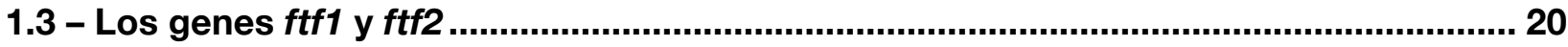

1.3.1 - Diversidad de F. oxysporum f.sp. phaseoli en España ........................................... 20

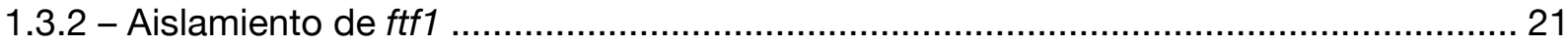

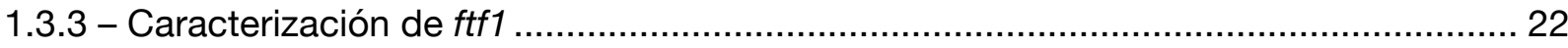

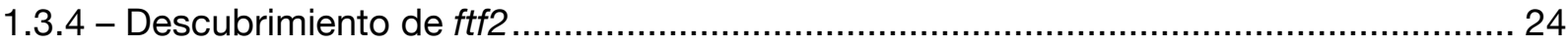

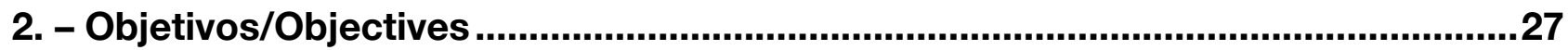

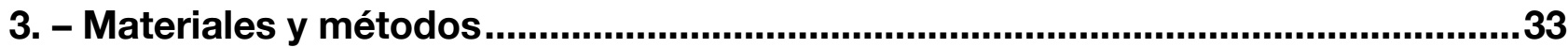

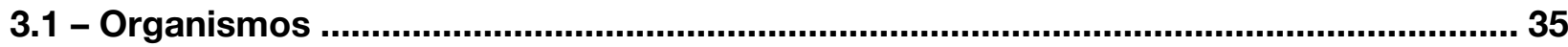




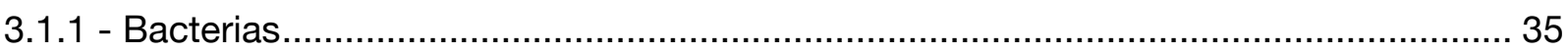

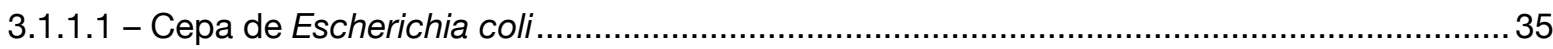

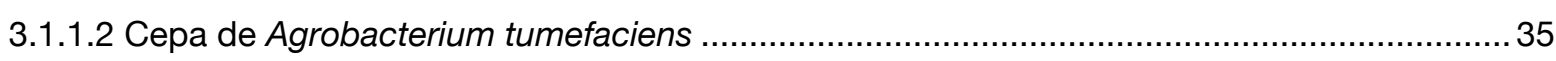

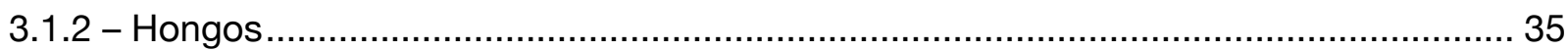

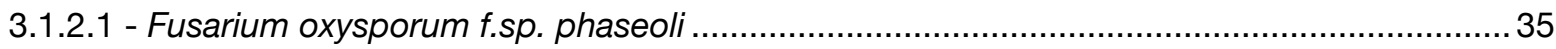

3.1.2.2 - Otras formas especiales de Fusarium oxysporum ........................................................ 35

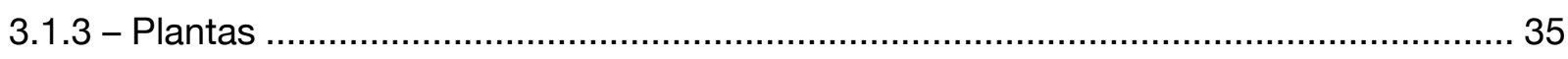

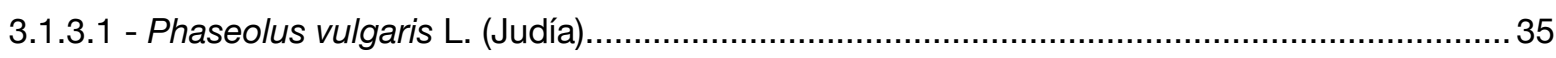

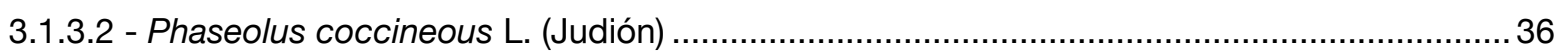

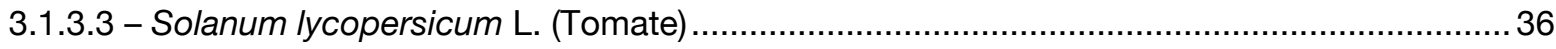

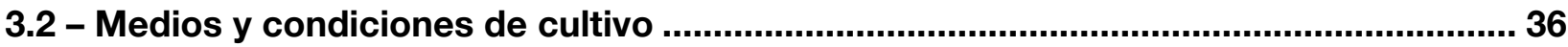

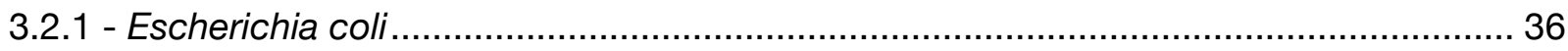

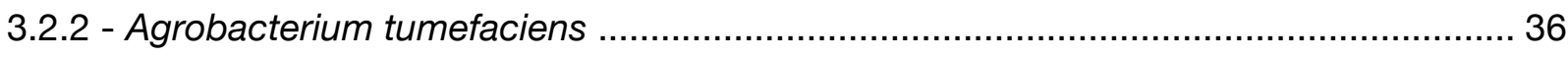

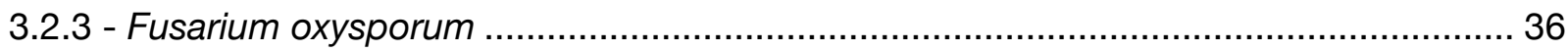

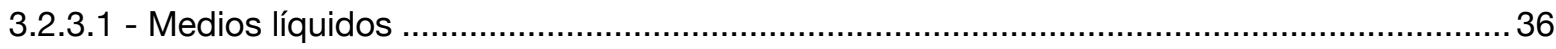

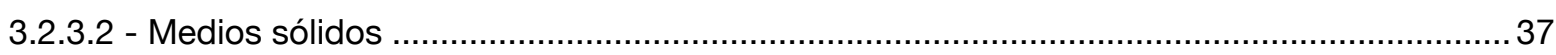

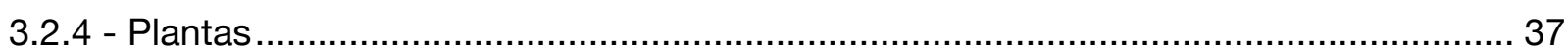

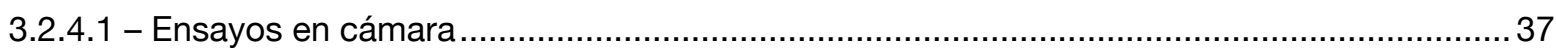

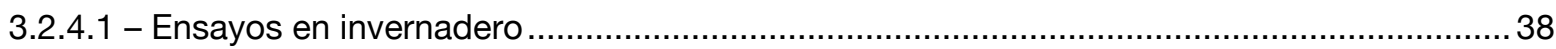

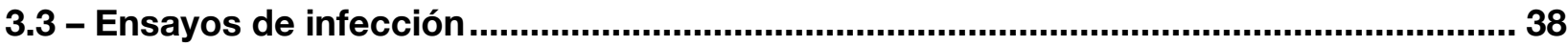

3.4 - Estudio de Grupos de Compatibilidad Vegetativa (VCG) .......................................... 39

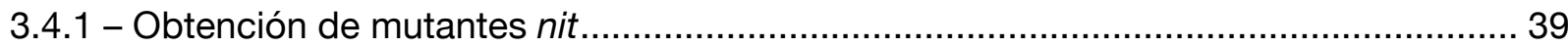

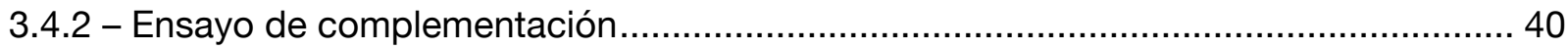

3.5 - Obtención y cuantificación de ácidos nucleicos .................................................. 40

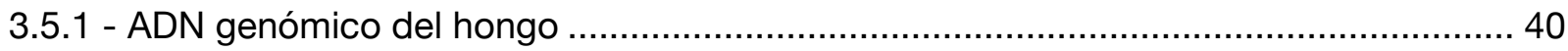

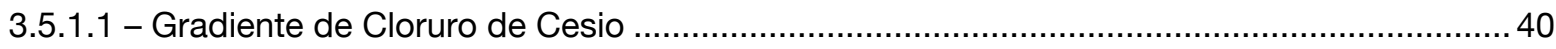

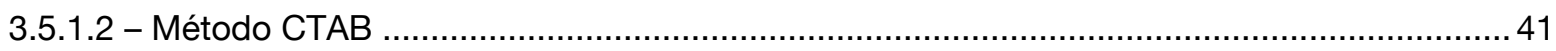

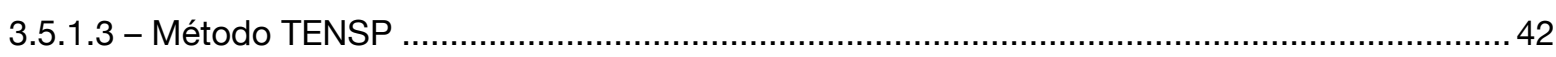

3.5.1.4 - Método rápido a partir de cultivo en placa ................................................................. 42

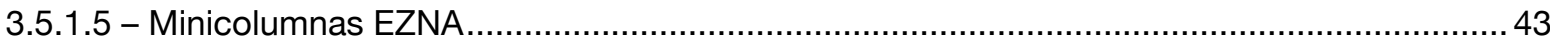

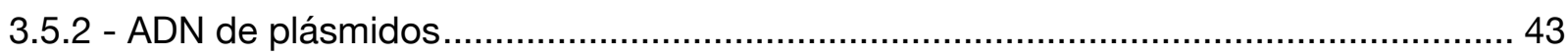

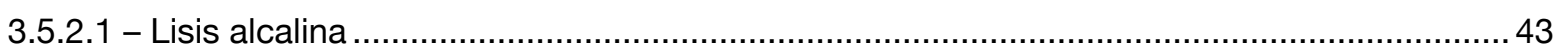

3.5.2.2 - "High Pure Plasmid Isolation Kit" y "Fastprep Eppendorf Kit" .......................................... 44

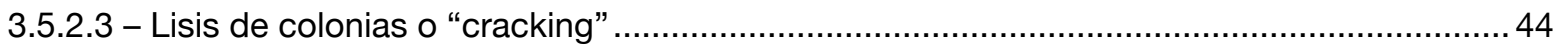

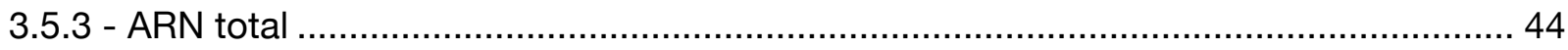

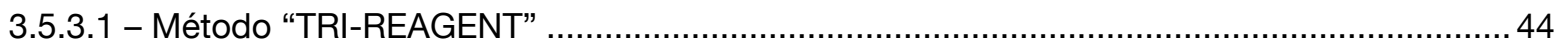

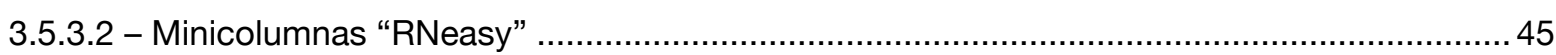

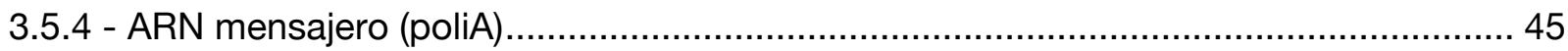

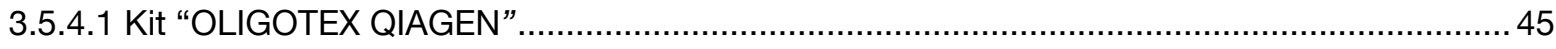




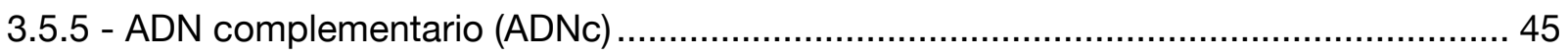

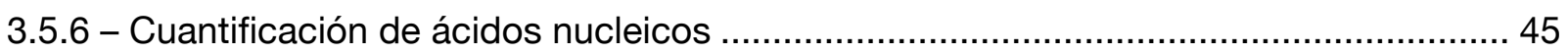

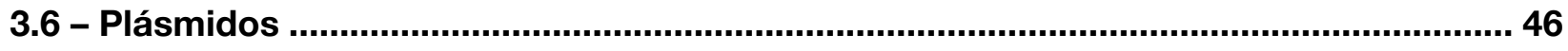

3.6.1 - Vectores de clonación pGEM-T y pGEM-T-Easy ............................................... 46

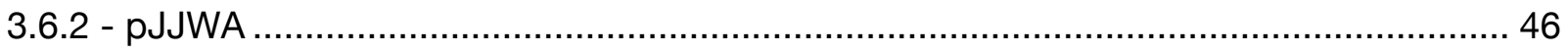

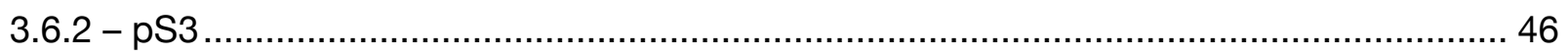

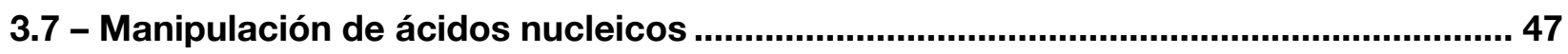

3.7.1 - Tratamiento con enzimas de restricción ................................................................. 47

3.7.2 - Defosforilación con Fosfatasa Alcalina .............................................................. 47

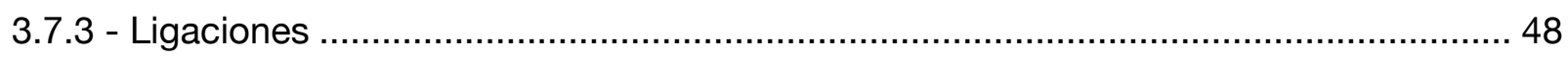

3.7.4 - Recuperación de ADN a partir de soluciones ................................................... 48

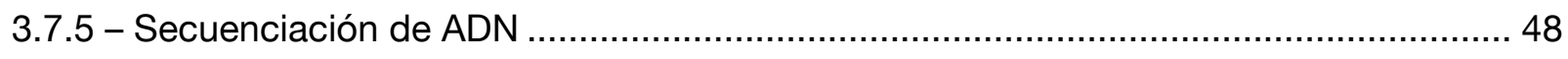

3.8 - Electroforesis en geles de agarosa................................................................................ 48

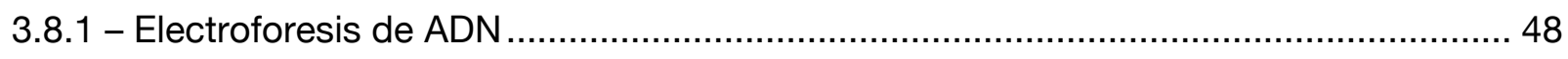

3.8.2 - Recuperación de ADN a partir de fragmentos de agarosa ...................................... 49

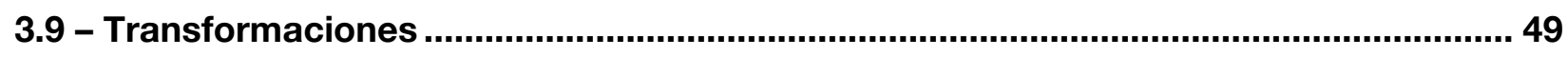

3.9.1 - Transformación de Escherichia coli ................................................................ 49

3.9.1.1 - Preparación de células electrocompetentes............................................................... 49

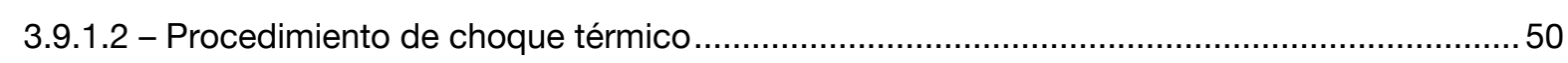

3.9.2 - Transformación de Agrobacterium tumefaciens ................................................. 51

3.9.2.1 - Preparación de células competentes ........................................................................ 51

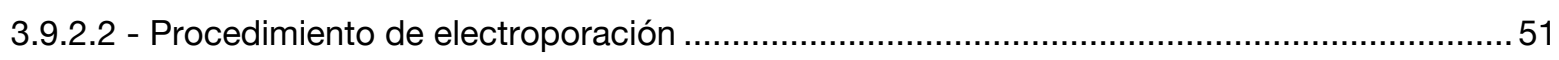

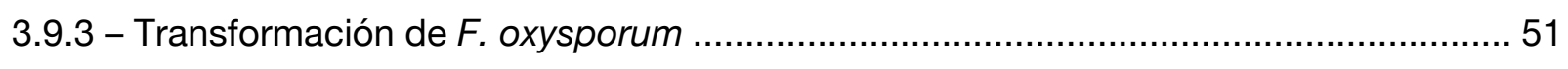

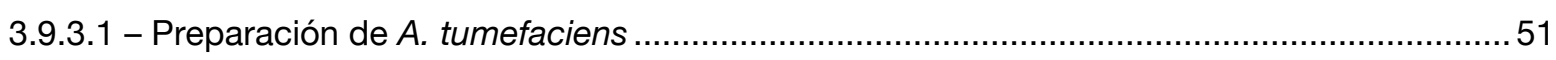

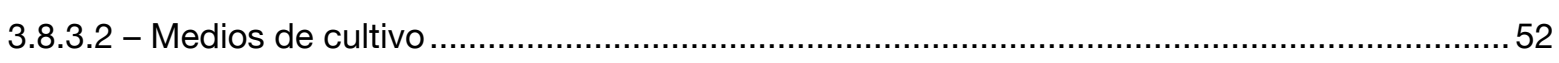

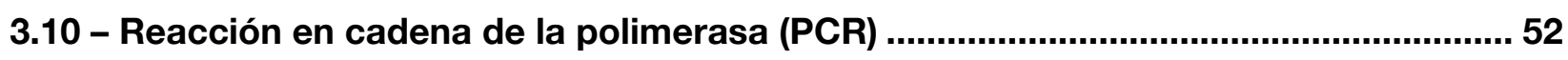

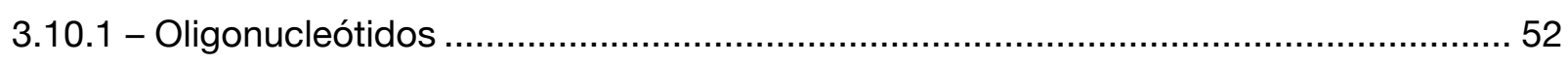

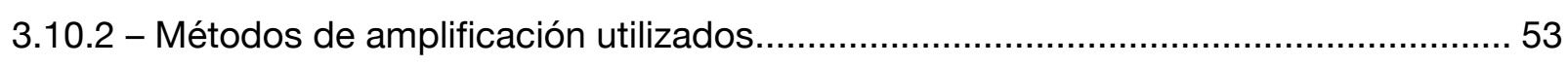

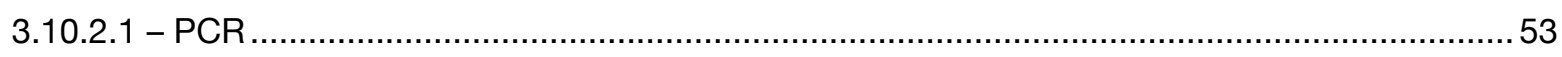

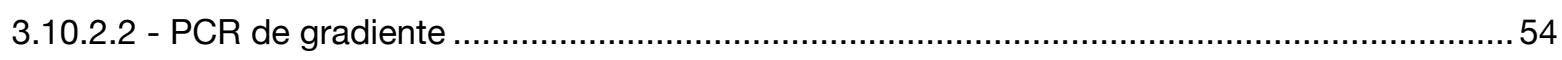

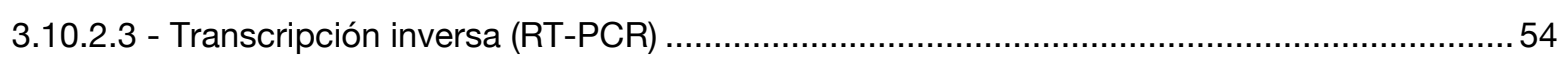

3.10.3 - Análisis del espaciador intergénico (IGS) de ADN ribosómico ................................ 55

3.10.4 - PCR cuantitativa (qPCR) a tiempo real............................................................. 55

3.10.4.1 - Principios teóricos de la cuantificación por PCR a tiempo real ........................................55

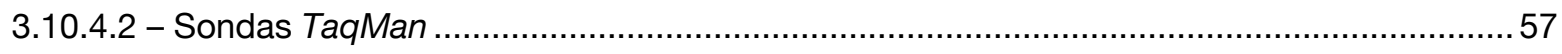

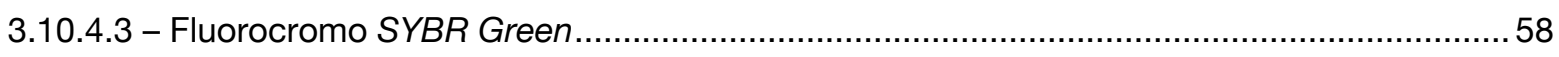

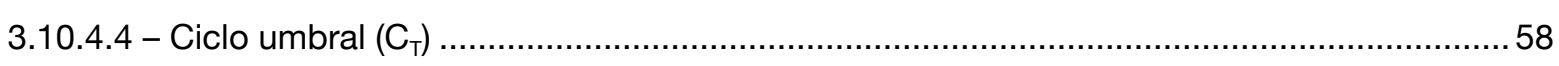

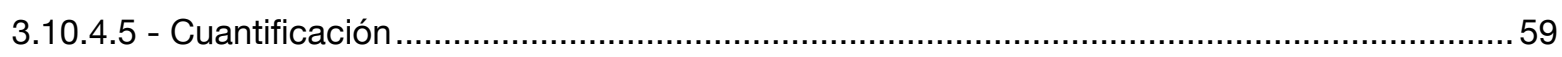




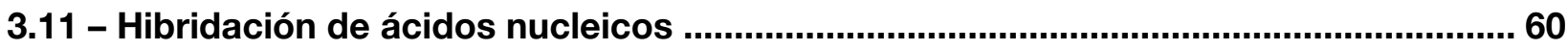

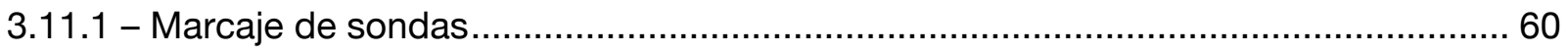

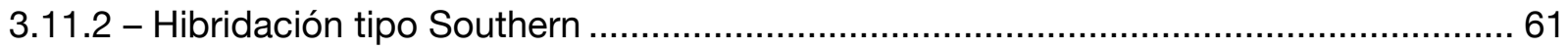

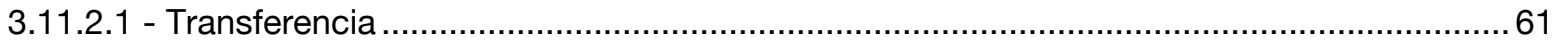

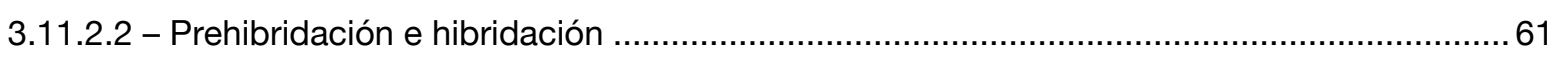

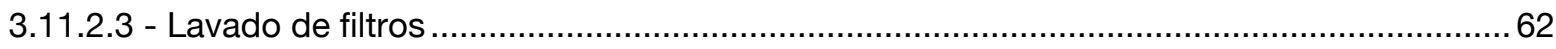

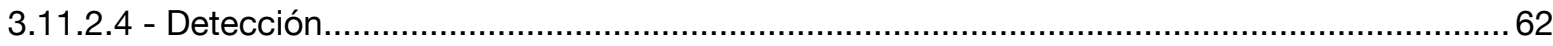

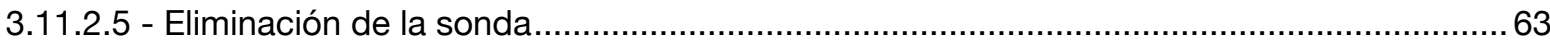

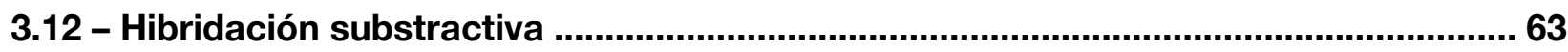

3.13 - Programas informáticos y bases de datos................................................................. 64

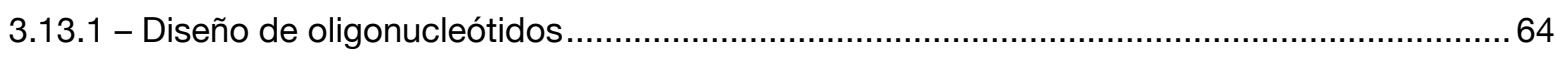

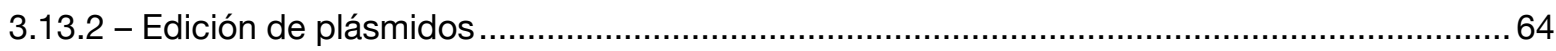

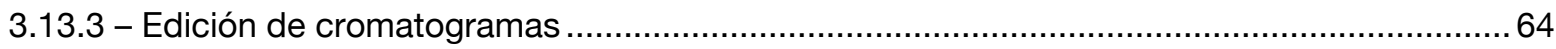

3.13.4 - Edición, alineamiento y relaciones filogenéticas de secuencias......................................... 65

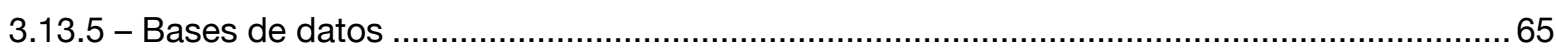

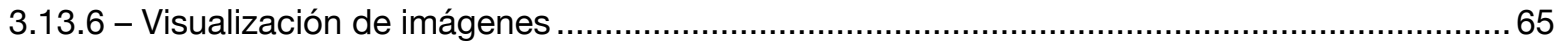

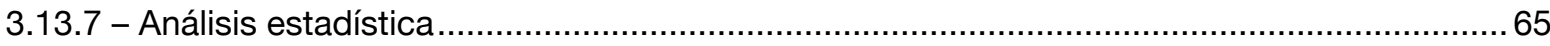

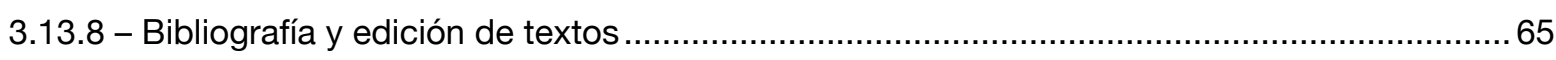

3.14 - Tabla de oligonucleótidos ............................................................................... 66

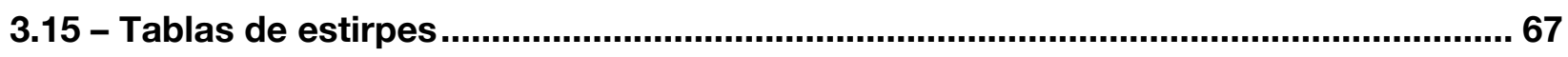

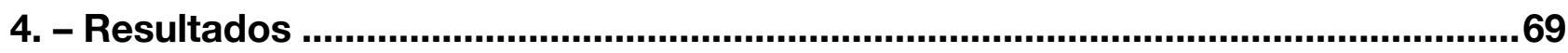

4.1 - Caracterización de aislados de $F$. oxysporum obtenidos en plantas de judión ........ 71

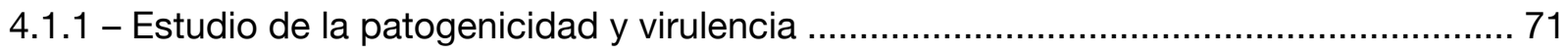

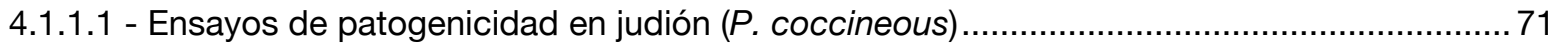

4.1.1.2 - Significación estadística de los grupos de virulencia observados ......................................74

4.1.1.3 - Ensayos de patogenicidad en judía (P. vulgaris) …........................................................ 75

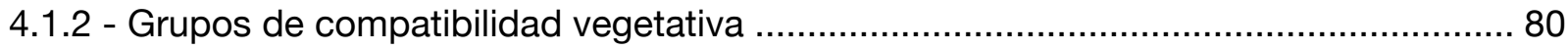

4.1.3 - Diversidad genética de los aislados obtenidos de judión: RFLP-IGS y mating-type.. 81

4.1.4 - Presencia de ftf1 y ftf2 en los aislados recogidos en judión ...................................... 82

4.2 - Expresión de los genes ftf1 y ftf2 en aislados silvestres de Fusarium oxysporum ... 87

4.2.1 - Expresión del gen ftf2 en aislados silvestres con distinta virulencia.......................... 87

4.2.1.1 - Expresión de ftf2 en cultivo líquido …………........................................................... 87

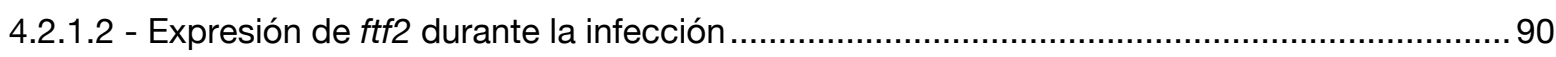

4.2.2 - Expresión de ftf1 en aislados supervirulentos ..................................................... 91

4.2.2.1 - Expresión de ftf1 en aislados supervirulentos en cultivo líquido.........................................91

4.2.2.2 - Expresión de ftf1 en aislados supervirulentos durante el proceso de infección ..................92

4.3 - Genómica comparada de ftf1 y ftf2 en el género Fusarium ..................................... 95

4.3.1 - ftf1 y ftf2 en Fusarium verticilloides, Fusarium graminearum y Fusarium oxysporum. 95 
4.3.1.1 - Presencia de ftf1 y ftf2 en el genero Fusarium y en otros hongos filamentosos 95

4.3.1.2 - Polimorfismos del gen ftf1 en diferentes formas especiales de $F$. oxysporum. 96

4.3.1.3 - Número de copias de ftf1 en diferentes formas especiales de F. oxysporum. 97

4.3.2 - ftf1 y ftf2 en Fusarium oxysporum f.sp. lycopersici................................................ 101

4.3.2.1 - Secuencias similares a ftf1 y ftf2 en Fusarium oxysporum f.sp. lycopersici ..................... 101

4.3.2.2 - Número de copias en el genoma de F. oxysporum f.sp. lycopersici................................. 102

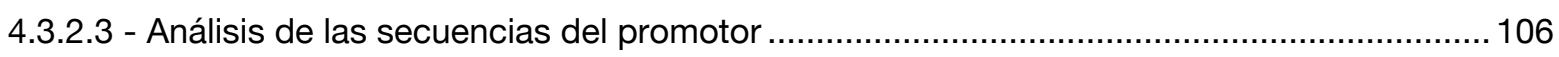

4.3.2.4 - Análisis de la región codificante y la proteína resultante ............................................... 107

4.4 - Análisis fenotípico de los transformantes silenciados en ftf1 y ftf2 ..........................113

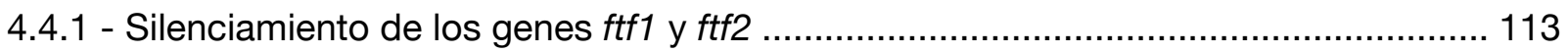

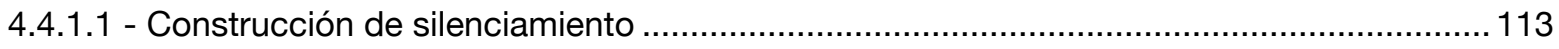

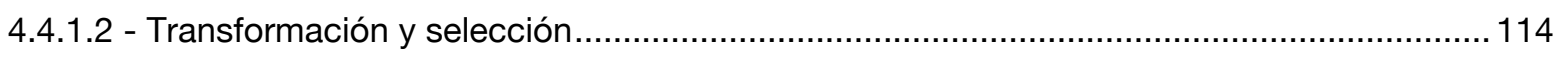

4.4.2 - Expresión de ftf2 en los transformantes silenciados............................................... 115

4.4.3 - Alteración del crecimiento y la esporulación en los transformantes silenciados ...... 119

4.4.3.1 - Fenotipo de los tranformantes silenciados de F. oxysporum f.sp. lycopersici.................119

4.4.3.2 - Crecimiento en placa de los tranformantes silenciados de F. oxysporum f.sp. phaseoli.119 4.4.3.3 - Crecimiento en medios de selección de los tranformantes silenciados de F. oxysporum

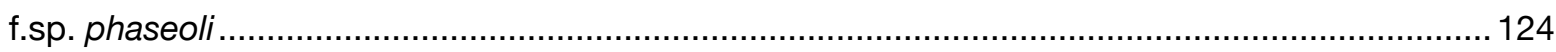

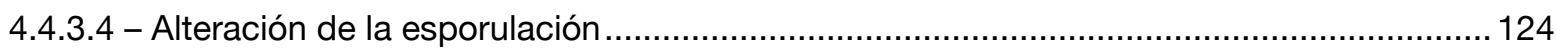

4.4.4 - Análisis de la virulencia en los transformantes silenciados ................................... 130

4.4.4.1 - Virulencia en transformantes silenciados en $\mathrm{ftf2}$.................................................. 130

4.4.4.2 - Virulencia en transformantes silenciados en ftf1 y ftf2 ............................................ 131

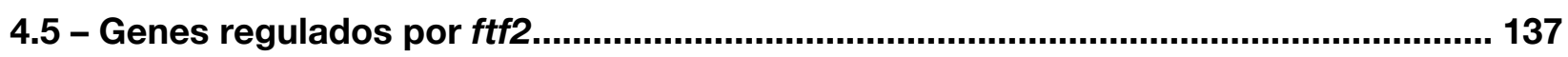

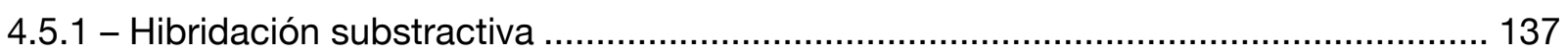

4.5.1.1 - Comparación entre SP4 y 3.01 a las 24 horas...................................................... 137

4.5.1.2 - Expresión relativa de los genes de interes en otro transformante y a distinto tiempo ..... 138

4.5.2 - Análisis comparativo de los presuntos genes expresados diferencialmente ........... 140

4.5.2.1 - Proteina aspartil proteasa ("aspar-prote") ...................................................... 140

4.5.2.2 - Proteina semejante a glutamino amidotransferasa tipo 1 (“GAT1”)...............................141

4.5.2.3 - Proteína de morfología y crecimiento de la célula (“Pal1”) .......................................... 141

4.5.2.4 - Proteina de regulación del estrés nutricional (“SIP5”) ........................................... 142

4.5.2.5 - Proteína de transporte entre vesículas intracelulares ("sec17”) ................................ 142

4.5.2.6 - Proteina de catabolismo de la taurina ("TauD") .......................................................... 143

4.5.2.7 - Proteina de regulación de la transcripción génica (“TFIID”) ...................................... 143

4.5.2.8 - Proteina piruvato descarboxilasa ("Tiamina") ....................................................... 144

4.5.2.9 - Proteína de respuesta a hipoxia mitocondrial (“hipox”) ............................................ 145

4.5.2.10 - Proteína desconocida 03747 (03747) ............................................................ 145

4.5.2.11 - Proteína desconocida 04611 (04611) ............................................................. 146

4.5.2.12 - Proteína desconocida 08338 (08338) .............................................................. 146 
5. - Discusión

5.1 - Nuevos aislados supervirulentos de F. oxysporum f.sp. phaseoli con una copia adicional de ftf1

5.2 - La expresión de ftf2 es estable durante el crecimiento y la infección, e independiente de la virulencia del aislado

5.3 - El gen ftf1 está sobreexpresado en etapas tempranas de la infección en estirpes supervirulentas y altamente virulentas

5.4 - Arquitectura genómica de ftf1 y ftf2 en el género Fusasrium y otros hongos

filamentosos

5.5 - Los transformantes silenciados muestran una reducción del crecimiento, la esporulación y, en algunos casos, de la virulencia

5.6 - La identificación de los genes presuntamente regulados por ftf2, sugiere que podría tener un papel en el metabolismo de nutrientes

6. - Conclusiones/Conclusions. 167

7. - Bibliografía 
Figura 1. 1 - Fases del proceso de infección para los distintos tipos de patógeno según su ciclo de vida

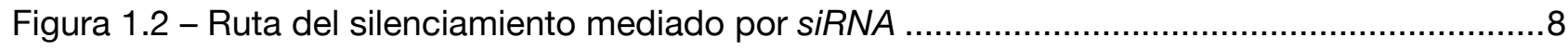

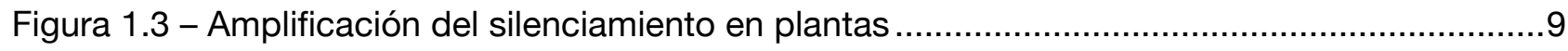

Figura 1.4 - Desarrollo de hifas de F. oxysporum tras 36 horas de cultivo en medio líquido ..........13

Figura 1.5 - Microconidios de F. oxysporum tras 16 horas de cultivo en medio líquido ................14

Figura 1.6 - Desarrollo de F. oxysporum en haces vasculares de una planta de judía..................15

Figura 1.7 - Corte transversal de tallos de plantas de judía sana e infectada ..............................15

Figura 1.8 - Detalle de la progresión de la enfermedad en una planta de judía ...........................16

Figura 1.9 - Sintomatoligía de la Fusariosis vascular en una hoja de tomate................................17

Figura 1.10 - Virulencia en cuatro variedades de judía tras la infección con $F$. oxysporum ...........21

Figura 1.11 - Hibridación Southern de ADN genómico de estirpes de F. oxysporum con las sondas B310-A280 y M18B-M19A de fff1a .........................................................................23

Figura 3.1 - Comparación entre las técnicas de PCR cuantitativa en tiempo real usando sonda

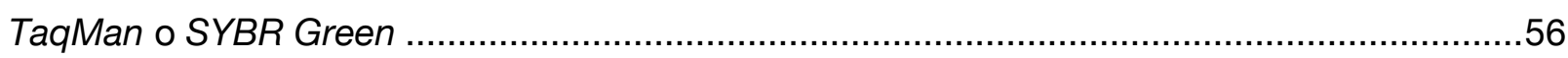

Figura 3.2 - Gráfica del $\log (\mathrm{Rn})$ frente al número de ciclos para dos reacciones en las que se señala el umbral de detección (Ct) para un umbral definido

Figura 3.3 - Posibles productos de la primera y la segunda hibridación del protocolo de hibridación substractiva

Figura 4. 1 - Virulencia de los aislados supervirulentos según su valor en la escala CIAT en plantas de judión ( $P$. coccineous) durante las cuatro primeras semanas de la infección.........71

Figura 4.2 - Detalle del desarrollo de la sintomatología tras dos semanas tras la infección en plantas infectadas con FOP-SP14.

Figura 4. 3 - Virulencia de los aislados altamente virulentos según su valor en la escala CIAT en plantas de judión ( $P$. coccineous) durante las cuatro primeras semanas de la infección........72

Figura 4.4 - Virulencia de los aislados débilmente virulentos según su valor en la escala CIAT en plantas de judión ( $P$. coccineous) durante las cuatro primeras semanas de la infección........73

Figura 4. 5 - Media del valor medio de la escala CIAT de los aislados pertenecientes a cada uno de los grupos durante las cuatro primeras semanas de la infección.

Figura 4.6 - Virulencia de una selección de aislados altamente y débilmente virulentos en judión entre la cuarta y octava semanas tras la infección.

Figura 4.7 - Virulencia de una selección de aislados altamente y débilmente virulentos en judión

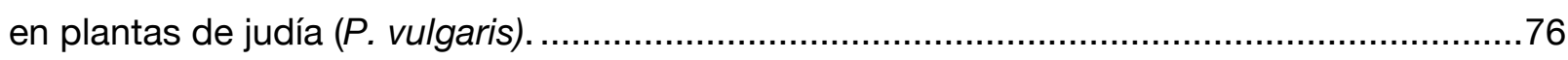

Figura 4.8 - Ensayo de virulencia en plantas de judía a las 2 semanas tras la infección ..............77

Figura 4. 9 - Amplificación mediante PCR de las regiones mating-type. 
Figura 4. 10 - Modelos de patrones de bandas de digestiones del IGS

Figura 4. 11 - Digestión con la enzima Xhol de tres aislados control y los aislados SP22, SP23,

SP26, SP30, SP29, SP34, SP36, SP37, SP33, SP31, SP35 y SP32

Figura 4.12 - Sondas usadas en las hibridaciones tipo Southern

Figura 4. 13 - Hibridaciones Southern de ADN digerido con HindIII de estirpes de F. oxysporum aisladas en judión e hibridado con la sonda M18B-M19A.

Figura 4. 14 - Hibridaciones Southern de ADN digerido con HindIIl de estirpes de F. oxysporum aisladas en judión e hibridada con las sondas B5-M17A y B310-A280.

Figura 4. 15 - Expresión relativa del gen ftf2 a lo largo del tiempo (en horas) en cultivos en medio líquido en una estirpe supervirulenta (SP13), altamente virulenta (SP1), débilmente virulenta (SP4) y no patógena (AB82)......

Figura 4. 16 - Expresión relativa del gen ftf2 a lo largo del tiempo (en horas) de crecimiento durante la infección en plantas de judía ( $P$. vulgaris) de una estirpe supervirulenta (SP13), altamente virulenta (SP1) y débilmente virulenta (SP4).

Figura 4. 17 Expresión relativa del gen ftf1 a lo largo del tiempo (en horas) en cultivos en medio líquido de estirpes supervirulenta (SP13) y áltamente virulenta (SP1).

Figura 4. 18 - Expresión relativa del gen ftf1 a lo largo del tiempo (en horas) de crecimiento durante la infección de plantas de judía ( $P$. vulgaris) de una estirpe supervirulenta (SP13) y áltamente virulenta (SP1).

Figura 4. 19 - Dendrograma de semejanzas de secuencias homólogas a ftf2 en varias especies de hongos...

Figura 4. 20 - ORFs situadas en las regiones flasnqueantes al gen ftf2 en varias especies de hongos

Figura 4. 21 - Dendrograma de semejanzas del fragmento B5-M17A de la región codificante homóloga a ftf1a, clonada y secuenciado en aislados de diferentes formas especiales de $F$. oxysporum .

Figura 4. 22 - Alineamiento del fragmento B5-M17A de las secuencias nucleotídicas de ftf1 en varias formas especiales de $F$. oxysporum

Figura 4. 23 - Hibridación tipo Southern con la sonda de la región codificante M18B-M19A de ADN digerido con HindIII de aislados de F. oxysporum pertenecientes a diferentes formas especiales.

Figura 4. 24 - Hibridación tipo Southern con la sonda del promotor B310-A280 de ADN digerido con HindIII de aislados de F. oxysporum pertenecientes a diferentes formas especiales.....100 Figura 4. 25 - Sitios HindIII en ftf1a y ftf2 de F. oxysporum f.sp. phaseoli y las distintas copias de ftf1 en F. oxysporum f.sp. lycopersici. 101

Figura 4. 26 - Matriz de puntos (dotplot) de similitud entre los supercontig 21, 18 y $41 \ldots \ldots \ldots \ldots . . . .102$

Figura 4. 27 - Matriz de puntos (dotplot) de similitud entre el supercontig 24 y 27. .102 
Figura 4. 28 - Árbol filogenético de la relación de las secuencias homologas ftf2 en las especies secuenciadas del género Fusarium, asi como la relación entre las copias homólogas a ftf1 de F. oxysporum f.sp. lycopersici y f.sp. phaseoli 104

Figura 4. 29 - Dendrograma de semejanzas entre las secuencias del promotor de los genes ftf1 y ftf2 en las formas especiales lycopersici y phaseoli. 106

Figura 4. 30 - Esquema de la comparación de las secuencias aminoacídicas deducidas de ftf1a y las 9 copias diferentes de $f t f 1$ y ftf2 en F. oxysporum lycopersicy .....................................108

Figura 4. 31 - Dendrograma de semejanzas de las secuencias aminoacídicas deducidas de ftf1a (F. oxysporum f.sp. phaseoli) y las copias de ftf1 y ftf2 en F. oxysporum f.sp. lycopersici ....109 Figura 4.32 - (Doble página) Inserción del transposón Impala y situación de los motivos de traducción en la secuencia nucletídica del promotor y comienzo de la región codificante...111

Figura 4. 33 - Esquema del plásmido binario pJJWA construido para el silenciamiento de los genes $f t f 1$ y ftf2

Figura 4. 34 - Amplificación mediante PCR en los transformantes silenciados del cassette de resistencia a la higromicina y del promotor ToxA y el primero de los fragmentos del gen diana

Figura 4. 35 - Expresión de ftf2 cuantificada mediante Real-time PCR con cebadores que hibridan fuera de la región usada en la construcción de silenciamiento de los transformantes silenciados 3.01, 3.03, 3.04, 3.08 y 3.15 respecto a la estirpe tipo silvestre SP4.

Figura 4. 36 - Expresión de ftf2 cuantificada mediante Real-time PCR mediante cebadores que hibridan fuera de la región usada en la construcción de silenciamiento de los transformantes silenciados 2.04 y 4.11 respecto a las estirpes silvestres SP1 y AB82.

Figura 4. 37 - Expresión de ftf2 cuantificada mediante Real-time PCR mediante cebadores que hibridan en la región usada en la construcción de silenciamiento (hairpin) en los transformantes 3.01 , 3.03, 3.04 y 3.08 y el tipo silvestre SP4; y su comparación con las mediciones anteriores con debadores que hibridan fuera de la región usada en la construcción de silenciamiento

Figura 4. 38 - Crecimiento en PDA y PDA+higromicina de una aislado silvestre de $F$. oxysporum f.sp. lycopersici, un transformante con un plásmido con resistencia a la higromicina (como control de la transformación) y un transformante con el plásmido pJJWA (W1, W2 o W4)...120

Figura 4. 39 - Crecimiento en medio PDA de la estirpe supervirulenta SP13 y sus transformantes (1.XX).

Figura 4. 40 - Crecimiento en medio PDA de la estirpe altamente virulenta SP1 y sus transformantes (2.XX). 122

Figura 4.41 - Tasa de esporulación (en esporas por mililitro) de varios transformantes frente a las estirpes silvestres de las que derivan, tras 3 días (azul) y 7 días (rojo) en cultivo líquido (PDB).125 
Figura 4. 42 - Crecimiento en medio PDA de la estirpe débilmente virulenta (SP4) y sus

transformantes (3.XX). 126

Figura 4. 43 - Crecimiento en medio PDA de la estirpe no patógena AB82 y sus transformantes $(4 . X X)$

Figura 4. 44 - Crecimiento a los 3 días de una selección de aislados silvestres y transformantes silenciados en medios con distintas fuentes de carbono y nitrógeno 128

Figura 4. 45 - Crecimiento a los 7 días de una selección de aislados silvestres y transformantes silenciados en medios con distintas fuentes de carbono y nitrógeno 129

Figura 4. 46 - Plantas de judía tras seis semanas infectadas con 3.15, 3.01, SP4 y SP4. .130

Figura 4. 47 - Vista general de un ensayo de infección en plantas de judía tras dos semanas infectadas con aislados débilmente virulentos.

Figura 4. 48 - Progreso de la enfermedad, cuantificado mediante índice CIAT, en planta de judía de la variedad Blanca-Riñon inoculadas con esporas de la estirpe silvestre FOP-SP13 y varios transformantes silenciados.

Figura 4. 49 - Progreso de la enfermedad, cuantificado mediante índice CIAT, en planta de judía de la variedad Blanca-Riñon inoculadas con esporas de la estirpe silvestre FOP-SP01 y varios transformantes silenciados.

Figura 4.50 - Ensayo de virulencia a las 3 semanas tras la infección en una selección de estirpes silvestres y silenciadas. 135

Figura 4. 52 - Ensayo de virulencia en plantas de tomate infectadas con el transformante W4 y la estirpe silvestre Fol-Strain I tras tres semanas desde la infección.

Figura 4.51 - Ensayo de virulencia a las cinco semanas. Comparación de las estirpes tipo silvestre SP13 y SP01, con los transformantes silenciados que muestran una más clara reducción de la virulencia: 1.04 y 2.08 .

Figura 4.53 - Expresión relativa de los genes diferencialmente expresados entre el transformante 3.15 y el aislado silvestre SP4 tras 24 horas en cultivo. .137

Figura 4. 54 - Expresión relativa de los genes diferencialmente expresados entre el transformante 3.01 y el aislado silvestre SP 4 tras 48 horas en cultivo .138 
Tabla 3. 1 - Oligonucleótidos usados en este trabajo. 66

Tabla 3. 2 - Estirpes de F. oxysporum f.sp. phaseoli usadas en este trabajo.

Tabla 3. 3 - Estirpes de Fusarium oxysporum pertenecientes a distintas formas especiales usadas en este trabajo 68

Tabla 4. 1 - Virulencia cuantificada en la escala CIAT y el parámetro D.P.R. en judía....................77

Tabla 4. 2 - Virulencia cuantificada en la escala CIAT y el parámetro D.P.R. en judión .78

Tabla 4. 3 - Ensayos de compatibilidad vegetativa entre mutantes nit1 de las estirpes y mutantes nitN representativos y VCG resultantes

Tabla 4. 4 - Correspondencia entre el RFLP del IGS, grupo de virulencia y CVG para los $F$. oxysporum aislados de judión.....

Tabla 4. 5 - PCR cuantitativa en tiempo real específica para la detección de la expresión del gen ftf2 a distintos tiempos de crecimiento en cultivo líquido tras la inoculación. .88

Tabla 4. 6 - PCR cuantitativa en tiempo real específica para la detección de la expresión del gen ftf2 a distintos tiempos de crecimiento tras la infección en planta de judía .90

Tabla 4. 7 - PCR cuantitativa en tiempo real específica para la detección de la expresión del gen ftf1 a distintos tiempos de crecimiento en cultivo líquido tras la inoculación. .93

Tabla 4. 8 - PCR cuantitativa en tiempo real específica para la detección de la expresión del gen ftf1 a distintos tiempos de crecimiento tras la infección en planta de judía

Tabla 4. 9 - Homologías observada entre las distintas regiones del genoma de F. oxysporum f.sp. lycopersici (presuntas copias de ftf1) y la copia ftf1a de F. oxyporum f.sp. phaseoli, según se use en la comparación la secuencia completa, la región codificante o la región promotora 103

Tabla 4. 10 - Homología entre las copias de ftf1 y ftf2 en F. oxysporum f.sp. lycopersicy ...........105

Tabla 4. 11 - Longitud (en aminoácidos) de las posibles secuencias aminoacídicas deducidas de cada copia de los genes ftf1 y ftf2 en F. oxysporum f.sp. lycopersici, en función del codón de inicio considerado 109

Tabla 4. 12 - Expresión de ftf2 cuantificada mediante Real-time PCR mediante cebadores que hibridan fuera de la región usada en la construcción de silenciamiento

Tabla 4. 13 - Expresión de ftf2 cuantificada mediante Real-time PCR mediante cebadores que hibridan en la región usada en la construcción de silenciamiento (hairpin) .

Tabla 4. 14 - Valores de virulencia de los aislados supervirulentos, medidos en la escala CIAT y vía el parámetro D.P.R. en judía. .132

Tabla 4. 15 - Valores de virulencia de los aislados altamente virulentos, medidos en la escala CIAT y vía el parámetro D.P.R. en judía

Tabla 4. 16 - ORFs encontrados en la secuenciación de la genoteca de expresión diferencial ..139 

This thesis expects to continue the study of the ftf1 and ftf2 transcription factors in the pathogenic fungus $F$. oxysporum. In order to accomplish this task we aimed at the following specific objectives: a) characterization of virulence in new isolates of $F$. oxysporum f.sp. phaseoli, b) analysis of ftf1 and ftf2 expression, c) new insights in the genomic architecture of the copies of both genes in the genus Fusarium and other plant pathogens, d) characterization of transformants with ftf1 and ftf2 altered expression, and e) identification of genes regulated by ftf1 and ftf2 as a way to know about the function of both genes.

Our group has isolated $F$. oxysporum in common bean $(P$. vulgaris) and runner bean $(P$. coccineous) fields in the region of El Barco de Ávila (Ávila, Spain). The comparison of these spanish isolates with pathogenic $F$. oxysporum f.sp. phaseoli isolates from other geographic origin allowed the identification of three new VCG called 0166, 0167 and 0168 (Alves-Santos et al., 1999), which together constitute a new race of the pathogen

These pathogenic isolates can be divided in two groups, highly virulent and weakly virulent, on the basis of the virulence differences as determined by using the CIAT scale (PastorCorrales \& Abawi, 1987) in inoculation assays performed on spanish varieties of common bean: (Alves-Santos et al., 2002a).

In a previous study (Alves-Santos et al., 2002b) we isolated a sequence characterized amplified region (SCAR) marker, named SCAR-B310A280, that enables the in planta detection of highly virulent $F$. oxysporum f.sp. phaseoli strains as early as 5 hours post-infection. This SCAR marker contains an ORF with a $\mathrm{Zn}(\mathrm{II})_{2} \mathrm{Cys}_{6}$ binuclear cluster DNA-binding domain and a medium homology region or domain (MHR), both domains are fungal specific and characteristic of transcription factors. The gene was called ftf1 (Fusarium transcription factor 1) (Ramos et al., 2007), and it can be found not only in forma especialis phaseoli, but also in thirteen different formae speciales such as betae, pisi, lycopersici, cubense, etc. (Nuñez-Corcuera, 2004; Ramos et al., 2007).

Expression of the gene ftf1 could not be detected in mycelium growing in liquid media neither by Northern hybridizations nor RT-PCR (Reverse transcription PCR). However, in planta transcription of $f t f 1$ is increased about 24 hours after plant inoculation, as detected by Real-time RT-PCR. This result suggests that ftf1 has a role in the establishment of the fungus within the plant and/or the progress of the disease (Ramos et al. 2007). 
Multiple copies of $f t f 1$ are present in highly virulent strains of $F$. oxysporum f.sp. phaseoli as it could be demonstrated by Southern hybridizations carried out with probes from the ftf1 coding region (M18B-M19A) and the ftf1 promoter (B310-A280) Gene disruption experiments showed that two or more of the copies are transcriptionally active. (Ramos et al. 2007). These Southern hybridizations also showed a faint hybridization that can also be found in DNA from weakly virulent and non-pathogenic strains. A new gene highly homologous (83\%) to the ftf1 coding region was isolated and designated ftf2 (Fusarium transcription factor 2). By contrast, ftf1 and $f t f 2$ promoter homology is only about $65 \%$, which suggests that there may be a different regulation of both genes. Also, $f t f 2$ homologues were found in a wide range of filamentous fungi (Ramos, 2005).

Virulence of twenty-five $F$. oxysporum strains isolated from $P$. coccineous was characterized by greenhouse inoculation assays performed on common bean and runner bean plants. Inoculation of runner bean plants, showed that nine isolates display a new virulence phenotype characterized by CIAT scale values close to 9 two weeks after infection. They were designated supervirulent strains. Nine isolates presented a lower virulence phenotype than the previous group, with CIAT scale values over 7 after four weeks, similar results to those displayed by the common bean highly virulent group. The third group showed CIAT scale ratings below 7 four weeks after infection. Similar values than showed in common bean by the weakly virulent group, so they were designated weakly virulent too. CIAT scale ratings did not increase when inoculates plants were allowed to grow for up to eight weeks. The statistical significance of $F$. oxysporum f.sp. phaseoli virulence groups in runner bean was verified by D.P.R. (Disease Progression Rate) quantification and an Analysis of variance (One-way ANOVA). Supervirulent isolates had a D.P.R. over 8, highly virulent isolates had a D.P.R. between 8 and 7, and weakly virulent isolates had a D.P.R. below 6.5. Also, virulence of strains isolated in runner beans was tested in inoculations assays on common bean plants. In this case there was no difference between the supervirulent and the highly virulent group.

Four new vegetative compatibility groups (VCG) were found among the $F$. oxysporum strains isolated from runner bean plants. VCG 0169 includes most of the isolates, VCG 01610 includes two isolates and VCGs 01611 and 01612 are composed by only one isolate each. All isolates have the same sexual idiomorph or mating-type MAT1-2. RFLP analysis of the ribosomal DNA intergenic spacer (IGS) showed two polymorphic patterns previously described as IGS-A haplotype and IGS-B2 haplotype. (Alves-Santos et al., 1999). There is no correlation between virulence groups, VCGs and IGS haplotypes. 
The number of copies of the ftf1 gene present in the genome of isolates characterized in these work was analyzed by Southern hybridization using probes obtained from the $f t f 1$ promoter and the 5' coding region. Supervirulent strains showed one more band than the highly virulent, indicating the presence of another polymorphic copy of the ftf1 gene. However, some isolates classified in infection essays in runner bean like highly virulent, and even an isolated classified like weakly virulent in runner bean, also showed this additional band. All strains isolated from runner bean have several copies of the ftf1 gene, confirming that this gene is exclusive of highly aggressive (highly virulent and supervirulent) strains.

The expression of gene ftf2 was quantified in a representative strain of each described virulence group, RNA samples were obtained from mycelium grown in liquid medium (PDB) and from inoculated common bean plants. The expression pattern of $f t f 2$ along time is slightly different for each strain analyzed, but the differences do not account for clear up or down regulation. Either expression was relatively stable since the earlier sampling times or increased until a stable expression pattern. No correlation of expression patterns with strain virulence could be found.

The expression pattern of gene ftf2 during the infection of common bean plants was similar to that found during growth in liquid cultures: quite stable with a small increase in time and without differences among strains with different virulence. This stability in the gene expression is characteristic of constitutive genes involved in fundamental functions. Also, the lack of up or down regulation in supervirulent or highly virulent strains suggests the lack of a role for ftf2 in virulence.

The expression of gene $f t f 1$ was measured in the supervirulent strains characterized in this work, and results were compared with those formerly obtained in highly virulent strains (Ramos, 2005; Ramos et al., 2007). The expression of ftf1 during axenic growth in liquid culture is mainly invariable along time and similar in a supervirulent strain and a highly virulent strain. Previous studies have shown a dramatic increase in ftf1 expression 24 hours after infection in common bean plants inoculated with highly virulent strains (Ramos et al., 2007). In this work, using another Real-time PCR measuring procedure, we have detected a 15-fold increase for the supervirulent strain (SP13) and a 11-fold increase for the highly virulent strain (SP1). The difference may suggest a functional relationship between the number of $f t f 1$ functional copies, strain virulence and $f t f 1$ expression maximum. The dramatic increase in the ftf1 expression during infection but not during axenic growth strongly supports a relevant role for ftf1 in the early infection stages.

The search for ftf2 homologues reveal unique sequences in the genomes of both pathogenic fungi (as Magnaporthe grise and Aspergillus nidulans) and non-pathogenic fungi (as 
Neurospora crassa and Podospora anserina). This distribution suggests gene ftf2 is not involved in pathogenicity. There is a ftf2 homologous sequence in the genomes of $F$. oxysporum, $F$. graminearum and $F$. verticilloides, and the ftf2 flanking regions are conserved in the three species.

When regions of the sequence that are highly homologous between $\mathrm{ftf1}$ and ftf2 are used as probes in Blast searches against the genome sequences of Fusarium oxysporum, Fusarium verticillioides and Fusarium graminearum, a single sequence can be detected in the last two genomes, and this is ftf2. On the contrary, the sequenced genome of $F$. oxysporum f.sp. lycopersici strain 4287 reveals up to eleven sequences homologous to the $F$. oxysporum f.sp. phaseoli genes ftf1 and ftf2. The coding region is conserved among these eleven sequences (homology around 90\%) but the promoter region shows important differences because of the presence of the transposon Impala into the promoter of five of these ftf1 homologous sequences. Also, in these five copies the last aminoacids of the protein have been lost. These facts raise questions about the functionality of these copies.

We have used Southern hybridizations to analyze the number of $f t f 1$ polymorphic copies in different $F$. oxysporum formae speciales. The number of $f t f 1$ copies is highly variable among formae speciales and even among isolates of the same forma specialis. In f.sp. lycopersici, we have found isolates showing 4 or $5 \mathrm{ftf1}$ copies (as happened in f.sp. phaseoli). In general, the number of polymorphic copies is lower than the number of copies found in the genome analysis.

Also, a fragment from the beginning of the $f t f 2$ coding region was amplified from DNA samples of representative strains of different $F$. oxysporum formae especiales. Isolates from different formae especiales showed sequences mainly similar. For example, among f.sp. phaseoli and lycopersici isolates; or among betae, nicotiana and pini isolates. The sequenced f.sp. phaseoli ftf1 copy (ftf1a) is more similar to one of the f.sp. lycopersici ftf1 copies than this last to the rest of copies of the same strain.

The fact that several copies of gene ftf1 are functional rules out the use of gene knock-out procedures to obtain null mutants. In order to generate transformants with an attenuated or suppressed ftf1 and ftf2 expression, we designed a silencing construction (pJJWA) base on a binary plasmid in which two copies of the sequence amplified from a completely conserved region in ftf1 and ftf2, but arranged in opposite senses, have been introduced. To facilitate the loop formation a spacer, typically an intron, is usually included between the two sequences. Our silencing construction used a region of the target gene, only present in one of the amplicons, as spacer, with efficient results. Because of the high homology of the target region in genes ftf1 and $f t f 2$, we expected to silence both genes at the same time. 
Transformants were obtained from four wild-type strains representing the different virulence groups: supervirulent (SP13), highly virulent (SP1) and weakly virulent (SP4) strains, and also from a non-pathogenic strain (AB82). Transformants carrying the silencing construction cloned in plasmid pJJWA showed a reduction in the growth rate, rate of sporulation and, in some cases, also in the virulence. However, when we measured the ftf2 expression in the silenced transformants by Real-time PCR we did not always observe a reduction; on the contrary, some transformants showed increased levels of some regions of the transcript. Our hypothesis is that this is the consequence of an amplification of the silencing in a similar way than had been described in plants: Aberrant RNAs may be the template to produce new dsRNA, that later would generate secondary siRNA.

The reduction in the growth rate observed in axenic growth cultures (PDA) is observed in F. oxysporum f.sp. phaseoli and f.sp. lycopersici transformants. To rule out that the decreased growth rate was a consequence of the transformation process, we performed transformations with the construction pS3, that contains the hygromycin resistance cassette (the hph gene under the control of the TrpC promoter and the Trp terminator from Aspergillus nidulans), but does not harbour the silencing target regions genes of the $\mathrm{ftf1}$ and ftf2 genes. In this case, no growth alterations were observed. In F. oxysporum f.sp. phaseoli, the growth rate reduction was observed in transformants obtained from the four wild-type strains.

Among transformants obtained with the same construction from the same wild type, the growth alterations display a gradient. Although they may be separated into two groups according to ANOVA tests. Some of the transformants showed clear significant alterations (strongly silenced transformants).

Growth rates were compared when some of the silenced transformants were cultured in media containing different carbon and nitrogen sources, and three different $\mathrm{pH}$. We observed differences after 3 days of growth that disappeared after 7 days. There were differences in the growth rates between the wild-type and silenced transformants strains in medium without glucose source, medium without nitrogen source and acid medium $(\mathrm{pH} 4)$, which suggest that silenced transformants are more sensible to nutrients starvation stress.

Also, sporulation rates were quantified after 3 and 7 days. Some transformants had an appreciable and significant reduction while other, though they displayed growth rate reduction, showed non significantly different sporulation rates, slightly smaller than the wild-type strains. 
To verify whether ftf2 silencing had effects in virulence, we carried out inoculation assays to compare the infection produced by weakly virulent strains FOP-SP4 (which do not have any ftf1 copy) with that produced by the corresponding silenced transformants. The CIAT scale ratings and D.P.R values were similar for all the strains, further supporting the hypothesis that $f t f 2$ has no role on virulence.

The effect of $f t f 1+f t f 2$ gene silencing was also analyzed in inoculation assays of common bean plants with a supervirulent strain (FOP-SP13), a highly virulent strain (FOP-SP1) and a sample of the corresponding silenced transformants. Six FOP-SP13-derived transformants that showed a significant reduction in growth rate were compared to FOP-SP13. Two of them (1.05 and 1.07), showed CIAT ratings similar to FOP-SP13 (CIAT ratings over 7 three weeks after inoculation). Two of them (1.06 and 1.09), showed CIAT ratings below to those induced by FOPSP13 (CIAT ratings under 6 three weeks after inoculation). Finally, the last two analyzed transformants (1.04 and 1.11) showed disease ratings clearly lower than those exhibited by FOPSP13 (CIAT ratings under 4 three weeks after inoculation). Four transformants obtained from the highly virulent strain FOP-SP1, that displayed a clear growth reduction, were also tested. Three of them (2.06, 2.07 and 2.20) did not show differences in the CIAT scale ratings with the wild-type strain FOP-SP1. They all showed CIAT scale values over 7 three weeks after inoculation. However, he fourth transformant (2.08) showed a clear reduction in virulence, with CIAT ratings under 5 three weeks after inoculation. The D.P.R. values were also lower than those obtained for the wild types, supporting the evidence of a virulence reduction in transformants 1.06, 1.09, 1.04, 1.11 and 2.04 , that would be induced by the silencing of gene $\mathrm{ftf1}$.

To investigate the possible function of the genes $\mathrm{ftf1}$ and $\mathrm{ftf2}$, we decided to identify genes regulated by ftf2. Using subtractive hybridization (SSH) we compared the RNAs transcribed in strain FOP-SP4 (a weakly virulent strain that only harbours the ftf2 gene) and the silenced transformant 3.01, in mycelia growth in axenic culture for 24 hours. We obtained 46 sequences out of 60 clones, from which, 18 were different ORFs. Among them, we selected 12 sequences, after a Blast search with the $F$. oxysporum genome, to undergo an expression study by Real-time PCR. To this purpose relative expressions of the 12 ORFs were compared in mycelia of the wildtype strain FOP-SP4 and the transformant 3.01 grown for 48 hours, and also in mycelia of the strain FOP-SP4 and the transformant 3.15 grown for 24 hours. All the putative genes supposedly regulated by ftf2 showed lower expression in the silenced transformants than in FOP-SP4.

It is worth to note the finding of genes, among those supposedly regulated by ftf2, involved in stress response, mitochondrial hypoxia and response to nutritional stress. Also, a Glutamine amidotransferase class-I coding ORF and a Piruvate descarboxilase with a tiamine 
binding domain (tiamine is a cofactor in the carbon pathway) coding ORF were found. As well, an Aspartyl protease highly homologous to $T$. harzianum SA76 CWDE was found. Finally, we found a Cyclin and two proteins without known conserved domains. One of the unknown ORFs is the most repeated sequence in the library.

In conclusion, we have characterized a new virulence group of isolates in $F$. oxysporum f.sp. phaseoli. These strains isolated from $P$. coccineous plants that showed symptoms of Fusarium wilt, have been characterized as supervirulent strains, in order to distinguish them from the previously described highly virulent and weakly virulent strains. All the supervirulent strains harbour an additional copy of the gene ftf1. However, some highly virulent and weakly virulent isolates also show this extra copy. Gene expression analysis carried out in bean plants inoculated with supervirulent strains show a higher upregulation of $f t f 1$ than that observed when inoculations were performed with highly virulent strains, which suggests that the extra ftf1 copy is functional.

Gene ftf2 is a transcription factor with an activator role, as all the putative genes identified in the substractive hybridization experiment showed a smaller expression in the ftf2 silenced transformants than in the weakly virulent wild-type strain FOP-SP4. Expression of gene ftf2 is mainly constant in time, both in mycelium grown in axenic cultures or in inoculated plants. This is a characteristic expression pattern of constitutive genes.

Gene ftf2 seems to be important for regular growth and sporulation, because silenced transformants show a significant reduction of the growth and sporulation rates. Some evidences seem to indicate that ftf2 could be involved in metabolism adaptation to nutrient stress conditions, because the higher growth differences between silenced transformants and the wildtype strains were found when they were grown in media with no carbon or nitrogen sources at shorter times. Also, two of the ORFs supposedly regulated by ftf2 are involved in stress response.

A possible role of ftf2 in pathogenicity or virulence may be ruled out by the following evidences: a) ftf2 is present in non-pathogenic F. oxysporum strains, and also in other nonpathogenic fungi; b) ftf2 expression is basically the same in strains of different virulence groups, an also when the strains are grown under axenic culture conditions or during plant infection; and c) silenced transformants did not show virulence variations when compared with the wild-type strains.

On the contrary, we have demonstrated gene $f t f 1$ is a virulence factor in $F$. oxysporum. Besides the expression results previously obtained, that we have confirmed and enlarged in this work, we have demonstrated that $f t f 1$ and $f t f 2$ silenced transformants show a clear virulence 
reduction, as shown in common bean plants inoculated with $F$. oxysporum f.sp. phaseoli strains and in tomato plants inoculated with F. oxysporum f.sp. lycopersici strains.

The gene $f t f 1$ is present in a variable number of copies, this number showing no correlation with the geographic origin of the considered strain nor the formae especiales. However, we have found some evidence in favour of a positive correlation between a higher copy number and ftf1 transcript level. There is a linkage between the ftf1 copies in F. oxysporum f.sp. phaseoli and transposon marsu, and between the ftf1 copies in the sequenced genome of strain 4287 of $F$. oxysporum f.sp. lycopersici and the transposon Impala. Homology between the ftf1 sequences analyzed in this work is not correlated with formae especiales, thus confirming that most formae speciales in F. oxysporum have a common origin. In this context, ftf1 copy homology could be an indicator of a common origin for isolates that have evolved adaptation to different hosts, or, alternatively, of gene transfer events. 
Esta tesis pretende continuar el estudio de los factores de transcripción ftf1 y ftf2 en el hongo patógeno $F$. oxysporum mediante la caracterización de la virulencia en nuevos aislados de F. oxysporum f.sp. phaseoli, el análisis de la expresión de ftf1 y ftf2, el análisis de la arquitectura genómica de las copias de ambos genes en el género Fusarium y en otros patógenos vegetales, la caracterización de transformantes con la expresión de ftf1 y ftf2 alterada, y la identificación de los genes regulados por ftf1 y ftf2.

Nuestro grupo ha aislado F. oxysporum en campos de judías (Phaseolus vulgaris L.) y judiones ( $P$. coccineous L.) de los alrededores de El Barco de Ávila (Ávila). La comparación de los aislados españoles con aislados patógenos de $F$. oxysporum f.sp. phaseoli de otras procedencias geográficas permitió asignar tres nuevos VCG denominados 0166, 0167 y 0168 (Alves-Santos et al., 1999).

Estos aislados patógenos pueden subdividirse en dos grupos según el grado de virulencia estimado conforme al índice de producción de enfermedad de la escala CIAT (Pastor-Corrales \& Abawi, 1987) en variedades de judía españolas: altamente virulentos y débilmente virulentos (Alves-Santos et al., 2002a).

La búsqueda de un SCAR (Sequence characterized amplified region) util para uso en diagnóstico mediante RAPD (Random amplified polymorphic DNA), permitió detectar un fragmento de ADN (B310-A280) específico de los aislados patógenos altamente virulentos (AlvesSantos et al., 2002b). El análisis de esta secuencia reveló la existencia de un ORF que permitió aislar un nuevo gen. El nuevo gen incluye un dominio de unión al ADN (DBD) dedo de zinc binuclear o Zn(II)2Cys6 y un dominio o región de mediana homología (MHR) ambos específicos de hongos y característicos de factores de transcripción. El gen se denominó ftf1 (Fusarium transcription factor 1) (Ramos et al., 2007). El gen ftf1 está presente en las formas especiales betae, pisi, lycopersici y cubense. con una homología del 95\% entre ellas (Nuñez-Corcuera, 2004).

No se pudo detectar expresión de ftf1 en cultivo líquido mediante hibridizaciones tipo northern ni RT-PCR (Reverse transcription PCR). Sin embargo, el estudio mediante PCR cuantitativa en tiempo real (Real-time PCR) de la expresión de ftf1 en plantas de judía infectadas, reveló una clara inducción durante las primeras 48 horas, con un máximo a las 24 horas tras la infección en los aislados altamente virulentos, lo que sugiere un papel determinante de fftf1 en las primera etapas del proceso de infección (Ramos et al. 2007). 
Cuando se obtuvieron mutantes interrumpidos en ftf1 no se observaron variaciones en la virulencia en ensayos en planta de judía. Hibridaciones tipo Southern con sondas del gen marcador de la resistencia higromicina (hph) de la construcción de disrupción y de las regiones codificante (M18B-M19A) y promotora (B310-A280), demuestran la existencia de al menos cuatro copias de ftf1 en los aislados silvestres altamente virulentos de $F$. oxysporum f.sp. phaseoli, y la correcta inserción del gen hph en una de las copias de ftf1 en los transformantes interrumpidos. Pasó a denominarse la copia originalmente secuenciada como ftf1a. (Ramos et al., 2007). E número de copias de ftf1 hace imposible una estrategia de interrupción génica.

Estas hibridaciones tipo Southern mostraban una señal más tenue (que la de las cuatro copias de ftf1) que estaba presente también en estirpes débilmente virulentas y no patógenas de F. oxysporum f.sp. phaseoli. Su aislamiento permitió obtener un nuevo gen que muestra una alta homología (83 \%) en la región codificante con ftf1, por lo que se denominó ftf2 (Fusarium transcription factor 2). En cambio, la homología entre los promotores de ftf1 y ftf2 es de aproximadamente un $65 \%$, lo que sugiere una regulación diferente. Además, a diferencia de ftf1, se encontraron homólogos a ftf2 en un amplio rango de hongos filamentosos (Ramos, 2005).

La virulencia de veinticinco estirpes de $F$. oxysporum aisladas de $P$. coccineous fue caracterizada mediante ensayos en invernadero en plantas de judión y judía. En ensayos en judión, nueve de los aislados mostraban una virulencia mayor con valores en la escala CIAT cercanos a 9 tras dos semanas. Se les denominó supervirulentos. Nueve aislados mostraban una virulencia menor que el grupo anterior, con valores en la escala CIAT superiores a 7 tras cuatro semanas, lo que coincide con el grupo de altamente virulentos en judía, por lo que denominamos a este grupo como altamente virulentos. El tercer grupo está formado por siete aislados cuyos valores en la escala CIAT son inferiores a 7 tras cuatro semanas de infección, como el grupo caracterizado en judía como débilmente virulentos, por lo que los denominamos débilmente virulentos. Verificamos que la virulencia tras cuatro semanas no variaba cuando se prolongó el ensayo de infección hasta las 8 semanas. La significación estadística de los grupos de virulencia en judión fue verificada mediante el cálculo del índice D.P.R. (Disease Progresion rate) y un Análisis de la Varianza (One-way ANOVA). Los aislados supervirulentos presentan un D.P.R. mayor de 8 , los aislados altamente virulentos entre 7 y 8 , y los aislados debilmente virulentos inferior a 6,5. También se comprobó la virulencia de las estirpes aisladas en judión en ensayos de infección en judía. Aislados pertenecientes a diferentes grupos de virulencia en judión se comportaron como altamente virulentos en judía. 
Los aislados de F. oxysporum obtenidos de judión forman cuatro nuevos grupos de compatibilidad vegetativa (VCG) de la forma especial phaseoli. El VCG 0169 aglutina la mayor parte de los aislados, el VCG 01610 está formado por dos aislados y los VCGs 01611 y 01612 por un único aislado cada uno de ellos. Todos ellos pertenecen al mismo idiomorfo sexual o matingtype MAT1-2. El análisis mediante RFLP del espaciador intergénico (IGS) del ADN ribosómico permite incluirlos dentro de los perfiles conocidos como A y B2, al que pertenecen otras estirpes de la misma forma especial aisladas en judía. No se observa relación entre los grupos de virulencia, compatibilidad vegetativa y RFLP del IGS.

Mediante hibridaciones Southern con sondas del promotor y región codificante de ftf1 caracterizamos el número de copias de ftf1 en las nuevas estirpes. Todos los aislados supervirulentos mostraron una banda más que el resto de los aislados, lo que sugiere una copia adicional de ftf1. Sin embargo, algunos aislados clasificados en ensayos de virulencia en judión como altamente virulentos, e incluso un aislado clasificado como débilmente virulento, mostraban también esta banda adicional. Todas las estirpes aisladas en judión mostraban presencia de ftf1, confirmando la distribución irregular exclusiva de aislados altamente virulentos (y supervirulentos) de este gen.

Se cuantificó la expresión del gen ftf2 de un representante de cada uno de los grupos de virulencia descritos, tanto durante el crecimiento en medio de cultivo líquido como durante la infección en plantas de judía. El perfil de expresión de ftf2 en cultivo líquido es característico de cada aislado y no presenta picos o valles importantes. Se mantiene desde el inicio estable en el tiempo o parte desde niveles bajos y crece rápidamente hasta estabilizarse. A tiempos mayores muestra un ligero incremento de la expresión. Los valores de expresión son similares independientemente de la virulencia del aislado.

Durante la infección de judía, la expresión del gen ftf2 es muy parecida a la mostrada en cultivo liquido: Bastante estable con un ligero incremento en el tiempo y sin diferencias entre aislados con distinta virulencia. Esta estabilidad de la expresión es característica de genes constitutivos con funciones fundamentales. La similitud entre estirpes con distinta virulencia descarta la relación de ftf2 con la virulencia, y la semejanza de los perfiles en cultivo líquido y durante la infección en planta, con el proceso de infección.

También se cuantificó mediante Real-time PCR la expresión de ftf1 en los nuevos aislados supervirulentos y se comparó con la expresión de los aislados altamente virulentos. La expresión de ftf1 en cultivo líquido es prácticamente invariable en el tiempo y similar en la estirpe supervirulenta y altamente virulenta. El nivel de expresión se estabiliza a tiempos largos y es 
similar en los dos aislados. En cambio, como ya se había comprobado en estudios anteriores, en planta muestra un dramático incremento en las primeras 24 horas. Sin embargo, mientras en el aislado supervirulento el pico de expresión a las 24 horas alcanza 15 veces el nivel estable, en el aislado altamente virulento el pico es de 11 veces el nivel estable, lo que puede sugerir una relación entre el número de copias funcionales de ftf1, la virulencia y el pico de expresión del gen. Este claro incremento de la expresión que se presenta en planta pero no en cultivo líquido es una prueba importante a favor del un papel relevante de ftf1 en las etapas tempranas del proceso de infección.

Se han identificado homólogos de ftf2, también presentes en una única copia, en los genomas tanto de hongos patógenos (Magnaporthe grisea, Aspergillus niger) como no patógenos (Neurospora crassa, Podospora anserina). Esta distribución sugiere que ftf2 no es un gen implicado en patogenicidad. Existe una copia homóloga a ftf2 en los genomas de $F$. oxysporum, $F$. graminearum y $F$. verticilloides, y las regiones flanqueantes de ftf2 están conservadas en las tres especies.

En el genoma secuenciado de $F$. oxysporum, correspondiente a la estirpe 4287 de la forma especial lycopersici (FGSC 9935), existen 11 copias homólogas a los genes ftf1 y ftf2 identificados en $F$. oxysporum f.sp. phaseoli. La región codificante está conservada entre las distintas copias (entorno a un $90 \%$ de homología) pero la región promotora presenta diferencias importantes debido a la presencia del transposón Impala en el promotor de varias de las copias. Además, en estas copias se han perdido los últimos aminoácidos de la proteina. Estos hechos plantean interrogantes sobre la funcionalidad de estas copias.

Mediante hibridaciones tipo Southern cuantificamos el número de copias polimórficas en varias formas especiales de $F$. oxysporum, que resultó ser altamente variable entre las diferentes formas especiales y aún entre aislados de la misma forma especial. En el caso de la forma especial lycopersici, encontramos aislados con 4 o 5 copias de ftf1 (como sucedía en la forma especial phaseoli) pero el número de bandas (copias con distinto patrón de restricción) es significativamente menor que el número de copias encontradas en el genoma secuenciado.

También amplificamos el comienzo de la región codificante de una de las copias de ftf1 en varias formas especiales de $F$. oxysporum. Aislados de distintas formas especiales mostraban secuencias prácticamente iguales entre si. Este es el caso entre las formas especiales phaseoli y lycopersici; y entre betae, nicotiana y pini. La copia de ftf1 secuenciada en la forma especial phaseoli (ftf1a) es más parecida a una de las copias de la forma especial lycopersici que esta última al resto de copias del mismo aislado. 
Para generar transformantes con la expresión de ftf1 y ftf2 eliminada o atenuada, diseñamos una construcción de silenciamiento que se basa en un plásmido binario en el que se han introducido dos copias homólogas amplificadas de una región completamente conservada en ftf1 y ftf2, dispuestas en sentidos contrarios. Para facilitar la formación del bucle se incluye un espaciador entre las mismas, típicamente un intrón. Nuestra construcción usa una región del propio gen diana presente en solo uno de los amplicones como espaciador, obteniendo resultados similares a cuando se utiliza un intrón. Debido a la gran homología de la región elegida, esperábamos silenciar ambos genes al tiempo.

Obtuvimos transformantes a partir de cuatro estirpes del tipo silvestre representantes de los distintos grupos de virulencia: supervirulentos (FOP-SP13), altamente virulentos (FOP-SP01 y, débilmente virulentos (FOP-SP04), asi como una estirpe no patógena (AB82). Los transformantes que portan la construcción de silenciamiento muestran alteración en el crecimiento, la esporulación y, en algunos casos, de la virulencia. Sin embargo, cuando medimos la expresión de ftf2 en los transformantes silenciados no observamos una reducción de la misma, si no por el contrario, un incremento en el tiempo de la presencia de transcrito de ftf2. Nuestra hipótesis es que nos encontramos ante un proceso de amplificación del silenciamiento similar al observado en plantas, en el que ARN aberrante sirve de molde para la producción de nuevo dsRNA y este en siRNA secundario.

La reducción de la tasa de crecimiento en medio rico (PDA) se observa en transformantes de F. oxysporum f.sp. phaseoli y f.sp. lycopersici. Para descartar que se debiera al proceso de transformación en si mismo, transformamos al mismo tiempo con otra construcción análoga (pS3) que portaba el cassete de resistencia a la higromicina pero no contiene las regiones de los genes ftf1 y ftf2 para el silenciamiento. En este caso no se observaron alteraciones en el crecimiento. En la f.sp. phaseoli, la disminución de la tasa de crecimiento sucede en transformantes derivados de las cuatro estirpes silvestres.

Los transformantes derivados de una misma estirpe silvestre forman un gradiente en la alteración del crecimiento. Los transformantes silenciados forman dos grupos según su grado de alteración. La mayor parte de ellos no muestran diferencias estadísticamente significativas respecto del tipo silvestre. Sin embargo, algunos transformantes muestran una alteración claramente significativa. Estos transformantes son los que denominamos fuertemente silenciados. 
Los transformantes fueron cultivados en medios selectivos con diferentes fuentes de carbono, fuentes de nitrógeno y $\mathrm{pH}$. Observamos diferencias a los 3 días de crecimiento que desaparecen al cabo de 7 días. Existen diferencias entre las tasas de crecimiento de las estirpes del tipo silvestre y los transformantes silenciados en medio sin glucosa, en medio ácido $(\mathrm{pH} 4)$ y en medio sin nitrógeno, lo cual sugiere que los transformantes silenciados son más sensibles a estrés por carencia de nutrientes.

También se cuantificó la tasa de esporulación a los 3 y los 7 días. Algunos transformantes mostraban una reducción apreciable y significativa de la esporulación mientras que otros, aún mostrando reducción en el crecimiento, mostraban tasas de esporulación sólo ligeramente menores a la estirpe tipo silvestre y sin significación estadística.

Para comprobar si el silenciamiento de ftf2 tiene efecto sobre la virulencia realizamos un ensayo de infección comparando el aislado débilmente virulento FOP-SP4 (que no contiene ninguna copia de $\mathrm{ftf1}$ ) con sus transformantes silenciados. El desarrollo de la enfermedad fue similar en todas las plantas, obteniéndose índices CIAT y D.P.R. semejantes para la estirpe FOPSP4 y los correspondientes transformantes silenciados.

El efecto sobre la virulencia también se comprobó en aislados supervirulentos y altamente virulentos. Se comparó la virulencia de seis transformantes supervirulentos claramente afectados en el crecimiento con la estirpe silvestre FOP-SP13, de la cual derivan. Dos transformantes (1.05 y 1.07) no mostraron diferencias con el tipo silvestre y valores en la escala CIAT superiores a 7 tras tres semanas. Otros dos (1.06 y 1.09) mostraron un avance de la enfermedad más lento y un valor en la escala CIAT inferior a 6 tras tres semanas. Sin embargo, dos de los transformantes (1.04 y 1.11) mostraron una menor sintomatología desde la primera semana lo que conllevó valores en la escala CIAT entorno a 4 o inferiores en la tercera semana. En caso de los altamente virulentos, se probaron cuatro transformantes que mostraron una clara reducción del crecimiento. Tres de los transformantes $(2.06,2.07$ y 2.20) no mostraron diferencias de virulencia con la estirpe silvestre FOP-SP01, de la cual derivan. Todos ellos alcanzaban valores en la escala CIAT superiores a 7 tras tres semanas de infección. En cambio, uno de los transformantes (2.08) mostró un desarrollo de la enfermedad más lento con valores en la escala CIAT inferiores a 5 en la tercera semana y claras diferencias con la estirpe silvestre a tiempos mayores. El calculo del D.P.R. mostraba diferencias claras entre los distintos grupos propuestos, si bien un Análisis de la varianza no estimó significancias estadísticas.

A fin de indagar sobre la posible función de los genes ftf1 y ftf2, decidimos identificar genes regulados por ftf2. Para ello y mediante hibridación substractiva (SSH), comparamos los 
transcritos sintetizados tras 24 horas de crecimiento en cultivo líquido de la estirpe silvestre débilmente virulenta SP4, que no tiene el gen $f t f 1$, y el transformante silenciado derivado de ella 3.01. Secuenciamos 60 clones de los que obtuvimos 46 secuencias, 18 de las cuales correspondieron a ORFs diferentes. De ellas, seleccionamos 12 por comparación con el genoma de F. oxysporum, para someterlas a un estudio de la expresión mediante Real-time PCR, en el cual se compararon las expresiones relativas de estos presuntos genes en la estirpe FOP-SP4 y el transformante 3.01 a las 48 horas, y entre la estirpe FOP-SP4 y el transformante 3.15 a las 24 horas. Todos los presuntos genes regulados por ftf2 mostraron una menor expresión en los transformantes silenciados que en FOP-SP4.

Entre los genes identificados presuntamente regulados por ftf2, destaca la presencia de dos genes implicados en respuesta a estrés, uno a hipoxia mitocondrial y otro a estrés nutricional. También una glutamino aminotransferasa tipo 1 y una piruvato descarboxilasa con dominios de unión a la tiamina, que actúa como cofactor en la ruta del carbono. Además, un gen altamente homólogo a SIP5. Finalmente, una aspartil proteasa altamente homóloga a la CWDE SA76 de T. harzianum. Finalmente, encontramos una ciclina y dos proteínas sin dominios conservados conocidos. Uno de estos genes desconocidos es la ORF más repetida en la genoteca.

Concluimos que hemos caracterizado un nuevo grupo de virulencia formado por estirpes supervirulentas de F. oxysporum f.sp. phaseoli. Todas las estirpes supervirulentas contenían una copia adicional del gen ftf1. Sin embargo, algunas estirpes altamente y débilmente virulentas también mostraron esta copia extra. Los análisis de expresión llevados acabo en plantas de judía inoculadas con estirpes supervirulentas mostraron una mayor expresión de ftf1 que la observada en las plantas inoculadas con estirpes altamente virulentas, lo que sugiere que esta copia adicional es funcional.

El gen ftf2 es un factor de transcripción con un papel activador, ya que todos los genes presuntamente regulados por ftf2 mostraban una menor expresión en los transformantes silenciados en ftf2 que en la estirpe silvestre. La expresión de ftf2 es básicamente constante en el tiempo, tanto en crecimiento en cultivo en medio líquido como en plantas inoculadas. Este patrón de expresión es característico de genes constitutivos.

El gen ftf2 parece ser fundamental para el crecimiento y la esporulación, ya que los transformantes silenciados mostraron un reducción significativa de las tasas de crecimiento y esporulación. Algunas evidencias parecen indicar que ftf2 podría estar implicado en la adaptación metabólica a condiciones de estrés nutricional, debido a que las mayores diferencias de 
crecimiento entre los transformantes silenciados y las estirpes silvestres se encontraron a tiempos cortos en medios carentes de fuentes de carbono o nitrógeno. Además, dos de los genes supuestamente regulados por ftf2 están implicados en respuesta a estrés.

Un posible papel de ftf2 en patogenicidad o virulencia puede ser descartado por las siguientes evidencias: a) ftf2 está presente en estirpes no patógenas de $F$. oxysporum y en otros hongos no patógenos; b) la expresión de ftf2 es básicamente la misma en estirpes pertenecientes a distintos grupos de virulencia y cuando las estirpes son crecidas en cultivo líquido o durante la infección en planta; y c) los transformantes silenciados no mostraron variación en la virulencia en comparación a la de la estirpe silvestre.

El gen ftf1 es un factor de virulencia en F. oxysporum. Hemos confirmado que ftf1 se expresa dramáticamente durante la infección en plantas de judía. Además, los transformantes silenciados en ftf1 y ftf2 muestran una reducción de virulencia tanto en plantas de judía infectadas con F. oxysporum f.sp. phaseoli como en plantas de tomate infectadas con $F$. oxysporum f.sp. lycopersici.

El gen ftf1 está presente en un variable número de copias. El número de copias de ftf1 no tiene relación con el origen geográfico o la forma especial de la estirpe considerada. Sin embargo, hemos encontrado evidencias en favor de una relación positiva entre un mayor número de copias y el nivel de transcrito de ftf1. Existe una relación entre las copias de ftf1 en $F$. oxysporum f.sp. phaseoli y el transposon Marsu, así como entre las copias de ftf1 en el genoma secuenciado de la estirpe 4287 de F. oxysporum f.sp. lycopersici y el transposon Impala.

La homología entre las secuencias de ftf1 en las estirpes analizadas en este trabajo no se corresponde con las formas especiales a las que pertenecen, confirmando que muchas formas especiales tienen un origen común. El gen ftf1 podría ser un indicador del origen común de estirpes que han evolucionado adaptándose a distintos hospedadores y/o de eventos de transferencia de genes. 


\begin{tabular}{|c|c|}
\hline A & Adenina \\
\hline aa & Aminoácido \\
\hline ADN & Ácido desoxirribonucleico \\
\hline ADNc & ADN complementario \\
\hline ADNm & ADN mensajero \\
\hline ADNasa & Desoxirribonucleasa \\
\hline ARN & Ácido ribonucleico \\
\hline C & Citosina \\
\hline $\mathrm{CR}$ & Catabolite Represion, represión por catabolito \\
\hline \multirow[t]{2}{*}{ CDP-Star } & (2-Cloro-5-(4-metoxipiro(1,2-dioxietano-3,2'- \\
\hline & (5’cloro)triciclo[3.3.1.1.3.7]decan)-4il)-1-fenilfosfato disódico) \\
\hline dNTP & Deoxinucleótido-5'-trifosfato \\
\hline DEPC & Dietilpirocarbonato \\
\hline DMSO & Dimetil sulfóxido \\
\hline DIG & Digoxigenina-11-desoxiuridina-5'-trifosfato \\
\hline D.O. & Densidad óptica \\
\hline DTT & Ditiotreitol \\
\hline EDTA & Ácido etilendiaminoetetraacético \\
\hline et al. & Et alii, y colaboradores \\
\hline f. $s p$. & f. sp. forma specialis, forma especial \\
\hline FOP & Fusarium oxysporum f. sp. phaseoli \\
\hline g & Gramo \\
\hline g & Aceleración de la gravedad \\
\hline G & Guanidina \\
\hline GFP & Green Fluorescent Protein, proteína verde fluorescente \\
\hline $\mathrm{h}$ & Hora \\
\hline $\mathrm{Ha}$ & Hectárea \\
\hline hpi & Horas post infección \\
\hline IGS & Intergenic Spacer, región espaciadora intergénica \\
\hline IPTG & Isopropil $\beta$-D-tiogalactopiranósido \\
\hline IUPAC & International Union of Pure and Applied Chemistry \\
\hline $\mathrm{Kb} / \mathrm{Kbp}$ & Kilobases (1000 pares de bases) \\
\hline $\mathrm{Kg}$ & Kilogramo \\
\hline I & Litro \\
\hline $\mathrm{m}$ & Metro \\
\hline$M$ & Molar \\
\hline
\end{tabular}


MAPK

$\mathrm{M} / \mathrm{Mb} / \mathrm{Mbp}$

$\mu \mathrm{g}$

$\mathrm{ml}$

$\mu \mathrm{M}$

Min./min

$\mathrm{mm}$

$\mathrm{mM}$

MOPS

$\mathrm{N}$

ORF

$\mathrm{pb}$

PCR

PEG

pfu

pg

pm

Q-PCR

RAPD

$\mathrm{RH}$

ROS

r.p.m.

RT-PCR

$\mathrm{s}$

$S$

SAR

SCAR

SDS

$\mathrm{T}$

$T^{\mathrm{a}}$

TAE

Taq

$\mathrm{Tm}$

Tris
Mitogen Activated Protein Kinase, proteínas activadas por mitógeno

Megabases (1000 kilobases, 1.000.000 pares de bases)

Microgramo

Microlitro

Micromolar

Minuto

Milímetro

Milimolar

Ácido-3-morfolinopropanosulfónico

Normal

Open Reading Frame, marco de lectura abierta

Pares de bases

Polymerase Chain Reaction, reacción en cadena de la polimerasa

Polietilénglicol

Plaque former unit, unidad formadora de placa

Picogramos

Picomoles

Quantitative-PCR, PCR cuantitativa

Random amplified polymorphic DNA, ADN polimorfico amplificado al azar

Respuesta de hipersensibilidad

Reactive oxygen species, especies reactivas de oxígeno

Revoluciones por minuto

Retrotranscriptase- PCR, transcripción inversa

Segundo

Susceptibilidad

Systemic adquired resistence, resistencia sistémica adquirida

Sequence characterized amplified region, región amplificada, caracterizada y secuenciada

Dodecilsulfato Sódico

Timina

Temperatura

Tris acético EDTA

Thermus aquaticus

Melting temperature, temperatura de fusión

Tris (hidroximetil) aminometano 
U

UV

V

$\mathrm{v}$

VCG

$\mathrm{X}$-Gal
Uracilo

Ultravioleta

Voltio

Volumen

Vegetative Compatibility Group

5-Bromo-4-cloro-3-indol $\beta$-D-galactósido

CÓDIGO DE AMINOÁCIDOS (IUPAC)

Alanina Ala A

Arginina Arg $\mathrm{R}$

Asparragina Asn $\mathrm{N}$

Aspartato Asp D

Cisteína Cys C

Glutamina Gln Q

Glutamato Glu E

Glicina Gly G

Histidina $\mathrm{His} \mathrm{H}$

Isoleucina lle I
Leucina Leu L

Lisina Lys $\mathrm{K}$

Metionina Met M

Fenilalanina Phe F

Prolina Pro $\mathrm{P}$

Serina Ser $\mathrm{S}$

Treonina Thr $\mathrm{T}$

Triptófano Trp W

Tirosina Tyr $Y$

Valina Val V

Las estirpes patógenas presentes en nuestra colección están renombradas en la forma FOPSPXX, donde FOP equivale a Fusarium oxysporum f.sp. phaseoli, SP equivale a Spain, y XX es el número de estirpe. En este trabajo se usa SPXX como abreviación de FOP-SPXX. Por ejemplo, SP1 o SP01 como abreviación de FOP-SP01. Las estirpes no patógenas conservan su nombre original que hace referencia a su origen geográfico, como por ejemplo AB82. 



\section{Introducción}



El reino de los hongos agrupa aproximadamente un millón y medio de especies conocidas, tan diversas como levaduras unicelulares, patógenos de plantas y animales, o simbiontes de la raíz vegetal. Los hongos son eucariotas y están relacionados con los metazoos: hongos y animales divergieron hace unos 1.000 millones de años. Algunos hongos son levaduras unicelulares, pero la mayoría son organismos multicelulares filamentosos.

Desde un punto de vista funcional, los hongos patógenos de plantas 0 fitopatógenos constituyen un grupo relevante, que engloba tanto hongos inferiores como hongos superiores. Los hongos fitopatógenos han adquirido la capacidad para desarrollarse y colonizar plantas vivas, causando a menudo enfermedades en los hospedadores. Aquellos hongos patógenos que requieren de forma facultativa un hospedador se denominan saprófitos oportunistas o facultativos (cuando pueden vivir de forma saprofítica hasta que encuentran un hospedador) o parásitos oportunistas o facultativos, (cuando aprovechan los recursos nutricionales de la planta cuando está débil). Por el contrario, algunos hongos patógenos, denominados parásitos obligados, requieren de manera obligada un hospedador $y$ adoptan una forma de resistencia cuando no infectan.
Los hongos patógenos de plantas han sido tradicionalmente clasificados atendiendo a su estilo de vida. Los patógenos biotrofos (Puccina graminis, Passalora fulva, Ustilago maydis) presentan una dependencia total con el hospedador para completar su ciclo de vida, obteniendo nutrientes a partir de las células vivas mediante el desarrollo de estructuras de infección especializadas (Mendgen \& Hahn, 2002). Por el contrario, los patógenos necrotrofos (Phytopthora infectans, Botrytis cinerea, Cochliobolus heterostrophus) no poseen estructuras de infección especializadas y obtienen los nutrientes a partir de células muertas. Posteriormente se acuñó el término hemibiotrofo (Fusarium oxysporum, Magnaporthe grisea, Colletotrichum sp.) para considerar situaciones en los cuales el patógeno presenta una fase de biotrofo en la cual penetra dentro de la planta y se establece dentro del tejido del hospedador, para después pasar a una forma de vida necrotrofa (Perfect et al., 1999; Mendgen \& Hahn, 2002).

Adicionalmente, según el grado de especificidad con el hospedador se clasifican en monófagos, si presentan alta especificidad por un tipo concreto de hospedador (Alternaria alternata, $F$. oxysporum) o polífagos, si tienen baja especificidad con el hospedador (B. cinerea, Rhizoctonia sp., Pythium sp.) . 
En otros casos la resistencia obedece a un patrón multigénico. Así, para patógenos

Las plantas están bajo un constante ataque por los patógenos, y para impedirlo han desarrollado amplios mecanismos de defensa específicos contra los patógenos y éstos, por su parte, han evolucionado para superar las defensas del hospedador.

El modelo genético clásico para explicar la interacción entre los genotipos de la planta y el patógeno se denomina modelo "gen a gen" (Flor, 1956), y se fundamenta en que una planta resistente expresa un gen de resistencia (R), cuyo producto génico reconoce el producto de un gen de avirulencia (Avr) expresado en el patógeno, lo que induce una respuesta por parte de la planta. Los patógenos pueden mutar rápidamente, sus genes de avirulencia cambiar y así escapar a la respuesta de resistencia por parte de la planta. Como respuesta, muchos de los loci $R$ presentan un grado elevado de polimorfismo, resultando fenotipos resistentes (Sacristán \& GarcíaArenal, 2008).

Este modelo parece válido para muchas de las interacciones planta-hongo fitopatógeno (Cook, 1998) especialmente aquellas que muestran una elevada especificidad con el hospedador. Se trataría de casos extremos de coevolución específica (Sacristán \& García-Arenal, 2008), como los casos de Cladosporium fulvum y tomate (Jones et al., 1994; Dixon et al., 1998), Fusarium oxysporum f. sp. lycopersici raza 2 y tomate (Simons et al., 1998) o Melampsora lini y lino (Thrall et al., 2002). cuya virulencia radica en la liberación de toxinas, la compatibilidad o incompatibilidad depende no solo del reconocimiento del factor de virulencia, sino de la producción de toxinas por parte del patógeno y la producción o no de enzimas detoxificantes por parte de la planta (Dangl \& Jones, 2001).

\subsection{3 - El proceso de infección y defensas de la} planta

Los patógenos pueden entrar en la planta por la parte aérea (Pucciniales sp., B. cinerea, Colletrotrichum sp.) o a través de la raíz en el suelo (Fusarium sp., Verticillium sp., Sclerotinia sclerotiorum). La primera línea de defensa de la planta es la pared celular. La penetración del patógeno es posible por la digestión enzimática de las paredes de la planta, a través de aperturas como estomas abiertos o heridas en la superficie, gracias a la diferenciación de estructuras especializadas, como apresorios (M. grisea), haustorios (Erysiphe graminis) o rizoides (Rhizopus sp.).

Una vez que son atacadas, las plantas activan una serie de respuestas en el sitio donde se produjo la infección para crear un ambiente hostil para el desarrollo del patógeno. Primero, la planta forma estructuras de resistencia en la pared celular para bloquear físicamente el avance del hongo, como papilas de callosa y lignina, o sintetiza glicoproteínas de pared ricas en hidroxiprolina y proteínas inhibidoras de 
poligalacturonasas, para impedir la rotura de pectinas. Así mismo, la planta dispone de un amplio arsenal de compuestos antimicrobianos de amplio espectro, como las fitoalexinas, cuya producción se ha demostrado ligada a la infección (Thomma et al., 1999; Yang et al., 2004), o compuestos fenólicos, glicósidos fenólicos, lactonas insaturadas, compuestos azufrados, saponinas, glicósidos cianogénicos, glucosinolatos, dienos, etc.

La planta puede en pocas horas activar los mecanismos de muerte de las células y tejidos atacados, en lo que se conoce como Respuesta de Hipersensibilidad (RH) (Wei et al., 1992; Sacristán \& García-Arenal, 2008). Las células muertas contienen altas concentraciones de compuestos antimicrobianos.

Además, las plantas disponen de un sistema de Resistencia Sistémica Adquirida (SAR) (Hutcheson, 1998) que avisa de la existencia de un estrés a zonas que no han sufrido el ataque directo. Ello induce una respuesta de defensa que puede extenderse, no solo a los tejidos vecinos, si no incluso a otras plantas de la población.

Entre los mecanismos activados por estas respuestas se encuentra la producción de especies reactivas de oxígeno (ROS), moléculas muy oxidativas como $\mathrm{O}_{2} \circ \mathrm{H}_{2} \mathrm{O}_{2}$, que pueden formar enlaces con glicoproteínas de la pared o activar la síntesis de lignina por acción de las peroxidasas, inducir la muerte celular por daño oxidativo o actuar como señales para inducir genes de defensa. El óxido nítrico (NO) también parece ser señal de inducción de genes de defensa. Igualmente, la producción de NO potencia el papel de ROS por inhibición de catalasas y peroxidasas.

Otra respuesta es el incremento por parte de la planta de la entrada de nutrientes que le proporcionen energía para defenderse del patógeno (Biemelt \& Sonnewald, 2006). Sin embargo, muchos patógenos se valen de esta respuesta de la planta para incrementar la toma de nutrientes para su propio uso (Fotopoulos et al., 2003).

Durante la germinación de la espora y la penetración, los hongos fitopatógenos se valen de las reservas internas para obtener nutrientes. Una vez dentro, movilizan los mecanismos necesarios para obtener energía de la planta. Los hongos necrotrofos no forman estructuras específicas para la infección, si no que activan la producción de baterías de toxinas que producen la muerte rápida del hospedador. Los hongos biotrofos toman agua y nutrientes de la planta a través de estructuras de infección como los haustorios, o directamente viven en el apoplasto. Por lo general no matan a la planta si no que tratan de vivir de ella más tiempo. Los hongos hemibiotrofos presentan un comportamiento intermedio, carecen de estructuras especializadas pero han desarrollado mecanismos que les permiten obtener nutrientes del metabolismo del hospedador, y posteriormente ante un aumento de su demanda de nutrientes producen la muerte de la planta.

De igual forma que ocurre con la toma de carbohidratos de la planta, la adquisición 
de nitrógeno por parte del patógeno en ocasiones se basa en los diferentes compuestos producidos por la planta para defenderse. El ácido úrico funciona en la planta como secuestrador o "scavenger" de ROS (Bethke et al., 2006), en tanto que el hongo parece utilizar el ácido úrico para sus necesidades nutricionales.

Existen patógenos que son capaces de producir hormonas de la planta para crear un ambiente apropiado para el desarrollo del patógeno. Se ha observado que especies del género Fusarium que causan daños en el arroz producen la hormona giberelina durante la infección (Tudzynski, 2005). Otros patógenos producen etileno, bien porque resulta beneficioso para su desarrollo, bien porque actúa como un factor de virulencia interfiriendo con el etileno producido por la planta para la defensa (Guo \& Ecker, 2004).

Tanto en hongos biotrofos como en los necrotrofos y hemibiotrofos, la esporulación marca el final del ciclo de vida infectivo del patógeno. Estudios in vitro han mostrado que la esporulación puede desencadenarse por el agotamiento de las fuentes de carbono y nitrógeno. Algunos autores dividen el proceso de la infección en las fases de germinación, proliferación en fase biotrofa y/o necrotrofa y esporulación (Solomon et al., 2003).

\subsection{4 - Genes de patogenicidad y virulencia}

Se denominan genes o factores de patogenicidad a aquellos genes que son necesarios para el desarrollo de la enfermedad, pero no son esenciales para el patógeno durante su ciclo de vida en condiciones in vitro (Idnurm \& Howlett, 2001). La disrupción por cualquier técnica de un gen de patogenicidad resulta en una reducción (variación cuantitativa) o pérdida completa (variación cualitativa) de la sintomatología de la enfermedad.

Como el proceso de infección no es único, probablemente no existe un gen de patogenicidad transversal a todos los hongos fitopatógenos. Algunos autores clasifican los genes de patogenicidad en seis grupos, aunque algunos genes podrían incluirse en varias de estas divisiones: desarrollo de estructuras de infección, degradación de la pared celular, respuesta al ambiente del hospedador, toxinas fúngicas, cascada de señalización y "desconocidos" (Idnurm \& Howlett, 2001).

La base de datos de interacciones

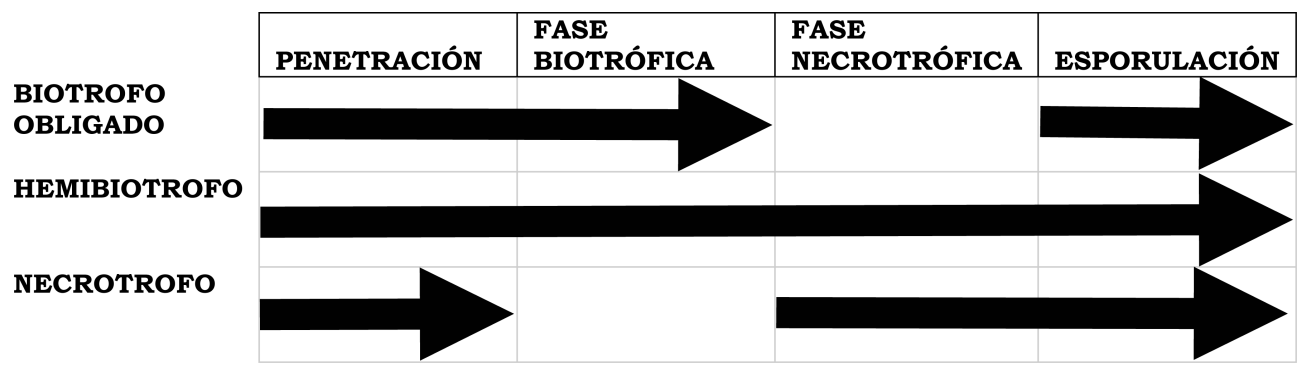

Figura 1. 1 - Fases del proceso de infección para los distintos tipos de patógeno según su ciclo de vida (García-Sánchez, 2007). 
planta-patógeno (PHI-base) contiene genes de patogenicidad cuya función ha sido demostrada experimentalmente. En la última revisión (Winnenburg et al., 2008) contenía 786 genes de patogenicidad descritos en hongos fitopatógenos.

Los genes de virulencia son un subgrupo de los genes de patogenicidad, con dos características diferenciadoras: están involucrados exclusivamente en virulencia pero no en ningún otro proceso y tienen una distribución filogenética limitada o "irregular" (van der Does \& Rep, 2007). Esta distribución parcial es fundamental para explicar el origen de los genes de virulencia. Como se ha visto en el apartado 1.1.2, algunas proteínas (denominadas de avirulencia) producidas por el patógeno durante la infección pueden ser reconocidas por los productos de los genes de resistencia $(R)$ de la planta. La presión selectiva sobre la población del patógeno favorece escapar del reconocimiento del hospedador, mientras que la selección en la población de la planta favorecerá el reconocimiento del patógeno. Ejemplos bien documentados son el gen Six1 de $F$. oxysporum (Rep et al., 2005) y en Melampsora lini (Dodds et al., 2004). Se produce una "carrera armamentísta" ("arms race") fundamentada en altas tasas de mutación de los factores de avirulencia del patógeno y las dianas del hospedador (Jones \& Dangl, 2006), como se ha observado en los genes de avirulencia de Cladosporium fulvum y el gen NIP1 de Rhynchosporium secalis (Rohe et al., 1995). En la misma línea, el análisis del genoma de $F$. graminearum revela un mayor polimorfismo en las regiones con genes implicados en la interacción plantapatógeno (Cuomo et al., 2007).

Otra alternativa que explica esta distribución irregular es la existencia de procesos de transferencia horizontal de genes (HGT) entre especies o grupos vegetativamente incompatibles (van der Does \& Rep, 2007) que avalaría la existencia de agrupamientos o clusters de genes de virulencia en algunos hongos patógenos como Colletotrichum gloesporioides ( $\mathrm{He}$ et al., 1998), Nectria haematococca (Han et al., 2001), Neocosmospora boniensis (Temporini \& VanEtten, 2004) y Alternaria alternata (Hatta et al., 2002).

Cuestión distinta es la aparición inicial de los genes de virulencia. Por un lado, se ha observado que existe una alta homología entre factores de virulencia en bacterias y hongos con el mismo hospedador (como la tomatinasa de Streptomyces spp. (Kers et al., 2005) y F. oxysporum (Ito et al., 2004), donde además muestra una distribución irregular. Por otro lado, algunas enzimas con roles en la infección tienen funciones metabólicas básicas en el patógeno, que sumado a que en hongos como N. Haematococca, $F$. oxysporum, A. Alternata, Cochliobolus spp. o Leptosphaeria maculans los genes de virulencia (y avirulencia) aparecen agrupados en regiones muy ricas en transposones, los cuales fomentarían eventos de recombinación, duplicación, etc. (Thon et al., 2006), explicando así la aparición de nuevos genes quiméricos. 
En especies con reproducción básicamente asexual, la existencia de transposones también explicaría la formación de agrupamientos (clusteres) de genes, por presión selectiva, ya que así se facilitaría su regulación, o bien permitiría la transferencia horizontal del grupo completo (van der Does \& Rep, 2007). En especies con altas tasas de reproducción sexual el agrupamiento de genes con funciones relacionadas, facilita su herencia conjunta y la regulación coordinada.

\subsection{5 - Silenciamiento mediado por RNA en hongos filamentosos}

"Quelling" (en hongos), cosupresión (en plantas) o interferencia por RNA (RNAi) (en animales) hacen referencia al mismo fenómeno de silenciamiento de genes a nivel post-transcripcional mediado por una maquinaria proteica relativamente conservada en eucariotas (Nakayashiki, 2005; Ghildiyal \& Zamore, 2009).

Según el tamaño de los fragmentos de ARN de doble cadena ( $d s R N A)$ que sirven de molde o guía a la maquinaria de silenciamiento, existen dos rutas independientes de silenciamiento mediado por RNA: siRNA ("small interfering RNA") y miRNA ("microRNA"). Ni en Neurospora sp., donde el silenciamento en hongos ha sido más estudiado, ni en otros hongos hay evidencias de que exista la maquinaria necesaria para el silenciamiento mediado por miRNA.

La interferencia de ARN (RNAi) es un proceso en el que ARN de doble cadena es

\section{Nowowowowow $\downarrow \quad$ dsRNA}
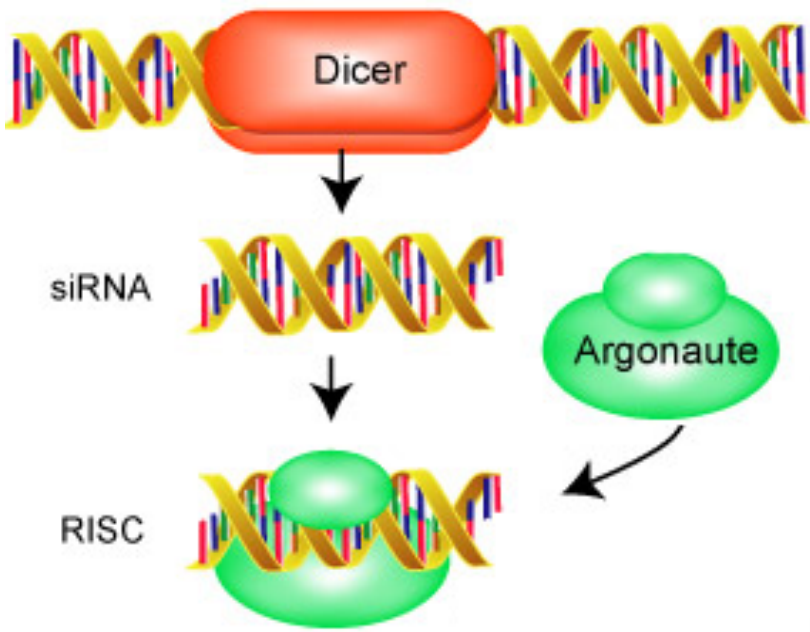

Argonaute
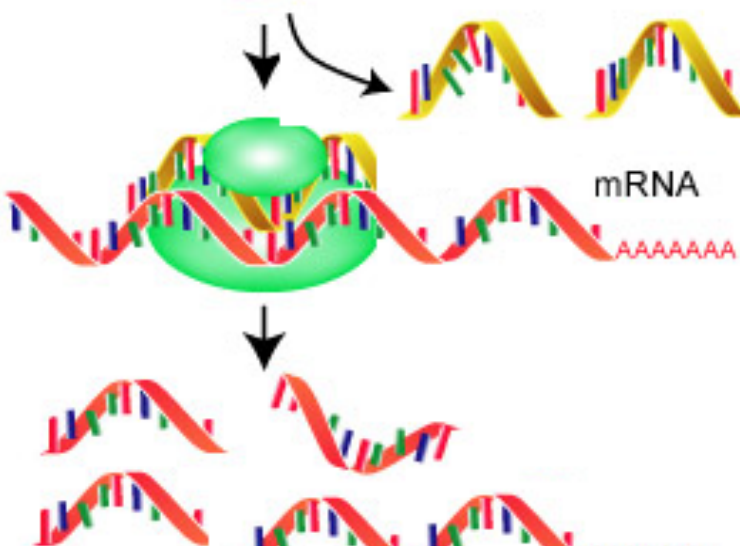

RNAiWeb.com

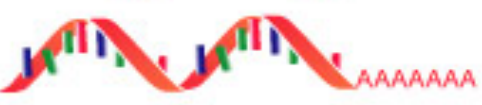

Figura 1. 2 - Ruta del silenciamiento mediado por siRNA. El ARN de doble cadena (dsRNA) producido por el plegamiento en horquilla del transcrito del plásmido, es escindido por el complejo Dicer en fragmentos menores que se integran junto al resto de proteínas para formar dentro del complejo ARN-proteico $R I S C$. La acción de las proteínas integrantes de RISC desaparean los fragmentos SiRNA que una vez desnaturalizados sirven de molde para romper el $A R N m$ del gen diana (RNAiweb.com). 
escindido por el complejo proteico Dicer en fragmentos del tipo siRNA, que inducen la acción del complejo RISC ("RNA-induced silencing complex") derivando en la degradación del ARN mensajero (ARNm o $m R N A$ ) homólogo, lo que conlleva una disminución o abolición de la expresión del gen de interés (Weld et al., 2006).

Se ha identificado la maquinaria proteica del silenciamiento en ascomicetos, basidiomicetos y zigomicetos, aunque está completamente ausente en ramas concretas como S. cerevisiae, Candida guilliermondii y C. Iusitanie, o el basidiomiceto U. maydis, y parcialmente ausente en otros como $C$. albicans (Nakayashiki et al., 2006). Se ha probado con éxito experimentalmente en ascomicetos (Hamada \& Spanu, 1998; Fitzgerald et al., 2004; Janus et al., 2007), basidiomicetos (Namekawa et al., 2005; Laurie et al., 2008) y zigomicetos (Nicolas et al., 2003).

La estrategia que conduce a un silenciamiento más eficiente y estable es la construcción de plásmidos que originan una horquilla de ARN de doble cadena ( $h p R N A$ "hairpin RNA") (Goldoni et al., 2004), habitualmente la formación del bucle es facilitada por la presencia de un intrón. Otra estrategia consiste en el uso de dos promotores dispuestos en sentidos contrarios, a continuación de los cuales se

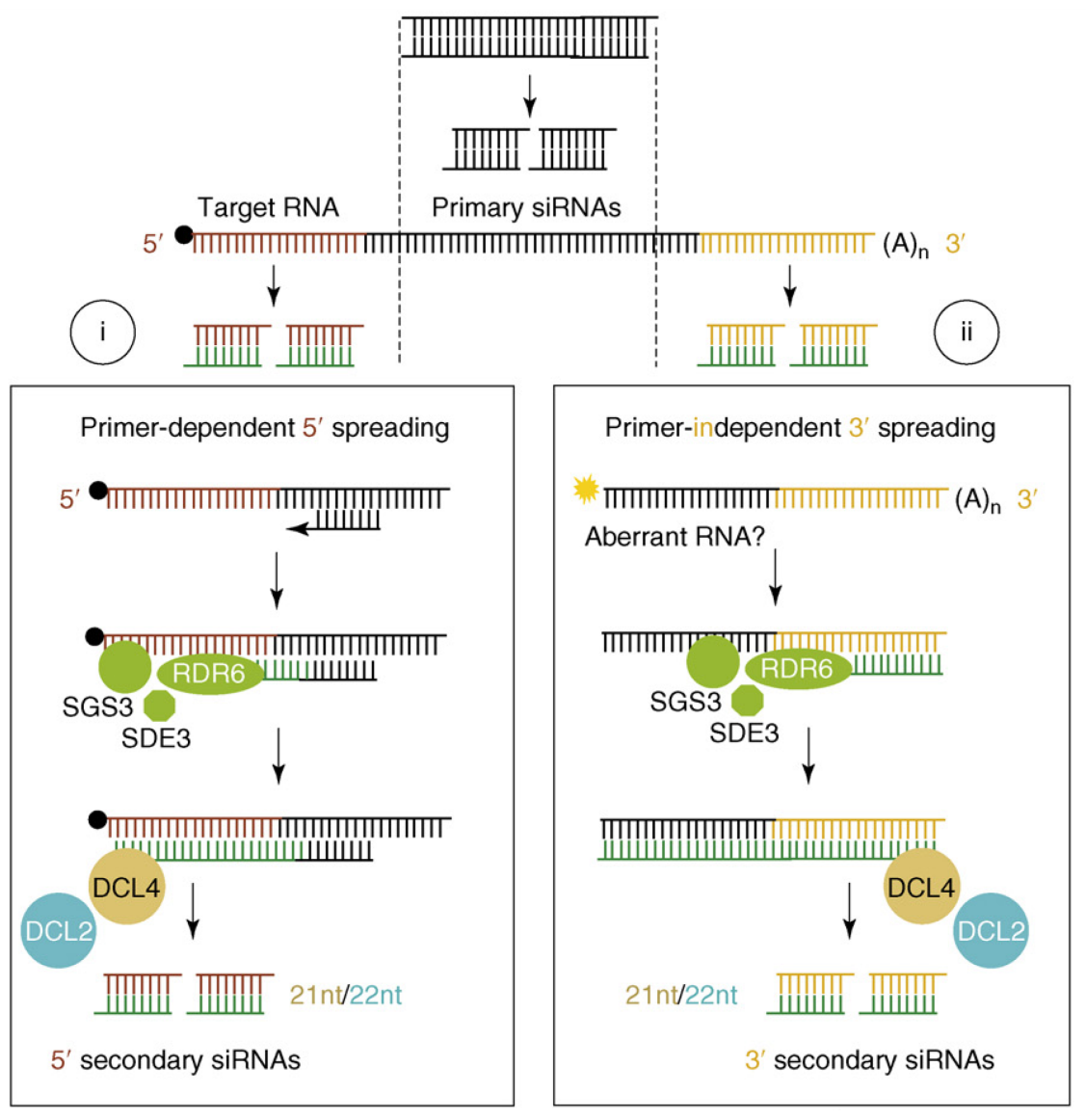

Figura 1. 3 - Amplificación del silenciamiento en plantas. La degradación de la región del $A R N m$ homóloga a los siRNA primarios libera las regiones flanqueantes a la misma, que por acción de proteinas $R d R P$ distinas según el sentido de duplicación (caso i ó ii), que sintetizan nuevas cadenas de ARNm que pueden ser degradas por complejos tipo Dicer en siRNA secundarios (Voinnet, 2008) 
insertan los fragmentos diana en el mismo sentido que el respectivo promotor. También se ha intentado la introducción directa de SiRNA o dsRNA en esporas y protoplastos, sin resultados concluyentes (Nakayashiki \& Nguyen, 2008).

En plantas, las ARN polimerasas ARNdependientes $(R d R P)$ pueden producir siRNA secundarios a partir de ARN aberrante, amplificando la respuesta de silenciamiento. Se ha observado que los fragmentos siRNA primarios, esto es, los escindidos del $A R N m$ original y liberados por el complejo RISC, pueden servir de molde para la acción de las RdRPs (como RDR6 en Arabidopsis sp.) para sintetizar nuevas plantillas de ARN de doble cadena, que por acción de nuevos complejos similares a Dicer (como DCL4 en Arabidopsis sp.) son escindidos en nuevos siRNAs (Ghildiyal \& Zamore, 2009). Al menos cinco proteinas $R d R P$ se han encontrado en $F$. graminearum, y en otros hongos en distinto número de copias (Nakayashiki et al., 2006).

El silenciamiento post-transcripcional (o knockdown) de un gen presenta ventajas y desventajas con respecto a la disrupción o interrupción génica (knockout). La principal ventaja es que la eficiencia de obtención de transformantes útiles es mucho mayor pues no es necesario un proceso de recombinación homóloga (Janus et al., 2007). Otra ventaja es que las secuencias del gen diana a clonar en el vector de silenciamiento pueden ser de pequeño tamaño (entorno a 500 bp) (Goldoni et al., 2004) y no tienen que ser completamente homólogas al gen diana del silenciamiento (Weld et al., 2006), lo que permite el silenciamiento de varios genes parecidos (Fitzgerald et al., 2004; Lacroix \& Spanu, 2009), familias génicas (Nguyen et al., 2008) o genes multicopia; pero puede ocasionar el silenciamiento colateral de genes parcialmente homólogos ("off-target effects") (Nakayashiki \& Nguyen, 2008). Sin embargo, el principal inconveniente es que el silenciamiento no es absoluto, y la cantidad de transcrito del gen es altamente variable, lo que permite el estudio de genes esenciales, pero también hace necesario un buen y amplio sistema de selección (Mouyna et al., 2004; Spiering et al., 2005). Este problema puede mitigarse mediante el silenciamiento simultaneo en la misma construcción de un segundo gen de control como el que codifica la GFP (Fitzgerald et al., 2004; Mouyna et al., 2004). 


\subsection{1- El genero Fusarium sp.}

El genero Fusarium, también conocido por sus teleomorfos Nectria y Gibberella, comprende un amplio y heterogéneo grupo de hongos patógenos de plantas con una gran variedad de hospedadores y estrategias infecciosas (Desjardins, 2003; Di Pietro et al., 2003; Goswami \& Kistler, 2004). Estos hongos viven en el suelo de forma saprofítica, alimentándose de sustratos orgánicos muertos, aunque muchos de ellos son capaces de reconocer e infectar a su planta hospedadora, convirtiéndose en patógenos de cultivos de gran importancia económica.

También algunas especies son capaces de producir micotoxinas en los alimentos utilizados para el consumo de animales y humano (Di Pietro et al., 2003). Recientemente se ha descrito a Fusarium como patógeno humano en pacientes inmunocomprometidos (Ortoneda et al., 2004). Muchas especies tienen un alto valor biotecnológico, utilizándose en el control biológico de plagas, o en la producción de metabolitos secundarios de gran interés (ciclosporina, giberelinas, etc.) (Desjardins et al., 1993).

El género presenta una clasificación compleja. Actualmente está incluido dentro del grupo de los Ascomicetos en la división Ascomicota, clase Sordariomycetes, orden Hipocreales, familia Necriaceae. En 1935
Wollenweber y Reinking dividieron el género en 11 secciones, 65 especies, 55 variedades y 22 formas especiales o formae speciales. Gerlach y Nirenberg (Gerlanch \& Niremberg, 1982), así como Nelson y colaboradores (Nelson et al., 1983) desarrollaron un sistema taxonómico basado también en características morfológicas. En 1990, Nelson distinguió 14 especies dentro del genero:

\begin{tabular}{|l|l|}
\multicolumn{1}{|c|}{ Especie } & \multicolumn{1}{c|}{ Sección } \\
\hline F. oxysporum & Elegans \\
\hline F. verticilloides & Liseola \\
\hline F. lateritium & Lateritium \\
\hline F. heterosporum & Discolor \\
\hline F. reticulatum & Discolor \\
\hline F. sambucinum & Discolor \\
\hline F. graminearum & Discolor \\
\hline F. equiseti & Gibbosum \\
\hline F. acuminatum & Gibbosum \\
\hline F. avenaceum & Roseum \\
\hline F. triticum & Sporotrichiella \\
\hline F. decemcellurare & Spicarioides \\
\hline F. episphaeria & Eupionnotes \\
\hline F. solani & Arthrosporiella \\
\hline
\end{tabular}

1.2.2 - Diversidad del género Fusarium sp.

La electroforesis en campo pulsado (CHEF) ha permitido visualizar el número y tamaño de los cromosomas. Se estimó que las especies del género presentaban entre 7 y 11 cromosomas con un tamaño que oscilaba entre las 0,6 y las 6,7 Mbp (Migueli et al., 
1993), se estimó el tamaño del genoma de Fusarium entre 27 y 29,9 Mb (Fekete et al., 1993). En F. solani se estudiaron diferentes formas especiales, identificando entre 5 y 12 cromosomas de entre 0,6 y $5,7 \mathrm{Mb}$, definiendo un patrón muy similar entre las distintas cepas de una misma forma especial. Sin embargo, la variabilidad en número y tamaño de cromosomas es grande, incluso para aislados pertenecientes a una misma forma especial (Alves-Santos et al., 1999).

Se ha avanzado en la sistemática mediante el uso de marcadores moleculares como las isoenzimas (Laday \& Szecsi, 2002), los RAPD ("random amplified polymorphism DNA") (Alves-Santos et al., 2002b), el análisis de las regiones intergénicas espaciadoras del ADN ribosómico (regiones IGS O ITS) mediante RFLP ("restriction fragment length polymorphism") (Alves-Santos et al., 1999), la comparación de secuencias (Guadet et al., 1989; Gordon \& Martyn, 1997) y, más recientemente los biochips (microarrays) de ADN (Lievens et al., 2003a; Lievens et al., 2003b).

Las técnica de análisis filogenético han permitido describir nuevas especies de Fusarium (O'Donnell et al., 2000; Tan \& Niessen, 2003). Se ha creado una base de datos (http://www.fusarium.cbio.psu.edu) con la región del factor de elongación de la traducción $1 \alpha$ (TEF, translation elongation factor) asociadas a especies caracterizadas morfológicamente para la identificación de nuevas especies de Fusarium (Geiser et al., 2004).
Dentro del programa del Broad Institute del MIT (Massachusetts Institute of Technology and Harvard): Broad Fungal Genome Inititative, se han secuenciado los genomas de F. graminearum, F. oxysporum y Fusarium verticillioides. El análisis de los genomas disponibles proporciona una valiosa información sobre genes que son importantes en la infección y colonización de la planta.

Estudios preliminares han mostrado que el $90 \%$ del genoma de F. oxysporum se alinea con el de $F$. verticilloides, y que la homología media de las regiones alineadas era de entorno al 90\%. Los aislados de $F$. oxysporum se agrupan dentro de la sección elegans, que se considera relacionada a la sección liseola, a la que pertenecen los aislados de $F$. vericilloides y $F$. fujikuroi (Guadet et al., 1989).

\subsection{3 - Variabilidad y genes sexuales}

La heterocariosis es la fusión de hifas sin cariogamia. los hongos que son haploides pueden obtener ciertos beneficios propios de la diploidía y si dos cepas son capaces de formar un heterocarionte vegetativo estable pertenecerán a un mismo grupo de compatibilidad vegetativa (GCV O VCG) (Puhalla, 1985).

Como en otros ascomicetes, la formación del heterocarionte en Fusarium está controlada por un grupo de loci, cuyos productos regulan la compatibilidad vegetativa o la incompatibilidad (Glass et al., 2000). Se han descrito al menos diez loci (het o vic) implicados (Leslie, 1993). Esto indica 
que la formación de un heterocarionte estable es posible cuando los alelos de estos loci son iguales en las dos cepas (Leach \& Yoder, 1983).

Pruebas basadas en la capacidad de mutantes nitrato reductasa de formar un heterocarionte y crecer sobre un medio con nitrato han sido utilizadas para clasificar aislados de Fusarium spp. en grupos de compatibilidad vegetativa (Puhalla, 1985; Alves-Santos et al., 2002a).

Algunos miembros del género Fusarium, como F. solani (Nectria haematococca), F. graminearum (Gibberella zeae) y F. verticillioides (Gibberella fujikuroi), pueden completar su ciclo sexual bajo condiciones naturales y de laboratorio (especies teleomórficas), mientras que otros como $F$. oxysporum no tienen ciclo sexual conocido (especies anamórficas).

Los genes responsables de la reproducción sexual, denominados de apareamiento o mating-type se han descrito en la mayoría de los ascomicetos como dos alelos de baja similitud en su secuencia, y a diferencia de las levaduras, no se han observado otras copias de estas secuencias en otros loci (Coppin et al., 1997).

Es destacable que, a pesar de su ciclo de vida asexual, $F$. oxysporum contenga los loci mating-type con los genes MAT1-1 o MAT1-2, que son muy similares a los genes de las especies heterotálicas como $G$. fujikuroi (Arie et al., 2000). Se ha descrito que los genes MAT se expresan y procesan correctamente en $F$. oxysporum, sugiriendo que debe haber otros mecanismos que regulen la reproducción sexual (Yun et al., 2000; Kerenyi et al., 2004).

\subsection{4 - Fusarium oxysporum}

Fusarium oxysporum es un hongo del suelo que incluye tanto estirpes no patógenas como patógenas de importancia económica. Todas ellas pueden vivir en el suelo de forma saprofítica alimentándose de materia orgánica muerta. Las estirpes no patógenas colonizan el córtex de la raíz sin causar síntomas de enfermedad ni producir daño a la planta. Las estirpes patógenas penetran por las raíces de las plantas hospedadoras colonizando los haces vasculares presentando los síntomas característicos de la enfermedad conocida como fusariosis vascular (Fusarium wilt).

La presencia de estirpes patógenas y saprófitas dentro de la misma especie facilita el análisis comparativo entre ambas para averiguar qué diferencias genéticas y moleculares son las que les confieren la capacidad patogénica.

F. oxysporum tiene una reproducción predominantemente (quizá exclusivamente)

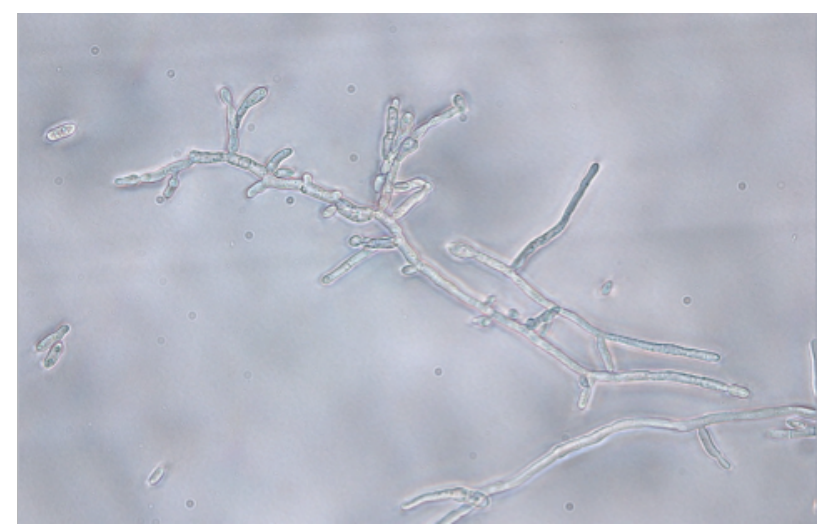

Figura 1. 4 - Desarrollo de hifas de $F$. oxysporum tras 36 horas de crecimiento en medio de cultivo líquido. 
asexual, por lo que algunos autores la definen como una colección de líneas clonales (Michielse, 2005).

La especie se caracteriza por presentar tres tipos de esporas asexuales: microconidios, macroconidios $y$ clamidosporas. Los microconidios son uni- o bicelulares y son los más abundantes y se producen por el hongo en cualquier circunstancia (medios sintéticos, haces vasculares de una planta infectada). Los macroconidios tienen de tres a cinco células separadas por septos y son alargadas, puntiagudas hacia los extremos y ligeramente curvados. Se encuentran comúnmente en la superficie de la planta muerta. Las clamidosporas, de una o dos células, son esféricas, de pared gruesa, producidas en las hifas de forma terminal o intercalar. Se desarrollan tanto en cultivos como en el hospedador en los estadios finales de la patogénesis (Agrios, 1997).

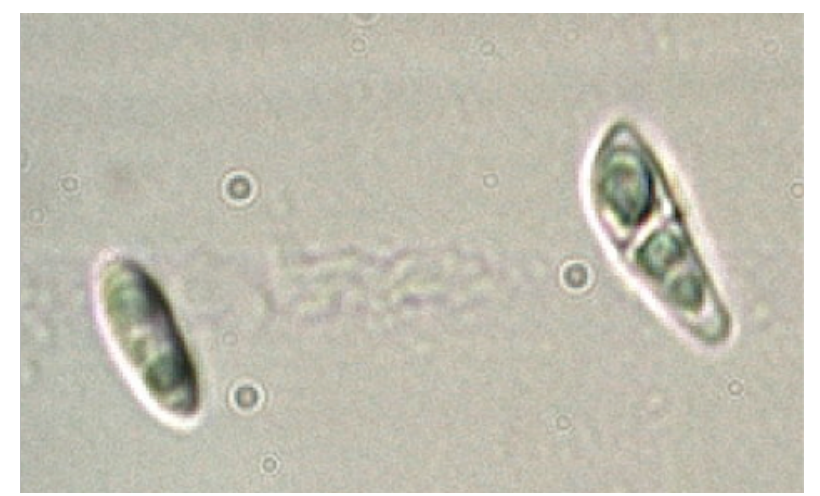

Figura 1. 5 - Microconidios de $F$. oxysporum tras 16 horas creciendo en medio de cultivo líquido.
1.2.5 - Formas especiales (formae speciales) de

\section{Fusarium oxysporum}

Aunque $F$. oxysporum tiene un amplio rango de hospedadores, las estirpes individuales son parásitos especializados de un número limitado de especies hospedadoras. El rango de hospedadores ha sido usado para subdividir esta especie en grupos de patógenos específicos, designados como formas especiales $\mathbf{0}$ formae speciales (f.sp.) (Snyder \& Hansen, 1940). En $F$. oxysporum se han descrito hasta el momento más de 70 formas especiales (Armstrong \& Armstrong, 1981).

Las formas especiales se caracterizan porque los aislados infectan una o varias especies vegetales, o incluso de una variedad de una especie vegetal. Por ejemplo, $F$. oxysporum f.sp. cucumerinum y $F$. oxysporum f.sp. lycopersici solo causan enfermedad en pepino y tomate, respectivamente. En cambio, F. oxysporum f.sp. radicis-cucumerinum y $F$. oxysporum f.sp. radicis-lycopersici, que además de infectar a pepino y tomate, causan la enfermedad en un rango mucho mayor de plantas (Rowe, 1980).

Cada forma especial de F. oxysporum consiste en uno $\mathrm{o}$ varios grupos de compatibilidad vegetativa (GCV O VCG). Cuando una forma especial agrupa varios GCV estos no son monofiléticos, lo que sugiere que la capacidad infectiva para un cierto hospedador ha surgido varias veces de forma independiente (O'Donnell et al., 1998; Baayen et al., 2000). 
Las formas especiales se distinguen mediante ensayos de patogenicidad, pero los resultados de éstos están influidos por las condiciones en que se realizan, la variabilidad genética de las plantas y la concentración de inóculo (Bosland, 1988). Recientemente, estas técnicas se complementan o reemplazan por técnicas moleculares. Estas técnicas se complican por la naturaleza polifilética de muchas (si no todas) las formas especiales, si bien para algunas se han descubierto marcadores específicos que permiten su identificación vía PCR (Lievens et al., 2008).

Aunque ocurren una serie de procesos comunes en las etapas de la infección por parte de un patógeno vascular, sin duda deben existir diferencias a nivel molecular que permitan diferenciar unos patógenos de otros en cuanto a la especificidad por el hospedador y su grado de virulencia. En este sentido, $F$. oxysporum es un buen modelo de

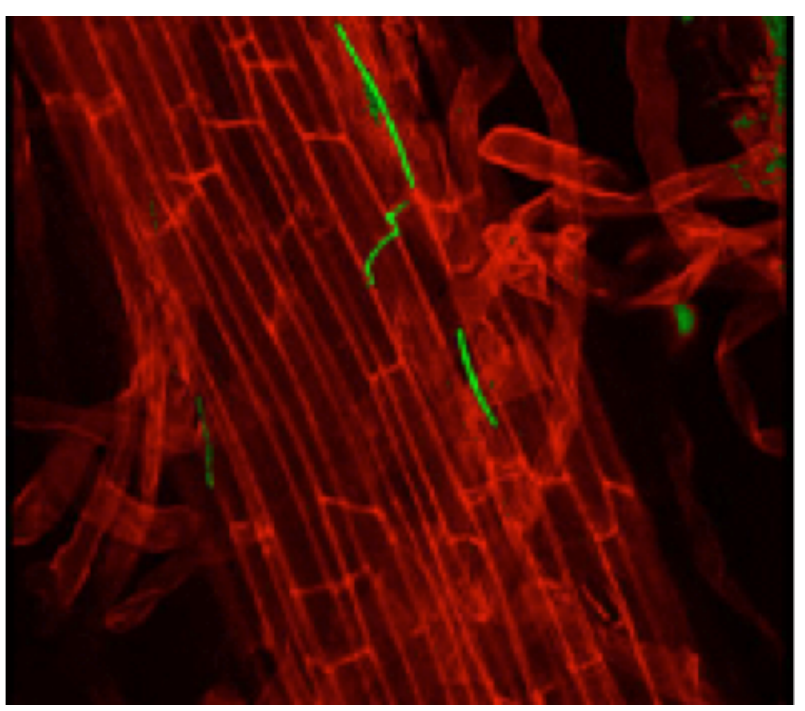

Figura 1. 6 - Desarrollo de F. oxysporum (verde -GFP-) en los haces vasculares de una planta de judía (rojo), visualizada mediante microscopía confocal (MartínRodrigues et al., 2007).

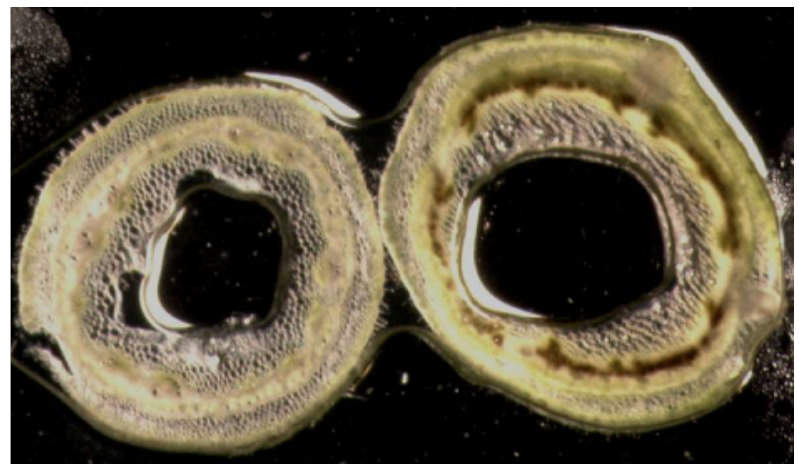

Figura 1. 7 - Corte transversal de un tallo de una planta de judía sana (izq.) e infectada (der.).

estudio al presentar las distintas formas especiales una elevada especificidad por las especies vegetales a las que infectan.

\subsection{6 - La fusariosis vascular}

La fusariosis vascular (Fusarium wilt) se caracteriza por los síntomas externos que presenta la planta: decaimiento, clorosis y marchitez hasta la muerte de la planta. En el interior de la planta el hongo se va desarrollando, colapsando los haces vasculares, que adquieren tonos marrones. La falta de agua y nutrientes provoca el decaimiento de la planta y la muerte. La marchitez aparece primero como un ligero aclarado del nervio en la parte exterior de las hojas más jóvenes, seguido de caída de las hojas más viejas.

En plantas jóvenes o de menor porte (como la judía), los vegetales se marchitan y mueren poco después de la aparición de la sintomatología externa. En plantas de mayor tamaño (como el judión o el tomate), aparecen con frecuencia el atrofiamiento $y$ amarilleo de las hojas inferiores, la formación de raíces adventicias, la defoliación marginal 
de las hojas restantes y en algunos casos, finalmente la muerte de la planta.

F. oxysporum se comporta como un habitante del suelo. Puede sobrevivir durante largos períodos de tiempo en ausencia del hospedador, generalmente en forma de clamidospora. Una vez que el suelo se ha contaminado con Fusarium spp. puede permanecer infectado indefinidamente (Agrios, 1997).

El proceso de infección comienza cuando el hongo entra en contacto con el sistema radicular del hospedador. Los aislados que presentan capacidad patogénica no presentan estructuras especiales para la infección, puesto que acceden a la planta a través de pequeñas heridas en las raíces hasta alcanzar el tallo y la corona de la planta donde se desarrollan.

Las etapas iniciales del proceso de la infección han podido observarse en $F$. oxysporum f. sp. lycopersici (Di Pietro et al., 2001), en F. oxysporum f.sp. radicis (Lagopodi et al., 2002) y en $F$. oxysporum $f$. sp. phaseoli, donde el seguimiento de la infección en raíz mediante microscopía confocal utilizando la proteína verde de fluorescencia (GFP, green fluorescent protein) ha permitido observar diferencias clave en la capacidad de penetrar y colonizar los haces vasculares entre estirpes con distinto grado de virulencia (Martín-Rodrigues et al., 2007).

Durante penetración y la colonización de la planta F. oxysporum secreta una gran cantidad de enzimas de degradación de la pared celular (CWDE "cell wall degrading enzimes"), como poligalacturonasas (PG), pectato liasas $(P L)$, xilanasas y proteasas que pueden contribuir a la infección (Beckman, 1987). Estas enzimas están codificadas por múltiples genes, con funciones redundantes, y la interrupción de los genes reguladores de las mismas no ha conllevado variaciones en la virulencia (Di Pietro et al., 2001; CaleroNieto et al., 2007).

\subsection{7 - F. oxysporum f.sp. phaseoli. la fusariosis vascular de la judía}

Fusarium oxysporum f. sp. phaseoli, es el agente causal de la fusariosis vascular o traqueomicosis en la judía (Phaseolus vulgaris L.) y el judión (Phaseolus coccineous L.). La capacidad de esta forma especial para infectar plantas de judíon ya había sido

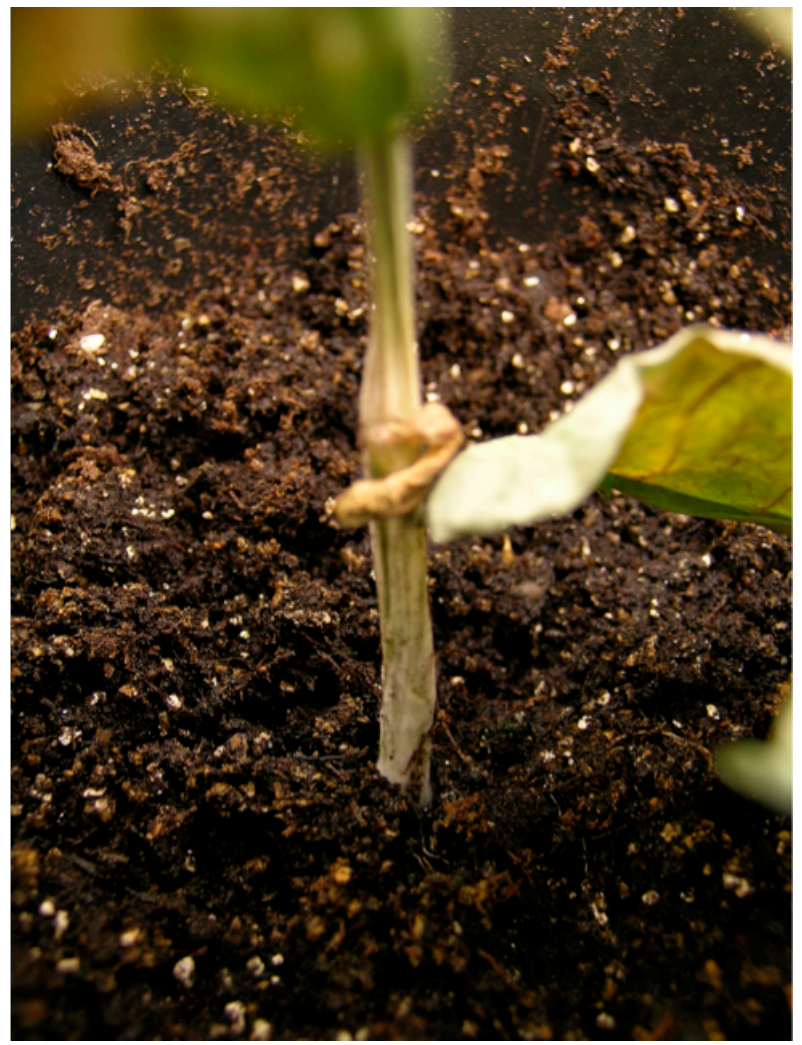

Figura 1.8 - Detalle de la progresión de la enfermedad en una planta de judía. El tallo muestra síntomas externos de necrosis y el hongo empieza a crecer también por la parte externa. 
constatada con anterioridad (Davies, 1942; Aloj et al., 1983), pero no estudiada en profundidad.

Se ha establecido una clasificación en "razas" en función de la capacidad patogénica de los aislados sobre una serie de variedades de judía preestablecidas. Hasta este trabajo, se han descrito 7 razas, que se corresponden a su vez con 7 GCV distintos (0161 a 0167): la raza 1 en Carolina del Sur (EE.UU.), y la raza 2 en Brasil, la raza 3 en Colombia, la raza 4 en Colorado (EE.UU.), la raza 5 en Grecia y las razas 6 y 7 en España y Grecia respectivamente (Alves-Santos et al., 2002a).

Los numerosos trabajos que han identificado a F. oxysporum f. sp. phaseoli como agente causal de la fusariosis vascular en judía reflejan la amplia distribución del patógeno en diferentes partes del mundo y la importancia de esta enfermedad. También son importantes los esfuerzos que se están dedicando a la búsqueda de variedades de judía resistentes.

A producción de judía alcanzó 18.724.766 toneladas en 2004 (FAOSTAT, 2004), siendo los mayores productores Brasil e India con unos 3.000.000 toneladas. Son un alimento de bajo coste, rico en proteínas e hidratos de carbono. El rendimiento es superior en Europa y Estados Unidos, superando los $1.500 \mathrm{Kg} / \mathrm{Ha}$. En España, la producción en 2004 alcanzó las 17.000 toneladas y la superficie cultivada ocupó $11.000 \mathrm{Ha}$ (FAOSTAT, 2004), representando el $15 \%$ de la producción de la Unión
Europea. Castilla y León produce una cuarta parte del total nacional (MAPA, 2004).

Nuestra área prioritaria de interés, la comarca de El Barco de Ávila está situada en el noroeste de la provincia de Ávila. La producción es de unas 125 toneladas sobre una superficie de aproximadamente $200 \mathrm{Ha}$. Permanece como cultivo tradicional y posee desde 1989 protección de "Denominación de origen". El problema sanitario más importante que padece el cultivo de la judía en El Barco de Ávila es la Fusariosis Vascular (DíazMínguez et al., 1996).

\subsection{8 - F. oxysporum f.sp. lycopersici. La fusariosis vascular del tomate}

La fusariosis vascular en tomate es una enfermedad presente en las regiones de producción masiva del cultivar en más de 32 paises. En F. oxysporum f.sp. lycopersici se han descrito tres razas fisiológicas que se distinguen por su respuesta a los genes de resistencia del tomate I-1, I-2 o I-3: la raza 1 fue la primera descrita en 1886 . La raza 2 ,

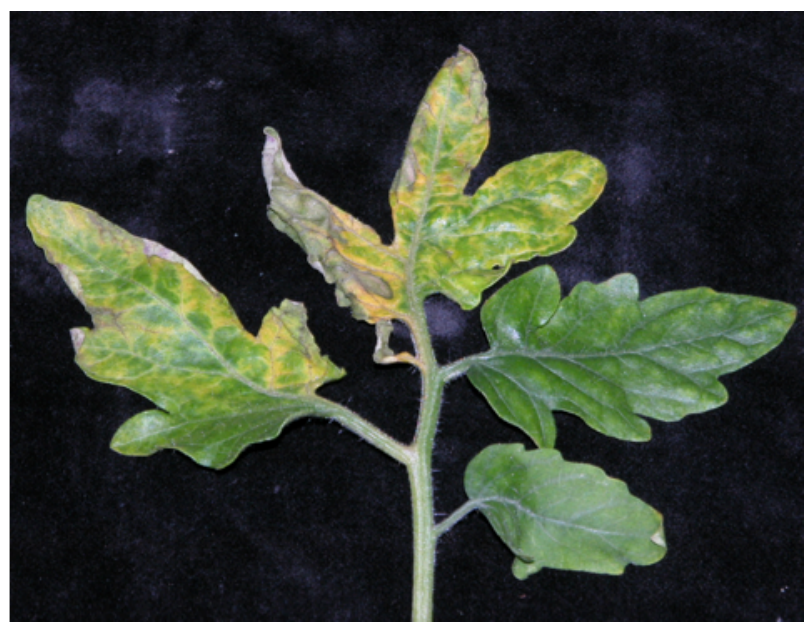

Figura 1. 9 - Sintomatología de la Fusariosis vascular en un hoja de tomate. 
descrita en Ohio en 1945, es menos abundante y es patógena sobre cultivares de tomate resistentes a la raza 1 (Booth, 1971). La raza 3, descrita en Australia en 1978, infecta todas las variedades de tomate conocidas (Beckman, 1987). La relación resultante se resumen así:

\begin{tabular}{|c|c|c|c|c|}
\hline & \multicolumn{3}{|c|}{ Gen R de tomate } \\
\hline & & $\mid-1$ & $1-2$ & $1-3$ \\
\hline \multirow{3}{*}{ 훈 } & Raza 1 & No virulenta & Virulenta o no & Virulenta o no \\
\hline & Raza 2 & Virulenta & No virulenta & Virulenta o no \\
\hline & Raza 3 & Virulenta & Virulenta & No virulenta \\
\hline
\end{tabular}

Se conocen cinco GCV, los GCV 0030, 0031, 0032 y 0035 incluyen aislados tanto de la raza 1 como de la raza 2. Los GCV 0033 y 0034 incluyen aislados de la raza 3 . Aislados de distinta raza pero el mismo GCV son más similares entre si que aislados de la misma raza pero distinto GCV, lo que sugiere procesos evolutivos similares pero ocurridos de forma independiente en distintas líneas (Cai et al., 2003).

\subsection{9 - Bases moleculares de la patogenicidad de $F$.} oxysporum

Los hongos patógenos necesitan responder adecuadamente al entorno de la planta mediante el ajuste de su morfología, fisiología y metabolismo; así como mediante la secreción de un conjunto de enzimas y metabolitos. Muchos genes identificados como factores de patogenicidad, aquellos cuya disrupción causa la pérdida de la capacidad infecciosa, participan también procesos generales como conidiación o apareamiento (Duyvesteijn et al., 2005).

La integridad de la pared celular tiene un papel crítico en el proceso de infección, probablemente resistiendo la acción de las enzimas de la planta o previniendo la activación de elicitores de defensa. El gen chs $\mathrm{V}$ es una quitinsintasa de tipo $\mathrm{V}$ implicada en la resistencia antimicrobiana y en la integridad de la pared celular. Cuando se interrumpe se producen alteraciones morfológicas y se pierde completamente la capacidad de infección. Así mismo, los disruptantes son hipersensibles a los antimicrobianos de la planta (Madrid et al., 2003). Análogamente, el gen ChsVb es una quitinsintasa y su disrupción ocasiona crecimiento aberrante, debilidad estructural e incapacidad para infectar y colonizar tomate (Martin-Urdiroz et al., 2008). También implicados en la integridad de la pared celular, el gen $R$ ho1 regula la morfogénesis y biosíntesis de la pared celular y GAS1 codifica una glucosiltransferasa. Los transformantes interrumpidos muestran alteraciones en la morfología de la pared celular (en el caso de GAS1 solo en medio sólido) y una importante pérdida de la virulencia en planta (Caracuel et al., 2005; Martinez-Rocha et al., 2008). En coherencia con la alteración de la membrana celular, los mutantes mostraran una mayor resistencia a enzimas de degradación probablemente por la alteración de los canales osmóticos (Caracuel et al., 2005).

Las proteinas $\mathrm{G}$ actúan como interruptores biológicos mediante la 
transducción de señales. Los genes que codifican para la subunidad alfa se denominan FGA1 y FGA2. Los disruptantes en el gen FGA1 mostraban alteración en la morfología de la colonia y disminución de la tasa de esporulación y la virulencia (Jain et al., 2002). En cambio, los disruptantes en FGA2 perdían completamente la capacidad infecciosa pero no mostraban otros cambios morfológicos (Jain et al., 2005). Así, FGA1 y FGA2 tienen funciones distintas, cada una necesaria para adaptarse a distintos entornos (Jain et al., 2005). Otro tipo de proteinas G son las subunidades beta. El gen FGB1 codifica para una subunidad beta y su interrupción ocasiona una pérdida de la patogenicidad pero no produce alteraciones en el crecimiento (Jain et al., 2003) a diferencia de FGB2 que codifica otra subunidad beta cuya disrupción causa disminución del crecimiento, esporulación y virulencia (Delgado-Jarana et al., 2005). También implicado en señalización, la interrupción de la proteína MAP quinasa con función en transducción sensorial FMK1, afecta la adhesión e infección de la raíz suprimiendo la capacidad patogénica de $F$. oxysporum (Di Pietro et al., 2001).

El gen FRP1 es una proteína con un dominio F-Box que forma parte del complejo proteico SCF. Las proteínas F-Box suelen estar implicadas en regulación del metabolismo básico y ciclo celular (Duyvesteijn et al., 2005). La mutagénesis del gen FRP1 causa una pérdida de la patogenicidad por perdida de la capacidad de apareamiento a la raíz pero no afecta ni a la producción de esporas ni a la viabilidad de las mismas (Duyvesteijn et al., 2005). De igual forma para un gen implicado en funciones básicas, la mutación del gen $A R G 1$, implicado en la biosíntesis de arginina, conlleva una pérdida de patogenicidad (Namiki et al., 2001). Los casos anteriores sustentan que la patogenicidad se adquiere por optimización de rutas metabólicas y de regulación comunes (Duyvesteijn et al., 2005).

Las enzimas de degradación de la pared celular (CWDE) juegan un papel relevante en el proceso de infección, sin embargo muestran un carácter redundante que dificulta su estudio (Apel-Birkhold \& Walton, 1996; Di Pietro et al., 2003; Wu et al., 2006) pues la mutagénesis individual no tiene efecto sobre la virulencia. Con el objeto de obviar este inconveniente, se ha tratado de inactivar una familia completa de enzimas mediante la alteración de su regulación. El factor de transcripción dedo de zinc $X I n R$ en $F$. oxysporum se induce en fuentes de carbono distintas a la glucosa y se reprime en presencia de la misma. XInR es el principal regulador de xilanasas. Sin embargo, de forma similar a la disrupción individual, la interrupción de $X \operatorname{InR}$ en $F$. oxysporum no causó alteración de la virulencia (Calero-Nieto et al., 2007).

Como se ha comentado las CWDE están reguladas por la fuente de carbono, reprimiéndose en presencia de glucosa y activándose con otras fuentes de carbono. Con el objeto de estudiar la relación entre fuente de carbono y CWDE se ha interrumpido el gen SNF1 en F. oxysporum 
(FoSNF1). El gen SNF1 ha sido ampliamente descrito en $S$. cerevisiae y es una activador de otros genes en estados de ausencia de glucosa. Los aislados de $F$. oxysporum con el gen FoSNF1 interrumpido muestran una velocidad de crecimiento reducida en diferentes fuentes de carbono y reducción de la virulencia como consecuencia de la reducción de la producción de CWDEs que comprometen el uso de fuentes de carbono alternativas (Ospina-Giraldo et al., 2003).

Se ha propuesto que este comportamiento tiene relevancia durante la infección pues el interior de la planta es un medio hostil y carente de nutrientes. Análogamente, la inactivación del regulador genérico de nitrógeno Fnr1 en $F$. oxysporum conllevó una perdida en la capacidad de usar distintas fuentes de nitrógeno, abolió la expresión de genes de nutrición y afectó a la virulencia alterando la inducción de genes necesarios para la adaptación a las condiciones pobres en nitrógeno tras la entrada en la planta (Divon et al., 2006; Divon \& Fluhr, 2007).

CTF1 es un factor de transcripción dedo de zinc $\mathrm{Zn}(\mathrm{II})_{2} \mathrm{Cys}_{6}$ caracterizado en $F$. oxysporum que regula la expresión de una cutinasa (cut1) y lipasa (lip1), implicadas en la hidrólisis de ácidos grasos durante el crecimiento, y ortólogo a CTF1 $\alpha$ en $F$. solani. Las cutinasas tienen un papel relevante en la penetración de la cutícula en hongos patógenos que penetran por la parte aérea. Los disruptantes CTF1 muestran una expresión residual de cut1 y lip1. CTF1 no muestra variaciones de expresión durante la infección en planta. Su disrupción no conlleva variaciones en la patogenicidad ni virulencia del hongo pero si en la tasa de crecimiento en varias fuentes de carbono. Es probable que lipasas y cutinasas no sean determinantes para la virulencia en patógenos de raíz (carente de cutina). Otra hipótesis es que existan reguladores distintos de CTF1 sobre lip1 y cut1 in planta (Rocha et al., 2008).

Otros factores de transcripción presentes en $F$. oxysporum son FOW2 y PacC. FOW2 no está implicado en crecimiento vegetativo, conidiación ni uso de fuentes distintas fuentes de carbono, pero es esencial para la colonización de los haces de la planta (Imazaki et al., 2007). El factor de transcripción PacC se regula por el $\mathrm{pH}$ del medio y muestra un incremento de la expresión en condiciones alcalinas y es indetectable en condiciones muy ácidas. En plantas, insectos y otros hongos, el $\mathrm{pH}$ del medio afecta la expresión de varios factores de virulencia. Al contrario que el resto de reguladores conocidos, la mutación de PacC en $F$. oxysporum causa un ligero incremento de la virulencia. Aparentemente, PacC es un regulador negativo de genes importantes para la infección (Caracuel et al., 2005). 


\section{3 - Los genes ftf1 y ftf2}

\subsection{1 - Diversidad de F. oxysporum f.sp. phaseoli}

\section{en España}

Hace unos doce años nuestro grupo comenzó a realizar inspecciones sistemáticas y periódicas de campos de judías de los alrededores de El Barco de Ávila (Ávila). A partir de estas muestras se aislaron más de 140 aislados de $F$. oxysporum. Los ensayos de infección llevados a cabo demostraron que el agente causal de la Fusariosis vascular observada en los campos (Benlloch \& Cañizo, 1926) es F. oxysporum f.sp. phaseoli (DíazMínguez et al., 1996).

Los aislados patógenos recolectados en la comarca de El Barco de Ávila pueden
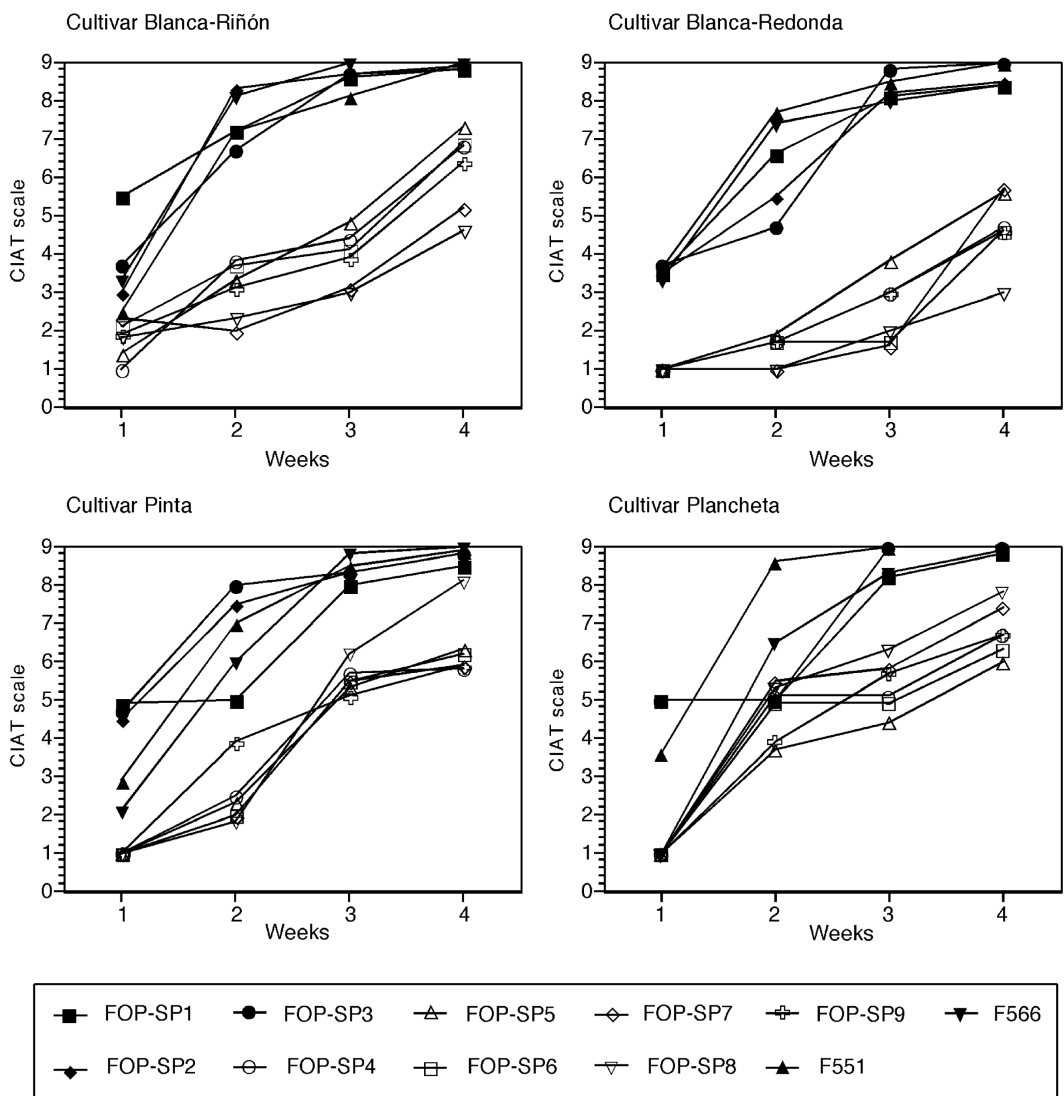

$$
\begin{aligned}
& \rightarrow \text { FOP-SP1 } \rightarrow \text { FOP-SP3 } \triangle \text { FOP-SP5 } \nrightarrow \text { FOP-SP7 } 九 \text { FOP-SP9 } \rightarrow \text { F566 } \\
& \downarrow \text { FOP-SP2 } \multimap \text { FOP-SP4 } \square \text { FOP-SP6 } \nabla \text { FOP-SP8 } 九 \text { F551 }
\end{aligned}
$$

Figura 1. 10 - Virulencia en cuatro variedades de judía ( $P$. vulgaris L..) tras la infección con once aislados de F. oxysporum f.sp. phaseoli virulencia estimado conforme al índice de producción de enfermedad de la escala CIAT (Pastor-Corrales \& Abawi, 1987) en variedades de judía españolas: altamente virulentos y débilmente virulentos. Sin embargo, esta diferenciación no fue aparente cuando se probaron variedades centroamericanas de judía (Alves-Santos et al., 2002a). Si bien es posible encontrar cultivares de judía resistentes para unas $u$ otras de las razas descritas en el continente americano; no se han encontrado hasta la fecha variedades resistentes a los aislados españoles de la raza 6 (Alves-Santos et al., 2002a).

Se realizó una caracterización

subdividirse en dos grupos según el grado de 
molecular de los aislados españoles obtenidos en judía ( $P$. vulgaris L.). Los aislados pertenecientes al mismo VCG mostraron el mismo haplotipo del IGS y variaciones del cariotipo menores, sustentando la representatividad entre VCG y líneas clonales. La comparación de los aislados españoles con aislados patógenos de otras procedencias geográficas permitió asignar tres nuevos VCG denominados 0166 , 0167 y 0168 . No se pudo establecer ninguna correlación entre los grupos de patogenicidad y compatibilidad vegetativa (Alves-Santos et al., 1999).

El estudio de la diversidad genética de los aislados de F. oxysporum f.sp. phaseoli, tanto patógenos como no patógenos, mediante RAPD (Ramdom amplified polymorphic DNA) permitió desarrollar un procedimiento de diagnóstico molecular mediante PCR. Este procedimiento se basa en la amplificación selectiva de un fragmento de ADN (con los cebadores B310 y A280) que es específico de los aislados patógenos altamente virulentos, con lo que constituye un SCAR (Sequence characterized amplified region) útil para uso en diagnóstico (AlvesSantos et al., 2002b). El análisis de la secuencia nucleotídica completa del SCAR B310-A280 reveló la existencia de un marco de lectura abierto (ORF, open reading frame) en parte de su secuencia, que permitió aislar un nuevo gen.

\subsection{2 - Aislamiento de ftf1}

El estudio de la secuencia de este gen, que se denominó ftf1 (Fusarium transcription factor 1), reveló la existencia de un dominio de unión al ADN (DBD) dedo de zinc binuclear o $\mathrm{Zn}(\mathrm{II})_{2} \mathrm{Cys}_{6}$ y un dominio o región de mediana homología (MHR) característico de factores de transcripción, ambos específicos de hongos. También se comprobó que la región B310-A280 se corresponde con la región del promotor inmediatamente anterior al origen de traducción putativo (Ramos et al., 2007).

Los dominios dedo de zinc están formados por uno o más átomos de zinc rodeados de aminoácidos cisteína o histidina. La mayoría se une al ADN (o ARN) tomando importantes papeles en la transcripción y traducción (Laity et al., 2001). Un subtipo de estos, los dominios dedo de zinc binuclear o $\mathrm{Zn}(\mathrm{II})_{2} \mathrm{Cys}_{6}$ están formados por dos átomos de zinc $y$ seis histidinas. Se distinguen tres regiones: el dedo de zinc, el enlace (linker) y las regiones de dimerización (MacPherson et al., 2006). El dedo de zinc se organiza en dos subestructuras, formada cada una por tres cisteínas rodeadas de aminoácidos básicos y separadas por un bucle. Habitualmente se sitúa en el extremo $\mathrm{N}$-terminal. La región de enlace se dispone en sentido C-terminal con respecto a la región rica en cisteínas. Su secuencia y distribución espacial varía entre diferentes proteínas, pero está asociada a la función de la proteína, pues si se intercambia esta región con la de otra proteína análoga o su secuencia muta, la funcionalidad se pierde 
(Johnston \& Dover, 1987; Mamane et al., 1998). Las regiones de dimerización, se sitúan a continuación en sentido C-terminal. Formadas por septetos repetidos de aminoácidos y responsables de la dimerización y las interacciones proteínaproteína.

El segundo dominio, la Región de

\section{Mediana Homología (MHR), parece} funcionar como un regulador de la expresión del factor de transcripción pues su deleción conlleva su activación constitutiva (Friden et al., 1989; Schjerling \& Holmberg, 1996).
Normalmente en el extremo C-terminal de la proteína, aparece una región no conservada, rica en residuos aspartato y glutamato que le dan un carácter característico ácido. Se denomina dominio de activación y juega un papel diferente en cada proteína, en algunos casos se han localizado señales transmembrana, y su modificación ocasiona una modificación de la función o la perdida de la misma (MacPherson et al., 2006).

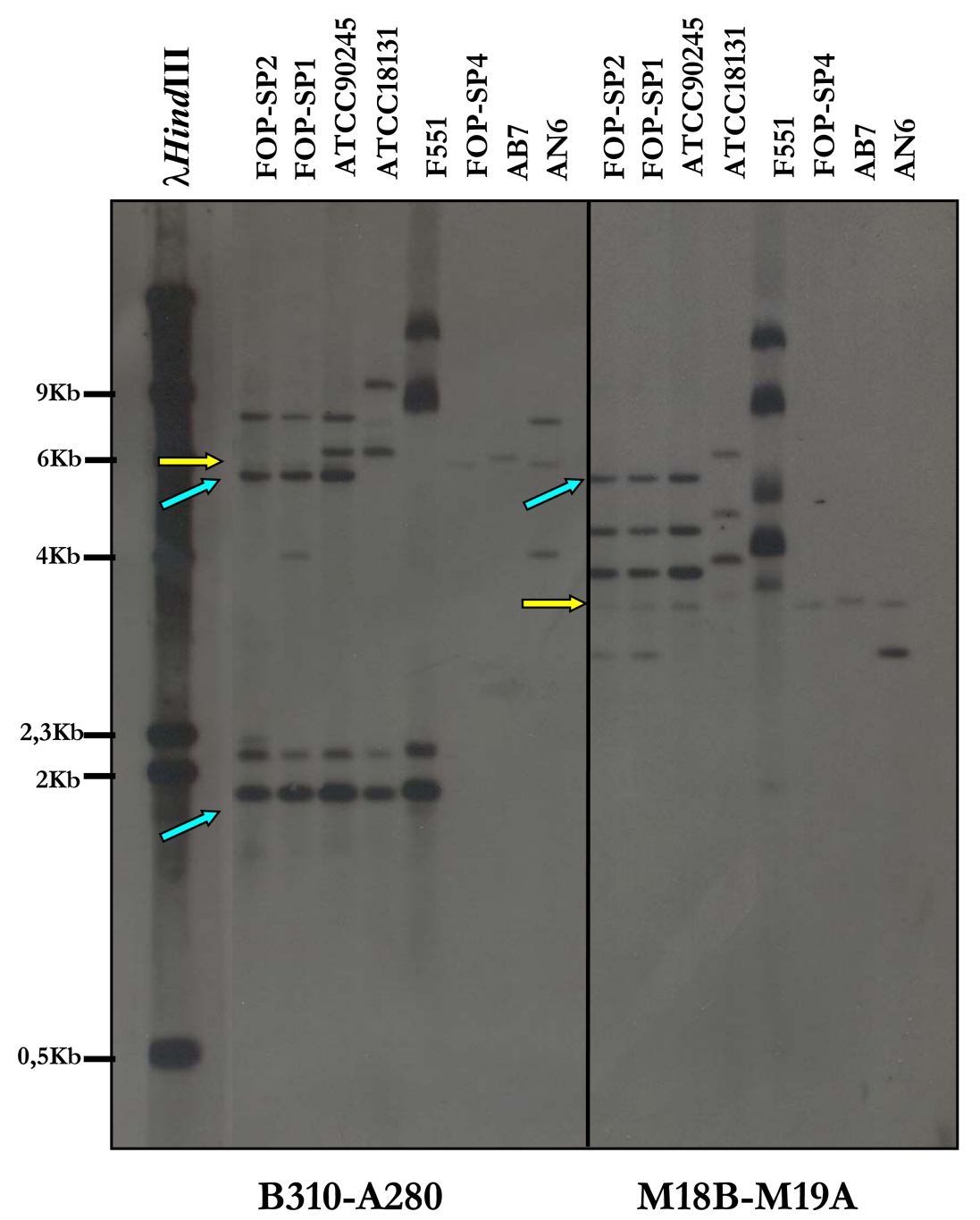

Figura 1. 11 - Hibridizaciones tipo Southern de ADN genómico de estirpes de $F$. oxysporum con las sondas B310-A280 y M18B-M19A de ftf1a (Ramos, 2005). Las flechas amarillas indican la señal presente en todos los aislados (ftf2) y las flechas azules las copias: ftf1a (aprox. 5,3 kbp) y ftf1b (1,8 kbp). 


\subsection{3 - Caracterización de ftf1}

Mediante PCR se amplificó la secuencia SCAR B310-A280 en aislados de $F$. oxysporum pertenecientes a varias formas especiales, obteniéndose una banda en las formas especiales betae, pisi, lycopersici, cubense. La posterior secuenciación y alineamiento de estos fragmentos amplificados y de la secuencia de la forma especial phaseoli, evidenció una homología superior al 95\%. También se amplificó un fragmento del comienzo de la región codificante (con los cebadores B5 y M17A). Se obtuvieron bandas en todas las formas especiales estudiadas, lo que revela una mayor similitud en esta región que en la del promotor entre distintas formas especiales (Nuñez Corcuera, 2004; Ramos et al., 2007).

No se pudo detectar expresión de ftf1 en cultivo líquido (in vitro) mediante northern ni RT-PCR (Reverse transcription PCR). Sin embargo, el estudio mediante PCR cuantitativa en tiempo real de la expresión de ftf1 en plantas de judía, reveló una clara inducción durante las primeras 48 horas, con un máximo a las 24 horas en los aislados altamente virulentos. Esto sugiere un papel importante de ftf1 en la estabilización de la infección 0 en las primeras fases de la enfermedad (Ramos et al., 2007).

Cuando se obtuvieron mutantes interrumpidos en ftf1 no se observaron variaciones en la virulencia sobre planta de judía cuando se comparó con la de aislados silvestres. Hibridaciones tipo Southern con sondas del gen marcador (higromicina) y de las regiones codificante (M18B-M19A) y promotora (B310-A280), demostraron la existencia de al menos cuatro copias de ftf1 en los aislados silvestres altamente virulentos de F. oxysporum f.sp. phaseoli, y la correcta inserción del gen marcador en una de las copias de ftf1 en los disruptantes, pasando a denominarse la copia originalmente secuenciada como ftf1a. (Ramos 2007).

En F. oxysporum f.sp. phaseoli, las cuatro copias están integradas en el menor de los cromosomas (1,8 Mbp). Aproximadamente 1,3 kbp aguas debajo del codón de parada de ftf1a se ha encontrado una secuencia homologa al transposón Marsu. El transposón Marsu solo aparece en el menor cromosoma, y al igual que ftf1, esta ausente en los aislados débilmente virulentos y no patógenos de $F$. oxysporum f.sp. phaseoli (Ramos et al., 2007).

\subsection{4 - Descubrimiento de ftf2}

En las hibridaciones tipo Southern con las sondas M18B-M19A y B310-A280, se observó una banda más tenue que las cuatro copias polimórficas de ftf1, que estaba presente en todos los carriles, incluyendo estirpes débilmente virulentas y no patógenas de F. oxysporum f.sp. phaseoli. El posterior aislamiento permitió obtener una nueva secuencia, que se corresponde con un nuevo gen, que muestra una alta homología (83 \%) en la región codificante con $f t f 1$, por lo que se denominó ftf2 (Fusarium transcription factor 2). Se encontraron homólogos a ftf2 en los genomas secuenciados de los hongos $F$. 
graminearum, $M$. grisea, $N$. crassa, $A$. nidulans, $U$. maydis, $C$. cinereus y $C$. neoformans (Ramos, 2005).

La región promotora de ftf2 está completamente conservada entre aislados con distinta virulencia y no patógenos de $F$. oxysporum f.sp. phaseoli. Sin embargo, cuando se compara con el promotor de ftf1 se evidencian mayores diferencias entre ellos. Solo una de las cuatro cajas TATA de ftf1 está conservada en ftf2 y la homología entre los promotores de ftf1 y ftf2 es de aproximadamente un 65 \% (Ramos, 2005), lo que sugiere una regulación diferente. 



\section{Objetivos/Objectives}



Based on the previous discoveries and the line of work of our research group, this thesis expects to continue the study of the transcription factors ftf1 and ftf2 in the pathogenic fungus Fusarium oxysporum.

Therefore, we set out to achieve the following objectives:

1. - Characterization of virulence in new isolates of $F$. oxysporum f.sp. phaseoli.

2. - Analysis of $f t f 1$ and $f t f 2$ expression in different strains.

3. - Analysis of the genomic architecture of the copies of both genes in the genus Fusarium and other plant pathogens.

4. - Characterization of transformants with ftf1 and ftf2 altered expression.

5. - Identification of genes regulated by $f t f 1$ and $f t f 2$ as a way to know about the function of both genes. 

Tomando como base los descubrimientos anteriores y la línea de trabajo de nuestro grupo de investigación, esta tesis pretende continuar el estudio de los factores de transcripción ftf1 y ftf2 en el hongo patógeno Fusarium oxysporum.

Por tanto, nos propusimos alcanzar los siguientes objetivos:

1. - Caracterización de la virulencia en nuevos aislados de F. oxysporum f.sp. phaseoli.

2. - Análisis de la expresión de ftf1 y ftf2 en diferentes estirpes

3. - Análisis de la arquitectura genómica de las copias de ambos genes en el género Fusarium y en otros patógenos vegetales.

4. - Caracterización de transformantes con la expresión de ftf1 y ftf2 alterada.

5. - Identificación de los genes regulados por ftf1 y ftf2 como una vía para clarificar la función de ambos genes. 



\section{Materiales y métodos}





\section{1 - Organismos}

\subsection{1 - Bacterias}

\subsubsection{1 - Cepa de Escherichia coli}

DH5 $\alpha[F-, \Phi 80$ dlacZAM15, $\Delta$ (lacZYA$\operatorname{argF)U169,}$ recA1, endA1, hsdR17 $\left(r_{K^{-}}, m_{K}\right)$, phoA, supE44, thi-1, gryA96, relA1, lambda-], se utilizó en los experimentos de transformación bacteriana y para la propagación de plásmidos.

\subsubsection{Cepa de Agrobacterium tumefaciens}

AGL-1 [AGLO, recA::bla, pTiBo542 ( $\Delta) T$ $M o p+C b R]$. Utilizada en la transformación de Fusarium, su principal característica es portar un vector binario necesario para la transformación de hongos.

\subsection{2 - Hongos}

\subsubsection{1 - Fusarium oxysporum f.sp. phaseoli}

En la tabla 3. 2 (Pág. 61) se clasifican las estirpes utilizadas atendiendo a su origen, virulencia (según la escala CIAT), procedencia y grupo de compatibilidad vegetativa (Puhalla, 1985; Correll et al., 1987).

Todos los cultivos, tanto sólidos como líquidos de los distintos aislados de Fusarium oxysporum f.sp. phaseoli se recogieron a partir de micelios obtenidos a partir de un cultivo monospórico en PDA, recogidos en glicerol estéril al $25 \%$ y congelados a $-80^{\circ} \mathrm{C}$.
Dichos cultivos monospóricos, (de los que existe una copia A y otra B, a su vez duplicadas), proceden de un "cultivo madre", que es el hongo recogido de una planta enferma en una localización geográfica concreta y aislado de otros microorganismos mediante su incubación en diferentes medios selectivos, y comprobada su pertenencia a Fusarium oxysporum f.sp. phaseoli (AlvesSantos et al., 1999).

\subsubsection{2 - Otras formas especiales de Fusarium oxysporum}

Como se observa en la tabla 3. 3 (Pág. 62) se usaron otras cepas de múltiples formas especiales de Fusarium oxysporum provenientes de colecciones de una gran variedad de sitios. Todas las cepas que usamos son patógenas de su respectivo hospedador.

\subsection{3 - Plantas}

\subsubsection{1 - Phaseolus vulgaris L. (Judía)}

Para los ensayos de infección en judía se utilizaron semillas de la variedad Blanca Riñón cultivada en la región de El Barco de Ávila (Ávila). 


\subsubsection{2 - Phaseolus coccineous L. (Judión)}

Para los ensayos de infección en judión se utilizaron semillas de la variedad local de la región de El Barco de Ávila (Ávila).

\subsubsection{3 - Solanum lycopersicum L. (Tomate)}

Para los ensayos de infección en tomate se utilizaron semillas comerciales de la variedad "Roma VF" de la marca Vilmorin (Francia).

\section{2 - Medios y condiciones de cultivo}

\subsection{1 - Escherichia coli}

LB: (Luria-Bertani), extracto de levadura (Difco), 0,5\%; bactotriptona (Difco), $1 \%$; y $\mathrm{NaCl}, 1 \%$. Se añadió agar al 1,5\% $(\mathrm{w} / \mathrm{v})$ para el medio sólido. Fue el medio habitual utilizado para el cultivo de esta bacteria.

2xTY: extracto de levadura (Difco) $1 \%$, bactotriptona (Difco) 1,6 \% y NaCl 0,5\%.

Las condiciones de cultivo fueron las descritas por Sambrook y colaboradores (Sambrook et al., 1989). La temperatura de incubación fue $37^{\circ} \mathrm{C}$ tanto para los medios sólidos como líquidos.

El crecimiento en medio líquido se determinó, cuando fue necesario, midiendo la turbidez de los cultivos por su densidad óptica a $600 \mathrm{~nm}$. Todas las estirpes se conservaron en viales con glicerol al 50\% (v/v) a $-80^{\circ} \mathrm{C}$. Cuando fue necesario y según los plásmidos utilizados, estos medios se suplementaron con ampicilina $(100 \mu \mathrm{g} / \mathrm{ml}) \mathrm{y} / \mathrm{o}$ kanamicina $(50 \mu \mathrm{g} / \mathrm{ml})$.
3.2.2 - Agrobacterium tumefaciens

La temperatura óptima de crecimiento es de $28^{\circ} \mathrm{C}$. Para su crecimiento se utilizó el medio LB más los antibióticos correspondientes en cada caso. Otros medios utilizados se detallan en el apartado correspondiente a la transformación.

3.2.3 - Fusarium oxysporum

\subsubsection{1 - Medios líquidos}

PDB (Potato Dextrose Broth, Difco):

$24 \mathrm{~g} / \mathrm{l}$ de agua destilada. Cuando fue necesario prevenir crecimiento bacteriano se añadió al medio el antibiótico cloranfenicol (20 $\mu \mathrm{g} / \mathrm{ml})$. Para esporulación abundante: 22$28{ }^{\circ} \mathrm{C}$ y 180 r.p.m. Para crecimiento de micelio: $22-28{ }^{\circ} \mathrm{C}$ y 150 r.p.m.

\section{Medio Basal o medio mínimo (MM):} (Correll et al., 1987) $\mathrm{KH}_{2} \mathrm{PO}_{4} \cdot 7 \mathrm{H}_{2} \mathrm{O}(0,5 \mathrm{~g})$, $\mathrm{NaNO}_{3}(2 \mathrm{~g}), \mathrm{KCl}(0,5 \mathrm{~g}), \mathrm{FeSO}_{4} \cdot 7 \mathrm{H}_{2} \mathrm{O}(10 \mathrm{mg})$, agar (20 g), solución de elementos traza $(0,2$ ml) en 1 I de agua destilada: Ácido cítrico (5 g), $\mathrm{ZnSO}_{4} \cdot 7 \mathrm{H}_{2} \mathrm{O}(5 \mathrm{~g}), \mathrm{Fe}\left(\mathrm{NH}_{4}\right)_{2}\left(\mathrm{SO}_{4}\right)_{2} \cdot 6 \mathrm{H}_{2} \mathrm{O}(1$ g), $\mathrm{CuSO}_{4} \cdot 5 \mathrm{H}_{2} \mathrm{O}(0,25 \mathrm{~g}), \mathrm{MnSO}_{4} \cdot \mathrm{H}_{2} \mathrm{O}(50 \mathrm{mg})$, 
$\mathrm{H}_{3} \mathrm{BO}_{4}(50 \mathrm{mg})$ y $\mathrm{NaMoO}_{4} \cdot 2 \mathrm{H}_{2} \mathrm{O}(50 \mathrm{mg})$ en $100 \mathrm{ml}$ de agua destilada.

El nitrato sódico se puede reemplazar por otras fuentes de nitrógeno:

MMN: Medio basal con nitrito sódico $\mathrm{NaNO}_{2}(0,5 \mathrm{~g} /$ litro).

MMH: Medio basal con hipoxantina (0,2 g / litro).

MMC: Medio basal con clorato potásico $\mathrm{Cl}_{2} \mathrm{PO}_{4}(15 \mathrm{~g} /$ litro).

Medio mínimo (MM)+Glucosa: Medio Basal más $30 \mathrm{~g}$ de glucosa.

YPSS: Yeast Extract (Difco), $(4 \mathrm{~g})$; sacarosa (15 g), $\mathrm{K}_{2} \mathrm{HPO}_{4}(1 \mathrm{~g})$ y $\mathrm{MgSO}_{4}(0,5 \mathrm{~g})$ en 1 litro de agua destilada.

Medio Sintético (SM): (Di Pietro et al., 2001) $\mathrm{MgSO}_{4} \cdot 7 \mathrm{H}_{2} \mathrm{O}(0,2 \mathrm{~g}), \mathrm{KH}_{2} \mathrm{PO}_{4}(0,4 \mathrm{~g})$, $\mathrm{KCl}(0,2 \mathrm{~g}), \mathrm{NaNO}_{3}(1 \mathrm{~g}), \mathrm{FeSO}_{4}(0,01 \mathrm{~g})$, $\mathrm{MnSO}_{4}(0,01 \mathrm{~g}), 1 \%(\mathrm{w} / \mathrm{v})$ de glucosa, en 1 litro de agua destilada.

La glucosa se reemplaza por otras fuentes de carbono: $1 \%(\mathrm{w} / \mathrm{v})$ de trehalosa (SM-trehalosa), maltosa (SM-maltosa), xilosa (SM-xilosa), etc.

SM-Glu: Medio sintético sin glucosa (ni otra fuente de carbono).

SM-N: Medio sintético $\sin \mathrm{NaNO}_{3}$ (ni otra fuente de nitrógeno).

SM4: Medio sintético a $\mathrm{pH} 4$ tras añadir $\mathrm{NaH}_{2} \mathrm{PO}_{4}(100 \mathrm{mM})$ y $\mathrm{NaCl}(100 \mathrm{mM})$.

SM6: Medio sintético a $\mathrm{pH} 6$ tras añadir $\mathrm{NaH}_{2} \mathrm{PO} 4(50 \mathrm{mM}), \mathrm{NaHPO}_{4} \cdot 12 \mathrm{H}_{2} \mathrm{O}(50$ $\mathrm{mM})$ y $\mathrm{NaCl}(50 \mathrm{mM})$.

SM8: Medio sintético a $\mathrm{pH} 8$ tras añadir $\mathrm{NaHPO}_{4} \cdot 12 \mathrm{H}_{2} \mathrm{O}(100 \mathrm{mM})$.

\subsubsection{2 - Medios sólidos}

Para crecimiento en placa: $22-28{ }^{\circ} \mathrm{C} /$ PDA (Potato Dextrose Agar, Difco), $39 \mathrm{~g} / \mathrm{l}$ de agua destilada.

Agar-agua: $30 \mathrm{~g} / \mathrm{l}$ de agua destilada. Para la obtención de micelio procedente de un microconidio o una única espora uninucleada, se tomaron esporas de cultivo en placa resuspendidas en $10 \mu \mathrm{l}$ de agua estéril. Se hicieron diluciones seriadas y se repartieron en placas agar-agua. Se incubaron a $22{ }^{\circ} \mathrm{C}$ durante $10-12$ horas. Transcurrido este tiempo, las esporas germinadas se observaron mediante una lupa binocular y con un punzón estéril se tomó una única espora en un pequeño trozo de agar, que se colocó en una placa de PDA. Estas placas se incubaron a $22^{\circ} \mathrm{C}$ hasta que el micelio ocupó toda la placa. Para su conservación a largo plazo se obtuvieron suspensiones de micelio y conidios de la placa madre y dos aislados monospóricos (copia A y B, a su vez duplicadas) de cada aislado original (cultivo madre). Se resuspendieron en glicerol $25 \%$ y se guardaron congeladas a $-80^{\circ} \mathrm{C}$.

Medio sintético (SM) y todas sus variaciones comentadas, a los que se añaden $15 \mathrm{~g}$ de agar por litro.

\subsection{4 - Plantas}

\subsubsection{1 - Ensayos en cámara}

Las semillas de judía o judión (no se hizo ningún ensayo con tomate en cámara) se 
sembraron en vermiculita (Projar, SA), que se esterilizó mediante dos ciclos de autoclave de 60 minutos de duración. Una vez por semana se añadió en el agua de riego fertilizante líquido comercial (Projar, SA).

Las plantas se mantuvieron en cámaras de crecimiento controlado a temperatura: $22-25^{\circ} \mathrm{C}$, humedad relativa 60 $70 \%$ y fotoperíodo: 12 horas de luz-12 horas oscuridad.

\subsubsection{1 - Ensayos en invernadero}

Las semillas de judía y judión se sembraron en macetas de 0,52 litros (lado 9 $\mathrm{cm}$ y altura $9,5 \mathrm{~cm}$ ) con una mezcla de tierra vermiculita en relación 3:1. Las semillas de tomate se sembraron en macetas de 2,5 litros (diámetro $16 \mathrm{~cm}$ y altura $15 \mathrm{~cm}$ ) o bandeja semillero con la misma mezcla de tierra y vermiculita.

El invernadero se mantuvo a temperatura controlada con una mínima de $15^{\circ} \mathrm{C}$ y una máxima de $35^{\circ} \mathrm{C}$ dependiendo de la época del año, con una media de 20-25 ${ }^{\circ} \mathrm{C}$. En invierno se reforzó el fotoperiodo con luz artificial hasta completar las 12 horas. La humedad relativa se mantuvo entre 50-60\%. Se enriqueció con abono la mezcla de sustrato. Se regó con agua corriente regularmente.

\section{3 - Ensayos de infección}

Los ensayos para analizar la patogenicidad y virulencia de los aislados silvestres y sus transformantes fueron realizados según el método descrito por Pastor-Corrales y Abawi y cuantificados mediante la escala CIAT (Pastor-Corrales \& Abawi, 1987).

Se inocularon $150 \mathrm{ml}$ de medio PDB con el aislado correspondiente y se cultivaron a 180 r.p.m. y $25{ }^{\circ} \mathrm{C}$ durante 5-7 días. El día que se realizó el ensayo se filtraron las esporas del medio de cultivo a través de una gasa doble estéril. Se lavaron 3 veces con agua destilada estéril, centrifugándolas a 3.500 r.p.m. durante 5 minutos y se cuantificaron al microscopio con una cámara de citometría Thoma. Las esporas se mantuvieron a $4{ }^{\circ} \mathrm{C}$ hasta el momento de la infección.

Las semillas de judía y judión se desinfectaron (un lavado de 5 minutos con hipoclorito sódico y varias veces en agua destilada estéril) para su siembra. Se mantuvieron en las cámaras germinadoras o el invernadero según las condiciones del apartado anterior.

Cuando se observó el desarrollo de las hojas cotidelónicas tras 8-10 días de cultivo, las plántulas fueron retiradas de las macetas o semilleros. Se lavaron las raíes con abundante agua y se cortaron los ápices radiculares con unas tijeras simulando una lesión radicular. Las plantas fueron entonces introducidas en vasos de precipitado con 50 
$\mathrm{ml}$ de una suspensión de esporas en agua (10e6 esporas $/ \mathrm{ml}$ ) durante 5 minutos tras lo cual fueron replantadas.

La medición del ensayo se hizo según la escala CIAT (Pastor-Corrales \& Abawi, 1987), en la que se calcula el porcentaje de hojas de la planta que muestran síntomas de clorosis, amarilleamiento, marchitez, necrosis y/o caída prematura y se asigna un número del 1 al 9 conforme al porcentaje de hojas con lesiones respecto al total de hojas de la planta:

\begin{tabular}{|c|c|}
\hline Escala CIAT & \% hojas sintomática \\
\hline 1 & $<5$ \\
\hline 2 & $<10$ \\
\hline 3 & $<15$ \\
\hline 4 & $<20$ \\
\hline 5 & $<35$ \\
\hline 6 & $<40$ \\
\hline 7 & $<50$ \\
\hline 8 & $<75$ \\
\hline 9 & $>=75$ \\
\hline
\end{tabular}

La incidencia de la enfermedad se estima semanalmente desde la infección y durante 4 semanas, y según este índice se puede considerar una planta como resistente
(R), cuando el índice se encuentra entre 1 y 3 o susceptible (S), si el índice es superior a 3. Según la susceptibilidad de la planta establecemos también una clasificación de los aislados del hongo según su capacidad patogénica y de virulencia en la variedad local “Blanca Riñón” (Alves-Santos et al., 1999).

El progreso de la enfermedad se evalúa a distintos tiempos a partir del momento de la infección, en función de la virulencia del patógeno. Para observar las diferencias entre las estirpes silvestres, transformantes, mutantes y los controles negativos, se calcula la media y la desviación estandar de las plantas infectadas con cada estirpe, asi como las no infectadas como control.

A partir de estos datos definimos el Índice de Progreso de la Enfermedad (DPR, Disease Progression Rate), que obtenemos mediante la fórmula $\mathrm{DPR}=\Sigma \mathrm{i} \mathrm{Xi} / \mathrm{n}$, para $\mathrm{i}=1,2, \ldots, \mathrm{n}$; donde $\mathrm{Xi}$ representa la media de la severidad de la infección según la escala CIAT de 1 (planta sana) a 9 (planta muerta) y $\mathrm{n}$ representa el número de días transcurridos tras la inoculación. En este estudio se calculó a partir de los datos de la segunda, tercera y cuarta semanas.

\section{4 - Estudio de Grupos de Compatibilidad Vegetativa (VCG)}

\subsection{1 - Obtención de mutantes nit}

La obtención de mutantes nit se realizó mediante la transferencia de un bloque de micelio a placas Petri con medio PDC o
MMC (Correll et al., 1987). Las placas se incubaron durante 1-3 semanas y se observaron periódicamente para comprobar la aparición de sectores de crecimiento rápido desde la colonia inicial. Estos sectores 
de crecimiento rápido corresponden a los mutantes resistentes a clorato potásico, que fueron transferidos a placas de PDA.

Para analizar el fenotipo de los mutantes se realizó la transferencia de un bloque de micelio a medios con diferentes fuentes de nitrógeno: MM, MMN y MMH. Los mutantes que no son capaces de utilizar alguna de estas fuentes de nitrógeno crecen como un micelio muy fino. En cambio, cuando son capaces desarrollan un micelio aéreo denso como el tipo silvestre.

\subsection{2 - Ensayo de complementación}

Para establecer los grupos de compatibilidad vegetativa (VCGs) se realizaron emparejamientos entre distintos mutantes nit. Para realizar esta prueba, se colocaron cuatro trozos de micelio separados unos $4 \mathrm{~cm}$ en una placa de medio MM y se incubaron hasta que los micelios desarrollados entraron en contacto. Este proceso se repitió tantas veces como fue necesario hasta completar todos los emparejamientos posibles entre los mutantes de un mismo aislado para comprobar que no fuese autoincomplatible, es decir, que no formase heterocariontes por tener afectada su capacidad de anastomosis.

\section{5 - Obtención y cuantificación de ácidos nucleicos}

\subsection{1 - ADN genómico del hongo}

\subsubsection{1 - Gradiente de Cloruro de Cesio}

Este método se utilizó para obtener grandes cantidades de ADN de buena calidad. En primer lugar se preparó un preinóculo en $50 \mathrm{ml}$ de PDB. Se mantuvo durante 2 días a $25^{\circ} \mathrm{C}$ y 180 r.p.m. para favorecer la esporulación. Pasado este tiempo se inocularon $500 \mu \mathrm{l}$ en 1 litro de PDB (y en algunos casos, más cloranfenicol 20 $\mu \mathrm{g} / \mathrm{ml}$ ), durante 4 días a $25^{\circ} \mathrm{C}$ y 120 r.p.m. para favorecer el crecimiento de micelio. El micelio se separó de las esporas y el medio mediante filtración a través de gasas estériles de doble capa. Se eliminó el exceso de líquido con papel de filtro, se pesó y se congeló a $-80{ }^{\circ} \mathrm{C}$ hasta su utilización. Se trituraron $5 \mathrm{mg}$ de micelio en un mortero con nitrógeno líquido hasta ser reducido a un polvo fino. Éste se transfirió a tubos Corex de $30 \mathrm{ml}$ a los que se añadió inmediatamente la solución de lisis $(1 \mathrm{ml}$ por cada gramo de micelio aproximadamente): Tris- $\mathrm{HCl} 50 \mathrm{mM}$ pH 8.0; EDTA 20 mM; n-laurilsarcosina $1 \%$ (w/v). Se mezcló y se incubó a $65^{\circ} \mathrm{C}$ durante 15 minutos con 2 agitaciones vortex en la incubación.

Se centrifugó a 6.000 r.p.m. durante 15 minutos y se recogió la fase acuosa por decantación. Para eliminar el ARN de la 
muestra, se añadió ARNasa A $50 \mu \mathrm{g} / \mathrm{ml}$ y se incubó a $37^{\circ} \mathrm{C}, 30$ minutos. Después se añadió Proteinasa $\mathrm{K} 50 \mu \mathrm{g} / \mathrm{ml}$ y se incubó durante $1 \mathrm{~h}$ más. Se centrifugó de nuevo a 6.000 r.p.m. durante $15 \mathrm{~min}$. Se recogió la fase acuosa con una pipeta a cuya punta se cortó el extremo.

Para preparar el gradiente de $\mathrm{CsCl}$ se utilizaron tubos de polipropileno de $10 \mathrm{ml}$ forrados con papel de aluminio a los que se añadió $\mathrm{CsCl}(7,8 \mathrm{~g})$, bisbenzimida $(0,5 \mathrm{ml})$, la solución acuosa que contenía el ADN y tampón TE (Tris-HCl $10 \mathrm{mM} \mathrm{pH} \mathrm{8;} \mathrm{EDTA} 1$ $\mathrm{mM}$ ) hasta alcanzar 17,72 g. Se equilibraron los pesos de los tubos, se sellaron con Parafilm ${ }^{\circledR}$ y se mantuvieron en agitación suave durante al menos $1 \mathrm{~h}$ a temperatura ambiente para disolver la mezcla, que se transfirió muy lentamente con una pipeta Pasteur, a tubos de ultracentrífuga de $12 \mathrm{ml}$. Se añadió parafina y una vez comprobada la ausencia de aire se sellaron por calor. Los tubos equilibrados se centrifugaron a 41.000 r.p.m. en la ultracentrífuga Beckman $®$ L8$70 \mathrm{M}$ (rotor $70.1 \mathrm{Ti}$ ) durante $20^{\circ} \mathrm{C}$ y $40 \mathrm{~h}$. En esta centrifugación el ADN genómico se separó en el gradiente de otras moléculas como el ARN (que queda en el fondo del tubo), polisacáridos (una banda que se observa con luz blanca). El ADN se visualizó bajo luz ultravioleta (con longitud de onda larga para dañar menos el ADN) como una banda intermedia gracias a la bis-benzimida, un agente intercalante similar al bromuro de etidio pero menos peligroso. La banda correspondiente al ADN genómico fue retirada mediante una jeringuilla con aguja de calibre grueso $(1,8 \mathrm{~mm})$ y transferida a tubos de $10 \mathrm{ml}$. El ADN purificado se limpió varias veces, mediante agitación muy suave, con nbutanol saturado con agua para eliminar la bis-benzimida, y fue dializado a $4{ }^{\circ} \mathrm{C}$ frente a tampón TNE (10 mM Tris- $\mathrm{HCl} \mathrm{pH} 8 ; 1 \mathrm{mM}$ EDTA; 0,1 M NaCl), TE y agua destilada (2 cambios). Finalmente fue distribuido en alícuotas de $1 \mathrm{ml}$ y almacenado a $4{ }^{\circ} \mathrm{C}$.

\subsubsection{2 - Método CTAB}

Para obtener el ADN total de $F$. oxysporum a menor escala (5-10 $\mu \mathrm{g}$ de ADN) se siguió el protocolo de Möller y colaboradores (Moller et al., 1992). Se inocularon $50 \mathrm{ml}$ de medio PDB con un fragmento de micelio congelado en glicerol y se incubó a $25^{\circ} \mathrm{C}$ y 120 r.p.m., 5-7 días. El micelio se filtró a través de dos gasas estériles y fue pulverizado en un mortero con nitrógeno líquido. Se repartió en tubos de 1,5 $\mathrm{ml}$ en fracciones de $300 \mathrm{mg}$ como máximo. A continuación se añadieron $500 \mu \mathrm{l}$ de una solución de lisis (100 mM TrisClH pH 8,0; 10 mM EDTA, $2 \%$ SDS) y 50-100 $\mu \mathrm{g}$ de proteinasa $\mathrm{K}$. Se incubó a $55-60^{\circ} \mathrm{C}$ durante 1 hora mezclando ocasionalmente con suavidad. Pasado este tiempo se ajustó la concentración salina mediante la adición de $140 \mu \mathrm{l}$ de $\mathrm{NaCl} 5 \mathrm{M}$; se añadieron 1/10 volúmenes $(65 \mu \mathrm{l})$ de CTAB (bromuro de hexadeciltrimetilamonio) al $10 \%$ y los tubos se incubaron a $65^{\circ} \mathrm{C}$ durante $10 \mathrm{~min}$.

Se añadió un volumen $(700 \mu l)$ de SEVAG (24 cloroformo: 1 alcohol isoamílico), se mezcló suavemente invirtiendo los tubos 
varias veces y estos se mantuvieron en hielo durante $30 \mathrm{~min}$. Tras este periodo se centrifugaron a $4{ }^{\circ} \mathrm{C}$ y 13.000 r.p.m. durante 5 min. El sobrenadante fue transferido a tubos nuevos y se les añadió $225 \mu \mathrm{l}$ de acetato amónico $5 \mathrm{M}$. Se mezcló con cuidado y se mantuvo en hielo un mínimo de $30 \mathrm{~min}$.

Se volvió a centrifugar en las mismas condiciones y el sobrenadante se transfirió a tubos nuevos y se añadieron $5 \mu$ de RNAsa A $10 \mathrm{mg} / \mathrm{ml}$ (Roche), se mantuvieron en incubación a $37{ }^{\circ} \mathrm{C}$ y $1 \mathrm{~h}$. Se repitió la centrifugación y se transfirió el sobrenadante a nuevos tubos. Para precipitar el ADN se añadieron 0,55 volúmenes $(510 \mu \mathrm{l})$ de isopropanol y se mantienen los tubos en hielo durante 15-30 min. En este paso suele verse el ADN formando un "ovillo" o "nube". Tras la incubación se realizó una centrifugación a 13.000 r.p.m. durante $15 \mathrm{~min}$. Se eliminó el sobrenadante y el precipitado se lavó dos veces con etanol $70 \%$ frío. Tras secar con vacío en Speed Vac el ADN fue resuspendido en $50 \mu \mathrm{l}$ de agua estéril.

\subsubsection{3 - Método TENSP}

Al igual que el método del CTAB se utiliza para obtener ADN limpio y poco degradado.

Se machacó el micelio en un mortero con nitrógeno líquido y se recogió en tubos de $1,5 \mathrm{ml}$ a los que se añadieron $600 \mu \mathrm{l}$ de la solución de lisis TENSP (TrisHCl pH 8, 100 mM; EDTA 50 mM; $\mathrm{NaCl}$ 0,5 M; SDS $2 \%$; PVP $1 \%$; $\beta$-mercaptoetanol $10 \mathrm{mM})$. Se mezcló para homogeneizar y se incubó a 65
${ }^{\circ} \mathrm{C}$ durante $30 \mathrm{~min}$. Se agitó nuevamente en medio de la incubación. Se añadieron $500 \mu \mathrm{l}$ de cloroformo: alcohol isoamílico (24:1) mezclando suavemente. Se centrifugó a 10.000 r.p.m. durante 5 min. El sobrenadante $(500 \mu \mathrm{l})$ se transfirió a un tubo nuevo y se añadió un volumen de fenol: cloroformo: isoamílico $(25: 24: 1)$ y se centrifugó a 10.000 r.p.m. durante $5 \mathrm{~min}$. Se repitió este paso. Se procedió a otra extracción cloroformo: isoamílico (24:1), agitando en vórtex y centrifugando según las condiciones anteriores. Tras repetir este paso se transfirió el sobrenadante a un tubo nuevo, se añadieron 0,7 volúmenes de isopropanol (o bien 2,5 volúmenes de Etanol absoluto). Se guardó varias horas a $-20^{\circ} \mathrm{C}$. Después se centrifugó a $4{ }^{\circ} \mathrm{C}$ y 14.000 r.p.m. durante 20 minutos, para precipitar el ADN. Se desechó el sobrenadante y se lavó el precipitado con etanol 70 \%. Se centrifugó a 14.000 r.p.m. y 5 min y se dejó secar al aire o bien mediante un sistema de vacío. Una vez seco se resuspendió en un volumen de $100 \mu \mathrm{l}$ de agua a los que se añadió $1 \mu$ l de ARNsa A (50 $\mu \mathrm{g} / \mathrm{ml})$.

\subsubsection{4 - Método rápido a partir de cultivo en placa}

Otro procedimiento más rápido para obtener ADN a pequeña escala, preferentemente para su utilización como molde en la PCR, es el modificado por DíazMínguez del original descrito por DuTeau (DuTeau \& Leslie, 1991).

Se preparó un cultivo en placa con medio PDA de la estirpe elegida. Se incubó a 
22-28 ${ }^{\circ} \mathrm{C}$ hasta obtener una colonia de 2-3 $\mathrm{cm}$ de diámetro. El micelio de la colonia se raspó con un bisturí procurando no tomar fragmentos de agar y se transfirió a un tubo de 1,5 ml. A continuación se llenó el tubo que contiene el micelio con nitrógeno líquido y se dejó que evaporase. Se repitió el proceso para añadir inmediatamente después el tampón de lisis (Tris $\mathrm{HCl} 50 \mathrm{mM} \mathrm{pH}$ 8,0, EDTA 50 mM, SDS $3 \%$, $\beta$-mercaptoetanol 1 $\%$, proteinasa $\mathrm{K} 0,1 \mathrm{mg} / \mathrm{ml}$ ) calentado a 65 ${ }^{\circ} \mathrm{C}$. Se mezcló en vórtex y se incubó la mezcla a $65^{\circ} \mathrm{C}$ durante $40 \mathrm{~min}$. La agitación se repitió en la mitad de la incubación.

Se añadieron $0,5 \mathrm{ml}$ de fenol equilibrado y se centrifugó a 8.000 r.p.m. durante $5 \mathrm{~min}$, para separar las fases. Se tomaron $0,4 \mathrm{ml}$ de la fase acuosa y se mezclaron con 0,4 $\mathrm{ml}$ de cloroformo: alcohol isoamílico (24:1). Se separaron las fases mediante una nueva centrifugación y se transfirió la fase acuosa a un tubo limpio. Se añadieron $75 \mu \mathrm{l}$ de acetato amónico $5 \mathrm{M}$, mezclándose suavemente y a continuación se añadieron 0,9 $\mathrm{ml}$ de etanol absoluto. Cuando en este paso se observaron hebras de ADN se recogieron con una pipeta cuya punta estaba cortada en el extremo. Cuando no fue así se incubaron los tubos a $-80^{\circ} \mathrm{C}, 30 \mathrm{~min}$ y se centrifugó a 14.000 r.p.m. y 15 min., para precipitar el ADN.

El precipitado se lavó con etanol al 70 \% para eliminar sales y se secó al vacío. El ADN se resuspendió en 50 de $\mu$ de agua destilada estéril y se utilizó $1 \mu \mathrm{l}$ como molde por cada reacción de PCR. Cuando hubo problemas de amplificación se procedió a hacer diluciones del ADN.

\subsubsection{5 - Minicolumnas EZNA}

Es un método rápido que se utilizó para obtener ADN que se utilizó como molde en la PCR. Tanto las minicolumnas como los reactivos están incluidos en el "Ezna Plant Miniprep Kit" (Omega Biotek, Doraville, USA). Se siguió el procedimiento aconsejado por el fabricante.

\subsection{2 - ADN de plásmidos}

Las estirpes bacterianas transformadas con los plásmidos correspondientes fueron inoculadas en medio LB o 2xTY más el antibiótico adecuado, e incubadas a $37^{\circ} \mathrm{C}$ durante aproximadamente 8 horas.

\subsubsection{1 - Lisis alcalina}

Este método (Sambrook et al., 1989) permite obtener cantidades de plásmido superiores a los $10 \mu \mathrm{g}$. Se inoculó con una colonia en 1,5-3 $\mathrm{ml}$ de medio LB más el antibiótico correspondiente. Se incubó el cultivo toda la noche a $37^{\circ} \mathrm{C}$ con agitación. Se recogieron las células por centrifugación en un tubo de $1,5 \mathrm{ml}$ y se eliminó el medio de cultivo. Las células se resuspendieron en 100 $\mu \mathrm{l}$ de solución 1 (glucosa $50 \mathrm{mM}$, Tris- $\mathrm{HCl} 25$ $\mathrm{mM} \mathrm{pH}$ 8,0, EDTA $10 \mathrm{mM}$, ARNasa A 10 $\mathrm{mg} / \mathrm{ml}$, mantenida a $4^{\circ} \mathrm{C}$ ). 
Tras 5 min a temperatura ambiente se añadieron $200 \mu \mathrm{l}$ de solución $2(\mathrm{NaOH}$ 0,2 N, SDS $1 \%$ ), se mezcló varias veces por inversión, y se mantuvo 5 minutos en hielo. Finalmente se añadieron $150 \mu \mathrm{l}$ de acetato sódico $3 \mathrm{M}$ y pH 5,2; la suspensión se mezcló de nuevo por inversión y se mantuvo $10 \mathrm{~min}$ en hielo. La eliminación de ADN genómico y de restos celulares se realizó por centrifugación a velocidad máxima durante $10 \mathrm{~min}$. El sobrenadante se traspasó a un nuevo tubo y el ADN plasmídico se precipitó con 2 volúmenes de etanol $100 \%$ frío y se lavó 2 veces con etanol 70 \%. Una vez secado al vacío el precipitado se resuspendió en $50 \mu$ de agua destilada estéril.

\subsubsection{2 - "High Pure Plasmid Isolation Kit" y "Fastprep Eppendorf Kit"}

Cuando se requirió un alto grado de pureza del ADN plasmídico (construcciones y secuenciaciones) se utilizaron los kits de minicolumnas comerciales "High Pure Plasmid Isolation Kit" (Roche) o "FastPrep" (Eppendorff®) a partir de cultivos de 5-10 ml, siguiendo las instrucciones del fabricante.

\subsubsection{3 - Lisis de colonias o "cracking"}

Este método (Le Gouill \& Dery, 1991) es conveniente cuando se trata de analizar un número elevado de colonias y cuando el tamaño del inserto es significativamente superior al del vector.

Se añadieron $40 \mu \mathrm{l}$ de una solución de lisis (SDS $10 \% 100 \mu \mathrm{l}$; $\mathrm{NaOH} 10 \mathrm{~N} 10 \mu \mathrm{l}$;
TrisHCl 1 M $10 \mu \mathrm{l}$; EDTA 0,5 M $20 \mu \mathrm{l}$ y $860 \mu \mathrm{l}$ de agua destilada estéril para un volumen de $1 \mathrm{ml}$ ) en tantos tubos de $1,5 \mathrm{ml}$ como colonias a analizar. Se tomó una colonia con un palillo estéril, se hizo una réplica en placa y se resuspendió el resto de la colonia en la solución de lisis. Se dejó a temperatura ambiente durante $15 \mathrm{~min}$.

En este tiempo se preparó una mezcla con $3 \mu \mathrm{l}$ de $\mathrm{HCl} 1 \mathrm{~N}$ y $5 \mu \mathrm{l}$ de tampón de carga (azul bromo-fenol 0,5\%; Xileno cianol $0,25 \%$; glicerol $30 \%$ ó Ficoll 15\%) (Sambrook et al., 1989) y se añadieron $8 \mu \mathrm{lde}$ esta mezcla a cada tubo. Se mantuvieron a $80{ }^{\circ} \mathrm{C}$ durante $20 \mathrm{~min}$. Tras este tiempo se centrifugaron a 13.000 r.p.m. durante $15 \mathrm{~min}$ para sedimentar restos celulares y se puso inmediatamente en hielo.

Se utilizaron $30 \mu$ para visualizar el ADN en un gel de agarosa-TAE al 0,8\%. En el gel se pueden apreciar las diferencias entre las colonias transformadas por el vector con y sin inserto. Una vez localizadas aquellas de interés se recuperó el plásmido a partir de las copias de la placa utilizando uno de los métodos descritos anteriormente.

\subsection{3 - ARN total}

\subsubsection{1 - Método "TRI-REAGENT"}

Se añadió $1 \mathrm{ml}$ de TRI Reagent (Molécular Research Center, Inc) para 50-100 mg de material pulverizado en mortero con nitrógeno líquido. Se homogenizó en "vortex" y se incubó a temperatura ambiente durante 5 min. Para eliminar posibles contaminantes 
como polisacáridos y ADN se centrifugó el homogeneizado a $4{ }^{\circ} \mathrm{C}$ y 12.000 r.p.m. durante $10 \mathrm{~min}$.

Se transfirió el sobrenadante a un tubo nuevo y se le añadió $0,2 \mathrm{ml}$ de cloroformo, se mezcló enérgicamente en "vortex" y se mantuvo a temperatura ambiente durante 10-15 min. Tras este tiempo se centrifugó a $4{ }^{\circ} \mathrm{C}$ y 12.000 r.p.m. durante $15 \mathrm{~min}$. Se transfirió la fase acuosa a un nuevo tubo y se añadieron $0,5 \mathrm{ml}$ de isopropanol, se mezcló por inversión y tras 510 min a temperatura ambiente, se centrifugó a $4{ }^{\circ} \mathrm{C}$ y 12.000 r.p.m. durante $8 \mathrm{~min}$. El precipitado se lavó con $1 \mathrm{ml}$ de etanol $70 \%$ y se centrifugó a $4{ }^{\circ} \mathrm{C}$ y 12.000 r.p.m. durante 5 min. El ARN precipitado se secó al aire durante 5-10 min y se disolvió en agua estéril tratada con DEPC incubándolo a $55-60^{\circ} \mathrm{C}$ durante $10 \mathrm{~min}$.

\subsubsection{2 - Minicolumnas "RNeasy"}

Es un kit (casa comercial QIAGEN) que usa minicolumnas que permiten una extracción rápida del ARN a partir de micelio de hongo o de tejido de planta sin residuos de ADN genómico.

\subsection{4 - ARN mensajero (poliA)}

\subsubsection{Kit "OLIGOTEX QIAGEN"}

Cuando se requirió una elevada concentración de ARN mensajero en la muestra se usaron las minicolumnas "Oligotex" (casa comercial QIAGEN).

\subsection{5 - ADN complementario (ADNc)}

Se comprobó la presencia de ADN genómico residual en el aislamiento de ARN total mediante una PCR con oligonucleótidos conocidos. Cuando fue necesario realizar un tratamiento con ADNasa para eliminar el ADN genómico que pudiera estar contaminando la muestra, se usaron dos kits siguiendo las instrucciones de los fabricantes.

ADNasa de Promega: Actúa a $37^{\circ} \mathrm{C}$ y se elimina mediante fenolización y posterior precipitación con acetato sódico y etanol absoluto. ADNasa de Ambion: Actúa a $37^{\circ} \mathrm{C}$ $y$ se elimina con una resina mediante centrifugación.

\subsection{6 - Cuantificación de ácidos nucleicos}

Para estimar la pureza y concentración del ADN y el ARN, se midió la absorbancia. La cuantificación se realizó por espectrofotometría a 260 y $280 \mathrm{~nm}$ mediante un Nanodrop (Thermo Scientific).

La pureza del ADN puede estimarse aproximadamente midiendo la razón A260/A280, absorbancias máximas del ADN y de las proteínas, respectivamente. EI ADN puro de $E$. coli tiene una razón de 1,8 A, aunque este valor depende de la composición de bases y puede variar según los organismos. Para el ARN el valor obtenido en una preparación pura es 2,0 A. 
La cantidad e integridad de las muestras también se puede estimar mediante electroforesis en geles de agarosa (0,6 \% para ADN genómico y $1 \%$ para el ARN), calculando el tamaño y cantidad con referencia a concentraciones conocidas de marcadores de peso molecular.

\section{6 - Plásmidos}

\subsection{1 - Vectores de clonación PGEM-T y PGEM-T- Easy}

Estos vectores tienen un tamaño de aproximadamente $3 \mathrm{~kb}$ y se comercializan lineales. Tienen una desoxitimidina 3' terminal en ambos extremos, característica que mejora la eficiencia de clonación de productos de PCR, ya que las polimerasas termoestables frecuentemente añaden una única desoxiadenosina en los extremos 3' de los fragmentos amplificados. Poseen el origen de replicación del bacteriófago filamentoso f1. El vector pGEM-T-Easy se diferencia del vector pGEM-T, principalmente, por poseer un sitio EcoRI y un sitio Notl a cada lado del lugar de clonación.

\subsection{2 - pJJWA}

El plásmido pJJWA es un plásmido binario construido a partir del plásmido p302.

p302 contiene los genes de virulencia necesarios para el proceso de infección de $A$. tumefaciens y la resistencia a la kanamicina como marcador de selección. Así mismo, contiene las regiones de reconocimiento para la inserción conocidas como Left Border (LB) y Right Border (RB). Entre estas regiones se sitúa un punto de reconocimiento de la enzima de restricción $\mathrm{Ncol}$ precedida del promotor del gen ToxA de Pyrenophora triticirepentis.

Para la construcción del plásmido pJJWA el vector p302 fue linealizado por el sitio Ncol. En paralelo, se diseñaron tres oligonucleótidos distintos. Uno en sentido y común a las dos PCR (S62), incluyendo el sitio reconocido por $\mathrm{Ncol}$, para poder unirse al plásmido linealizado. Los otros dos (A64 y A65) en antisentido e incluyendo un sitio de reconocimiento Notl (de 8 bp de longitud), pero diferenciándose por anillar en el gen de interes en puntos separaros por $100 \mathrm{bp}$. La longitud final de los fragmentos son 450 bp y $550 \mathrm{bp}$.

Se realizó una ligación de los tres fragmentos y se verificó el producto de ligación mediante la digestión con Notl y Ncol.

\subsection{2-pS3}

Se trata de una construcción realizada en trabajos previos en nuestro laboratorio. Es un plásmido binario derivado del plásmido usado en hongos pDHt1 que a su vez deriva 
del plásmido diseñado para plantas pCAMBIA1300 (Cambia. EEUU).

El plasmido pS3 contiene el gen de resistencia bacteriana a la kanamicina y las regiones de reconocimiento de $A$. tumefaciens al igual que pCAMBIA1300, así como el gen hph (hygromycin B phosphotransferase) de resistencia a higromicina bajo el control promotor del gen TrpC de A. nidulans.

\section{7 - Manipulación de ácidos nucleicos}

\subsection{1 - Tratamiento con enzimas de restricción}

Todas las reacciones enzimáticas fueron realizadas en presencia del tampón correspondiente a la concentración final adecuada (1X) (suministrado por la casa comercial a concentración 10X). Los tratamientos de ADN, tanto genómico como plasmídico, con endonucleasas de restricción se realizaron rutinariamente para la caracterización física de los plásmidos y fragmentos de ADN y para la construcción de plásmidos recombinantes. El tipo de tampón utilizado, la concentración de sales y las condiciones específicas de incubación se ajustaron a las instrucciones de la casa comercial (Roche o Promega). Las digestiones se llevaron a cabo durante tiempos y con cantidades de enzima variables dependiendo de la pureza y la cantidad de ADN a tratar. Como norma general, el volumen de la enzima no superó 1/10 del volumen total de reacción, debido a la alta concentración de glicerol en las soluciones de almacenamiento, que podría inhibir la propia actividad enzimática.
Cuando el ADN debía ser tratado con varias endonucleasas de restricción de forma sucesiva (no al mismo tiempo, por carecer de buena actividad en un mismo tampón), el ADN digerido con la primera de las enzimas fue purificado por minicolumna comercial (Geneclean Turbo o NucleoSpin de Macherey-Nagel) y sometido a una nueva digestión con la siguiente enzima. Las digestiones totales se llevaron a cabo durante al menos $1 \mathrm{~h}$. Las digestiones parciales, en las que se pretende obtener un rango de tamaño digerido determinado, se realizaron ajustando los tiempos y concentraciones de muestra y enzima, según el caso. En ambos casos, los tamaños de los fragmentos digeridos se visualizaron en geles de agarosa utilizando marcadores de tamaño conocidos como ADN del fago $\lambda$ digerido con las enzimas HindIII y EcoRl o patrones de tamaños estandarizados de las casas BioRad o Biotools.

\subsection{2 - Defosforilación con Fosfatasa Alcalina}

Se usó fosfatasa alcalina de camarón (SAP, Shrimp Alkaline Phosphatase) de 
Promega, siguiendo las instrucciones del fabricante. Se caracteriza por inactivarse completamente sometiéndola a $65^{\circ} \mathrm{C}$ durante 15 minutos. Tras centrifugar el sobrenadante se usó directamente para ligación.

\subsection{3 - Ligaciones}

Se usaron las ligasas de Roche y Promega siguiendo las instrucciones de los fabricantes, según se tratase de ligaciones de extremos romos o sobresalientes. La primera se utilizó a $16^{\circ} \mathrm{C}$ durante varias horas y tampón 10X y la segunda para ligaciones rápidas a $22{ }^{\circ} \mathrm{C}, 1 \mathrm{~h}$ y tampón $2 \mathrm{X}$. Las reacciones se llevaron a cabo generalmente en un volumen de 5-10 $\mu$ l.

\subsection{4 - Recuperación de ADN a partir de soluciones}

Precipitación con 0,1 volúmenes de 3 $\mathrm{M}$ acetato amónico $\mathrm{pH}$ 5,2 más 2,5 volúmenes de etanol absoluto. Tras mezclar la muestra se mantuvo a $-20{ }^{\circ} \mathrm{C}$ durante al menos $1 \mathrm{~h}$. Se precipitó centrifugando a $4^{\circ} \mathrm{C}$ y 14.000 r.p.m. durante $15 \mathrm{~min}$. El precipitado se lavó con etanol al $70 \%$, y tras secar al vació fue resuspendido en agua destilada estéril.

Minicolumnas NucleoSpin Extract II (Macherey-Nagel) El ADN se une a la membrana de la columna permitiendo el lavado del resto de componentes. Posteriormente se resuspende el ADN separándolo de la membrana.

Geneclean Turbo kit (Q-Bio Gene), minicolumnas que retienen el ADN y permiten obtenerlo libre de sales, según las instrucciones del fabricante.

\subsection{5 - Secuenciación de ADN}

La secuenciación se llevó a cabo en el Servicio de Secuenciación Automática de la Universidad de Salamanca, en el que se empleó el secuenciador ABI PRISM 377 (Applied Biosystems, PE) y que utiliza el procedimiento originalmente descrito por Sanger utilizando fluorocromos que son discriminados por un lector óptico. Los cromatogramas son visualizados con programas informáticos. Para la reacción se usaron 500-600 ng de ADN plasmídico purificado por minicolumnas comerciales y 3 pmol de oligonucleótido.

\section{8 - Electroforesis en geles de agarosa}

\subsection{1 - Electroforesis de ADN}

La electroforesis en geles de agarosa se realizó en cubetas horizontales en las que los geles, de tamaño variable, fueron sumergidos en un tampón de electroforesis. La concentración de agarosa en los geles varió entre 0,6 \% y $2 \%(\mathrm{w} / \mathrm{v})$ en función del tamaño de los fragmentos de ADN que se querían analizar. Tanto la preparación de los 
geles como el desarrollo de las electroforesis se llevaron a cabo en tampón TAE 1X (Trisacetato $40 \mathrm{mM}$, EDTA $1 \mathrm{mM})$.

Las muestras de ADN se mezclaron con tampón de carga de electroforesis (azul de bromofenol 0,25\% p/v, xilén cianol FF $0,25 \% \mathrm{p} / \mathrm{v}$, ficoll tipo $40015 \% \mathrm{p} / \mathrm{v}$ ) en proporción 5:1 (v/v). De esta forma se pudo seguir el estado de la electroforesis por la posición relativa de los colorantes del frente, que migran con un tamaño de ADN conocido. A continuación se aplicó un voltaje variable (entre 1 y 7,5 voltios/cm) dependiendo de la cantidad de ADN y del rango de tamaño que se pretendiera resolver.

Finalizada la electroforesis los geles se tiñeron en una solución de bromuro de etidio $(0,5 \mu \mathrm{g} / \mathrm{ml})$ en TAE $1 \mathrm{X}$. El bromuro de etidio se intercala entre los nucleótidos y permite visualizar los fragmentos de ADN al iluminar el gel con luz UV (260 ó 320 nm). Las concentraciones y tamaños de los fragmentos separados se estimaron por comparación directa con muestras patrón de tamaños conocidos que se incluían rutinariamente en los geles, como ADN del fago $\lambda$ digerido con las enzimas Hindlll y EcoRl o patrones de tamaños estandarizados de las casas BioRad o Biotools.

\subsection{2 - Recuperación de ADN a partir de}

fragmentos de agarosa

Para la recuperación de fragmentos de ADN separados por electroforesis en agarosa en ambos casos se parte de la disolución del fragmento de agarosa entorno a $60{ }^{\circ} \mathrm{C}$. Posteriormente se limpia y resuspende usando los siguientes procedimientos, siguiendo las instrucciones de los fabricantes:

Geneclean kit (Q-Bio Gene), empleando una resina que se une al ADN.

Minicolumnas (NucleoSpin Extract II de Macherey-Nagel), que requieren de una sola centrifugación del fragmento de agarosa. El ADN se une a la membrana de la columna permitiendo el lavado del resto de componentes. Posteriormente, se resuspende el ADN separándolo de la membrana.

\section{9 - Transformaciones}

\subsection{1 - Transformación de Escherichia colt}

\subsubsection{1 - Preparación de células}

electrocompetentes

Las transformaciones de $E$. coli se realizaron utilizando células competentes obtenidas según el método descrito por
Hanahan y colaboradores (Hanahan et al., 1991). Se realizó un preinóculo con una colonia de la cepa $\mathrm{DH} 5 \alpha$ de $E$. coli en $5 \mathrm{ml}$ de LB, que se incubó con agitación una noche a $37^{\circ} \mathrm{C}$. Dicho cultivo se utilizó para inocular, en un matraz de 2 I, un cultivo de 500 a 650 ml de medio $\phi$ (Psi: triptona 20 g; extracto de levadura $5 \mathrm{~g}$; $\mathrm{KCl} 0,75 \mathrm{~g} ; \mathrm{MgSO}_{4} 4 \mathrm{~g}$; Agua 
esteril hasta 1 litro. Se ajustó a $\mathrm{pH} 7,6$ con $\mathrm{KOH} 10 \mathrm{~N})$ que se incubó a $37^{\circ} \mathrm{C}$ con agitación vigorosa (250-300 r.p.m.) hasta que alcanzó una densidad óptica medida a 650 $\mathrm{nm}$ de 0,48 A. Las bacterias se recogieron por centrifugación a $4{ }^{\circ} \mathrm{C}$ y 2.500 r.p.m. durante $5 \mathrm{~min}$.

A continuación se resuspendieron en un $150 \mathrm{ml}$ del tampón TFB1 frío $\left(\mathrm{RbCl}_{2} 12,092\right.$ g/l; $\mathrm{MnCl}_{2}$ 6,28 g/l; acetato potásico 2,94 g/l; $\mathrm{CaCl}_{2} 1,09 \mathrm{~g} / \mathrm{l} ;$ y glicerol al $15 \% \mathrm{v} / \mathrm{v}$, ajustado a pH 5,8 con ácido acético 0,2 M y esterilizado por filtración) manteniéndolas en hielo y con una agitación manual suave hasta su completa resuspensión. Después de incubarlas en hielo durante 5 minutos, las células fueron centrifugadas a 2.000 r.p.m., 15 minutos a $4{ }^{\circ} \mathrm{C}$. Se resuspendieron en un volumen de $20 \mathrm{ml}$ de tampón TFB2 frío (MOPS 2,093 g/l; $\mathrm{RbCl}_{2}$ 1,209 g/l; $\mathrm{CaCl}_{2}$ 8,32 $\mathrm{g} / \mathrm{l}$ y glicerol al $15 \% \mathrm{v} / \mathrm{v}$ ajustado a $\mathrm{pH} 7$ con $\mathrm{NaOH}$ y esterilizado por filtración). Las células se incubaron en hielo durante $15 \mathrm{~min}$ y se distribuyeron en alícuotas de 10, 100 y $200 \mu \mathrm{l}$ que se almacenaron $\mathrm{a}-80^{\circ} \mathrm{C}$.

\subsubsection{2 - Procedimiento de choque térmico}

Para realizar transformaciones en las que se requería una elevada eficiencia de transformación se usaron alícuotas de 50 a $100 \mu \mathrm{l}$ de células competentes; éstas fueron descongeladas en hielo, y unos 10-200 ng de ADN (en un volumen no mayor que la cuarta parte del volumen de células) fueron añadidos. La mezcla fue mantenida en hielo durante 20 minutos tras los cuales se sometieron a un choque térmico de 2 minutos a $37^{\circ} \mathrm{C}$ y otros 2 minutos en hielo $\left(4^{\circ} \mathrm{C}\right)$. Se añadieron $500 \mu \mathrm{l}$ de medio LB y se incubaron con agitación moderada a $37^{\circ} \mathrm{C}$ durante 1 hora. Transcurrido este tiempo las células se inocularon sobre los medios sólidos selectivos. Las placas se incubaron una noche a $37 \quad{ }^{\circ} \mathrm{C}$. La frecuencia de transformación que se obtuvo con este método fue de $2-5 \times 10$ e8 transformantes por $\mu \mathrm{g}$ de ADN plasmídico.

Cuando no se necesitaban eficiencias de transformación demasiado elevadas se empleó un procedimiento de transformación rápida, consistente en añadir 1-2 $\mu$ de ADN plasmídico (1-100 ng) a 3-5 $\mu$ le células competentes descongeladas en hielo. La solución se mantuvo 1 minuto en hielo y seguidamente se sometió a un choque térmico idéntico al descrito previamente. Tras añadir $100 \mu$ l de medio LB la mezcla se extendió directamente sobre medio sólido selectivo. La frecuencia de transformación obtenida es mucho menor que con otros métodos, pero el número de colonias transformantes es suficiente para asegurar la introducción del plásmido en la estirpe deseada.

Para seleccionar los clones portadores de plásmidos recombinantes derivados de vectores de clonación que portan el inicio del gen lacZ de E. coli, capaz de $\alpha$-complementación en cepas bacterianas como DH5a (Sambrook et al., 1989), se extendió a cada placa de petri, IPTG $(80 \mu \mathrm{l}$ de solución $0,1 \mathrm{M})$ y X-Gal (40 $\mu$ lde una solución al $2 \%$ en $n, n$-dimetilformamida $(w / v))$ 
(inductor de la transcripción y substrato cromogénico de la enzima, respectivamente), antes de añadir la mezcla de transformación. El procesamiento del X-Gal produce una coloración azul, lo que indicaría ausencia de inserto en el sitio de clonación del vector, mientras que en los clones recombinantes no habría producción de enzima y el color de las colonias sería blanco.

\subsection{2 - Transformación de Agrobacterium}

tumefaciens

\subsubsection{1 - Preparación de células competentes}

Se inoculó una colonia de la cepa AGL-1 de $A$. tumefaciens en $100 \mathrm{ml}$ de LB más los antibióticos rifampicina $(25 \mu \mathrm{g} / \mathrm{ml})$ y carbenicilina $(100 \mu \mathrm{g} / \mathrm{ml})$. Se incubó toda la noche a $30{ }^{\circ} \mathrm{C}$ con agitación vigorosa (180200 r.p.m.). Al día siguiente se centrifugaron las células a 5.000 r.p.m., $5 \mathrm{~min}, 4^{\circ} \mathrm{C}$ y se resuspendió el precipitado con $1 \mathrm{ml}$ de glicerol al $10 \%$ frío y se repartieron en alícuotas de $40 \mu \mathrm{l}$ que se conservaron a -80 ${ }^{\circ} \mathrm{C}$.

\subsubsection{2 - Procedimiento de electroporación}

Para la electroporación se añadieron 50-200 ng de ADN (en volumen no mayor de $4 \mu \mathrm{l})$ a $40 \mu \mathrm{l}$ de células electrocompetentes. Se colocó la mezcla en una cubeta de electroporación fría. El pulso fue de 8-12 ms, $2.500 \mathrm{~V} ; 25 \mu \mathrm{FD}$ y $400 \Omega$. La mezcla se recuperó añadiendo $1 \mathrm{ml}$ de LB. Se mantuvo en agitación a temperatura ambiente durante
2-4 horas y después las células se extendieron en placas de LB más kanamicina (50 $\mu \mathrm{g} / \mathrm{ml})$. Tras dos ó tres días de incubación a $28{ }^{\circ} \mathrm{C}$ empezaron a verse las colonias transformantes.

3.9.3 - Transformación de F. oxysporum

\subsubsection{1 - Preparación de A. tumefaciens}

Se siguió el método de transformación del hongo mediante $A$. tumefaciens propuesto por Mullins y colaboradores (Mullins et al., 2001). Una vez seleccionada la colonia de $A$. tumefaciens portadora de nuestra construcción derivada del plásmido pDHt1, se cultivó en $5 \mathrm{ml}$ de Medio Mínimo (MM) más Kan50 (kanamicina $50 \mu \mathrm{g} / \mathrm{ml}$ ) durante 1-2 días, $28{ }^{\circ} \mathrm{C}$. Se midió la densidad óptica a 600 nm (DO600) en espectrofotómetro y se añadió la cantidad necesaria de Medio de Inducción (IM) que contenía acetosiringona (AS), un inductor de los genes de virulencia, más Kan50, hasta alcanzar la una DO600 de 0,15 . Se incubó durante 6 horas, $27^{\circ} \mathrm{C}, 180$ r.p.m. Mientras, se preparó una suspensión de esporas frescas de $F$. oxysporum en agua a una concentración de $10^{6}$ esporas $/ \mathrm{ml}$.

Se mezclaron $100 \mu \mathrm{l}$ de suspensión de esporas con $100 \mu \mathrm{l}$ de cultivo de bacterias y se extendió la mezcla sobre una membrana de nitrocelulosa $(0,45 \mu \mathrm{m}$ de poro) colocada en placas de Petri con Medio de Cocultivo. Estas placas se incubaron durante 2 días a temperatura ambiente (entre 22 y $27{ }^{\circ} \mathrm{C}$ ) buscando las condiciones adecuadas para que el hongo no crezca muy deprisa e inhiba 
el crecimiento de la bacteria, pues con esta se obtienen menos transformantes.

Pasado este tiempo y cuando se observó crecimiento del hongo, se transfirió la membrana a otra placa con Medio de Selección, que contiene higromicina B (75 $\mu \mathrm{g} / \mathrm{ml}$ ) y cefotaxima $200 \mathrm{nM}$, que inhibe el crecimiento de Agrobacterium. Se incubaron las placas durante 5-7 días a temperatura ambiente (entre $22-27^{\circ} \mathrm{C}$ ). En este tiempo se empezaron a ver colonias resistentes que fueron transferidas a nuevas placas con Medio de Selección más higromicina B (100 $\mu \mathrm{g} / \mathrm{ml}$ ) recortando la membrana con un bisturí. Se realizaron dos réplicas más en placas PDA higromicina B $100 \mu \mathrm{g} / \mathrm{ml}$.

\subsubsection{2 - Medios de cultivo}

Medio mínimo (MM): Para 100ml. Tampón K 1ml, tampón M-N 2 ml, $\mathrm{CaCl}_{2} 1 \%$ $100 \mu$, glucosa $20 \%(w / v) 1$ ml, $\mathrm{FeSO}_{4}$ 0,01\% $1 \mathrm{ml}$, elementos traza $500 \mu \mathrm{l}, \mathrm{NH}_{4} \mathrm{NO}_{3} 20 \%$ (w/v) $250 \mu \mathrm{l}$ y Kan50 $1 \mu \mathrm{l} / \mathrm{ml}$ (esta última se añade en el momento de usar).

Medio de inducción (IM): Para 100ml. Tampón K $1 \mathrm{ml}$, tampón $\mathrm{M}-\mathrm{N} 2 \mathrm{ml}$, $\mathrm{CaCl}_{2} 1 \% 100 \mu \mathrm{l}$, glucosa $20 \%$ (w/v) $500 \mu \mathrm{l}$, $\mathrm{NH}_{4} 250 \mu \mathrm{l}$, MES 1M $4 \mathrm{ml}$, glicerol $50 \% 1 \mathrm{ml}$.
Además se añade en el momento de usar: acetoseringona $40 \mathrm{mg} / \mathrm{ml}$ (en etanol abs.) (AS40) $250 \mu \mathrm{M}, \mathrm{FeSO}_{4} 100 \mu \mathrm{l}$, elementos traza $500 \mu \mathrm{l}$ y kanamicina $50 \mu \mathrm{g} / \mathrm{ml} \mathrm{0,1} \mathrm{ml}$.

Medio de cocultivo: Para 1 litro. Tampón K 10 ml, tampón M-N 20 ml, $\mathrm{CaCl}_{2}$ $1 \% 1 \mathrm{ml}, \mathrm{FeSO}_{4} \quad 0.01 \% 10 \mathrm{ml}$, preparado de elementos traza $5 \mathrm{ml}, \mathrm{NH}_{4} \mathrm{NO}_{3} 20 \%$ (p/v) 2,5 $\mathrm{ml}$, MES $1 \mathrm{M} 40 \mathrm{ml}$, glicerol 50\% $10 \mathrm{ml}$, glucosa 2M (20\%) $5 \mathrm{ml}$ y agar $15 \mathrm{~g} \mathrm{AS40} 1$ $\mathrm{ml}$.

Como medio de selección se uso PDA con higromicina a una concentración de $75 \mu \mathrm{g} / \mathrm{ml}$.

Tampón K: $\mathrm{K}_{2} \mathrm{HPO}_{4} 200 \mathrm{~g} / \mathrm{l} ; \mathrm{KH}_{2} \mathrm{PO}_{4}$ 145 g/l; pH 7.

Tampón M-N: $\mathrm{MgSO}_{4} \cdot 7 \mathrm{H}_{2} \mathrm{O} 30 \mathrm{~g} /$; $\mathrm{NaCl} 15 \mathrm{~g} / \mathrm{l}$.

Preparado de elementos traza: $\mathrm{ZnSO}_{4} \cdot 7 \mathrm{H}_{2} \mathrm{O} \quad(100 \quad \mathrm{mg} / \mathrm{l}) ; \quad \mathrm{CuSO}_{4} \cdot 5 \mathrm{H}_{2} \mathrm{O}$ (100mg/l; $\quad \mathrm{H}_{3} \mathrm{BO}_{3} \quad(100 \mathrm{mg} / \mathrm{l}) ; \quad \mathrm{MnSO}_{4} \cdot \mathrm{H}_{2} \mathrm{O}$ (100mg/l); $\mathrm{Na}_{2} \mathrm{MoO}_{4} \cdot 2 \mathrm{H}_{2} \mathrm{O}(100 \mathrm{mg} / \mathrm{l})$.

\subsection{0 - Reacción en cadena de la polimerasa (PCR)}

\subsection{1 - Oligonucleótidos}

Cuando se conocía la secuencia de determinados fragmentos amplificados de interés, se diseñaron oligonucleótidos específicos utilizando los programas Geneious (Biomatters) y VectorNTI Suite 10 (Invitrogen). El diseño de los mismos se basó en el criterio de la temperatura de anillamiento. Esto se consigue básicamente 
por aumento del tamaño del oligonucleótido. Para ello se establece un tamaño suficientemente grande y se seleccionan zonas donde, por sus bases, la temperatura de anillamiento es más alta. Una vez establecidas estas zonas se ajusta el tamaño del oligonucleótido y la posición exacta donde la temperatura sea la deseada. Los oligonucleótidos, además de cumplir las condiciones mencionadas, fueron analizados para evitar la formación de bucles en los mismos y la formación de dímeros consigo mismos o con otros oligonucleótidos.

Algunos principios generales a la hora de diseñar los oligonucleótidos son:

a) Seleccionar secuencias altamente conservadas en la familia de proteínas para diseñar los oligonucleótidos.

b) Elegir la mínima degeneración. Los fragmentos que contienen metionina $\mathrm{O}$ triptófano son muy adecuados ya que son codificados por codones únicos. Por el contrario, fragmentos ricos en leucina, arginina o serina, codificados por 6 codones, respectivamente, pueden incrementar la degeneración del oligonucleótido.

c) Estudiar el uso preferencial de codones del organismo sobre el que trabajamos. Estadísticamente no todos los posibles tripletes que pueden codificar un aminoácido son utilizados con la misma frecuencia. Algunos de esos tripletes apenas se emplean y pueden ser despreciados.

El extremo 3' del oligonucleótido es el más importante a la hora de conferir la máxima especificidad a éste. Hay que procurar que sea lo menos degenerado posible.

En general, a menor temperatura de anillamiento se produce una mayor amplificación inespecífica, dependiendo de la degeneración de los oligonucleótidos.

La introducción de sitios de restricción se utilizó para facilitar la clonación en los diferentes vectores cuando no disponíamos de los sitios de reconocimiento de las enzimas de interés en nuestra secuencia. Una vez que el programa informático nos definió un par de oligonucleótidos con las características apropiadas, se buscó en la zona 5' del oligonucleótido una secuencia semejante a la secuencia palindrómica del sitio de reconocimiento de la enzima para intentar modificar lo menos posible la secuencia original.

\subsection{2 - Métodos de amplificación utilizados}

\subsubsection{1 - PCR}

Este procedimiento, desarrollado por Kary Mullis y sus colaboradores (Saiki et al., 1985), permite amplificar fragmentos de ADN a partir de un ADN molde en un proceso cíclico para generar un gran número de copias idénticas. En estos experimentos se usaron como cebadores dos oligonucleótidos correspondientes a los extremos 5' de las dos cadenas del fragmento de ADN que se desea amplificar. Las muestras de ADN utilizadas como molde junto con los cebadores correspondientes se sometieron a una serie de ciclos de desnaturalización, 
anillamiento o hibridación y extensión del cebador por acción de una ADN polimerasa termoestable, resultando en la amplificación del ADN de interés, cuyos extremos quedan definidos por la secuencia de los dos cebadores utilizados. Las amplificaciones se realizaron en un volumen de 10 a $100 \mu \mathrm{l}$ siguiendo las indicaciones de utilización de las diferentes enzimas que se usaron para este tipo de experimentos: AmpliTaq Gold (Applied Biosystems), Polimerasa (Biotools) o Expand Long Template (Roche). Las reacciones fueron llevadas a cabo en un termociclador GeneAmp PCR System 2.400 y GeneAmp PCR System 9.700 (Applied Biosystems), y los productos obtenidos fueron analizados por electroforesis en geles de agarosa.

El ciclo estandar de amplificación consistió en un paso inicial de $94^{\circ} \mathrm{C}$ durante 5 minutos, seguido de 30 ciclos de tres pasos: desnaturalización $\left(1 \min\right.$ a $\left.94^{\circ} \mathrm{C}\right)$, hibridación $\left(1 \mathrm{~min}\right.$ a $\left.58-60^{\circ} \mathrm{C}\right)$ y elongación $\left(72^{\circ} \mathrm{C}\right.$ y $1 \mathrm{~min}$ por cada 1 kb de amplicón). Finalmente, un paso final de $72^{\circ} \mathrm{C}$ y $7 \mathrm{~min}$.

\subsubsection{2 - PCR de gradiente}

La PCR de gradiente está basada en la utilización de termocicladores capaces de aplicar distintas temperaturas a cada columna del bloque (el utilizado en este trabajo es el MasterCycler Gradient de Eppendorf). Esto permitió analizar la temperatura óptima a la que se producía amplificación de ADN, utilizando una pareja determinada de oligonucleótidos y como molde distintos ADN genómicos homólogos (pertenecientes al organismo en el que se diseñaron los oligonucleótidos) y heterólogos (pertenecientes a otro organismo distinto al que se diseñaron los oligonucleótidos).

\subsubsection{3 - Transcripción inversa (RT-PCR)}

Con esta técnica se puede amplificar una cantidad pequeña de moléculas de ARN, tanto ARN mensajero (ARNm) como ARN total, con gran especificidad, mediante la transcripción inversa del ARN a ADN (ADNc), que es posteriormente amplificado.

Hay dos partes diferenciadas en cualquier RT-PCR: la transcripción inversa $(R T)$, en la que el ARN molde es copiado a ADN complementario o copia (ADNc) utilizando la enzima transcriptasa inversa. El ADNc es luego amplificado exponencialmente por PCR (en nuestro caso, normalmente PCR cuantitativa en tiempo real).

En la primera parte (RT), la enzima utilizada fue la SuperScript II Reverse Transcriptase (Invitrogen) o RetroTools Two Step (Biotools). Se utilizó como cebador el oligonucleótido (dT) ${ }_{15}$ (Biotools) que se une a las colas poliA de los ARNm. Si los oligonucleótidos utilizados flanquean un intrón, es decir, son complementarios de dos exones contiguos en el ARNm, se puede diferenciar fácilmente entre productos procedentes de ARNm y productos procedentes de $A D N$ genómico contaminante según su tamaño.

Con el kit de Biotools, el protocolo estandar para un volumen de reacción de 20 
$\mu \mathrm{l}$ es entre $1 \mathrm{ng}$ y $5 \mu \mathrm{g}$ de ARN (normalmente 2,5 $\mu \mathrm{l}$ de la elución del kit de extracción de ARN) , $1 \mu$ de oligonucleótido (dT) ${ }_{15} 50$ mM, 1 $\mu \mathrm{l}$ de mezcla de dNTPs $(10 \mathrm{mM}), 4 \mu \mathrm{l}$ de buffer de reacción $6 \mathrm{X}$ y $\mathrm{MnCl}_{2}$ y $1 \mu \mathrm{l}$ de enzima transcriptasa inversa; y agua destilada estéril tratada con DEPC hasta un volumen de $20 \mu \mathrm{l}$.

El ciclo estandar en el termociclador consistió en $42{ }^{\circ} \mathrm{C}$ durante $3-5 \min$ y $60^{\circ} \mathrm{C}$ durante $60 \mathrm{~min}$, en algunos casos se incluyó un tercer paso de desactivación si no se iba a usar inmediatamente el producto de $70^{\circ} \mathrm{C}$ durante $15 \mathrm{~min}$.

Si la concentración de ARN inicial era baja, se obtuvieron mejores resultados con un programa con varios ciclos denominado "RT-PCR cíclica": una primera etapa de $94^{\circ} \mathrm{C}$ durante $1 \mathrm{~min}$ seguida de 4 ciclos de dos pasos consistentes en $48^{\circ} \mathrm{C}$ durante 5 min y $60^{\circ} \mathrm{C}$ durante $15 \mathrm{~min}$.

Con el kit de Invitrogen, se usó el protocolo recomendado por el fabricante: Para un volumen de reacción de $20 \mu \mathrm{l}$ se usaron entre $1 \mathrm{ng}$ y $5 \mu \mathrm{g}$ de $\mathrm{ARN}$, se añadieron $1 \mu \mathrm{l}$ de oligo $(\mathrm{dT})_{15} 50 \mathrm{mM} ; 1 \mu \mathrm{lde}$ los 4 dNTP (10 mM cada uno), la cantidad necesaria de ARN y agua destilada estéril tratada con DEPC hasta un volumen de $12 \mu \mathrm{l}$. Se calentó la mezcla en el termociclador a 65 ${ }^{\circ} \mathrm{C}$ durante 5 min y se enfrió a $4{ }^{\circ} \mathrm{C}$ durante 2 minutos. A continuación se añadieron $4 \mu \mathrm{l}$ del tampón 5X "First-Strand Buffer", $2 \mu \mathrm{l}$ de DTT. Se incubó a $42{ }^{\circ} \mathrm{C}$ durante 2 min. Por último se añadió $1 \mu \mathrm{l}(200 \quad U)$ de la enzima transcriptasa inversa. Se incubó a $42{ }^{\circ} \mathrm{C}$ durante 50 min y se inactivó la reacción por calor (70 ${ }^{\circ} \mathrm{C}$ durante $15 \mathrm{~min}$ ).

\subsection{3 - Análisis del espaciador intergénico (IGS)}

de ADN ribosómico

El análisis del espaciador intergénico del ADN ribosómico se realizó mediante la amplificación del PCR de dicho espaciador y la digestión amplificado con distintas endonucleasas de restricción (apartado 3.7.1).

Los oligonucleótidos usados para la amplificación fueron CNL12 y CNS1 (Tabla 3. 1 - Pág. 60) (Appel \& Gordon, 1995). La amplificación siguió el protocolo estandar y se visualizó en un gel de agarosa.

Las endonucleasas de restricción probadas fueron: Accl, Apal, Aval, Avall, BamHI, Bglll, EcoRl, EcoRV, HindIII, Hpal, Mspl, Notl, Pstl, Pvull, Sacl, Sall, Scal, Smal, SnaBl, Spel, Sphl, Styl, Xbal y Xhol (AlvesSantos et al., 1999).

\subsection{4 - PCR cuantitativa (qPCR) a tiempo real}

\subsubsection{1 - Principios teóricos de la cuantificación por PCR a tiempo real}

La PCR cuantitativa a tiempo real permite controlar la cinética de la reacción de la PCR, de forma que los datos se recogen durante el proceso de la PCR y no al final, como sucede en la PCR convencional. Así, con este método se puede cuantificar la cantidad inicial del molde de la reacción en vez de la cantidad final del producto 
amplificado. La PCR a tiempo real controla la fluorescencia emitida durante la reacción como un indicador de la cantidad de la amplificación durante cada ciclo de PCR (Higuchi et al., 1992; Higuchi et al., 1993).

Cuando se muestra en escala logarítmica la cinética de la reacción de PCR a tiempo real, la amplificación del producto genera una curva característica. Esta curva de amplificación consiste en tres regiones distintas que caracterizan la progresión de la PCR:

Geométrica o exponencial, (detección para PCR a tiempo real). En cada ciclo se acumula el doble del producto inicial (asumiendo una eficiencia del $100 \%$ \%). La reacción es muy específica y precisa.

Lineal (alta variabilidad). En esta fase se consumen los componentes de la reacción, esta se torna más lenta y los productos comienzan a degradarse.

Meseta (punto final, detección en electroforesis según el método tradicional). La reacción se ha parado, se produce degradación de los productos amplificados.

Mientras la PCR progresa, en la fase exponencial, la amplificación ocurre exponencialmente, doblándose el producto
TAQMAN* PROBE-BASED ASSAY CHEMISTRY

1. Polymerization: A flucrescent reporter $(\mathbb{R})$ dye and a quencher (a) are attached to the $5^{\prime}$ and $3^{\prime}$ ends of a TaqMan" probe, respectively.

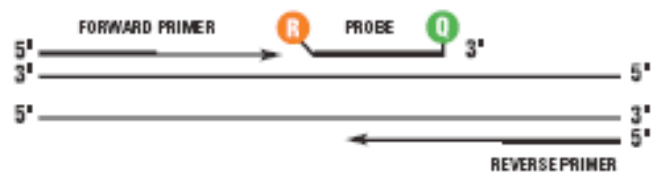

2. Strand displacement: When the probe is intact, the reporter dye emission is quenched.

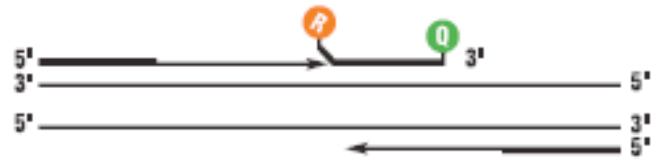

3. Cleavage: During each extension cycle, the DNA polymerase cleaves the reporter dye from the probe.

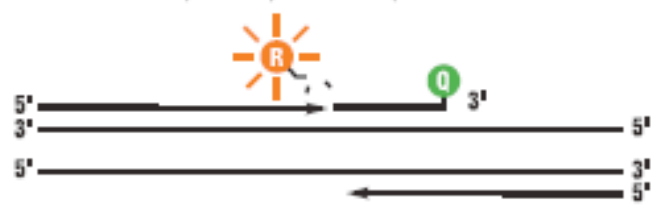

4. Polymerization completed: Once separated from the quencher, the reporter dye emits its characteristic fluorescence.

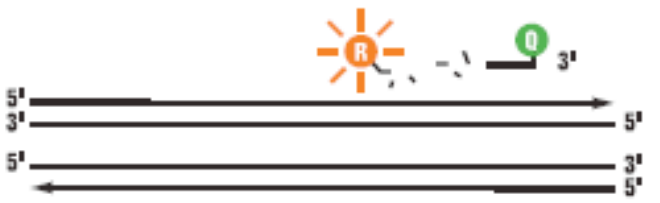

SYBR $^{*}$ GREEN I DYE ASSAY CHEMISTRY

1. Reaction setup: The SYBR* Green I Dye flucresces when bound to double-stranded DNA.

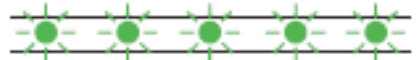

2. Denaturation: When the DNA is denatured, the SYBR* Green I Dye is released and the fluorescence is drastically reduced.

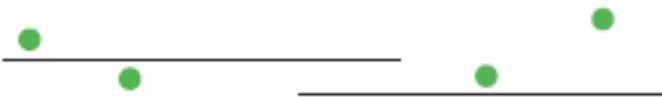

3. Polymerization: During extension, primers anneal and PCA product is generated.

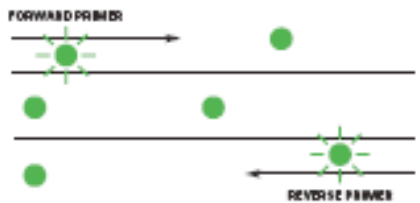

4. Polymerization completed: When polymerization is complete, $\mathrm{SYBR}^{*}$ Green I Dye binds to the double-stranded product, resulting in a net increase in fluorescence detected by the $7900 \mathrm{HT}$ system

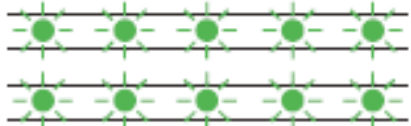

Figura 3. 1 - Comparación entre las técnicas de PCR cuantitativa en tiempo real usando sonda TaqMan o fluocromo SYBR Green. (Applied Biosystems). 
de partida en cada ciclo, esto ocurre porque hay abundancia de reactivos. En la Fase meseta, que es el área de detección de la PCR tradicional, los dNTPs ya han sido consumidos y la reacción se ralentiza. La línea threshold o umbral es el nivel de detección o el punto al que la reacción alcanza una intensidad de fluorescencia por encima del fondo o ruido espectral.

El procedimiento de PCR a tiempo real se basa en la detección y cuantificación de un emisor de fluorescencia (reporter) (Livak et al., 1995). Esta señal se incrementa en proporción directa a la cantidad del producto de PCR en la reacción. En el ordenador se registra la cantidad de emisión de fluorescencia en cada ciclo, así es posible controlar la reacción de PCR durante la fase exponencial donde el primer incremento significativo de la cantidad de producto de PCR se correlaciona directamente con la cantidad inicial de molde. Cuanto mayor sea el número de moléculas de partida del molde, mayor será el incremento en fluorescencia observado. Un incremento significativo en la fluorescencia por encima de un determinado umbral permite la detección del producto acumulado de la PCR.

Principalmente hay tres sistemas controlados por fluorescencia para la amplificación de ADN: (1) sondas de hidrólisis, que incluyen las sondas TaqMan (Applied Biosystems) y el marcaje Scorpion (Roche), (2) sondas de hibridación; y (3) agentes emisores de fluorescencia que se unen al surco menor del ADN de doble cadena (SYBR Green) (Applied Biosystems).

\subsubsection{2 - Sondas TaqMan}

Las sondas de hidrólisis, como TaqMan o TaqMan MGB, usan la actividad 5' exonucleasa de la Taq polimerasa para medir la cantidad de la secuencia objetivo en las muestras de ADNc. En nuestro caso utilizamos las sondas TaqMan y una variante de estas, las sondas TaqMan MGB. Las sondas TaqMan son oligonucleótidos más largos que los cebadores (20 ó 30 bases más largos con una $\mathrm{Tm}$ de unos $10^{\circ} \mathrm{C}$ mayor) que contienen un fluoróforo reporter (FAM, TET o VIC) sobre la base 5', y un fluoróforo quencher (TAMRA) sobre la base 3'. Los fluoróforos forman una pareja donadoraceptor, donde el donador es excitado y transfiere su energía a la molécula aceptora que está en su proximidad; a este fenómeno se le conoce como FRET: Transferencia de energía de excitación de Förster. (Fluorence Resonance Energy Tranfer). Así la proximidad del reporter y el quencher evita la emisión de fluorescencia mientras la sonda esté intacta. Las sondas TaqMan están diseñadas para hibridar en la región interna de un producto de PCR. Cuando la polimerasa replica una secuencia molde a la cual está unida una sonda TaqMan, su actividad 5' exonucleasa degrada la sonda. Esto frena la actividad del quencher (no produciendose el FRET) y el reporter comienza a emitir fluorescencia, la cual se incrementará en cada ciclo proporcionalmente a la hidrólisis de la sonda. La acumulación de los productos de PCR son detectados al controlar el incremento de 
fluorescencia del reporter. Los ensayos con sondas TaqMan utilizan los parámetros y condiciones de una reacción de PCR estándar. Como la degradación de la sonda ocurre sólo si está hibridando específicamente, el origen de esta fluorescencia es la amplificación específica. Un requerimiento específico para las sondas es que no haya una guanina en el extremo 5'. Una guanina adyacente al reporter capta la fluorescencia incluso antes de la degradación de la sonda.

Las sondas TaqMan MGB (Minor groove binding), son una variante de las descritas anteriormente. Presentan un reporter en el extremo 5' (FAM) y un quencher no fluorescente en el extremo 3' e incorporan además en ese mismo extremo un grupo MGB, cuya función es aumentar la Tm de la sonda sin incrementar la longitud de esta, permitiendo así el diseño de sondas más cortas.

\subsubsection{3 - Fluorocromo SYBR Green}

SYBR Green es un fluorocromo qe se une al surco menor del ADN de doble cadena y responde a la excitación por una fuente de luz. Sus ventajas son su facilidad, coste y rapidez de utilización, permite un trabajo dinámico con una variedad de muestras $y$ rangos de expresión variables. Una vez optimizada es posible reproducir los experimentos con gran rapidez simplemente diseñando nuevos oligonucleótidos. Otra diferencia entre los dos métodos es que las muestras diana y control endógeno van por separado.

El diseño de los oligonúcleotidos es un factor fundamental, $y$ hemos obtenido buenos resultados usando los parámetros para RT-PCR del programa informático Primer Express (Applied Biosystems).

Las principales desventajas del uso de esta técnica frente a la anterior es la posible unión del fluocromo a impurezas de la muestra o amplicones inespecíficos. La primera se descarta verificando que no hay restos de ADN genómico en la muestra. La segunda requiere un buen diseño de oligonucleótidos.

\subsubsection{4 - Ciclo umbral $\left(C_{T}\right)$}

Además de los cebadores y la sonda, en la mezcla de reacción se incorpora una "referencia pasiva", que es un marcador que permite normalizar la señal emitida por el reporter durante la recogida de datos, y corregir así fluctuaciones en la fluorescencia

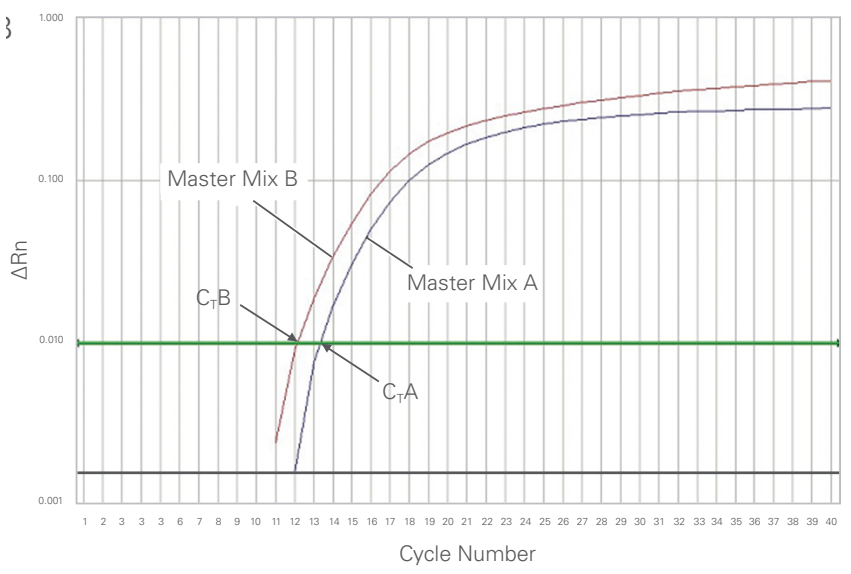

Figura 3. 2 - Gráfica mostrando el log(Rn) frente al número de ciclos para dos reacciones en las que se señala el umbral de detección $\left(\mathrm{C}_{T}\right)$ para un umbral definido (línea verde). 
debidas a cambios en la concentración o en el volumen de las diferentes reacciones.

El parámetro $\mathrm{Rn}$ se define como el cociente entre la intensidad de emisión del reporter y la intensidad de emisión de la referencia pasiva.

El parámetro $\mathrm{Rn}+$ define al parámetro $\mathrm{Rn}$ cuando la reacción incorpora moléculas del molde, mientras que $\mathrm{Rn}$ - es el valor de $\mathrm{Rn}$ en ausencia de molde $\mathrm{o}$ en los primeros ciclos de PCR, antes del incremento en la señal de fluorescencia.

La magnitud real de la señal generada durante un ensayo viene definida por incremento de $\mathrm{Rn}(\Delta \mathrm{Rn})$, que es la diferencia entre $R n+y$ Rn-.

Durante los primeros ciclos de la PCR se produce muy poco cambio en la señal de fluorescencia, obteniéndose la línea basal (baseline) para la curva de amplificación. Cuando se produce un incremento en la intensidad de fluorescencia se inicia el proceso de detección. Ligeramente por encima de esta basal puede fijarse un umbral de detección de fluorescencia (threshold). El parámetro $\mathrm{C}_{\mathrm{T}}$ (threshold cycle) o ciclo umbral se define como el ciclo de amplificación en el que tiene lugar este incremento significativo en el nivel de fluorescencia $(\Delta R n)$ y en el que se inicia la detección, asociado con un crecimiento exponencial del producto de PCR durante la fase logarítmica. Esta fase proporciona la información más útil sobre la reacción. El parámetro más importante para la cuantificación es el $\mathrm{C}_{\mathrm{T}}$. Cuanto mayor sea la cantidad inicial de ADN, antes se detectará el producto acumulado en la PCR, y más bajo será el valor $\mathrm{C}_{\mathrm{T}}$.

La pendiente de una fase logarítmica es un reflejo de la eficiencia de la amplificación. Este umbral puede calcularse como la desviación estandar de $\mathrm{Rn}$ durante estos primeros ciclos multiplicada por un factor de ajuste. La eficiencia de la PCR suele ser del 90-100\% $(-3,6>$ pendiente $>-3,1)$, esta puede verse afectada por numerosas variables.

\subsubsection{5 - Cuantificación}

Existen dos maneras de cuantificar una muestra problema de ADN mediante Real-time PCR: la cuantificación absoluta y la cuantificación relativa.

En la cuantificación absoluta la concentración de ADN de las muestras que se desea amplificar se estima interpolando sus valores de $\mathrm{C}_{\mathrm{T}}$ en una recta patrón construida con estándares de concentración conocida. Este método requiere de la cuantificación previa del stock de ARN, utilizado para la construcción de la recta patrón, mediante otros métodos, como la espectrometría.

La cuantificación relativa consiste en comparar la amplificación de una secuencia de ADN problema respecto a otra, denominada "control endógeno". La cuantificación relativa se lleva a cabo utilizando el método de la recta patrón o el método comparativo de los $\mathrm{C}_{\mathrm{T}}(\Delta \Delta \mathrm{CT})$.

Este método es el que hemos utilizado en este trabajo. Se utilizan una serie de 
fórmulas aritméticas (Pfaffl, 2001) para conseguir el mismo resultado de cuantificación relativa. Para utilizar este método (como sustitutivo del de las rectas patrón) es necesario que la eficiencia de la amplificación del gen problema y la del gen endógeno sean semejantes estadísticamente.

La principal ventaja de este método en nuestro caso es, que dado el elevado número de muestras a analizar, el método de las rectas patrón supone una mayor complejidad a la hora de diseñar los ensayos de PCR.

Para cada par de oligonucleótidos se comprobó la eficiencia de las reacciones de RT-PCR mediante el uso de distintas diluciones de ADNc.

Para cada muestra las reacciones fueron llevadas a cabo por triplicado. Para el cálculo del $\Delta \Delta \mathrm{CT}$ se necesita la media de los valores CT y las desviaciones estándar correspondientes.

Los cálculos son realizados automáticamente por el programa controlador del termociclador "ABI PRISM 7700 Sequece Detector System".

En todo el proceso, se siguieron las recomendaciones de Applied Biosystems y de acuerdo con sus instrucciones de los manuales "Guide to Performing Relative Quantification of Gene Expression Using RealTime Quatitative PCR" y "Relative Quantitation of Gene Expression: $A B I$ PRISM7700 Sequence Detection System".

\subsection{1 - Hibridación de ácidos nucleicos}

\subsection{1 - Marcaje de sondas}

Se utilizó el procedimiento no radiactivo basado en la incorporación de dUTP marcado con digoxigenina (DIG) en la síntesis de la sonda, la detección de la DIG mediante anticuerpos específicos conjugados con fosfatasa alcalina (antiDIG-fosfatasa alcalina), y la generación de bioluminiscencia por esta enzima a partir de un sustrato apropiado. Para ello se siguieron las técnicas recomendadas en el manual "The DIG System User's Guide for Filter Hybridization" (Roche), así como las del manual "Hybond-N; nylon membrane" (Amersham) para la transferencia de ácidos nucleicos a filtros.
Se llevó a cabo una reacción normal de PCR en la que se sustituyeron los dNTPs por la mezcla de marcado "Polymerase chain reaction (PCR) digoxigenin labeling mix" (Roche), usando como ADN molde un plásmido $\circ$ un fragmento de ADN que contuviese la zona que se deseaba marcar: el producto obtenido es de mayor peso molecular que el mismo fragmento sin marcar, por lo que el resultado pudo comprobarse mediante electroforesis en gel de agarosa; si la sonda necesitaba una mayor densidad de marcado, se utilizó el "PCR DIG probe synthesis kit" (Roche). Como se verá a continuación ambos tipos de marcaje pueden retirarse mediante lavados. Las sondas 
fueron almacenadas a $-20{ }^{\circ} \mathrm{C}$ hasta su utilización.

\subsection{2 - Hibridación tipo Southern}

La técnica utilizada fue desarrollada por Southern en 1975. Se ha seguido el protocolo descrito por Sambrook (Sambrook et al., 1989), con algunas modificaciones.

El ADN digerido con la enzima de restricción se hizo correr en un gel de agarosa.

Tras la electroforesis, los geles de agarosa se iluminaron con luz UV (260nm de longitud de onda) durante 2-3 minutos, con el fin de crear roturas en las moléculas de ADN y favorecer así la transferencia de fragmentos de ADN relativamente grandes (mayores de $10 \mathrm{~kb})$.

\subsubsection{1 - Transferencia}

Los geles se sumergieron en solución de desnaturalización $(\mathrm{NaOH}$ 0,5 M, NaCl 1,5 M) durante $1 \mathrm{~h}$ en agitación a temperatura ambiente y posteriormente en solución de neutralización (Tris-HCl $1 \mathrm{M} \mathrm{pH} 7,5 \mathrm{NaCl}$ 1,5 M) en las mismas condiciones. Tras estos tratamientos se procedió a transferir el ADN.

La unidad de transferencia consistió en una bandeja que contenía el tampón de transferencia SSC 10X ( $\mathrm{NaCl} 1,5 \mathrm{M}$; citrato sódico $0,15 \mathrm{M} \mathrm{pH} \mathrm{7,0),} \mathrm{sobre} \mathrm{la} \mathrm{que} \mathrm{se} \mathrm{sujetó}$ una placa de plástico. Sobre ésta se colocaron dos tiras de papel Whatman 3MM cuyos extremos se sumergían en el tampón de transferencia.
El gel se colocó sobre el papel Whatman 3MM y sobre él se dispuso una pieza de nailon Hybond- $N$ y dos piezas de papel Whatman (previamente humedecidas en SSC 2X), todas de las mismas dimensiones que el gel, eliminando las burbujas de aire entre las distintas capas. El gel se rodeó con láminas de plástico y sobre el conjunto gel-membrana se colocó una resma de papel absorbente y un peso de aproximadamente $500 \mathrm{~g}$. Transcurridas 12-16 h se procedió a la fijación irreversible del ADN a la membrana mediante calentamiento a 80 ${ }^{\circ} \mathrm{C}$ durante 2 horas $\mathrm{O}$ bien mediante la irradiación con luz UV en un Stratalinker. Estas membranas se guardaron a temperatura ambiente hasta su utilización. La eficiencia de la transferencia se comprobó tiñendo el gel con una solución de bromuro de etidio en exceso $(0,5 \mathrm{mg} / \mathrm{ml})$ en TAE $1 \mathrm{X}$ y observando que el ADN había desaparecido del gel.

\subsubsection{2 - Prehibridación e hibridación}

Los pasos seguidos en todos los casos fueron prehibridación, hibridación, lavado de filtros, detección y eliminación de sonda. La prehibridación y posterior hibridación de las membranas a las cuales se transfirieron los ácidos nucleicos se llevaron a cabo en bolsas de plástico, cajas de plástico o en tubos de vidrio perfectamente cerrados, con agitación moderada y constante, utilizando volúmenes de hibridación mínimos pero suficientes para mantener las membranas siempre húmedas. La 
temperatura de prehibridación y de hibridación de $A D N$ fue de $65^{\circ} \mathrm{C}$ para hibridaciones restrictivas, mientras que para las no restrictivas fue inferior y dependió de cada caso.

Se utilizó un tampón de prehibridación e hibridación cuya composición es SSC 5X, $\mathrm{n}$-laurilsarcosina $0,1 \% \mathrm{p} / \mathrm{v}$, SDS 0,02 \% (p/v) y reactivo bloqueante $1 \% \mathrm{w} / \mathrm{v}$ (Blocking Reagent, Roche). La prehibridación se mantuvo durante al menos $1 \mathrm{~h}, \mathrm{y}$ seguidamente se añadió la sonda previamente desnaturalizada (10 minutos a $\left.100{ }^{\circ} \mathrm{C}\right)$; la solución de prehibridación fue retirada si se trataba de la primera utilización del filtro o si la sonda estaba ya diluída en la solución de hibridación, pero se mantuvo en el resto de los casos; tras una noche de incubación en las condiciones adecuadas se procedió a retirar la solución de hibridación (que se guardó a $-20{ }^{\circ} \mathrm{C}$ para su posterior utilización).

\subsubsection{3 - Lavado de filtros}

El lavado de la membrana para eliminar los restos de sonda consistió en 2 incubaciones de 5 minutos a temperatura ambiente con solución de lavado 2X (SSC 2X, SDS $0,1 \%(\mathrm{p} / \mathrm{v}))$ y 2 incubaciones de 15 minutos a la temperatura de hibridación con solución de lavado $0,1 X$ (SSC 0,1X, SDS 0,1 $\%(p / v))$.

\subsubsection{4 - Detección}

La detección se llevó a cabo siguiendo las instrucciones del fabricante, como se describe a continuación. Las soluciones empleadas en la detección se diluyeron en tampón 1 (ácido maleico 100 $\mathrm{mM}, \mathrm{NaCl} 150 \mathrm{mM}$ pH 7,5). Las membranas se equilibraron en tampón de lavado (tampón 1 con Tween $20 \quad 0,3 \%(\mathrm{v} / \mathrm{v}))$ durante 5 minutos y posteriormente se bloquearon en tampón 2 (reactivo bloqueante $1 \%$ (p/v) disuelto en tampón 1) durante 30 minutos. Pasado este tiempo las membranas se incubaron en la solución que contiene el anticuerpo anti-digoxigenina conjugados con la enzima fosfatasa alcalina (Anti Digoxigenin AP, Roche), dilución 1:20.000 en tampón 2, durante 30 minutos y se lavaron 2 veces con tampón de lavado durante 15 minutos para eliminar el anticuerpo que no se hubiera unido a la sonda.

Las membranas se equilibraron en tampón 3 (Tris- $\mathrm{HCl} 100$ mM, NaCl 10 mM pH 9,5) durante 5 minutos, se dispusieron sobre plástico y sobre ellas se añadió el sustrato quimioluminiscente CDP-Star (Roche), que es un sustrato muy sensible para la fosfatasa alcalina y en dicha reacción genera rápidamente una señal luminosa. Dicho sustrato se diluyó en tampón 3 hasta 0,25 $\mathrm{mM}$; las membranas se taparon con otra capa de plástico y se incubaron durante 5 minutos a temperatura ambiente. Seguidamente se retiró el exceso de líquido de las membranas, se envolvieron en plástico y se visualizaron utilizando el "Intelligent Dark Box II" (Fujifilm). 
3.11.2.5 - Eliminación de la sonda

Para retirar la sonda de las membranas éstas fueron lavadas a temperatura ambiente en agua destilada estéril durante 1 a 5 minutos y tratadas dos veces con una solución de $\mathrm{NaOH}$ 0,2 $\mathrm{M}$ y SDS $0,1 \%(p / v)$ durante 20 minutos; seguidamente fueron lavadas en una solución de SSC 2X durante 5 minutos y reutilizadas o guardadas en esta solución a $4^{\circ} \mathrm{C}$.

\subsection{2 - Hibridación substractiva}

La hibridación substractiva (SSH) es una técnica que permite comparar dos poblaciones de ARN mensajero obteniendo como resultado una colección de clones que contienen genes expresados en una de las poblaciones pero no en la otra.

La técnica se resume en los siguientes pasos: las dos colecciones de ARNm a comparar se convierten a ADNc, las dos muestras de ADNc se hibridan entre si y las secuencias hibridadas se eliminan quedando solo ADNc no hibridado que se corresponde con los genes presentes en una pero ausentes en otra de las colecciones.

Existen kits comerciales que simplifican las técnicas tradicionales, al no requerir varias rondas de hibridaciones y son sensibles con los transcritos raros. En nuestro trabajo hemos optado por el kit "PCR-Select cDNA Subtraction" de Clontech Laboratories. El primer paso es la sintetización de cDNA a partir de ARNm poliA, este último producido con el kit "Oligotex mRNA" de QIAGEN. Una de las poblaciones se divide en dos mitades iguales, cada una de las cuales se hibrida con un adaptador diferente.

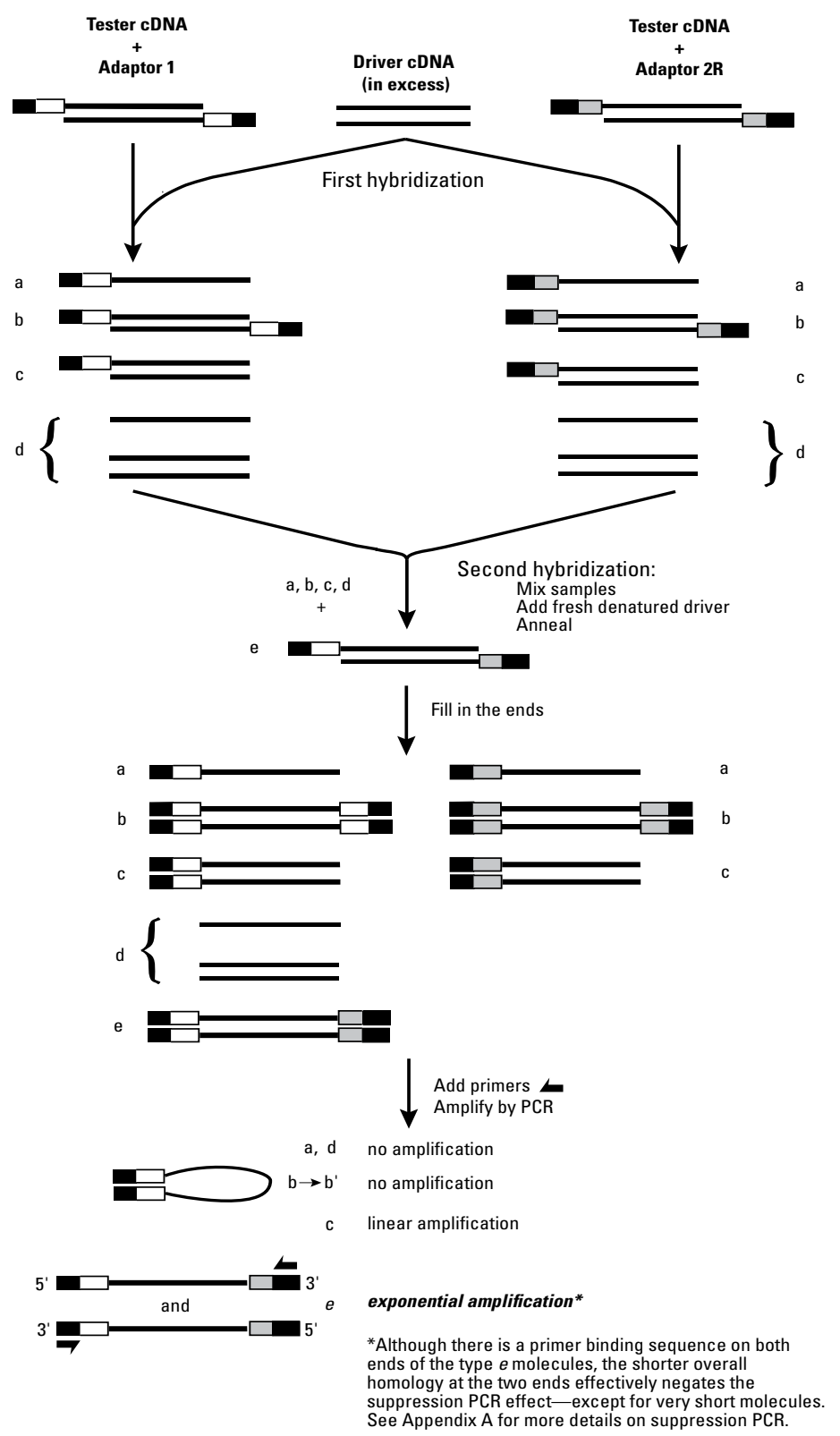

Figura 3. 3 - Posibles productos de la primera y la segunda hibridización del protocolo de hibridación substractiva (Clontech). 
En la primera ligación cada una de las subpoblaciones con adaptor diferente se hibrida con una parte de la otra población inicial. Como resultado se obtendrán cadenas no hibridadas (a) con y (d) sin adaptador, y cadenas hibridadas (b) las dos con adaptador, (d) las dos sin adaptador y (c) mezcla.

En este paso la concentración de los transcritos numerosos y raros tiende a equilibrarse pues los más comunes hibridan con mayor frecuencia.

En la segunda hibridación juntamos todos los productos de la primera hibridación de ambos subpoblaciones. Solo las cadenas diferenciales, que no habían hibridado en el paso anterior, podrán hibridar entre si, portando cada una de ellas un adaptador diferente.

Los siguientes pasos consisten en la amplificación de las secuencias de doble cadena diferenciales. Los fragmentos con dos adaptadores del primer tipo forman un bucle que impide su amplificación exponencial. Solo las cadenas portando adaptadores diferentes se unen a los dos cebadores (oligonucleótidos) de PCR diferentes, y se amplifican exponencialmente. Este proceso se divide en dos PCR diferentes de ciclos cortos para disminuir el error de fondo.

Los productos de PCR se pueden ligar con normalidad a los vectores de clonación (como pGEN-Easy).

\subsection{3 - Programas informáticos y bases de datos}

\subsection{1 - Diseño de oligonucleótidos}

Para el diseño de oligonucleótidos se usaron los programas Genious (Biomatters) y VectorNTI Suite 10 (Invitrogen).

El programa Primer Express 1.0 (Applied Biosystems) se utilizó para el diseño de oligonucleótidos y sondas TaqMan para PCR cuantitativa.

Para las sondas TaqMan MGB y las parejas de oligonucleótidos correspondientes se acudió al servicio "Assays-by-Design Service" de Applied Biosystems. Este servicio diseñó, sintetizó y controló la calidad de las parejas de oligonucleótidos y las sondas correspondientes para ensayos de expresión génica, basándose en las secuencias de nucleótidos que les fueron enviadas y que contenían las regiones de nuestro interés.

\subsection{2 - Edición de plásmidos}

Se utilizó el programa VectorNTI Suite 10 (Invitrogen).

\subsection{3 - Edición de cromatogramas}

Para la visualización del cromatograma generado en la secuenciación se utilizó el programa Geneious (Biomatters) y FinchTV (Biospiza). 
3.13.4 - Edición, alineamiento y relaciones

filogenéticas de secuencias

El trabajo bioinformático se basó directamente en el programa Genious (Biomatters), bien directamente, bien como interfaz gráfica (frontend) de otros programas como ClustalW 2 (Larkin et al., 2007), MUSCLE (Edgar, 2004) y phyML (Guindon \& Gascuel, 2003).

En algunos casos también se usó la herramienta online LIRMM (www.phylogeny.fr) (Universidad de Marsella) para la construcción automátizada de filogenias.

\subsection{5 - Bases de datos}

Se consultaron las bases de datos del Sanger Institute de genomas secuenciados (http://www.genedb.org) y del Broad Institute (http://www.broad.mit.edu).

La búsqueda de secuencias homólogas se llevó a cabo usando distintos programas disponibles en el sitio http://www.expasy.ch.

Para la comparación de dominios y regiones promotoras se usaron las bases de datos PFAM (http://pfam.sanger.ac.uk/) y UNIPROT (uniprot.org).

\subsection{6 - Visualización de imágenes}

Para la visualización de imágenes de quimioluminiscencia se utilizó el programa LAS-1000 Plus (Fujifilm), para la cuantificación de ARN.
Para la visualización de luz ultravioleta el programa Gel Logic 100 Imaging System (Kodak).

\subsection{7 - Análisis estadística}

Para el análisis estadístico se usaron los programas ABI PRISM v1.2.3 (Applied Biosystems) y Excel (Microsoft).

\subsection{8 - Bibliografía y edición de textos}

Para la edición de la bibliografía se utilizó el programa Endnote X2 (Thompson Reuters) y como procesador de textos Word 2008 (Microsoft). 


\begin{tabular}{|c|c|c|}
\hline Oligonucleótido & Sentido & Secuencia $5^{\prime}-3^{\prime}$ \\
\hline CNS1 & + & GAGACAAGCATATGACTACTG \\
\hline CNL12 & - & CTGAACGCCTCTAAGTCAG \\
\hline FoMAT2p10 & + & GAATAGGGAAATGCAAAAATCTGA \\
\hline FMATp2 & - & AACCCTGTGTCCTTTAACCCTGAGCAT \\
\hline FMATp1 & + & GACCTAGTGCAACAAGAAACAAAAGCGAGTG \\
\hline FoMAT2p2 & - & GTCACCAGTCGATCAAGGCTCAAC \\
\hline FoMAT1-2p1 & + & GTTTTGACCGCATTGATTGGACTACC \\
\hline FoMAT1-2p2 & - & CTACACAACACCCACACTTCTCATCAT \\
\hline B310 & + & CAGCCATTCATGGATGACATAACGAATTTC \\
\hline A280 & + & TATACCGGACGGGCGTAGTGACGATG \\
\hline B5 & + & CGTTTCCCTACTAGATCACACCCA \\
\hline M17A & - & GTTTGACCACGGGGCGAGTTAC \\
\hline M18B & + & CGCCAAAACGCAAGCTCAACTTC \\
\hline M19A & - & GCGAGGGGTGCCGAAACAAAGC \\
\hline S62 & + & CCATGGATTGTGGGAAGAAGAACCTCACTA \\
\hline A64 & - & GCGGCCGCGGCTTGTTGGCTTCATGGATGGAT \\
\hline A65 & - & GCGGCCGCAAGGAAGGATAGCTGTGTGGCTCG \\
\hline hphA & + & CACAGCCATCGGTCCAGACG \\
\hline hphB & - & GCCTGAAACCGAACTGCCCG \\
\hline hphAc & - & CGGGCAGTTCGGTTTCAGGC \\
\hline hphBc & + & CGTCTGGACCGATGGCTGTG \\
\hline BTub4_FWD & + & CAGTCCGGTGCTGGAAACA \\
\hline BTub4_REV & - & AAGTTCGGCACCCTCAGTGT \\
\hline homoFTF_FWD & + & GGACATTCATCGCTGCGAA \\
\hline homoFTF_REV & - & AGGAAAAGGCGCAGTATCCAG \\
\hline ftf2_espe3_FWD & + & ATGCTCACACСCССАСАТTCT \\
\hline ftf2_espe3_REV & - & ATCCCCCAAAGACAAGCTGAC \\
\hline ftf1_espe4_FWD & + & TGTGGTGGCCAGGATATGATG \\
\hline ftf1_espe4_REV & - & TGCATGCCTGCCTTGACAT \\
\hline 03747_FWD & + & TGCATGGAAAGCGCATCAT \\
\hline 03747_REV & - & GCATACCACTAGGATGCGGAA \\
\hline 04611_FWD & + & TGGCATCACAAGAAGCTCCAG \\
\hline 04611_REV & - & CCAGTTTGCGAACAGAATCCA \\
\hline 08338_FWD & + & CAAACCGTTGCTCCCACTGTA \\
\hline 08338_REV & - & ATTTCCATTGGCGACACCG \\
\hline Aspar-prote_FWD & + & GCTCACTTCCATGGCTGATCA \\
\hline Aspar-prote_REV & - & GCGATCAATACCGCCGTAGAT \\
\hline GAT1_FWD & + & TGAGAACATTTGCAGCGATGC \\
\hline GAT1_REV & - & CCGAGATCGAATCGAAGGTTG \\
\hline Pal1_FWD & + & AAGGAGCAAAAGCGTTTCCG \\
\hline Pal1_REV & - & AAGCTGCGGTTGTGGCTAAAG \\
\hline SIP5_FWD & + & ATCCCTTTGTGAACGGCCA \\
\hline SIP5_REV & - & GCATCTGGTGCGGTTCAAGTA \\
\hline Sec17_FWD & + & AAGGCCTACCGCAAAGACGAT \\
\hline Sec17_REV & - & CGTACAGCTCGCCGAGATTTT \\
\hline TAUD_FWD & + & CTTTGGTGTCATTCGTGGCCT \\
\hline TAUD_REV & - & GCCCATGACGATTGGCAAT \\
\hline TFIID_FWD & + & GAAGACGATTCGAAGCTCGCT \\
\hline TFIID_REV & - & GCAAGAGCCGACAATGTTCTG \\
\hline Tiamina2_FWD & + & TCGGAAACGGTGACTTTGATG \\
\hline Tiamina2_REV & - & ATCGATCTGCTCGGCAATCTC \\
\hline Hypox_FWD & + & ATTGTCTTCGCGTCGTGGTT \\
\hline Hypox_REV & - & CGCATAAACACGAGCTTGCA \\
\hline
\end{tabular}

Tabla 3. 1 - Oligonucleótidos usados en este trabajo. Los oligonucleótidos con el mismo color de fondo se complementan para la obtención de un amplicón. 


\begin{tabular}{|c|c|c|c|c|c|c|c|}
\hline Aislado & Codigo & Virulencia & VCG & RFLP-IGS & MAT & Raza & Origen \\
\hline ATCC 18131 & SC & HV & 161 & B5 & MAT1-1 & 1 & Carolina del Sur (Howard F. Schwarzt) \\
\hline ATCC 42145 & BR24 & HV & 161 & B2 & & 2 & Río de Janeiro (Howard F. Schwarzt) \\
\hline ATCC 90245 & $\mathrm{CO}$ & HV & & B4 & MAT1-1 & 4 & Colorado (Howard F. Schwarzt) \\
\hline Fo $10 \mathrm{COL}$ & CL10 & & 164 & & MAT1-1? & 3 & Colombia (George Mahuku - CIAT) \\
\hline Fo 10Ph & GR10 & HV & 165 & & MAT1-1? & 5 & Kastoria (Kalomira Elena) \\
\hline Fo 27Ph & GR27 & HV & & & MAT1-1? & 7 & Chryssoupolis (Kalomira Elena) \\
\hline FO $28 \mathrm{COL}$ & CL28 & HV & 163 & & MAT1-2? & 3 & Colombia (George Mahuku - CIAT) \\
\hline Fo 3Ph & GR3 & $\mathrm{HV}$ & & C & & 7 & Chryssoupolis (Kalomira Elena) \\
\hline Fo $45 \mathrm{COL}$ & CL45 & HV & 164 & & MAT1-2? & 3 & Colombia (George Mahuku - CIAT) \\
\hline Fo 5 BRA & BR5 & & 162 & A & MAT1-1 & 2 & Pernambuco (George Mahuku - CIAT) \\
\hline FOP-CL25 & CL25 & HV & 164 & B4 & MAT1-1 & 3 & Colombia (Howard F. Schwarzt) \\
\hline FOP-SP01 & AB06 & HV & 167 & A & MAT1-2 & 6 & La Carrera (CIALE) \\
\hline FOP-SP02 & $\mathrm{AB} 111$ & HV & 167 & A & MAT1-2 & 6 & El Barco de Ávila (CIALE) \\
\hline FOP-SP03 & $\mathrm{AB} 112$ & HV & 168 & A & MAT1-2 & 6 & El Barco de Ávila (CIALE) \\
\hline FOP-SP04 & AB35 & WV & 166 & A & MAT1-2 & 6 & La Carrera (CIALE) \\
\hline FOP-SP05 & AB44 & WV & 166 & A & MAT1-2 & 6 & La Carrera (CIALE) \\
\hline FOP-SP06 & AB46 & WV & 166 & A & MAT1-2 & 6 & La Carrera (CIALE) \\
\hline FOP-SP07 & AB87 & WV & 166 & A & MAT1-2 & 6 & La Carrera (CIALE) \\
\hline FOP-SP08 & AB98 & WV & 166 & A & & 6 & El Barco de Ávila (CIALE) \\
\hline FOP-SP09 & AN3 & WV & 166 & A & & 6 & Navalonguilla (CIALE) \\
\hline FOP-SP11 & & & & & MAT1-2 & & El Barco de Ávila (CIALE) \\
\hline FOP-SP12 & & & & & MAT1-2 & & El Barco de Ávila (CIALE) \\
\hline FOP-SP13 & AV1 & SV & 169 & A & MAT1-2 & & Villafranca (CIALE) \\
\hline FOP-SP14 & AV2 & SV & 169 & A & MAT1-2 & & Villafranca (CIALE) \\
\hline FOP-SP15 & AV3 & SV & 169 & A & MAT1-2 & & Villafranca (CIALE) \\
\hline FOP-SP16 & AV4 & SV & 169 & A & MAT1-2 & & Villafranca (CIALE) \\
\hline FOP-SP17 & AV5 & SV & 169 & A & MAT1-2 & & Villafranca (CIALE) \\
\hline FOP-SP18 & AV6 & SV & 169 & A & MAT1-2 & & Villafranca (CIALE) \\
\hline FOP-SP19 & AV7 & SV & 169 & A & MAT1-2 & & Villafranca (CIALE) \\
\hline FOP-SP20 & AV8 & SV & 169 & A & MAT1-2 & & Villafranca (CIALE) \\
\hline FOP-SP21 & AV9 & SV & 169 & A & MAT1-2 & & Villafranca (CIALE) \\
\hline FOP-SP22 & AV10 & HV & 169 & A & MAT1-2 & & Villafranca (CIALE) \\
\hline FOP-SP23 & AV11 & HV & 169 & A & MAT1-2 & & Villafranca (CIALE) \\
\hline FOP-SP24 & AV12 & HV & 169 & A & MAT1-2 & & Villafranca (CIALE) \\
\hline FOP-SP25 & AV13 & HV & 169 & A & MAT1-2 & & Villafranca (CIALE) \\
\hline FOP-SP26 & AV14 & HV & 169 & A & MAT1-2 & & Villafranca (CIALE) \\
\hline FOP-SP27 & AV15 & HV & 169 & A & MAT1-2 & & Villafranca (CIALE) \\
\hline FOP-SP28 & AV16 & HV & 169 & A & MAT1-2 & & Villafranca (CIALE) \\
\hline FOP-SP29 & AV19 & $\mathrm{HV}$ & 169 & A & MAT1-2 & & Villafranca (CIALE) \\
\hline FOP-SP30 & AV17 & WV & 169 & A & MAT1-2 & & Villafranca (CIALE) \\
\hline FOP-SP31 & AV20 & WV & 169 & A & MAT1-2 & & Villafranca (CIALE) \\
\hline FOP-SP32 & AV28 & WV & 169 & A & MAT1-2 & & Villafranca (CIALE) \\
\hline FOP-SP33 & AV24 & $\mathrm{HV}$ & 169 & B2 & MAT1-2 & & Villafranca (CIALE) \\
\hline FOP-SP34 & AV21 & WV & 1610 & A & MAT1-2 & & Villafranca (CIALE) \\
\hline FOP-SP35 & AV27 & WV & 1610 & B2 & MAT1-2 & & Villafranca (CIALE) \\
\hline FOP-SP36 & AV22 & WV & 1611 & B2 & MAT1-2 & & Villafranca (CIALE) \\
\hline \multirow[t]{2}{*}{ FOP-SP37 } & AV23 & WV & 1612 & B2 & MAT1-2 & & Villafranca (CIALE) \\
\hline & AB82 & NP & 167 & A & & & El Barco de Ávila (CIALE) \\
\hline
\end{tabular}

Tabla 3. 2 - Estirpes de F. oxysporum f.sp. phaseoli utilizadas. SV: Supervirulento HV: Altamente virulento. WV: Débilmente virulento. NP: No patógeno 


\begin{tabular}{|c|c|c|c|c|c|}
\hline Forma especial & Codigo & Hospedador & VCG & Origen & Colección \\
\hline apii & 183.38 & Apium graveolens & & & CBS \\
\hline betae & 175.32 & Beta splendens & & & CBS \\
\hline betae & 36283 & Beta splendens & & & NRRL, K. \\
\hline conglutinans & 186.53 & Brassica oleracea & & Florida o Carolina del Sur (EE.UU.) & CBS \\
\hline cubense & 102023 & Musa sapientum cv. Cavendish & & Burgershall/Hazyview (Sudáfrica) & CBS \\
\hline dianthi & 417.90 & Dianthus barbatus & & Bet Dagan (Israel) & CBS \\
\hline gladioli & 640.91 & Gladiolus cv. alba & 341 & Lisse (Holanda) & CBS \\
\hline lupini & 279.85 & Lupinus & 2 & Carolina del Sur (EE.UU.) & CBS \\
\hline lycopersici & 26034 & Lycopersicon sculentum & & & NRRL, K. \\
\hline lycopersici & 26383 & Lycopersicon sculentum & & & NRRL, K. \\
\hline lycopersici & 2715 & Lycopersicon sculentum & & Carolina del Sur (EE.UU.) & CECC \\
\hline lycopersici & $42-87$ & Lycopersicon sculentum & 2 & & INIA , J. Tello \\
\hline lycopersici & 281 & Lycopersicon sculentum & 2 & & INIA, J. Tello \\
\hline melonis & 422.90 & Cucumis melo cv galia & 0 & Bet Dagan (Israel) & CBS \\
\hline nicotianae & T1 & Nicotiana tabacum & & Extremadura & F. Alves-Santos \\
\hline nicotianae & T2 & Nicotiana tabacum & & Extremadura & F. Alves-Santos \\
\hline nicotianae & T3 & Nicotiana tabacum & & Extremadura & F. Alves-Santos \\
\hline nicotianae & T4 & Nicotiana tabacum & & Extremadura & F. Alves-Santos \\
\hline nicotianae & T5 & Nicotiana tabacum & & Extremadura & F. Alves-Santos \\
\hline nicotianae & $\mathrm{F} 1$ & Nicotiana tabacum & & Extremadura & F. Alves-Santos \\
\hline nicotianae & N1 & Nicotiana tabacum & & Extremadura & F. Alves-Santos \\
\hline pini & Fo1 & Pinus nigra & & Perica y Gómez (Valladolid) & F. Alves-Santos \\
\hline pini & Fo2 & Pinus pinea & & Perica y Gómez (Valladolid) & F. Alves-Santos \\
\hline pini & Fo4p & Quercus & & Indesfor (Soria) & F. Alves-Santos \\
\hline pini & Fo5p & Pinus & & Imave (León) & F. Alves-Santos \\
\hline pini & Fo6p & Pinus & & Perica (Valladolid) & F. Alves-Santos \\
\hline pini & 171.31 & Pinus & & Görsdorf (Alemania) & CBS \\
\hline pisi & 260.50 & Pisum sativum & 1 & EE.UU. & CBS \\
\hline pisi & 29869 & Pisum sativum & & & NRRL, K. \\
\hline radicis- & 872.95 & Lycopersicon sculentum & & Israel & CBS \\
\hline raphani & 262.50 & Raphanus & & & CBS \\
\hline vasinfectum & 409.90 & Gossypium barbadense cv pima & & Bet Dagan (Israel) & \\
\hline graminearum & Fg1 & Zea mays & & Salamanca & CIALE \\
\hline
\end{tabular}

Tabla 3. 3 - Estirpes de Fusarium oxysporum pertenecientes a la forma especial indicada en la primera columna usadas en este estudio. 


\section{Resultados}





\section{1 - Caracterización de aislados de Fusarium oxysporum \\ obtenidos en plantas de judión (Phaseolus coccineous)}

\subsection{1 - Estudio de la patogenicidad y virulencia}

En estudios previos de nuestro grupo de investigación, se recogieron plantas de judión en la zona de El Barco de Ávila (Ávila España) con la sintomatología de la fusariosis vascular. Solo se consideró un aislado por muestra de planta y se obtuvieron líneas monoespóricas para añadir a la colección.

Las plantas de judión ( $P$. coccineous L.) de mayor porte y grosor que las de la judía común (Phaseolus vulgaris L.) son potencialmente un hospedador más adecuado para buscar aislados con una virulencia distinta a las previamente estudiadas.

\subsubsection{1 - Ensayos de patogenicidad en judión ( $P$. coccineous)}

Se estudiaron 25 líneas independientes en un ensayo de patogenicidad en judión ( $P$. coccineous), el hospedador en las que fueron aislados.

En la Figura 4. 1 (Pág. 71), se evalua la progresión de la infección en los aislados que resultaron denominados supervirulentos. Se observa que el proceso de infección dura

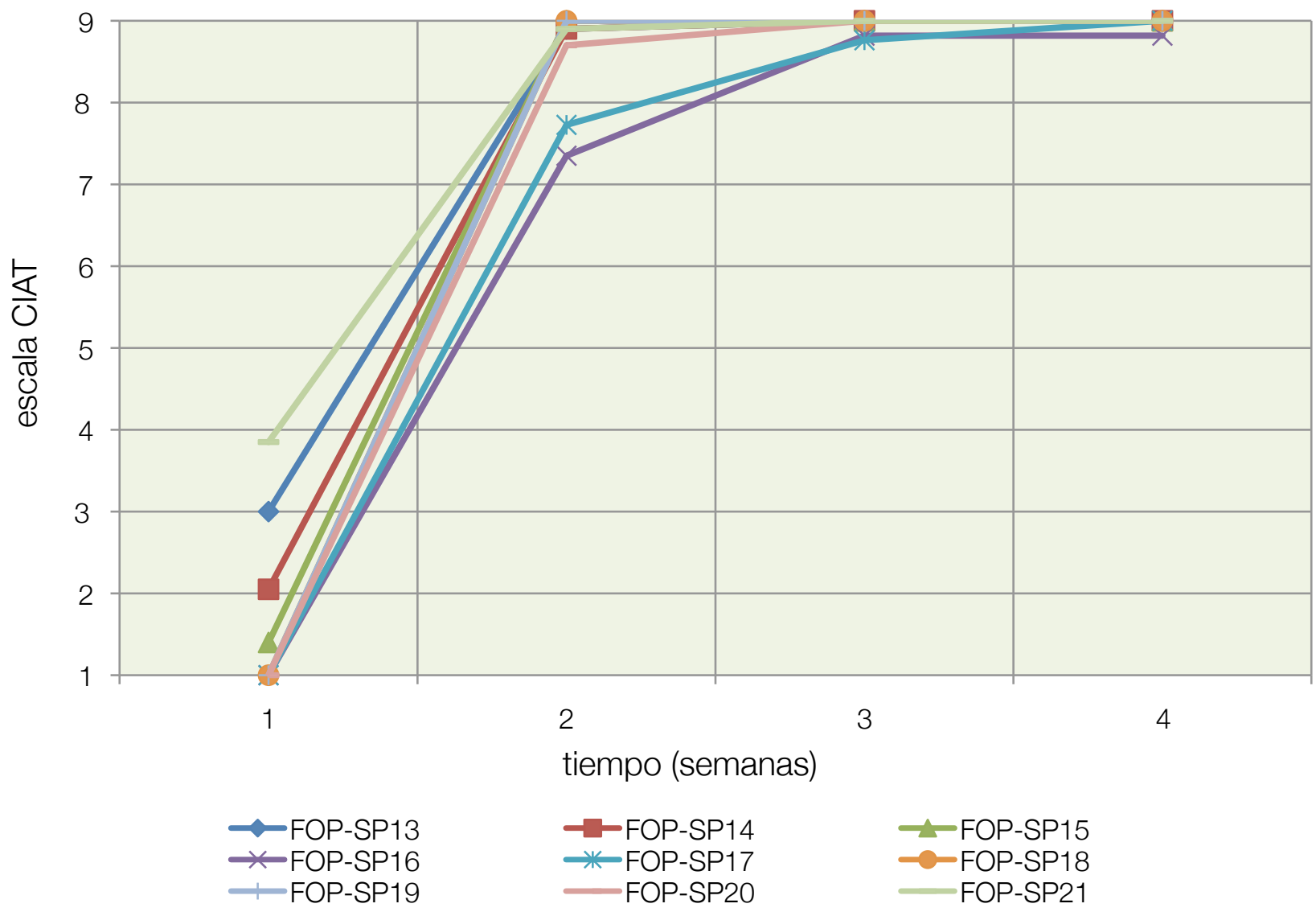

Figura 4. 1 - Virulencia de los aislados supervirulentos según su valor en la escala CIAT en plantas de judión ( $P$. coccineous) durante las cuatro primeras semanas de la infección. 
solo dos semanas, tras las cuales la mayor parte, si no todas las plantas, han muerto por la infección (Figura 4. 2). Para alcanzar el mismo estado de infección en los aislados más virulentos previamente conocidos (altamente virulentos en judía) se requerían cuatro semanas. Muertas las plantas hay poca variación intraespecífica en la tercera y cuarta semana. El grupo lo conforman los aislados que alcanzan un valor en la escala CIAT superior a 7 en dos semanas.

El grupo con una respuesta altamente virulenta en judión (Figura 4. 3 - Pág. 72) es inicialmente más diverso, y con el tiempo, ve reducida su variación interna en la cuarta semana, momento en el que los aislados

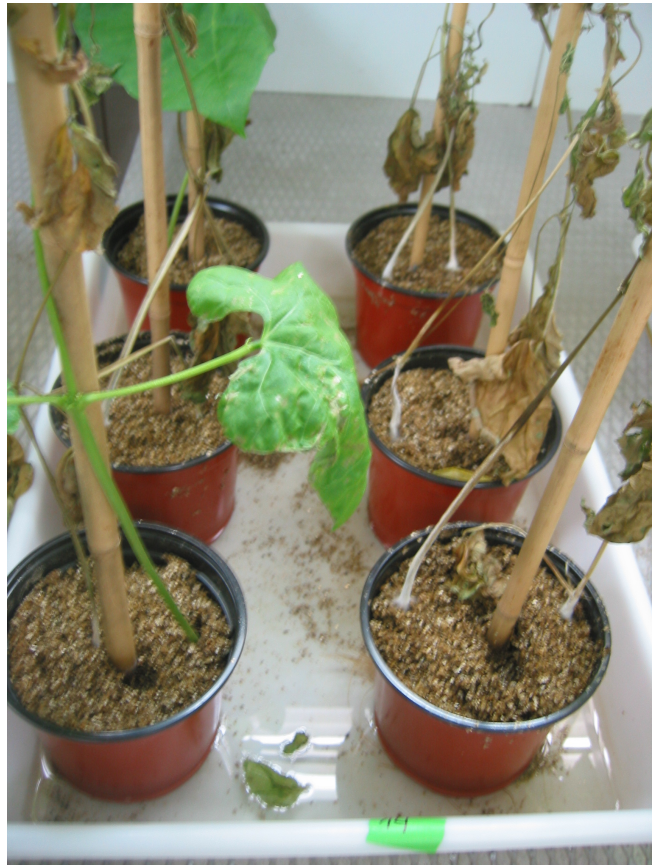

Figura 4. 2 - Detalle del desarrollo de la sintomatología tras dos semanas tras la infección en plantas infectadas con FOPSP14.

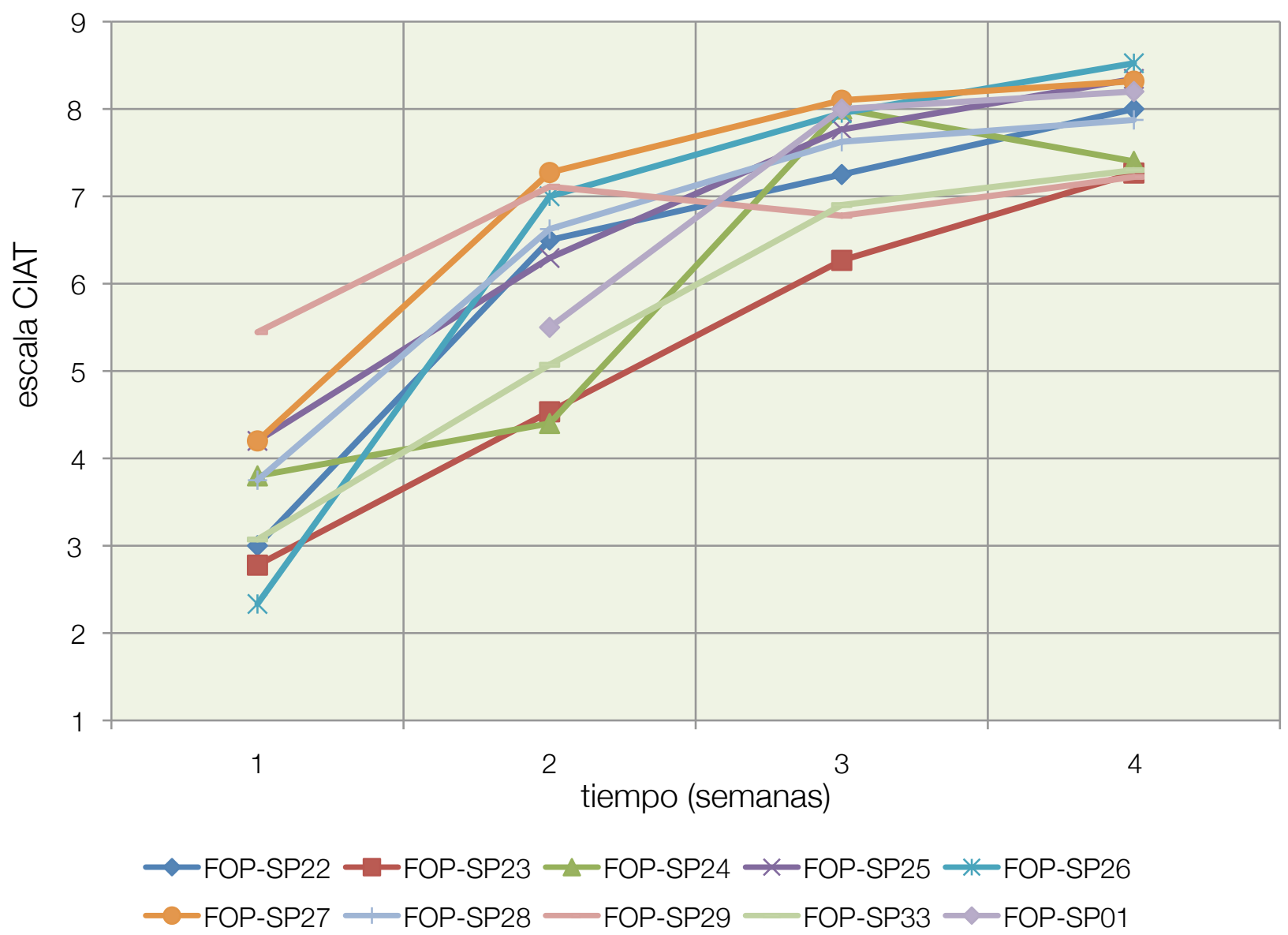

Figura 4. 3 - Virulencia de los aislados altamente virulentos según su valor en la escala CIAT en plantas de judión ( $P$. coccineous) durante las cuatro primeras semanas de la infección. 
alcanzan un valor en la escala CIAT superior a 7. El resultado final es similar, pero el tiempo necesario el doble (cuatro semanas) que en el caso de los supervirulentos. Se caracterizan de forma análoga a los altamente virulentos obtenidos en judía, como aquellos en los que se alcanza un valor en la escala CIAT mayor a 7 tras 4 semanas (Alves-Santos et al., 1999).

El tercer grupo engloba los aislados débilmente virulentos en judión (Figura 4. 4 Pág. 73), el fenotipo observado es similar al grupo de débilmente virulentos en judía. Se caracterizan porque al cabo de 4 semanas no superan un valor de 7 en la escala CIAT (Alves-Santos et al.,1999). La mayoría de los aislados siquiera alcanzan un valor de 6 en la escala CIAT. Es un grupo con una mayor diversidad interna pues tenemos plantas muertas o prácticamente muertas y con la enfermedad desarrollo, estas últimas con una sintomatología clara, con la mitad inferior de las hojas necróticas pero con la planta aún con capacidad para desarrollarse por la parte superior.

En los estudios previos en judía (Alves-Santos et al., 2002b) ya se había comprobado que la variación de la enfermedad medida por la escala CIAT, varía poco tras las cuatro semanas, pues los aislados que no han sido capaces de matar la

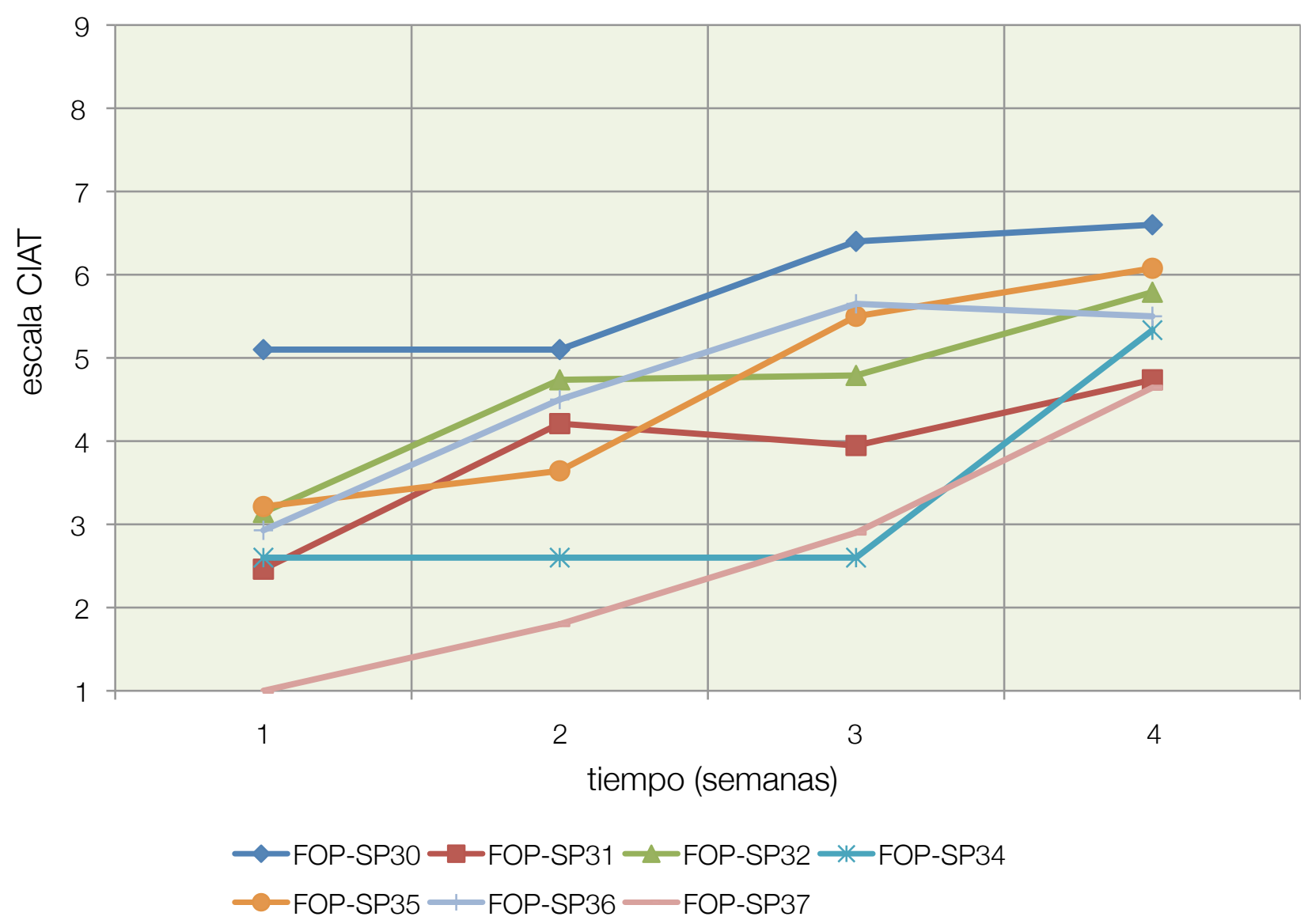

Figura 4. 4 - Virulencia de los aislados débilmente virulentos según su valor en la escala CIAT en plantas de judión ( $P$. coccineous) durante las cuatro primeras semanas de la infección. 
planta tras ese tiempo no tienen potencial suficiente para matar una planta que empieza a tener un mayor porte.

Para comprobar este resultado en judión, una muestra de de aislados de los tres tipos se prolongó en el tiempo hasta las 8 semanas. Como se presenta en la Figura 4. 6 (Pág. 75), la desviación de los resultados fue poco significativa (menor de 0,78 puntos de la escala (IAT) y por tanto los resultados y conclusiones a las ocho semanas similares a los de las cuatro semanas. En la Figura 4. 5 (Pág. 74), se resumen las conclusiones del experimento, en el que los aislados estudiados pueden ser divididos en tres grupos independientes de acuerdo a su virulencia en plantas de judión.

\subsubsection{2 - Significación estadística de los grupos de} virulencia observados

Para recoger de forma numérica la velocidad de progresión de la enfermedad, se utilizó una nueva variable numérica denominada D.P.R. (Disease progression rate) que se define como la media de la escala CIAT entre dos datos temporales (GarcíaSánchez, 2007), en este estudio entre la segunda y la cuarta semana. Se observó que los aislados supervirulentos presentaron un valor D.P.R. mayor de 8, mientras que los aislados altamente virulentos presentaron un valor de D.P.R. menor de 8, con lo que ambos se diferencian numéricamente.

Excepto en uno de los casos (D.P.R. de FOP-SP33 es 6,5), los aislados altamente virulentos presentaban D.P.R. mayor de 7 , y

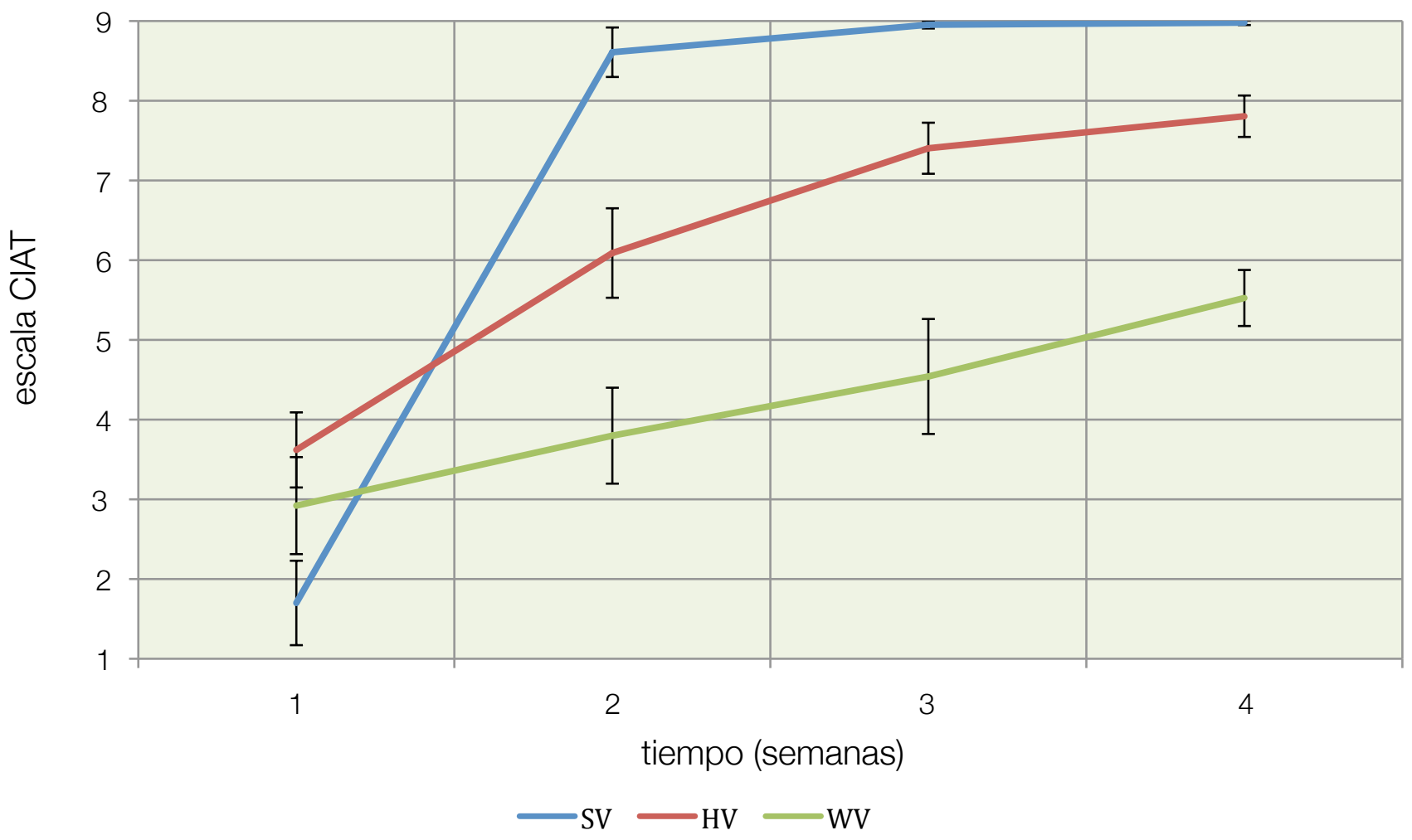

Figura 4. 5 - Media del valor medio de la escala CIAT de los aislados pertenecientes a cada uno de los grupos durante las cuatro primeras semanas de la infección. SV: Grupo de supervirulentos. HV: Grupo de altamente virulentos. WV: Grupo de débilmente virulentos. 
en todos los casos, los aislados débilmente virulentos presentaban un D.P.R. menor de 6.

Se realizó un análisis estadístico de la varianza mediante F-test (One-way ANOVA) de los datos de infección en judión de todos los aislados en la cuarta semana, que confirmó la significación estadística (se rechaza Ho: igualdad) de los grupos propuestos. Usando un intervalo de confianza del 95\% $(P=0,050)$, existe una separación estadística significativa $(P<0,050)$ entre los aislados supervirulentos con los altamente virulentos $(\mathrm{P}=0,018)$, asi como de los altamente virulentos con los débilmente virulentos $(P=0,016)$. El mismo análisis estadístico no detectó diferencias en las comparaciones entre las estirpes pertenecientes a un mismo grupo de virulencia: supervirulentos $(P=0,253)$, altamente virulentos $(P=0,143)$ y débilmente virulentos $(P=0,209)$.

\subsubsection{3 - Ensayos de patogenicidad en judía ( $P$. vulgaris)}

Los aislados que presentaban un fenotipo en judión menos virulento se han nombrado como altamente y débilmente virulentos, de la misma forma que aislados caracterizados en judía y que mostraban una evolución de la enfermedad similar.

Para comprobar si los grupos de virulencia obtenidos en judión y judía eran similares, una selección de los aislados

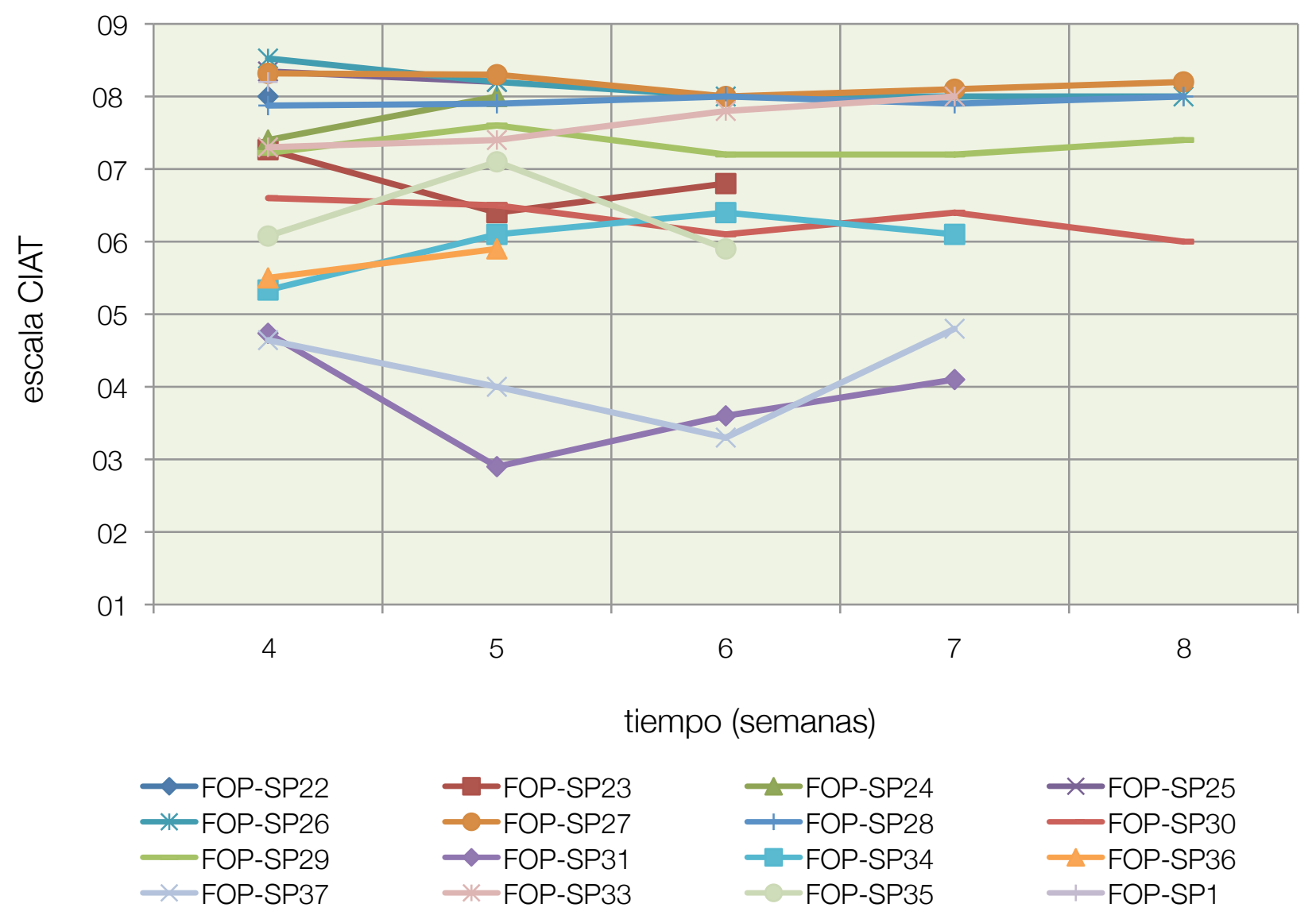

Figura 4. 6 - Virulencia de una selección de aislados altamente y débilmente virulentos en judión entre la cuarta y octava semanas tras la infección. 
menos virulentos en judión se usó para un ensayo de infección en judía.

Se observa (Figura 4.7 - Pág. 76) que los aislados débilmente virulentos en judión no se comportan como tales en judía, al contrario, su virulencia es similar a la de los aislados altamente virulentos en judía, pues matan a la mayor parte de las plantas entre la segunda y tercera semana.

Los aislados altamente y débilmente virulentos en judión son desde el punto de vista de su virulencia altamente virulentos en judía.

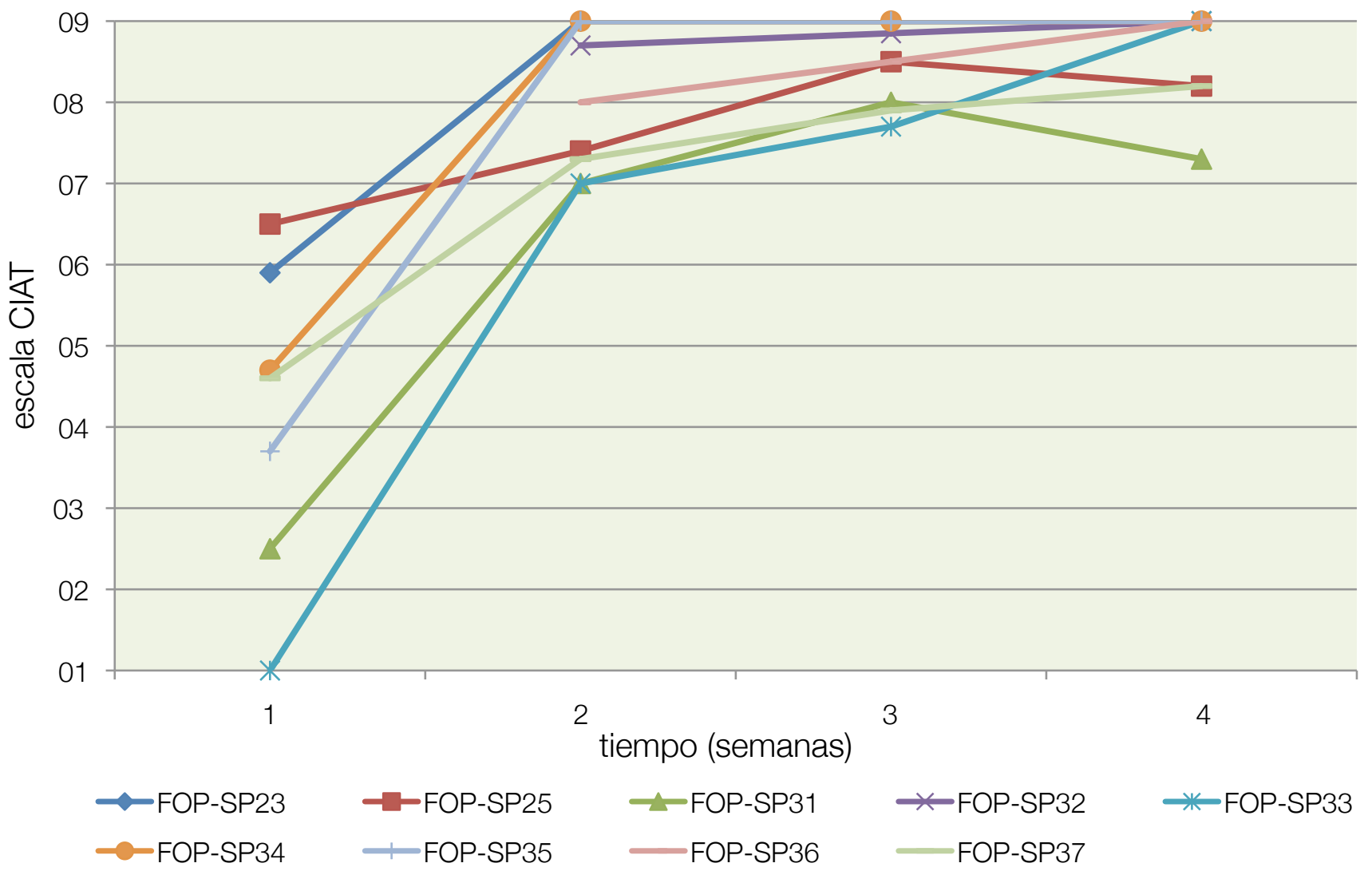

Figura 4. 7 - Virulencia de una selección de aislados altamente y débilmente virulentos en judión en plantas de judía ( $P$. vulgaris). 

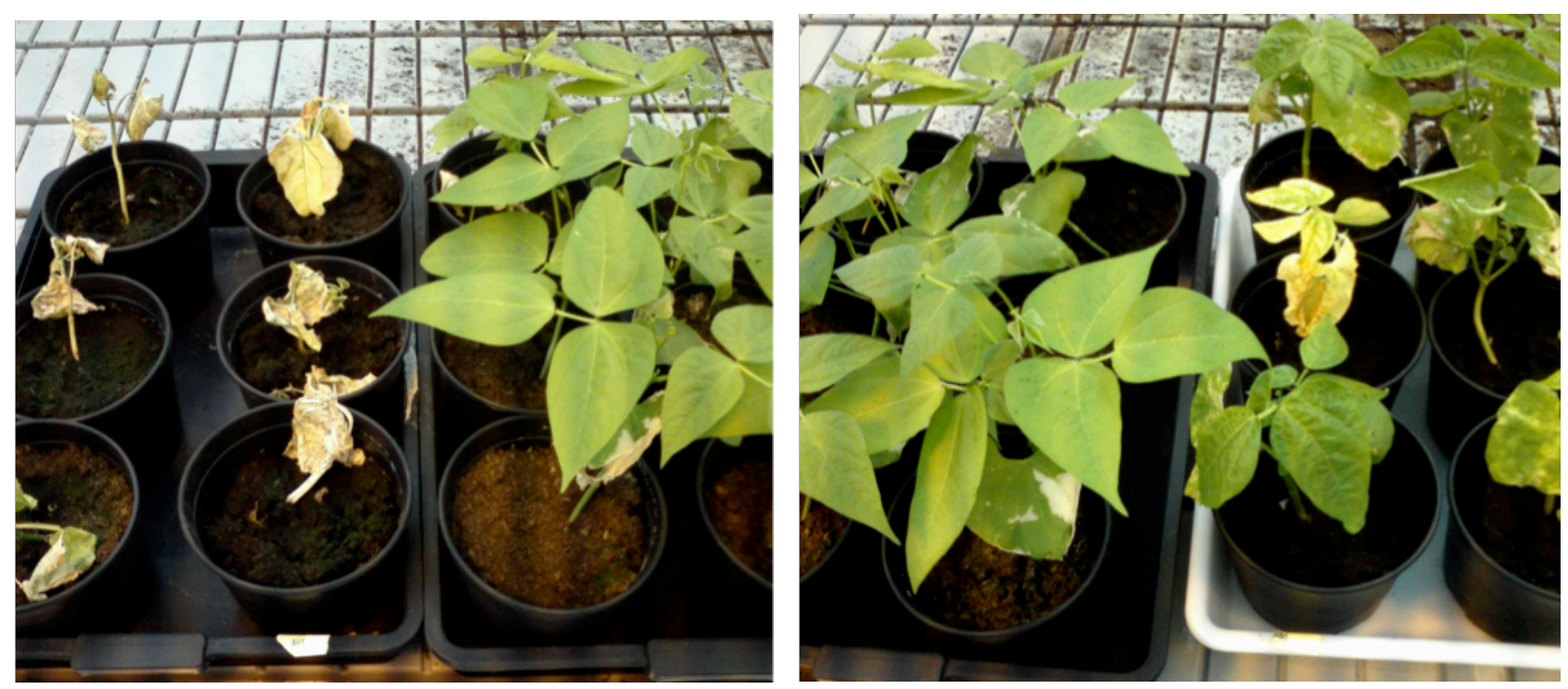

Figura 4. 8 - Ensayo de virulencia en plantas de judía a las 2 semanas tras la infección. En la foto de la izquierda se compara un grupo de plantas infectadas con un aislado supervirulento FOP-SP13 (izq.) con plantas no infectada (der.). En la foto de la derecha se comparan plantas no infectadas (izq.) con plantas infectadas con FOP-SP01 (der.).

\begin{tabular}{|cc|c|c|c|c|}
\multicolumn{7}{r}{} & \multicolumn{5}{c}{ Tiempo (semanas) } \\
& 1 & 2 & 3 & 4 & D.P.R. \\
\hline FOP-SP23 & $5,9(3,6)$ & $9,0(0,0)$ & $9,0(0,0)$ & $9,0(0,0)$ & $9,0(0,0)$ \\
\hline FOP-SP25 & $6,5(3,7)$ & $7,4(3,6)$ & $8,5(1,9)$ & $8,2(1,8)$ & $8,0(0,6)$ \\
\hline FOP-SP31 & $2,5(2,5)$ & $5,0(3,3)$ & $8,0(1,1)$ & $7,3(1,5)$ & $6,8(1,6)$ \\
\hline FOP-SP32 & - & $8,7(0,8)$ & $8,9(1,0)$ & $9,0(0,0)$ & $8,9(0,2)$ \\
\hline FOP-SP33 & $1,0(0,0)$ & $4,4(3,0)$ & $7,7(3,1)$ & $9,0(0,0)$ & $7,0(2,4)$ \\
\hline FOP-SP34 & $4,7(4,0)$ & $9,0(0,0)$ & $9,0(0,0)$ & $9,0(0,0)$ & $9,0(0,0)$ \\
\hline FOP-SP35 & $3,7(3,9)$ & $9,0(0,0)$ & $9,0(0,0)$ & $9,0(0,0)$ & $9,0(0,0)$ \\
\hline FOP-SP36 & - & $8,0(1,1)$ & $8,5(1,0)$ & $9,0(0,0)$ & $8,5(0,5)$ \\
\hline FOP-SP37 & $4,6(3,6)$ & $7,3(1,5)$ & $7,9(2,1)$ & $8,2(1,8)$ & $7,8(0,5)$ \\
\hline
\end{tabular}

Tabla 4. 1 - Virulencia cuantificada en la escala CIAT y el parámetro D.P.R. en judía. El valor en cada celda representa el valor medio de la escala CIAT de todas las plantas para el aislado en esa semana. El valor entre paréntesis es la desviación de dicho valor medio. D.P.R.: Velocidad de progresión de la enfermedad. 
tiempo (semanas)

\begin{tabular}{|c|c|c|c|c|c|}
\hline Aislados & 1 & 2 & 3 & 4 & D.P.R. \\
\hline FOP-SP13 & $3.0(2.7)$ & $8.9(0.3)$ & $9.0(0.0)$ & $9.0(0.0)$ & $9.0(0.0)$ \\
\hline FOP-SP14 & $2.1(2.6)$ & $8.9(0.3)$ & $9.0(0.0)$ & $9.0(0.0)$ & $9.0(0.0)$ \\
\hline FOP-SP15 & $1.4(1.3)$ & $9.0(0.0)$ & $9.0(0.0)$ & $9.0(0.0)$ & $9.0(0.0)$ \\
\hline FOP-SP16 & $1.0(0.0)$ & $7.4(2.7)$ & $8.8(0.6)$ & $8.8(0.6)$ & $8.3(0.7)$ \\
\hline FOP-SP17 & $1.0(0.0)$ & $7.7(1.6)$ & $8.8(0.6)$ & $9.0(0.0)$ & $8.5(0.6)$ \\
\hline FOP-SP18 & $1.0(0.0)$ & $9.0(0.0)$ & $9.0(0.0)$ & $9.0(0.0)$ & $9.0(0.0)$ \\
\hline FOP-SP19 & $1.0(0.0)$ & $9.0(0.0)$ & $9.0(0.0)$ & $9.0(0.0)$ & $9.0(0.0)$ \\
\hline FOP-SP20 & $1.0(0.0)$ & $8.7(0.9)$ & $9.0(0.0)$ & $9.0(0.0)$ & $8.9(0.1)$ \\
\hline FOP-SP21 & 3.9 (3.0) & $8.9(0.3)$ & $9.0(0.0)$ & $9.0(0.0)$ & $9.0(0.0)$ \\
\hline FOP-SP22 & $3.0(2.1)$ & $6.5(0.9)$ & $7.3(2.6)$ & $8.0(1.8)$ & $7.3(0.6)$ \\
\hline FOP-SP23 & $2.8(2.7)$ & $4.5(2.7)$ & $6.3(2.6)$ & $7.3(2.5)$ & $6.0(1.1)$ \\
\hline FOP-SP24 & $3.8(2.5)$ & $4.4(2.9)$ & $8.0(1.6)$ & $7.4(2.4)$ & $6.6(1.6)$ \\
\hline FOP-SP25 & $4.2(3.1)$ & $6.3(2.8)$ & $7.8(1.6)$ & $8.3(1.5)$ & $7.5(0.9)$ \\
\hline FOP-SP26 & $2.3(2.6)$ & $7.0(2.4)$ & $8.0(1.8)$ & $8.5(1.2)$ & $7.8(0.6)$ \\
\hline FOP-SP27 & $4.2(3.4)$ & $7.3(2.0)$ & $8.1(1.7)$ & $8.3(1.3)$ & $7.9(0.5)$ \\
\hline FOP-SP28 & $3.8(3.7)$ & $6.6(1.5)$ & $7.6(1.3)$ & $7.9(1.7)$ & $7.4(0.5)$ \\
\hline FOP-SP29 & 5.4 (3.3) & $7.1(2.1)$ & $6.8(2.2)$ & $7.2(2.3)$ & $7.0(0.2)$ \\
\hline FOP-SP30 & $5.1(1.8)$ & $5.1(1.8)$ & $6.4(1.9)$ & $6.6(1.9)$ & $6.0(0.7)$ \\
\hline FOP-SP31 & $2.5(2.9)$ & $4.2(2.6)$ & $3.9(2.9)$ & 4.7 (2.9) & $4.3(0.3)$ \\
\hline FOP-SP32 & $3.1(2.3)$ & $4.7(2.9)$ & $4.8(2.9)$ & $5.8(2.8)$ & $5.1(0.5)$ \\
\hline FOP-SP33 & $3.1(3.0)$ & $5.1(2.2)$ & $6.9(2.1)$ & 7.3 (1.8) & $6.4(1.0)$ \\
\hline FOP-SP34 & $2.6(2.1)$ & $2.6(1.4)$ & $2.6(2.3)$ & $5.3(2.6)$ & $3.5(1.3)$ \\
\hline FOP-SP35 & $3.2(2.9)$ & $3.6(2.7)$ & $5.5(1.8)$ & $6.1(2.1)$ & $5.1(1.0)$ \\
\hline FOP-SP36 & $2.9(2.4)$ & $4.5(2.4)$ & $5.7(2.4)$ & $5.5(2.6)$ & $5.2(0.5)$ \\
\hline FOP-SP37 & $1.0(0.0)$ & $1.8(1.3)$ & $2.9(1.9)$ & $4.6(3.0)$ & $3.1(1.2)$ \\
\hline FOP-SP01 & - & $5.5(1.1)$ & $8.0(1.3)$ & $8.2(1.9)$ & $7.2(1.2)$ \\
\hline
\end{tabular}

Tabla 4. 2 - Virulencia cuantificada en la escala CIAT y el parámetro D.P.R. en judión. El valor en cada celda representa el valor medio de la escala CIAT de todas las plantas para el aislado en esa semana. El valor entre paréntesis es la desviación de dicho valor medio. D.P.R.: Velocidad de progresión de la enfermedad. 


\section{nitM}

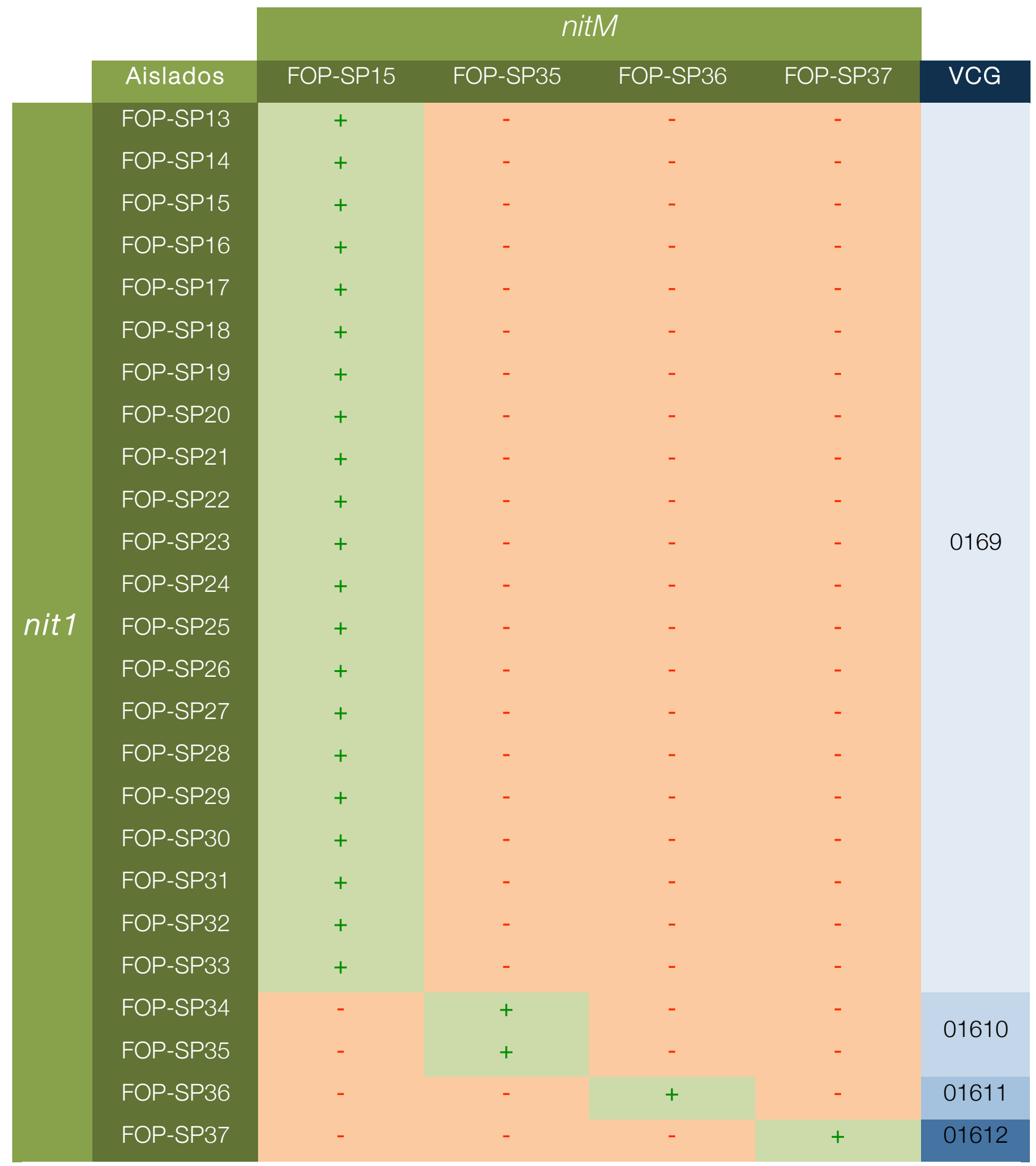

Tabla 4. 3 - Ensayos de compatibilidad vegetativa entre mutantes nit1 de las estirpes y mutantes nitN representativos y VCG resultantes. (+): Forman heterocarionte. (-): No forman heterocarionte. VCG: Vegetative Compatibillty Group o Grupo de Compatibilidad vegetativa 
4.1.2 - Grupos de compatibilidad vegetativa

Como se observa en la Tabla 4. 3 (Pág. 79), tras los emparejamientos y complementación de distintos mutantes en la ruta de asimilación del nitrógeno, se han encontrado cuatro nuevos grupos de compatibilidad vegetativa (VCG) en los 25 aislados estudiados, si bien, uno de los VCG aglutina la mayor parte de los aislados. Además de los 25 aislados obtenidos en plantas de judión se incluyeron ocho aislados adicionales en los emparejamientos, en representación de cada uno de los VCG descritos previamente para $F$. oxysporum f.sp. phaseoli. Ninguno de estos 8 aislados representativos forma un heterocarionte con ninguno de los aislados estudiados, por lo que se trata de nuevos VCG.

Demostrada su condición de patógenos, los aislados fueron renombrados siguiendo un orden secuencial que situase contiguos los aislados pertenecientes a un mismo VCG, siendo la nomenclatura que se presenta en esta tesis.

En la Tabla 4.3 (Pág. 79) se resumen los emparejamientos con un ejemplo de mutante tipo nitM por cada VCG. En el experimento se incluyeron además un mutante nitM de los aislados SP13, SP14 y SP31, que dieron resultados similares a SP15. También se comprobó que todos los aislados obtenidos fueran capaces de formar heterocariontes consigo mismo (no autoincompatibles).

El primero de los VCG, denominado 0169 (grupo 9 de Fusarium oxysporum f.sp.

\begin{tabular}{|c|c|c|c|}
\hline Aislado & $\begin{array}{l}\text { RFLP } \\
\text { IGS }\end{array}$ & Virulencia & VCG \\
\hline FOP-SP13 & A & SV & 169 \\
\hline FOP-SP14 & A & SV & 169 \\
\hline FOP-SP15 & A & SV & 169 \\
\hline FOP-SP16 & A & SV & 169 \\
\hline FOP-SP17 & A & SV & 169 \\
\hline FOP-SP18 & A & SV & 169 \\
\hline FOP-SP19 & A & SV & 169 \\
\hline FOP-SP20 & A & SV & 169 \\
\hline FOP-SP21 & A & SV & 169 \\
\hline FOP-SP22 & A & HV & 169 \\
\hline FOP-SP23 & A & HV & 169 \\
\hline FOP-SP24 & A & HV & 169 \\
\hline FOP-SP25 & A & HV & 169 \\
\hline FOP-SP26 & A & HV & 169 \\
\hline FOP-SP27 & A & HV & 169 \\
\hline FOP-SP28 & A & HV & 169 \\
\hline FOP-SP29 & A & HV & 169 \\
\hline FOP-SP30 & A & WV & 169 \\
\hline FOP-SP31 & A & WV & 169 \\
\hline FOP-SP32 & A & WV & 169 \\
\hline FOP-SP33 & B2 & HV & 169 \\
\hline FOP-SP34 & A & WV & 1610 \\
\hline FOP-SP35 & B2 & WV & 1610 \\
\hline FOP-SP36 & B2 & WV & 1611 \\
\hline FOP-SP37 & B2 & WV & 1612 \\
\hline
\end{tabular}

Tabla 4. 4 - Correspondencia entre el RFLP del IGS, grupo de virulencia y CVG para los $F$. oxysporum aislados de judión. 
phaseoli -016-) comprende 21 de los aislados, secuencialmente del SP13 al SP33. El segundo de los VCG, comprende a los aislados SP34 y SP35, y constituye el VCG 01610. Finalmente, los dos últimos VCG tienen un único miembro cada uno de ellos, constituyendo los grupos 01611 y 01612 .

\subsection{3 - Diversidad genética de los aislados}

obtenidos de judión: RFLP-IGS y mating-

type

Las diferentes digestiones del espaciador intergénico (IGS) del ADN ribosómico dieron patrones de bandas conocidos previamente en los estudios en aislados de judía. Esos patrones se corresponden con los haplotipos de IGS nombrados como haplotipo A y haplotipo B2.

Esta división en dos grupos se observa en los propios productos de PCR, con una longitud de 2,55 kbp y 2,6 kbp, para los haplotipos A y B2, respectivamente. En nuestro experimento de RFLP no se generaron patrones diferentes dentro de cada producto de PCR que permitiese su división en subgrupos.

Entre los aislados recogidos en judión, 21 presentaron un haplotipo A y solo 4 un haplotipo B2. Esta división en dos grupos no se corresponde ni con VCG ni con grupos de virulencia. En el caso más extremo, los 4 aislados con haplotipo B2 pertenecen a 4 VCG distintos.

Como ejemplo se muestra la Figura 4. 11 (Pág. 82), con la digestión por la enzima Xhol de ocho aislados con haplotipo A, y cuatro aislados con haplotipo B2, junto a tres controles de los haplotipos A, B1 y C (carriles 1 a 3).

Existen oligonucleótidos para la determinación del mating-type verificados en F. oxysporum (Yun et al., 2000). En todos los aislados se obtuvo un producto de PCR de 0,2 kbp (usando los oligonucleótidos FoMAT2P10 y FMATp2) y otro de 0,6 kbp (usando los oligonucleótidos FMATp1 y FoMAT2p2), correspondiendose ambos a diferentes fragmentos del idiomorfo denominado MAT1-2 (Figura 4. 9 - Pág. 81).

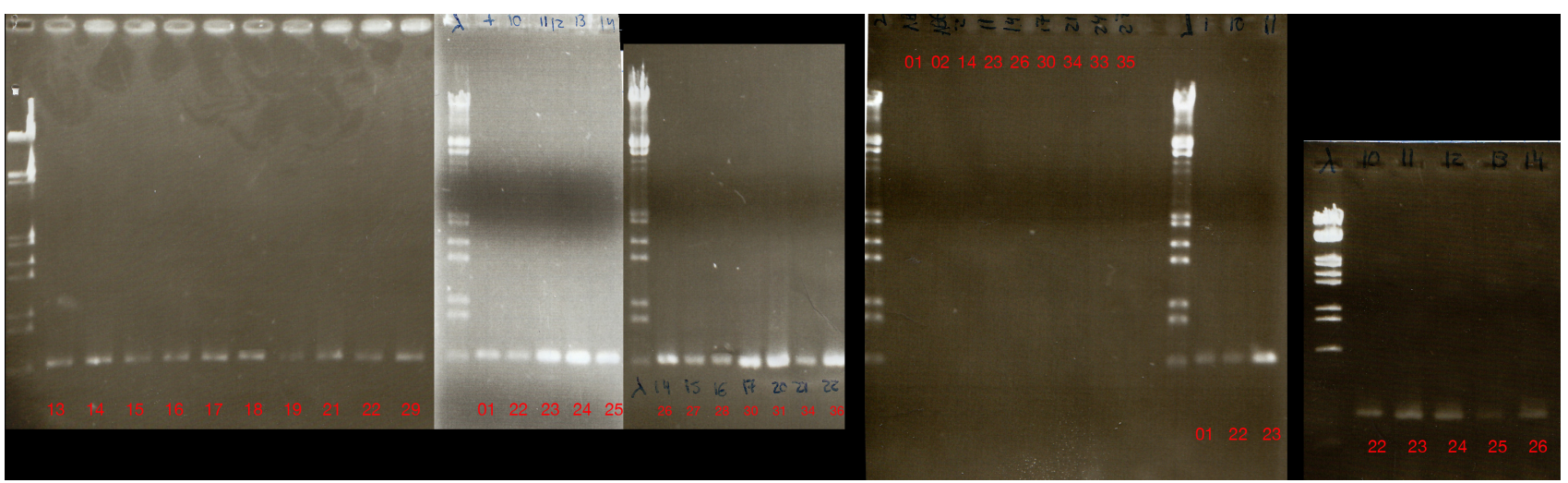

Figura 4. 9 - Amplificación mediante PCR de las regiones mating-type con los pares de oligonucleótidos FMATP1-FoMAT2p2 (los tres geles de agarosa de la izq.), FoMAT1-2p1FoMAT1-2p2 (cuarto por la izq.) y FoMAT2P10-FMATp2 (quinto por la izq.). Los número en rojo indican el nombre de la estirpe (FOP-SPXX). Las anotaciones a mano en algunos carriles se corresponden con los nombres de colección (AV-XX). 
En ningún caso se obtuvo producto de PCR cuando se probó con los oligonucleótidos FoMAT1-2p1 y FoMAT1-2p2, que amplificarían una región de $1,5 \mathrm{kbp}$ del idiomorfo denominado MAT1-1.

\subsection{4 - Presencia de ftf1 y ftf2 en los aislados recogidos en judión}

Mediante hibridaciones tipo Southern pretendiamos conocer el número de copias de los factores de transcripción ftf1 y ftf2 en los aislados recogidos en judión. Para ello se usaron tres sondas previamente usadas en la caracterización de aislados obtenidos en judía, cuyos resultados sirven de control.

En total se utilizaron tres membranas diferentes con una selección de aislados recogidos en judión pertenecientes a distintos grupos de patogenicidad y compatibilidad

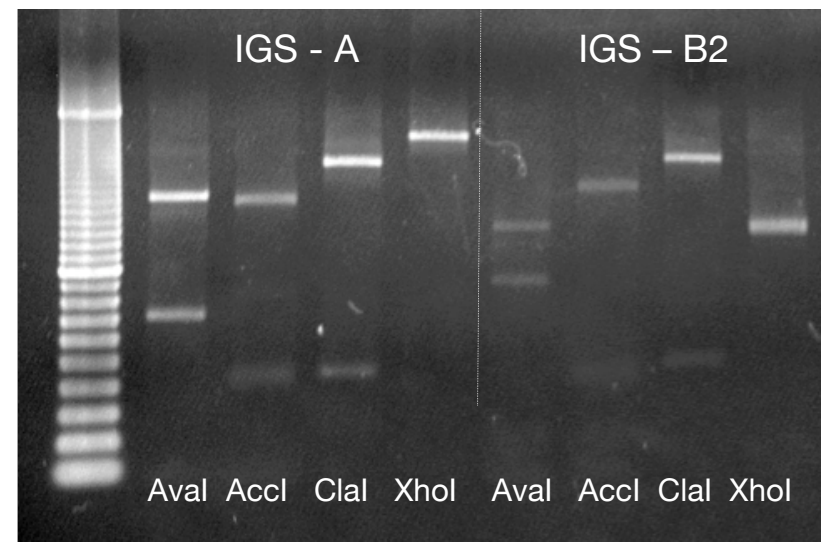

Figura 4. 10 - Modelos de patrones de bandas de digestiones del IGS de una muestra con haplotipo A (carriles 1 a 4) y otra B2 (carriles 5 a 8). Digerido con Aval (1 y 5), Accl (2 y 6), Clal (3 y 7) y Xhol (4 y 8). Marcador de tamaño de $100 \mathrm{bp}$.

vegetativa. Se cuidó de seleccionar aislados pertenecientes a la minoría con haplotipo B2 del IGS.

La primera de las membranas contenía el ADN digerido con HindIII de nueve aislados de $F$. oxysporum obtenidos en judión, tres de cada uno de los grupos de patogenicidad. En la Figura 4. 14 (Pág. 85) se

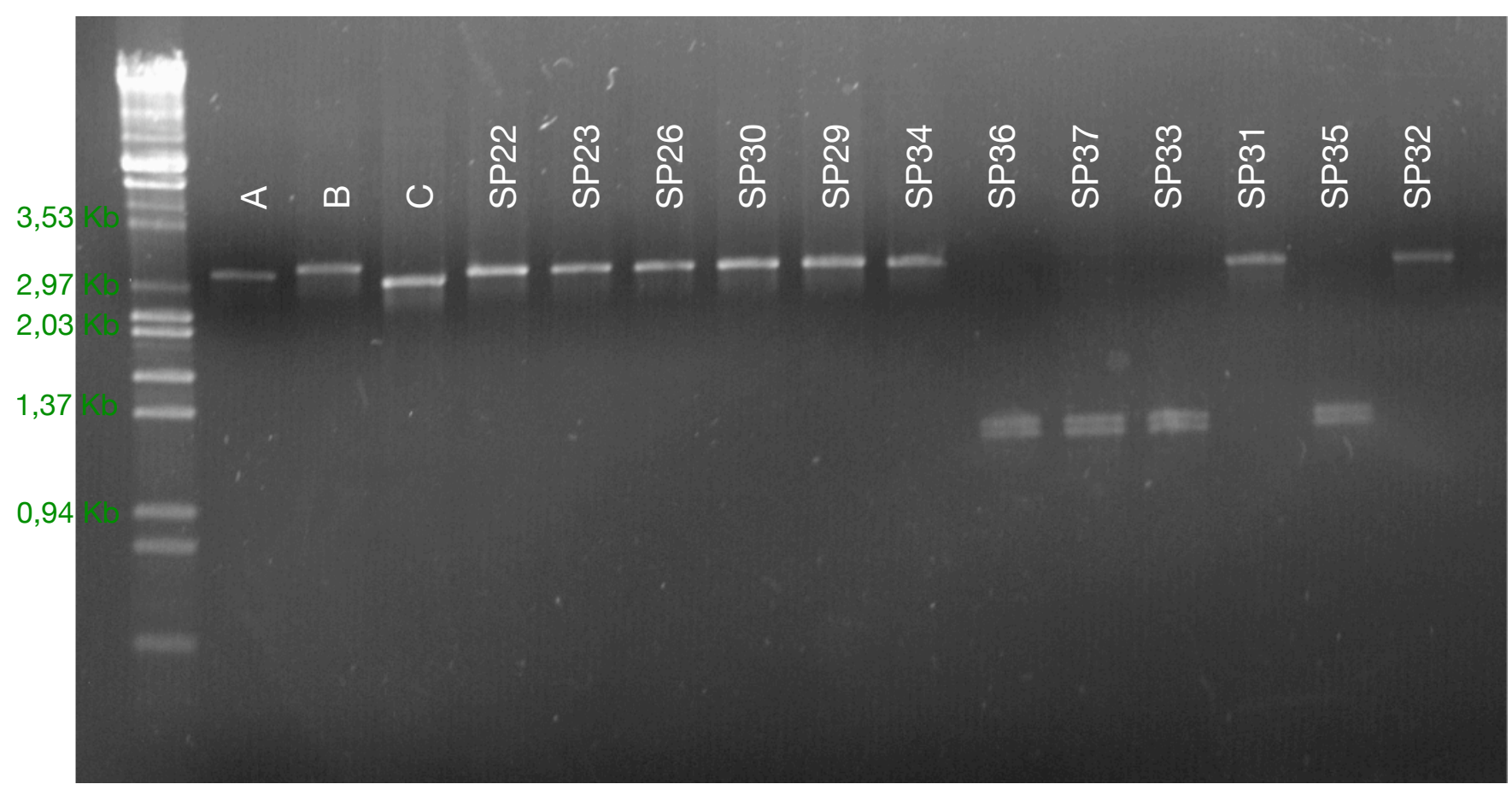

Figura 4. 11 - Digestión con la enzima Xhol de (de izq. A der.) tres aislados control de los haplotipos A (1), B (2) y C (3), y los aislados SP22, SP23, SP26, SP30, SP29, SP34 (los seis IGS-A), SP36, SP37, SP33 (los tres IGS-B), SP31 (IGS-A), SP35 (IGS-B) y SP32 (IGS-A). Marcador de tamaño: 0,56 kbp, 0,83 kbp, 0,94 kbp, 1,37 kbp, 1,57 kbp, 1,91 kbp, 2,03 kbp, 2,97 kbp, 3,53 kbp, 4,27 kbp, 4,97 kbp. 
muestran los resultados de las dos hibridaciones tipo Southern que se hicieron con el mismo. El cuarto carril (SP32) presenta un error probablemente durante la digestión con HindIII.

Se usó una sonda perteneciente al comienzo de la región codificante (B5-M17A) que incluye el dominio dedo de zinc binuclear y otra de la región del promotor inmediatamente anterior a la región codificante (B310-A280) (Figura 4. 12 - Pág. 83).

Primero, la sonda B5-M17A (parte izquierda de la Figura 4. 14) detectó un gran número de señales de diverso tipo. Todos los aislados mostraron al menos cinco bandas intensas (flechas rojas): dos en la parte inferior entorno a $1,9 \mathrm{kbp}$ y $2,1 \mathrm{kbp}$, y tres más en la parte superior entorno a las $5 \mathrm{kbp}$, $6 \mathrm{kbp}$ y $8 \mathrm{kbp}$.

Por el contrario, existen dos bandas con diferencias entre los aislados con distinta virulencia. Una banda de 5,2 kbp que no existía en el aislado SP32 (carril 7), y una banda de $7 \mathrm{kbp}$ (flecha azul) que no existía en los aislados SP32, SP33 y SP34 (carriles 7, 8 y 9 , respectivamente). Esta última banda

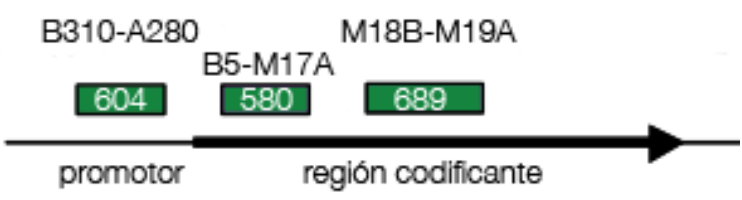

Figura 4. 12 - Sondas usadas en las hibridaciones tipo Southern. Posición de las sondas (cuadrados verdes) respecto a la secuencia de ftf1 (flecha negra). En el interior se indica la longitud de las mismas (bp) y sobre los cuadrados los oligonucleótidos usados para amplificarlas. apareció en los tres aislados supervirulentos (SP13, SP17 y SP21). También se encontró en uno de los aislados altamente virulentos (SP29) pero no en el otro (SP33). Y así mismo, aparecieron en uno de los aislados débilmente virulentos (SP31) pero no en los otros dos (SP32 y SP34). Aunque no existe relacción clara entre ninguno de los grupos obtenidos (virulencia, RFLP-IGS o VCG), si existe sesgo con respecto a los grupos de virulencia.

Posteriormente, la hibridización Southern con la sonda de la región promotora (B310-A280) detectó un menor número de bandas que la anterior. Hasta cinco bandas claras a la que se añade una señal residual en tamaños mayores de $10 \mathrm{kbp}$ en algunos aislados.

Cuatro de las bandas aparecieron en todos los aislados (con excepción de SP32) y se corresponden con las cuatro copias polimórficas que se habían también observado en estudios anteriores (Ramos et al., 2007) con la misma sonda en aislados obtenidos en judía. En esta membrana, el aislado SP32 presentó solo tres copias polimórficas que hibriden con el promotor, si bien en otras hibridizaciones con la sonda M18B-M19 si contenía las cuatro bandas.

La quinta banda se corresponde con la copia polimórfica diferencial de unos $7 \mathrm{kbp}$ que se había observado en la misma membrana con la otra sonda perteneciente a la región codificante.

Para comprobar los resultados usamos dos membranas nuevas (Figura 4. 13 - Pág. 85) partiendo de dos digestiones 
independientes pero con el mismo ADN, incluyendo una distribución similar de aislados, e incorporando también una muestra de aislados obtenidos en judía usados en los estudios anteriores, para comprobar que eran exactamente las mismas señales. Estas membranas se hibridaron con una sonda de la región codificante pero que no incluye el dominio conservado dedo de zinc binuclear (M18B-M19A).

En estas hibridaciones Southern apareció una señal común a todos los aislados entorno a $3,8 \mathrm{kbp}$, tanto los obtenidos en judía como en judión, independientemente de su virulencia. Esta banda ha sido identificada como un fragmento del gen ftf2 y está presente además en otras formas especiales de $F$. oxysporum (como se verá en el apartado 4.2.1.3). Es la única banda que encontramos en los aislados no patógeno $A B 7$ (carril 8) y débilmente virulento en judía SP4 (carriles 9 y 30), e igualmente es la única banda observable en los aislados débilmente virulentos en judión SP36 (carriles 12 y 27) y SP37 (carriles 11 y 28), pero que si se comportaron como altamente virulentos en judía.

La mayor parte de los aislados mostró, además, cuatro bandas que se corresponden con las cuatro señales observadas con la sonda B310-A280 y previamente identificada en los aislados altamente virulentos en judía como un fragmento del gen SP1 (carriles 10 y 29) y SP3 (carril 31), y que se corresponde con las cuatro copias detectadas de ftf1. Entre los $F$. oxysporum aislados de judión, estas cuatro copias aparecen en SP32 (carriles 7 y 23), SP33 (carriles 15 y 24) y SP34 (carriles 14 y 25).

Con la sonda M18B-M19A, varios aislados mostraron una quinta señal en el mismo punto que con las otras sondas, y que no aparece en ningún aislado de judía. Se verificó que existe en todos los aislados supervirulentos estudiados: SP13 (carriles 1 y 16), SP17 (carriles 2 y 17) y SP21 (carriles 3 y 18). Se comprobó también los resultados previos, esto es, que existe en SP29 (carriles 5 y 21) pero no en SP33 (como se ha visto, carriles 15 y 24). Asi mismo, se verificó que existe en un nuevo aislado altamente virulento en judión como SP22 (carril 4). También se comprobó que el ADN de SP28 está degradado (carriles 19 y 20, iguales entre si). E igualmente, también se verificó que un aislado aparentemente débilmente virulento en judión, como SP31 presenta la quinta copia (carril 6), si bien no se puede comprobar por tercera vez al estar parcialmente digerido en el carril 22. 


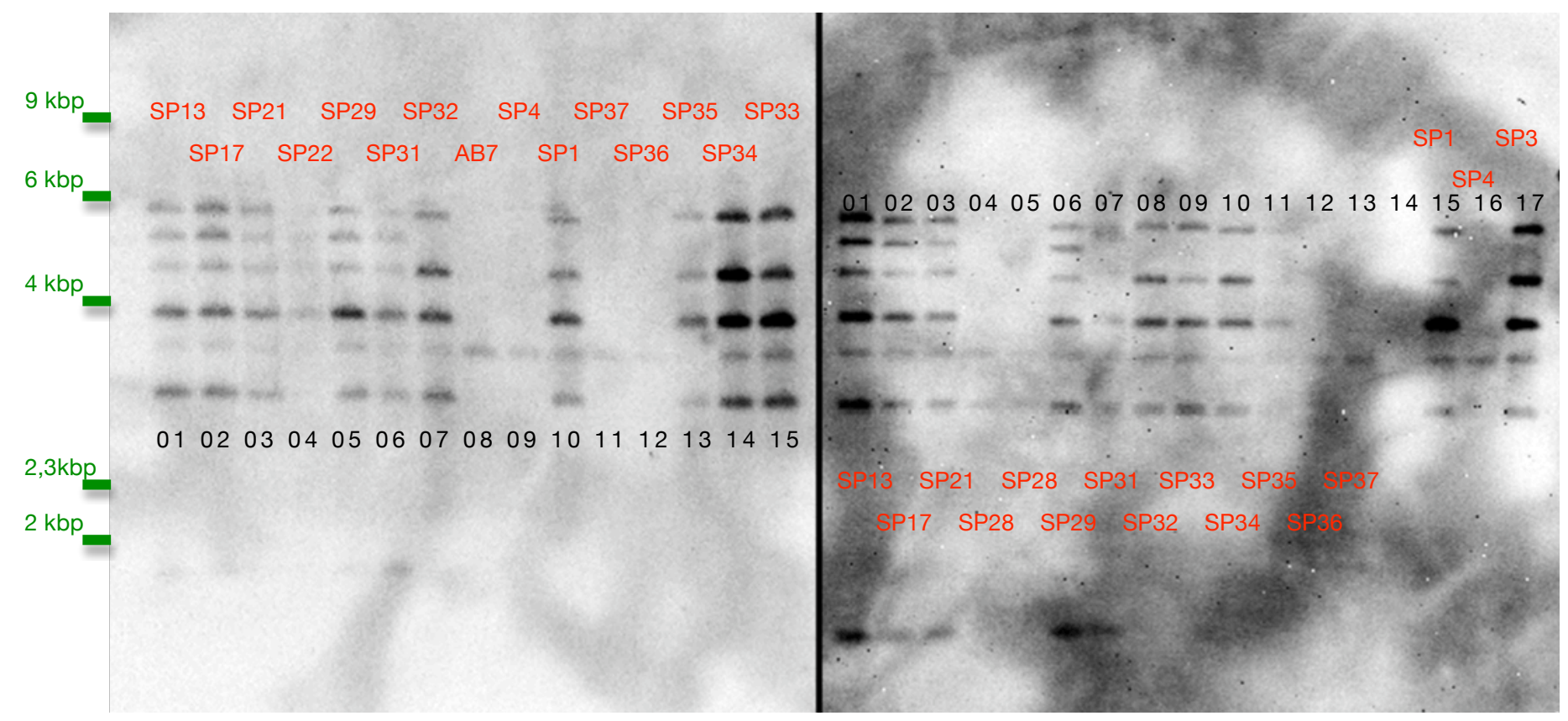

Figura 4. 13 - Hibridaciones Southern de ADN digerido con HindIII de estirpes de F. oxysporum aisladas en judión e hibridado con la sonda M18B-M19A

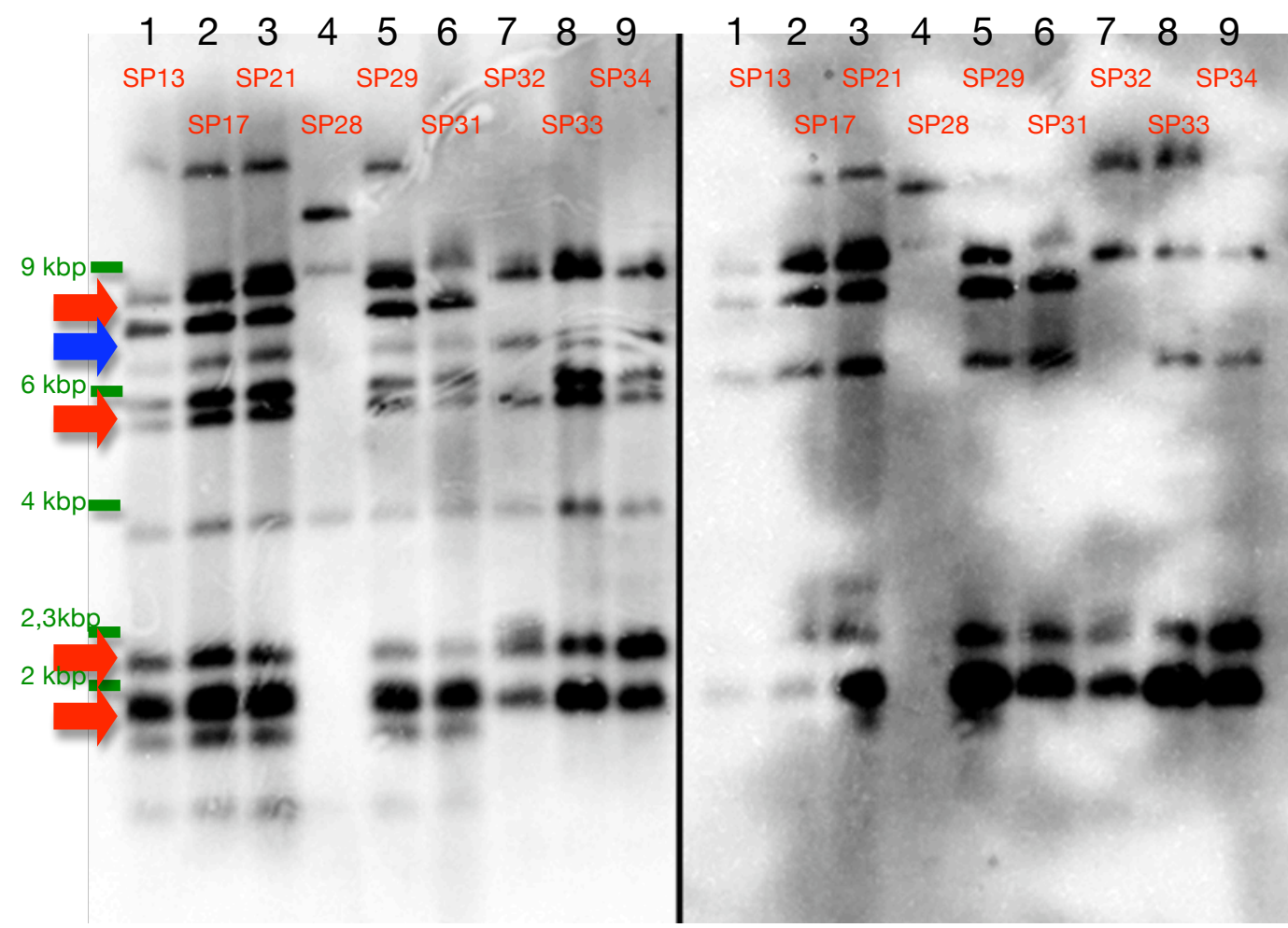

Figura 4. 14 - Hibridaciones Southern de ADN digerido con HindIII de estirpes de F. oxysporum aisladas en judión e hibridada con las sondas B5-M17A (izq.) y B310-A280 (der.). 



\section{2 - Expresión de los genes fff1 y fte en aislados silvestres \\ de Fusarium oxysporum}

\subsection{1 - Expresión del gen ftf2 en aislados silvestres}

con distinta virulencia

El factor de transcripción ftf2 está presente en una copia única en $F$. oxysporum (Ramos, 2005), así como en un importante rango de hongos filamentosos, como se verá en el apartado 4.3.1.1.

El estudio mediante PCR cuantitativa en tiempo real (o Real-time $P C R$ ) de la expresión del gen ftf2 permite profundizar en el estudio de su función.

Los oligonucleótidos que se han diseñado hibridan específicamente en un fragmento de la región codificante de ftf2 que es diferente en $f t f 1$, por lo tanto son específicos para la detección de ftf2. Esto nos ha permitido estudiar la expresión de ftf2 en fondos genéticos que también contienen ftf1. Estos oligonucleótidos se denominan ftf2_espe3_FWD y ftf2_espe3_REV.

\subsubsection{1 - Expresión de ftf2 en cultivo líquido}

Se analizó la expresión de ftf2 en tres estirpes pertenecientes a distintos grupos de virulencia: altamente virulentos (SP1), débilmente virulentos (SP4) y no patógenos

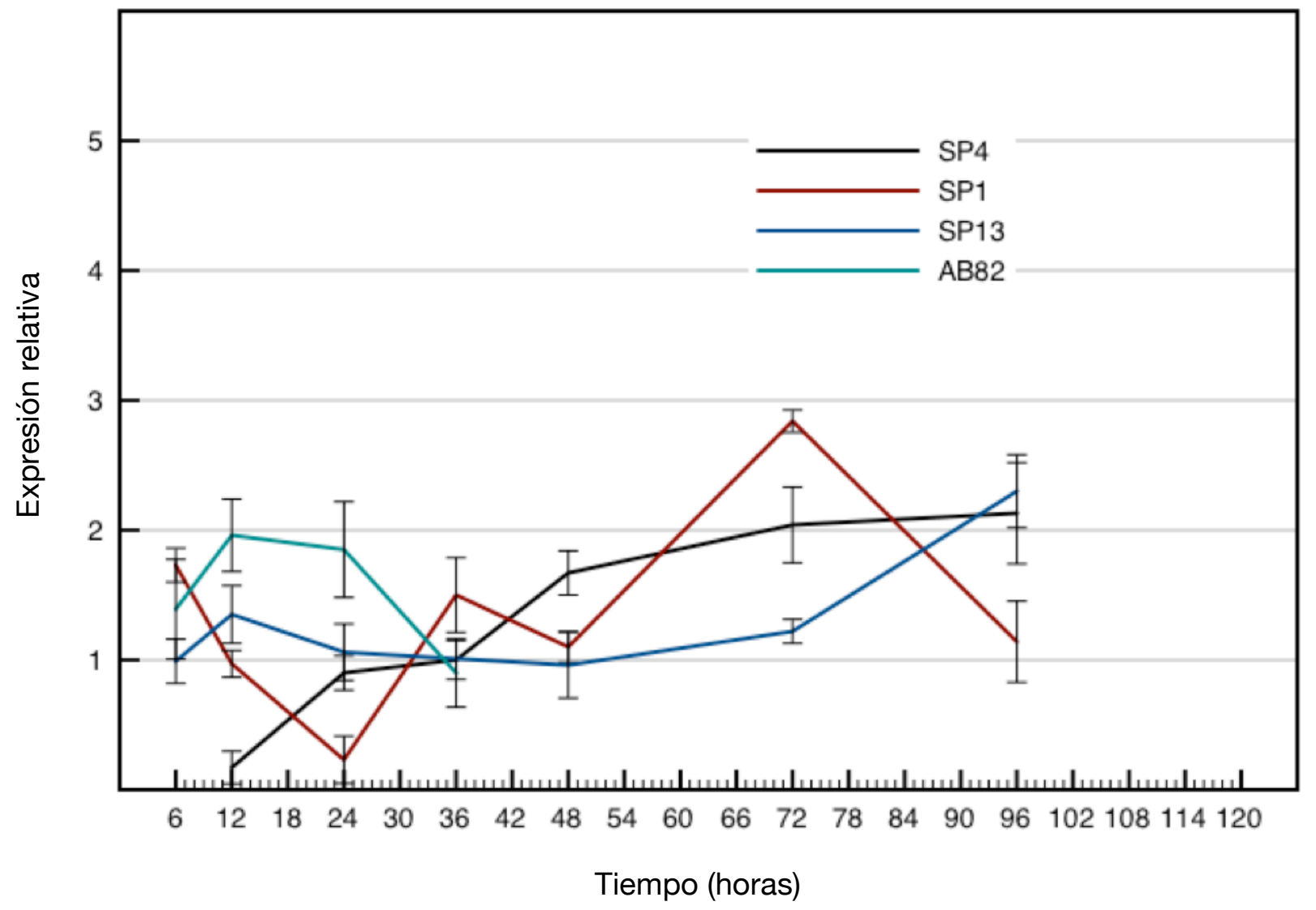

Figura 4. 15 - Expresión relativa del gen ftf2 a lo largo del tiempo (en horas) en cultivos en medio líquido en una estirpe supervirulenta (SP13), altamente virulenta (SP1), débilmente virulenta (SP4) y no patógena (AB82). 
(AB82) (Tabla 4. 5 - Pág. 88). Así mismo, se estudió la expresión de ftf2 en un aislado supervirulento, perteneciente a un nuevo grupo de virulencia descrito en el apartado anterior (4.1). Para poder comparar la expresión en los cuatro aislados, todas las gráficas se han normalizado respecto a un valor medio, en concreto la expresión del gen ftf2 en el aislado SP4 después de tres días creciendo en medio líquido.

Como se observa en la Figura 4. 15 (Pág. 87), la expresión de ftf2 para cada aislado estudiado tiene un perfil característico, si bien no se observan diferencias notables entre estirpes.

Según el perfil de expresión de SP4, un aislado débilmente virulento y con una copia de ftf2 y ninguna de $f t f 1$, la expresión

\begin{tabular}{|c|c|c|c|c|c|}
\hline Muestra & $\mathrm{Ct}$ & $\mathrm{dCt}$ & dCt std err & $\mathrm{ddCt}$ & $\mathrm{RQ}$ \\
\hline SP4 - $12 \mathrm{~h}$ & 18,431 & 3,163 & 0,126 & 2,58 & 0,17 \\
\hline $\mathrm{SP} 4-24 \mathrm{~h}$ & 19,298 & 0,737 & 0,133 & 0,15 & 0,90 \\
\hline$\underline{\mathrm{SP} 4-36 \mathrm{~h}}$ & $\underline{20,214}$ & $\underline{0,584}$ & $\underline{0,149}$ & $\underline{0,00}$ & 1,00 \\
\hline $\mathrm{SP} 4-48 \mathrm{~h}$ & 17,822 & $-0,155$ & 0,170 & $-0,74$ & 1,67 \\
\hline $\mathrm{SP} 4-72 \mathrm{~h}$ & 17,007 & $-0,445$ & 0,292 & $-1,03$ & 2,04 \\
\hline SP4 - $96 \mathrm{~h}$ & 19,451 & $-0,504$ & 0,390 & $-1,09$ & 2,13 \\
\hline SP1-06 h & 22,536 & $-0,208$ & 0,131 & $-0,79$ & 1,73 \\
\hline SP1 - $12 \mathrm{~h}$ & 21,212 & 0,630 & 0,103 & 0,05 & 0,97 \\
\hline $\mathrm{SP} 1-24 \mathrm{~h}$ & 22,242 & 2,702 & 0,183 & 2,12 & 0,23 \\
\hline SP1-36 h & 19,759 & 0,003 & 0,288 & $-0,58$ & 1,50 \\
\hline SP1- 48 h & 20,842 & 0,448 & 0,119 & $-0,14$ & 1,10 \\
\hline SP1 - $72 \mathrm{~h}$ & 19,688 & $-0,923$ & 0,086 & $-1,51$ & 2,84 \\
\hline $\mathrm{SP} 1-96 \mathrm{~h}$ & 21,366 & 0,389 & 0,312 & $-0,20$ & 1,14 \\
\hline SP13-06 h & 20,626 & 0,597 & 0,170 & 0,01 & 0,99 \\
\hline SP13-12h & 20,313 & 0,151 & 0,222 & $-0,43$ & 1,35 \\
\hline SP13-24h & 19,382 & 0,505 & 0,217 & $-0,08$ & 1,06 \\
\hline SP13-48h & 19,847 & 0,650 & 0,254 & 0,07 & 0,96 \\
\hline SP13 - $72 \mathrm{~h}$ & 18,342 & 0,303 & 0,092 & $-0,28$ & 1,22 \\
\hline SP13-96h & 17,789 & $-0,615$ & 0,281 & $-1,20$ & 2,30 \\
\hline AB82 - $06 \mathrm{~h}$ & 24,123 & 0,112 & 0,384 & $-0,47$ & 1,39 \\
\hline AB82 - $12 h$ & 22,334 & $-0,384$ & 0,279 & $-0,97$ & 1,96 \\
\hline AB82 - $24 h$ & 26,083 & $-0,305$ & 0,369 & $-0,89$ & 1,85 \\
\hline AB82 - $36 \mathrm{~h}$ & 26,881 & 0,741 & 0,264 & 0,16 & 0,90 \\
\hline
\end{tabular}

Tabla 4. 5 - PCR cuantitativa en tiempo real específica para la detección de la expresión del gen ftf2 a distintos tiempos de crecimiento en cultivo líquido tras la inoculación. Los valores subrayados se tomaron como referencia para la normalización. 
del gen parte de un mínimo a las 12 horas y se incrementa primero rápidamente hasta alcanzar las 24 horas, y después más lentamente hasta que el segundo día se estabiliza entorno a unos valores constantes para el resto de los tiempos.

La expresión de ftf2 en el aislado altamente virulento SP1 presenta un perfil singular. Se observa un mínimo de expresión a las 24 horas que rápidamente se incrementa. En lugar de estabilizarse, a las 72 horas presenta un pico de expresión. La expresión de ftf2 en SP1 detectada a tiempos muy cortos de 6 y 12 horas es mayor que la obtenida para las 24 horas y equivalente a la de los tiempos más largos, de forma que el perfil de expresión presenta un valle a las 24 horas. Esta singularidad se observó en todas las repeticiones.

Esa singularidad del perfil de SP1, no se observa en el perfil de expresión de SP13, un aislado altamente virulento que se diferencia del anterior por tener una copia adicional de ftf1. Presenta un perfil constante desde el principio y estable entorno a un valor que en terminos generales se asemeja más al que acaba alcanzando SP4, que al de SP1 que es menor.

También se examinó la expresión de un aislado no patógeno (AB82) a tiempos cortos. Esta estirpe presenta una copia de ftf2, al igual que las estirpes patogénicas estudiadas. A diferencia de estas no presenta un mínimo de expresión a las 6 horas que

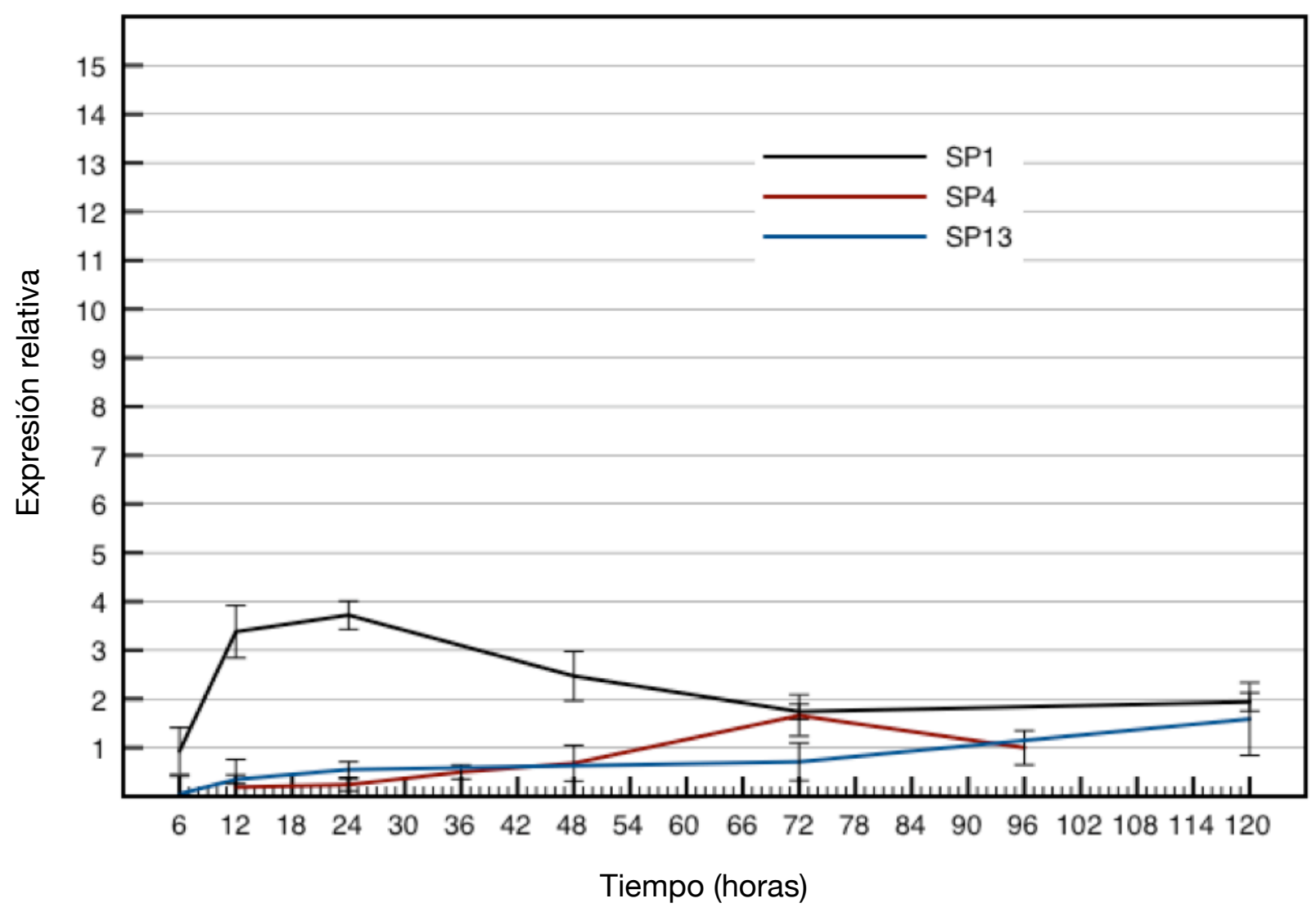

Figura 4. 16 - Expresión relativa del gen ftf2 a lo largo del tiempo (en horas) de crecimiento durante la infección en plantas de judía ( $P$. vulgaris) de una estirpe supervirulenta (SP13), altamente virulenta (SP1) y débilmente virulenta (SP4). 
rápidamente se incrementa, si no que presenta una expresión más constante en los tiempos examinados, y con valores absolutos similares, si no mayores, a los observados en los aislados patógenos.

\subsubsection{2 - Expresión de ftf2 durante la infección}

Se estudió la expresión de ftf2 durante el proceso de infección (Tabla 4. 6 - Pág. 90) en tres aislados diferentes característicos de cada uno de los patotipos descritos: supervirulentos (SP13), altamente virulentos (SP1) y débilmente virulentos (SP4). Con el objeto de poder estudiarlos en conjunto los tres patrones o perfiles de presión están normalizados respecto de la expresión de ftf2 en el aislado SP4 96 horas después de la infección, cuando ha alcanzado un valor estable en el tiempo que es equivalente entre las tres estirpes.

El perfil de expresión de ftf2 durante la infección en plantas de judía ( $P$. vulgaris) en las tres estirpes se presenta en la Figura 4. 16 (Pág. 89).

El perfil de expresión de ftf2 en SP4 en ensayo de infección es muy parecido al obtenido en cultivo líquido, pues presenta un

\begin{tabular}{|c|c|c|c|c|c|}
\hline Muestra & Ct & $\mathrm{dCt}$ & dCt std err & $\mathrm{ddCt}$ & $\mathrm{RQ}$ \\
\hline SP4 - 12 hpi & 35,687 & 11,624 & 0,570 & 2,39 & 0,19 \\
\hline SP4 - 24 hpi & 33,578 & 10,303 & 0,125 & 2,07 & 0,24 \\
\hline SP4 - 36 hpi & 34,932 & 9,232 & 0,144 & 1,00 & 0,50 \\
\hline SP4 - 48 hpi & 32,132 & 8,783 & 0,367 & 0,55 & 0,68 \\
\hline SP4 - 72 hpi & 32,287 & 7,496 & 0,425 & $-0,73$ & 1,66 \\
\hline$\underline{\text { SP4 - } 96 \text { hpi }}$ & $\underline{30,121}$ & $\underline{8,230}$ & $\underline{0,349}$ & $\underline{0,00}$ & $\underline{1,00}$ \\
\hline SP1 - 06 hpi & 32,668 & 8,331 & 0,481 & 0,10 & 0,93 \\
\hline SP1 - 12 hpi & 32,416 & 6,471 & 0,539 & $-1,76$ & 3,38 \\
\hline SP1 - 24 hpi & 31,589 & 6,333 & 0,290 & $-1,90$ & 3,72 \\
\hline SP1 - 48 hpi & 30,324 & 6,923 & 0,504 & $-1,31$ & 2,47 \\
\hline SP1 - 72 hpi & 29,801 & 7,432 & 0,155 & $-0,80$ & 1,74 \\
\hline SP1-120 hpi & 29,940 & 7,273 & 0,188 & $-0,96$ & 1,94 \\
\hline SP13 - 06 hpi & 29,866 & 12,604 & 0,369 & 4,37 & 0,05 \\
\hline SP13 - 12 hpi & 26,149 & 9,757 & 0,092 & 1,53 & 0,35 \\
\hline SP13 - 24 hpi & 34,032 & 9,105 & 0,160 & 0,88 & 0,55 \\
\hline SP13 - 72 hpi & 34,385 & 8,727 & 0,387 & 0,50 & 0,71 \\
\hline SP13-120 hpi & 31,743 & 7,557 & 0,749 & $-0,67$ & 1,59 \\
\hline
\end{tabular}

Tabla 4. 6 - PCR cuantitativa en tiempo real específica para la detección de la expresión del gen ftf2 a distintos tiempos de crecimiento tras la infección en planta de judía. Los valores subrayados se tomaron como referencia para la normalización. 
mínimo de expresión en el tiempo más corto estudiado, 12 horas tras la infección, y la expresión del gen aumenta progresivamente hasta estabilizarse a tiempos más largos. Sin embargo, este incremento progresivo de la expresión es más lento que en medio líquido, necesitando en la planta unas 48 horas para alcanzar la media estable, mientras que en cultivo líquido se estabiliza prácticamente en los mismos valores a las 24 horas.

En el caso de SP1, existe una mayor diferencia entre los dos ensayos, pues no se observa en infección el singular descenso de expresión a las 24 horas del ensayo en cultivo líquido. La expresión no decrece, si no que aumenta ligeramente en las primeras 12 horas hasta alcanzar un máximo, para después disminuir progresivamente en el tiempo hasta estabilizarse. Si bien se observa que el valor al que se estabiliza la expresión a mayores tiempos, es mayor en SP1 que en SP4.

La expresión de ftf2 en el aislado supervirulento SP13 es prácticamente igual a la expresión del aislado débilmente virulento SP4. El perfil de expresión de ftf2 en ambos parte a las 6 horas de niveles muy bajos, aumenta ligeramente a las 12 horas tras la infección, y a las 24 horas tras la infección se estabiliza en valores parecidos en ambos casos, ligeramente mayores en SP13 en las últimas horas.
4.2.2 - Expresión de ftt1 en aislados

supervirulentos

\subsubsection{1 - Expresión de ftf1 en aislados supervirulentos en cultivo líquido}

La expresión de ftf1 se estudió mediante Real-time PCR. Ya había sido estudiada previamente, tanto en placa como en ensayo de infección, mediante hibridación tipo northern, RT-PCR y PCR cuantitativa absoluta con sondas tipo Taqman (Ramos et al., 2007). En este trabajo se estudió mediante PCR cuantitativa relativa $y$ detección mediante SYBR Green, con el objeto de validar los resultados y métodos respecto a trabajos anteriores, así como ampliarlos a aislados supervirulentos.

Para ello se diseñaron oligonucleótidos específicos para ftf1 y su uso con SYBR Green. Se denominan ftf1_espe4_FWD y ftf1_espe4_REV.

En la Figura 4. 17 (Pág. 92) se presenta el patrón de expresión en el tiempo de ftf1 en cultivo líquido.

En el caso de la estirpe altamente virulenta SP1, no se observan variaciones a lo largo del tiempo, ni siquiera a los tiempos más cortos como 6 horas. Tampoco se parece al perfil de expresión de ftf2 en SP1 en cultivo líquido, pues este último presenta un valle con un mínimo a las 24 horas, que en ftf1 no existe.

Con el objeto de poder comparar la expresión de ftf1 en SP13 con la de SP1, los resultados se han normalizado, al igual que en la gráfica anterior, con la expresión de ftf1 
en SP1 a las 6 horas. El perfil de expresión del gen $f t f 2$ en la estirpe supervirulenta SP13 obtenido en cultivo líquido, es similar al de ftf2 en el mismo aislado y medio. Además, el valor de expresión medio de ftf1 en cultivo líquido en el aislado supervirulento SP13 es ligeramente menor que en el aislado altamento virulento SP1.

\subsubsection{2 - Expresión de ftf1 en aislados}

supervirulentos durante el proceso de infección

La expresión de ftf1 durante la infección se volvió a estudiar con nuevas técnicas (Figura 4. 18 - Pág. 94). Se observa un perfil con un claro incremento de expresión en las primeras horas, que alcanza su cenit entre las 12 y las 24 horas tras la infección, y un posterior descenso a niveles basales constantes.

La expresión de ftf1 en SP13 durante la infección es distinta a SP1. Para poder comparar las gráficas de SP1 y SP13, ambas están normalizadas respecto al valor de SP1 a las 120 horas tras la infección, que es el nivel basal.

En el caso de SP1 presenta un pico a las 12 horas, de entorno a 11 veces más que el nivel basal. El incremento de expresión se mantiene durante las 48 primeras horas, en nivel aún altos de entorno a cinco veces más que el nivel basal.

El aislado supervirulento SP13 presenta un pico de expresión del gen ftf1 en las primeras horas, al igual que el aislado altamente virulento SP1. El pico de expresión es mayor alcanzando casi 15 veces más que el nivel basal, lo que supone

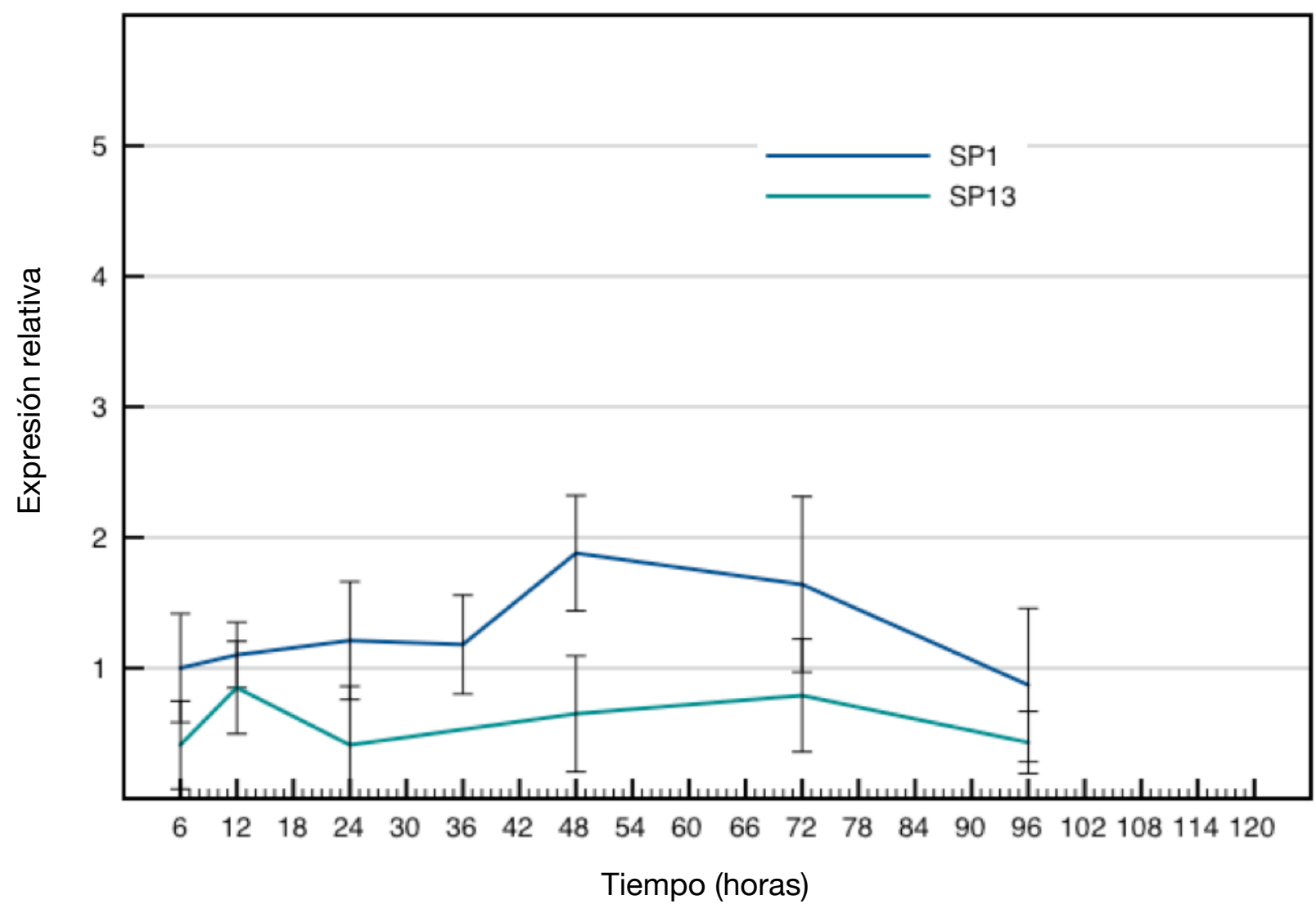

Figura 4. 17 Expresión relativa del gen ftf1 a lo largo del tiempo (en horas) en cultivos en medio líquido de estirpes supervirulenta (SP13) y áltamente virulenta (SP1). 
aproximadamente un $20 \%$ más de expresión de ftf1 en el aislado supervirulento que en el altamente virulento. Sin embargo, a diferencia de SP1 donde la expresión de ftf1 empieza a decrecer hasta las 48 horas tras la infección, en SP13 la expresión se estabiliza anteriormente a las 24 horas y a partir de ese momento permanece estable en valores parecidos a los que también alcanza SP1 a los tiempos más largos.

\begin{tabular}{|c|c|c|c|c|c|}
\hline Muestra & $\mathrm{Ct}$ & $\mathrm{dCt}$ & dCt std err & $\mathrm{ddCt}$ & $\mathrm{RQ}$ \\
\hline$\underline{\mathrm{SP} 1-06 \mathrm{~h}}$ & $\underline{19,575}$ & $-1,077$ & $\underline{0,417}$ & $\underline{0,00}$ & $\underline{1,00}$ \\
\hline $\mathrm{SP1}-12 \mathrm{~h}$ & 18,454 & $-1,213$ & 0,251 & $-0,14$ & 1,10 \\
\hline SP1 - $24 h$ & 17,331 & $-1,354$ & 0,451 & $-0,28$ & 1,21 \\
\hline SP1 - $36 \mathrm{~h}$ & 16,820 & $-1,310$ & 0,378 & $-0,23$ & 1,18 \\
\hline SP1 - $48 \mathrm{~h}$ & 16,873 & $-1,988$ & 0,442 & $-0,91$ & 1,88 \\
\hline SP1 - $72 \mathrm{~h}$ & 18,010 & $-1,794$ & 0,672 & $-0,72$ & 1,64 \\
\hline SP1 - $96 \mathrm{~h}$ & 18,783 & $-0,872$ & 0,587 & 0,21 & 0,87 \\
\hline SP13-06 h & 18,745 & 0,227 & 0,337 & 1,30 & 0,41 \\
\hline SP13-12h & 17,708 & $-0,840$ & 0,354 & 0,24 & 0,85 \\
\hline SP13-24h & 19,344 & 0,220 & 0,451 & 1,30 & 0,41 \\
\hline SP13-48h & 16,461 & $-0,451$ & 0,444 & 0,63 & 0,65 \\
\hline SP13-72h & 17,201 & $-0,740$ & 0,432 & 0,34 & 0,79 \\
\hline SP13-96h & 18,082 & 0,124 & 0,238 & 1,20 & 0,43 \\
\hline
\end{tabular}

Tabla 4. 7 - PCR cuantitativa en tiempo real específica para la detección de la expresión del gen ftf1 a distintos tiempos de crecimiento en cultivo líquido tras la inoculación. Los valores subrayados se tomaron como referencia para la normalización. 


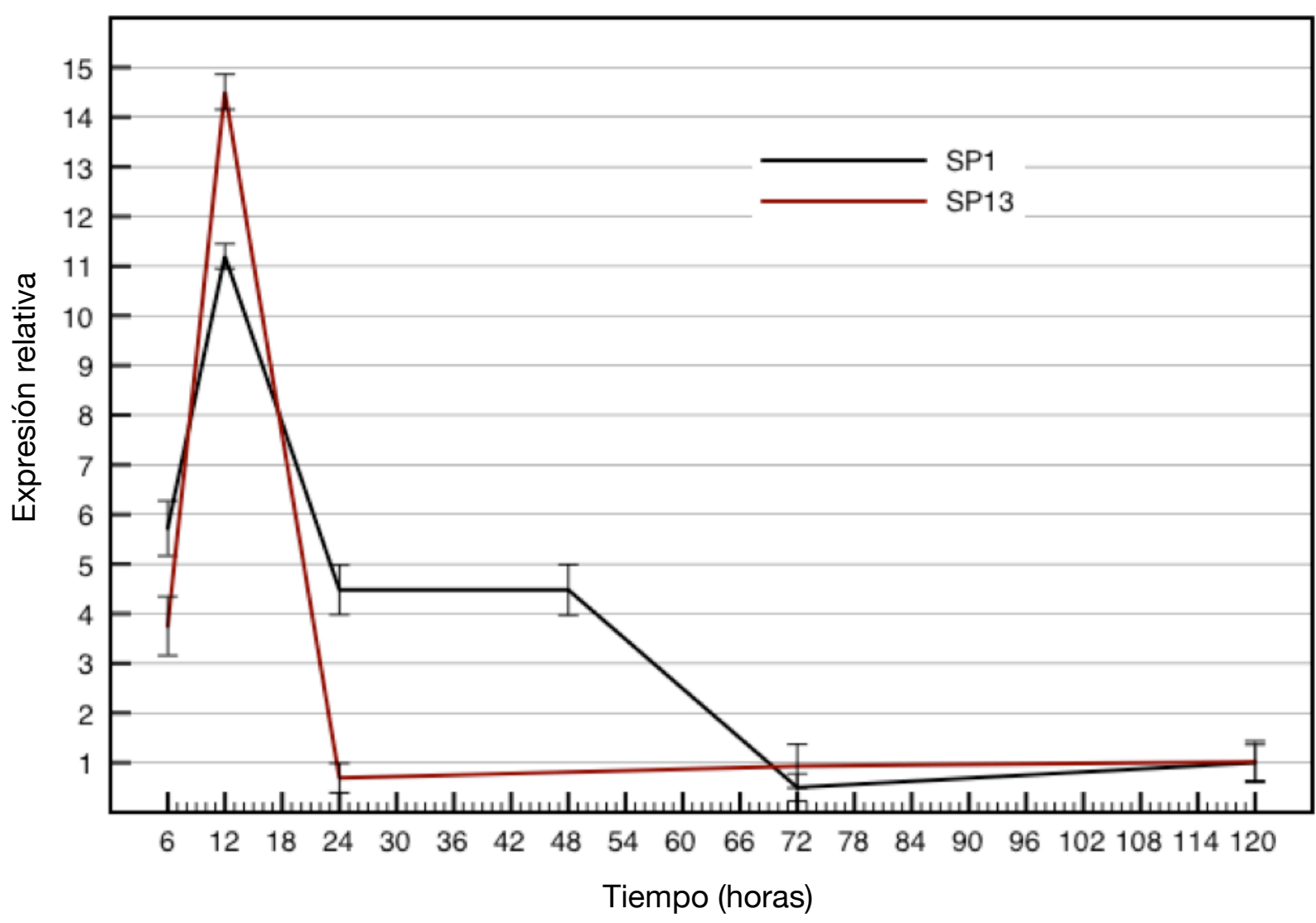

Figura 4. 18 - Expresión relativa del gen ftf1 a lo largo del tiempo (en horas) de crecimiento durante la infección de plantas de judía ( $P$. vulgaris) de una estirpe supervirulenta (SP13) y áltamente virulenta (SP1).

\begin{tabular}{|cc|c|c|c|c|}
\hline Muestra & Ct & dCt & \multicolumn{1}{c|}{ dCt std err } & ddCt & RQ \\
\hline SP1 - 06 hpi & 24,837 & 1,735 & 0,553 & $-2,52$ & 5,72 \\
\hline SP1 - 12 hpi & 25,200 & 0,767 & 0,253 & $-3,49$ & 11,20 \\
\hline SP1 - 24 hpi & 26,130 & 2,090 & 0,498 & $-2,16$ & 4,48 \\
\hline SP1 - 48 hpi & 25,695 & 2,088 & 0,509 & $-2,16$ & 4,48 \\
\hline SP1 - 72 hpi & 26,446 & 5,246 & 0,273 & 0,99 & 0,50 \\
\hline SP1-120 hpi & $\underline{26,568}$ & $\underline{4,252}$ & $\underline{0,364}$ & $\underline{0,00}$ & $\underline{1,00}$ \\
\hline SP13 - 06 hpi & 27,287 & 2,346 & 0,593 & $-1,91$ & 3,75 \\
\hline SP13-12 hpi & 24,214 & 0,393 & 0,355 & $-3,86$ & 14,51 \\
\hline SP13-24 hpi & 29,148 & 4,792 & 0,296 & 0,54 & 0,69 \\
\hline SP13-72 hpi & 27,457 & 4,353 & 0,440 & 0,10 & 0,93 \\
\hline SP13-120 hpi & 26,171 & 4,219 & 0,417 & $-0,03$ & 1,02 \\
\hline
\end{tabular}

Tabla 4. 8 - PCR cuantitativa en tiempo real específica para la detección de la expresión del gen ftf1 a distintos tiempos de crecimiento tras la infección en planta de judía. Los valores subrayados se tomaron como referencia para la normalización. 


\section{3 - Genómica comparada de ftf1 y ftz2 en el género Fusarium}

4.3.1 - fff1 y ftf2 en Fusarium verticilloides,

Fusarium graminearum y Fusarium

oxysporum

\subsubsection{1 - Presencia de ftf1 y ftf2 en el género}

Fusarium y en otros hongos filamentosos

El Broad Institute (MIT, EE.UU.) está realizando la secuenciación y genómica comparativa de tres especies del genero Fusarium: F. verticilliodes, F. graminearum y F. oxysporum. El genoma de F. graminearum (G. zeae) fue el primero en ser secuenciado y ftf1 y ftf2 ya habían sido comparados en el mismo en estudios previos (Ramos, 2005). Pretendemos ampliar el estudio de ftf1 y ftf2 en los nuevos genomas disponibles, especialmente, en $F$. oxysporum.

En este trabajo, se usaron las secuencias de los genes ftf1 y ftf2 obtenidas manualmente en $F$. oxysporum f.sp. phaseoli como patrón de búsqueda en los nuevos genomas secuenciados. La búsqueda con la secuencia conocida de ftf2 localiza una única copia en cada uno de los tres genomas de Fusarium sp. disponibles. No así en $F$. oxysporum como se verá en el apartado 4.3.2.

Se construyó un árbol filogenético de las secuencias homólogas en los genomas de las tres especies (Figura 4. 28 - Pág. 104). Como se observa en el mismo, las secuencias homólogas a ftf2 en $F$. oxysporum y $F$. verticilloides son más parecidas entre si, que el resto de copias homólogas de $F$. oxysporum entre si. La única secuencia homóloga de $F$. graminearum, que se corresponde con ftf2, presenta más homología con las copias de ftf1 en $F$. oxysporum f.sp. lycopersici, que a las secuencias de ftf2, lo que de idea de la semejanza de las secuencias de ftf1 y ftf2.

En trabajos anteriores, una búsqueda más amplia permitió localizar genes homólogos a ftf2, también presentes como copia única, en los genomas de algunos hongos patógenos (como Magnaporthe grisea y Aspergillus niger) y no patógenos (como Neurospora crassa y Podosposa anserina).

En el estudio de las regiones flanqueantes de ftf2 (Figura 4. 20 - Pág. 97) en los tres genomas de Fusarium sp. observamos que los genes cercanos están conservados evolutivamente. Aguas arriba, existen una Peptidasa de la familia C50 y una Histona de la familia Sir2. En las $5 \mathrm{kbp}$ aguas abajo, se conservan tres genes hipotéticos: un gen homólogo a Krr1 implicado en el ensamblaje de ribosomas, un gen homólogo a activadores GTPasa mitocondriales y un gen $\sin$ dominios identificables. Por el contrario, en Magnaporthe grisea el tercero de estos genes presentes aguas abajo no existe y los otros dos están más distanciados 
de ftf2. Más aún, en Neurospora crassa y Aspergillus nidulans las regiones flanqueantes en ambos sentidos no se encuentran conservadas.

En la Figura 4. 18 (Pág. 94) de secuencias homólogas a ftf2, comprobamos que ftf2 está presente en varios hongos filamentos, todos ellos ascomicetos. El dendrograma de semejanzas se divide en dos grupos. El grupo en el que se encuentra $F$. oxysporum alberga otros hongos de la misma familia de sordariomicetos. Las especies se distribuyen según su relación evolutiva (por géneros y familias), y no por su forma de vida o patogenicidad. El otro grupo engloba otros ascomicetos no piromicetos, destacando el agrupamiento de varias especies del genero Aspergilus $s p$. en las que $f t f 2$ presenta una gran homología.

\subsubsection{2 - Polimorfismos del gen ftf1 en diferentes} formas especiales de $F$. oxysporum

Con el objetivo de profundizar en el conocimiento de ftf1 en la especie Fusarium oxysporum, se secuenció un fragmento de aproximadamente $500 \mathrm{bp}$ del comienzo del gen ftf1 en varias formas especiales de la misma, usando los oligonucleótidos B5 y M17A específicos para una sola de las copias (la denominada ftf1a en F. oxysporum f.sp. phaseoli).

Se seleccionó un aislado perteneciente a cada una de las formas especiales presentes en nuestra colección. Como F. oxysporum f.sp. lycopersici es la forma especial secuenciada por el Broad Institute, se incluyeron siete aislados de la misma en las hibridaciones Southern. Como

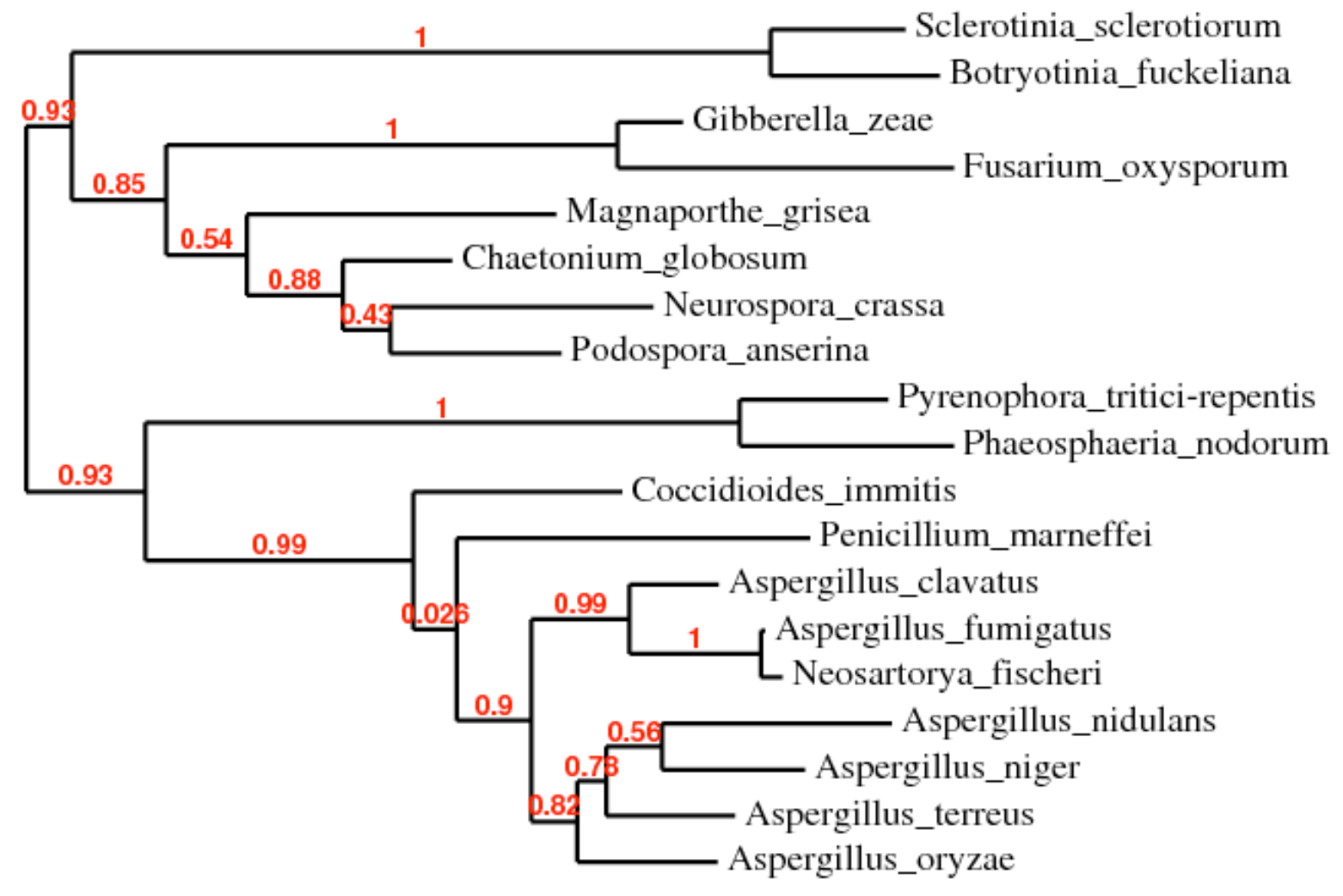

0.4

Figura 4. 19 - Dendrograma de semejanzas de secuencias homólogas a ftf2 en varias especies de hongos. 
referencia también se incluyeron siete aislados de la forma especial nicotiana.

La variación de ftf1a es mínima entre las distintas formas especiales, y el alineamiento múltiple tiene una homología del 95\%. En el dendrograma de semejanzas (Figura 4. 21 - Pág. 98) resultante se aprecia que la región secuenciada presenta homologías máximas para las estirpes pertenecientes a la misma forma especial, excepto en el caso de la estirpe 17131 de la forma especial pini. En la Figura 4. 22 (Pág. 99) se observa que existen cambios en nucleótidos concretos, cambios que son específicos para cada forma especial.
4.3.1.3 - Número de copias de ftf1 en diferentes formas especiales de F. oxysporum

Con el fin de realizar una estimación del grado de polimorfismo existente en las copias de ftf1 presentes en aislados de distintas formas especiales, se realizaron análisis mediante hibridaciones Southern usando sondas previamente usadas en la caracterización de este gen en la forma especial phaseoli y el ADN de los aislados digerido con la enzima de restricción HindIIl.

Con la sonda B310-A280 (que hibrida en la región promotora) (Figura 4. 24 - Pág. 100) se aprecia que el número de bandas varía de unas formas especiales a otras. La mayor parte de las formas especiales
Cr. 9 Supercont. 11

F. graminearum

Cr. 3 Supercont. 3

F. verticillioides

Cr. 7 Supercont. 8

Magnaporthe grisea Cr. 5 Supercont. 190

Neurospora crassa Cr. 3 Contig. 27

Aspergillus nidulans

Cr. 2 Contig. 67
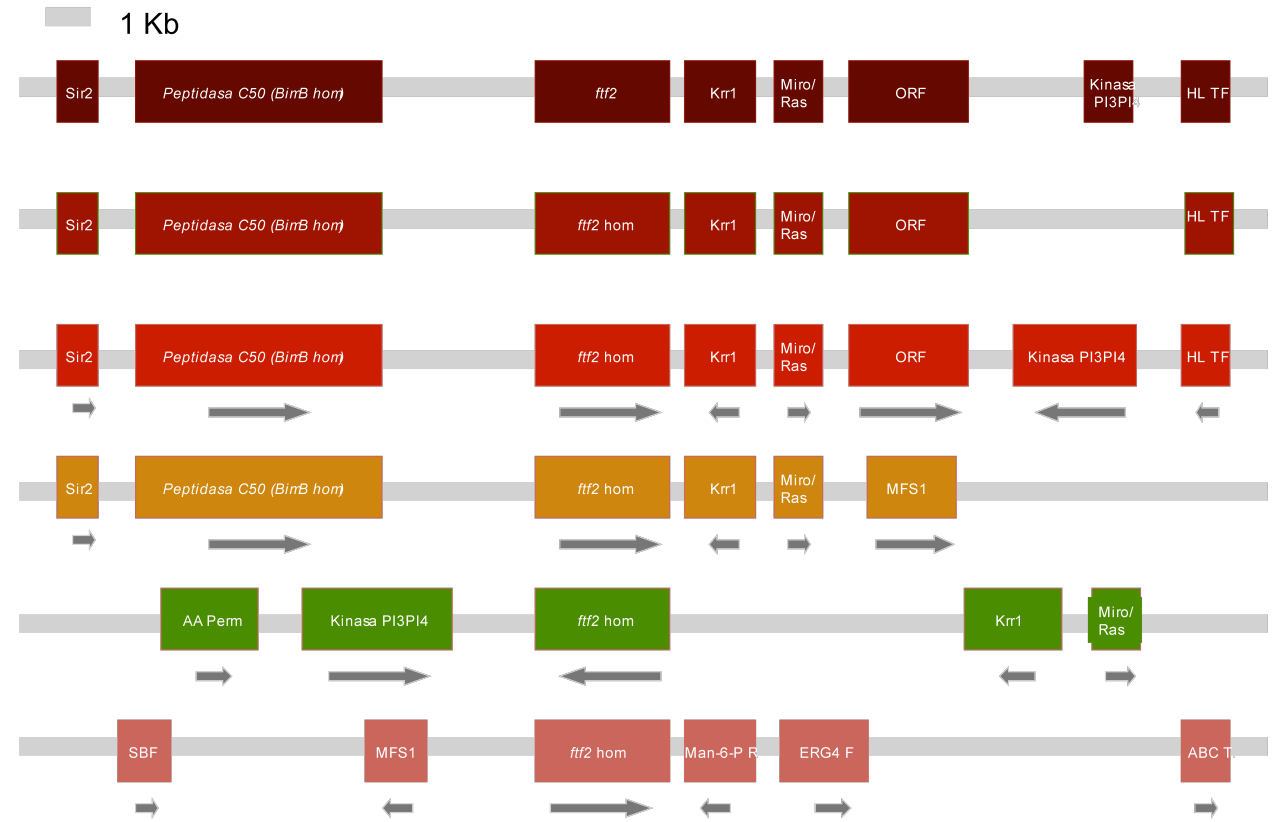

Figura 4. 20 - ORFs situadas en las regiones flanqueantes al gen ftf2 en varias especies de hongos. Sir2: desacetilasa de histonas de la familia Sir2; Peptidasa C50: peptidasa de la familia C50 (homóloga del producto génico de BimB de $A$. nidulans); Krr1: implicado en el ensamblaje de ribosomas; Miro/Ras: Rho GTPasa mitocondrial/ activador tipo Ras de GTPasa; Kinasa PI3PI4: fosfatidil inositol 3,4 kinasa (la secuencia presente en $F$. oxysporum sólo es parcialmente homóloga; en $F$. graminearum no se encuentra); HL TF: factor de transcripción tipo histona; MFS1: transportador de la superfamilia MFS; ABC T: transportador de la superfamilia $A B C$; AA Perm: permeasa de aminoácidos; SBF: transportador transmembranal de la familia sodio-ácido bílico; Man-6-P R; receptor de manosa-6-fosfato; ERG4 F: familia de biosíntesis de ergosterol Las flechas indican las direcciones de transcripción. 
presenta un número teórico de copias polimórficas de entre tres y seis. Algunas formas especiales destacan por tener un número mayor de copias, como el caso de las formas especiales raphani con diez señales, y el aislado 36283 (no así el aislado 26050) de la forma especial pisi, con nueve señales.

En varias formas especiales se ha estudiado más de un aislado. Mientras que todos los aislados de la forma especial nicotiana presentaban tres bandas, en las formas especiales lycopersici y pini se observan tres configuraciones distintas en cada una de ellas.

En el caso de la forma especial pini, en cinco de los aislados (Fo1, Fo4P, Fo5P,
Fo6P y 17131) solo se aprecia una banda, característica que solo se repite en el aislado de la forma especial melonis. La existencia de una única banda se ha observado en Southerns de aislados débilmente virulentos como SP4 (ej. carrill 9 de la Figura 4. 13 Pág. 85) y se corresponde con fragmentos del gen ftf2. En el caso de los aislados de la f.sp pini esta única banda se sitúa en tamaños diferentes, lo que parece indicar que se trata de distintas copias polimórficas. Más aún, uno de los aislados de la f.sp. pini (Fo2) presenta dos señales, bien por la existencia en la región B310-A280 de un sitio interno HindIII con el que se digirió el ADN para preparar la membrana, bien por tratarse de una copia de ftf1.

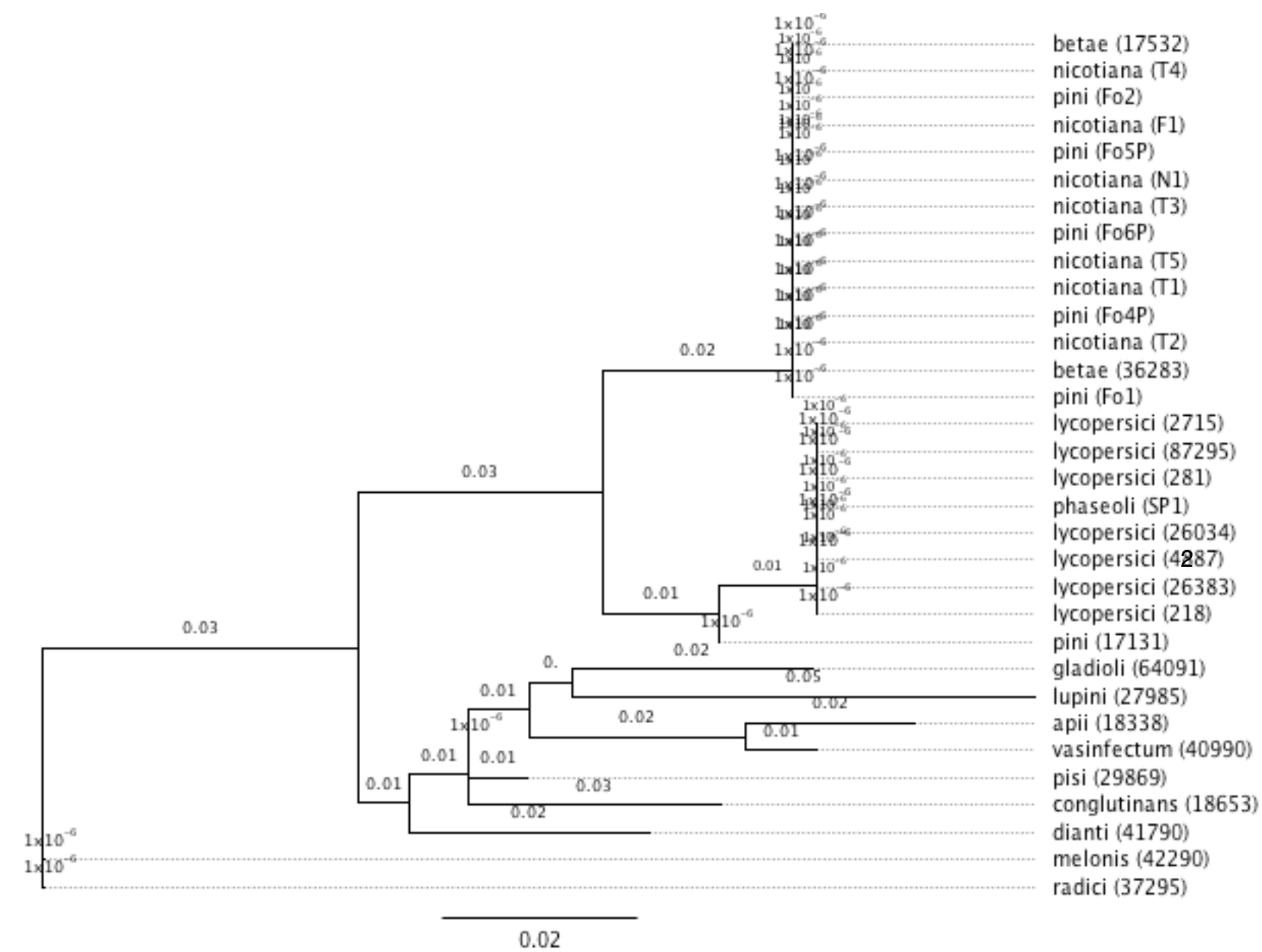

Figura 4. 21 - Dendrograma de semejanzas del fragmento B5-M17A de la región codificante homóloga a ftf1a, clonada y secuenciado en aislados de diferentes formas especiales de $F$. oxysporum 
Cuatro de los aislados (26034, 26383, 2715 y 87295$)$ muestran cinco bandas. El aislado 218 muestra seis bandas, cuatro de ellas son comunes a los anteriores, pero una de las bandas ha desaparecido, apareciendo en su lugar dos nuevas bandas, lo que sustenta la existencia de un poliformismo del sitio HindIII en esa región.

Un caso diferente es el de los aislados 4287 y 281 , iguales entre si, y que presentan seis copias teóricas: las cinco bandas comunes a los cuatro aislados anteriores, y una sexta banda adicional.

Como segunda sonda, se uso M18BM19A (Figura 4. 23 - Pág. 100), que se obtuvo amplificando una región del segundo exón de ftf1a de entorno a 0,5 kbp.

En los aislados que se detectó una única señal con el sonda de la región promotora, la correspondencia en el número de señales obtenidas en esta segunda hibridación, confirmó el número de copias propuesto, una única copia para los aislados Fo1, Fo4P, Fo5P, Fo6P y 26050 de la forma especial pini; y dos copias en el aislado Fo2 de la forma especial pini y el único aislado estudiado de la forma especial melonis.

Los aislados de la forma especial nicotania muestran solo dos señales, una menos que usando la sonda del promotor. La excepción es el aislado T5, que muestra tres señales: las dos comunes al resto y una
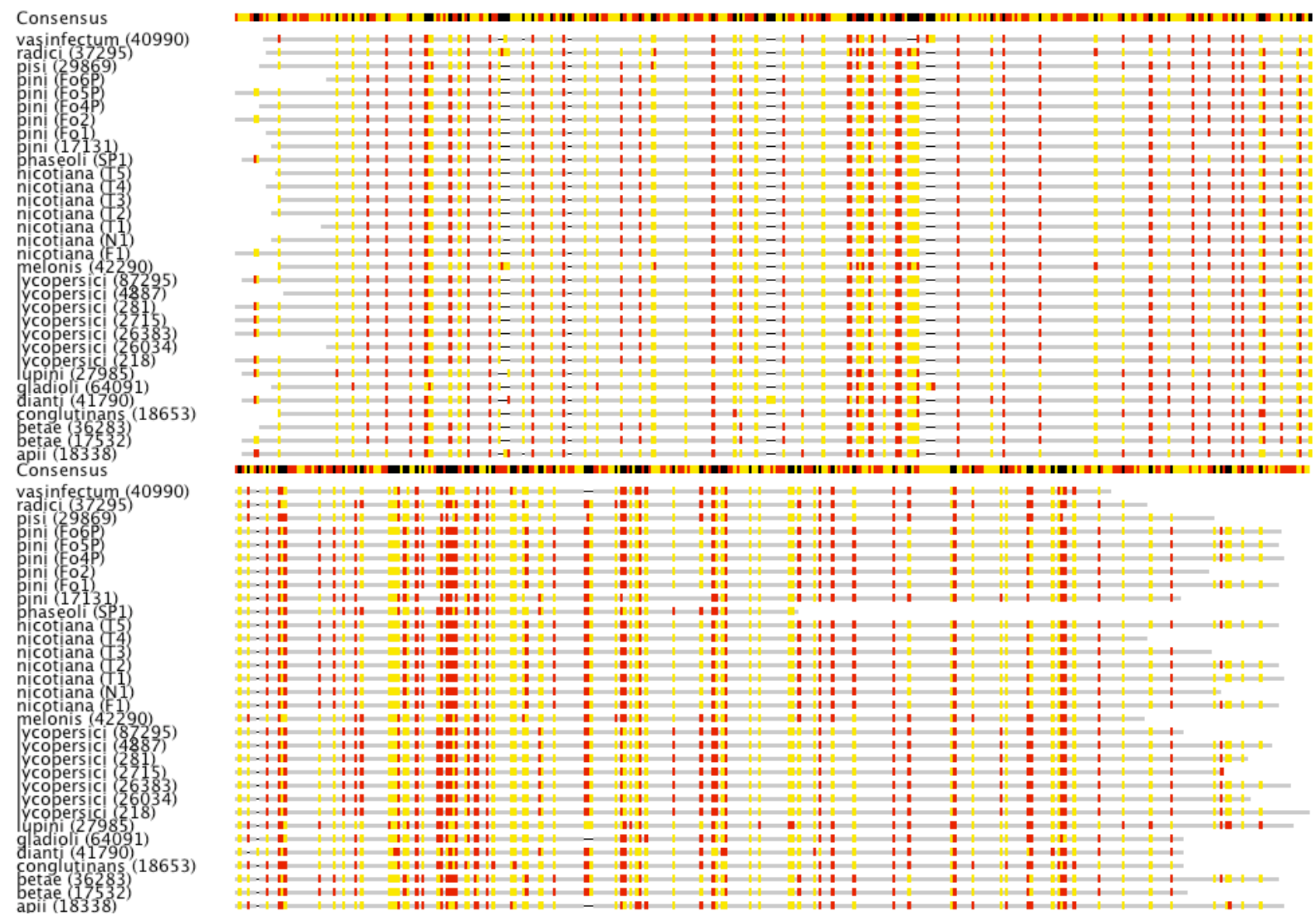

Figura 4. 22 - Alineamiento del fragmento B5-M17A de las secuencias nucleotídicas de ftf1 en varias formas especiales de $F$. oxysporum. Las anotaciones de colores representan nucleótidos de adenina y timina (rojo), o guanina y citosina (amarillo). 
adicional.

En el caso de los aislados de la forma especial lycopersici, los aislados se dividen en cinco perfiles distintos. Los aislados 218 y 26034 presentan seis bandas, aunque no está claro en el caso del segundo. El aislado 26383 también tiene 6 bandas pero el perfil es distinto a los anteriores. Los aislados
87295 y 2715 tienen 5 bandas. Finalmente, los aislados 4287 y 281 muestran 7 señales, una más que el resto, confirmando los resultados anteriores.

El genoma del aislado 4287 de $F$. oxysporum f.sp. lycopersici ha sido secuenciado, por lo que se puede hacer una relación con los resultados de los Southerns.

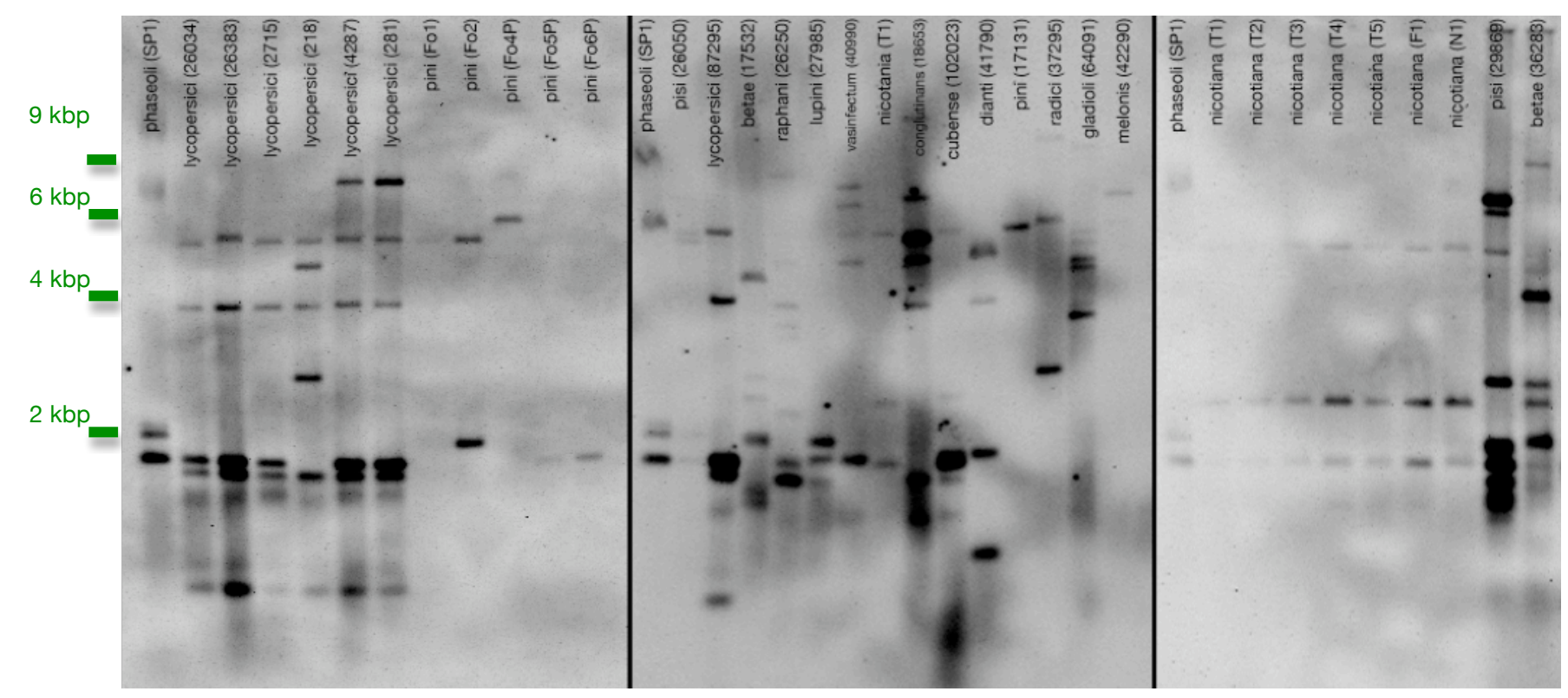

Figura 4. 24 - Hibridación tipo Southern con la sonda del promotor B310-A280 de ADN digerido con HindlII de aislados de F. oxysporum pertenecientes a diferentes formas especiales. Se indica la forma especial y entre paréntesis el aislado.

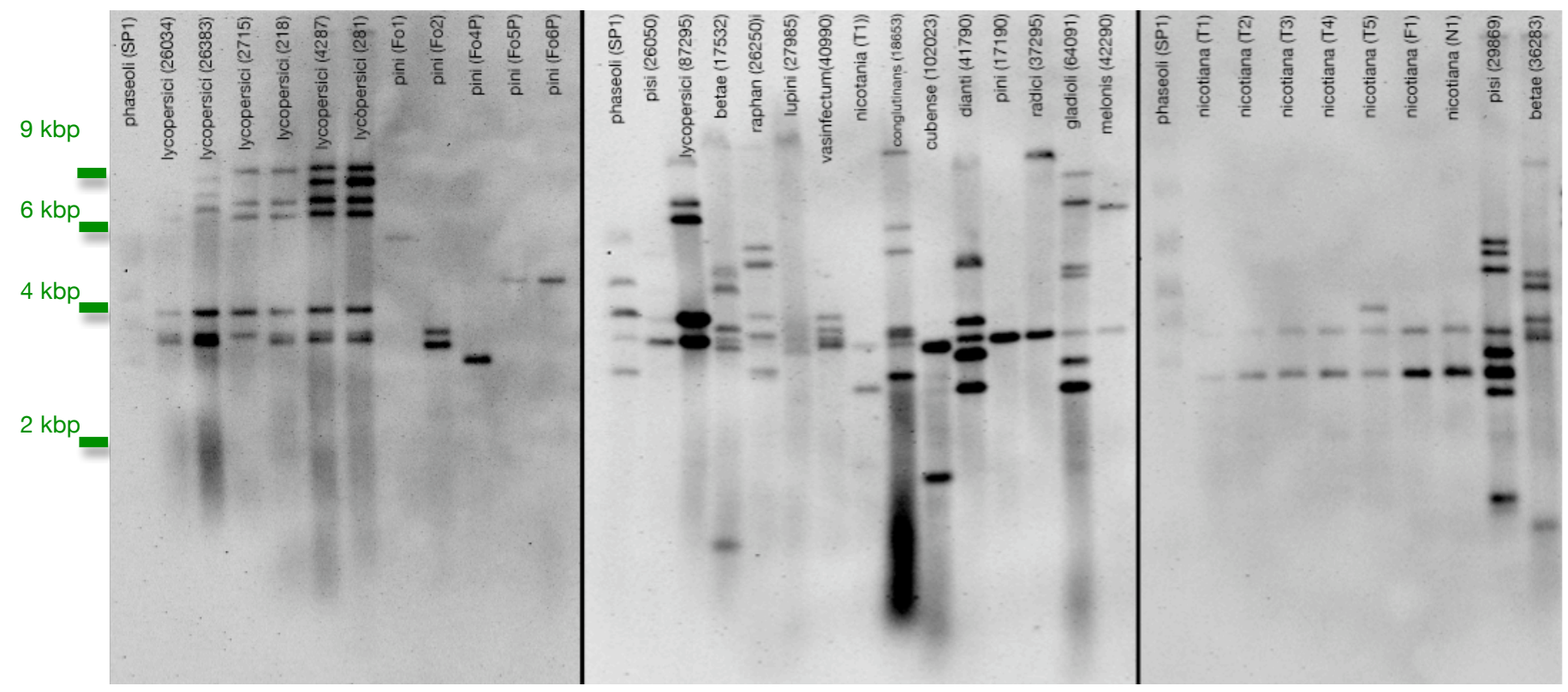

Figura 4. 23 - Hibridación tipo Southern con la sonda de la región codificante M18B-M19A de ADN digerido con HindIII de aislados de F. oxysporum pertenecientes a diferentes formas especiales. Se indica la forma especial y entre paréntesis el aislado. 
En la Figura 4. 25 (Pág. 100), se representan las copias de ftf1 en el aislado secuenciado, con la situación de las sondas y los sitios de restricción HindIII de las mismas. La mayor parte de las copias tienen un sitio HindIII pocos nucleótidos antes de la región de hibridación de M18B-M19A. El tamaño de la banda que engloba el sitio de hibridación de la sonda M18B-M19A es visible en tres de ellos. El fragmento de la copia 01 mide 4,1 $\mathrm{Kb}$, el de la copia 04 mide 3,6 Kb. y el de la copia 05 mide 3,5 Kb. Estos dos últimos son prácticamente indistinguibles en el Southern y se corresponden con la doble banda de menor tamaño que aparece en todos los aislados menos 2715, que no tiene la copia $05(3,5 \mathrm{~Kb})$. Se verifica además la correspondencia en $04(3,6 \mathrm{~Kb})$ y ftf2 pues esta banda esta presente en todos los aislados. Las copias 07, 08, 09 y 10 son iguales en una amplia región mayor. Las cuatro tienen un sitio HindIII aguas abajo del fragmento mostrado en la gráfica, separado 7,2 Kb. del sitio HindIII común a casi todas las copias. Las copias 02 y 03 también son iguales en una amplia región. Estas copias no conservan el sitio HindIII presente en el resto de copias pero si lo tienen en el terminador del gen. Aguas arriba del gen ftf1 tienen otro sitio que da lugar a un fragmento polimórfico de $8,96 \mathrm{~Kb}$. Algo parecido sucede con la copia 06 , solo que en este caso el fragmento tiene una longitud de 10,5 Kb. La banda del Southern restante se corresponde con la

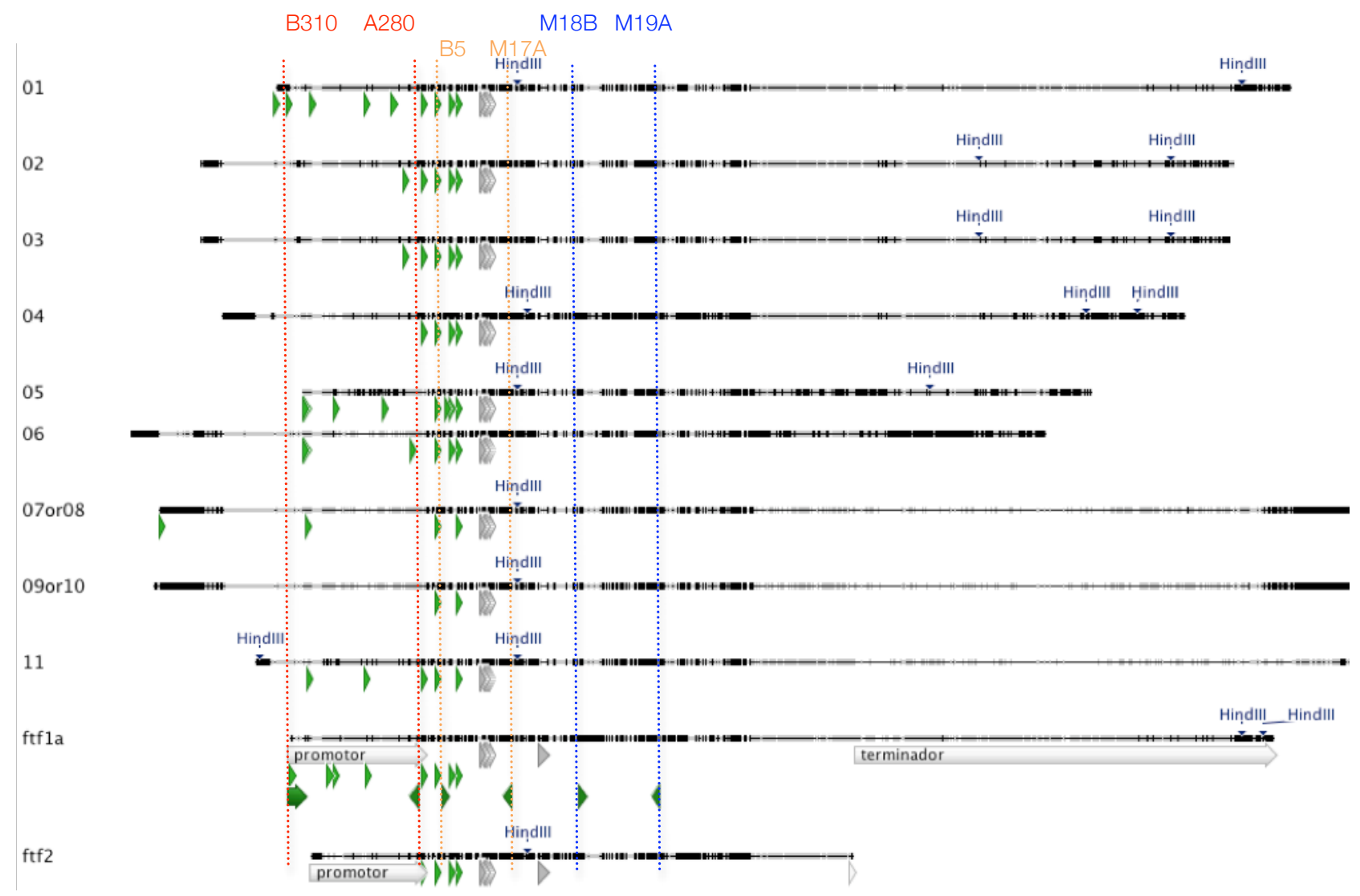

Figura 4. 25 - Sitios HindIII en ftf1a y ftf2 de F. oxysporum f.sp. phaseoli y las distintas copias de ftf1 en $F$. oxysporum f.sp. lycopersici. Triángulos grís oscuro: cisteinas del dominio dedo de zinc $\mathrm{Zn}(\mathrm{II})_{2} \mathrm{Cys}_{6}$. Triángulos verde: codones de inicio de la traducción. Flecha verde: oligonucleótido. 
copia 11, que da lugar a un fragmento de 11 Kb. La predicción de estas cuatro bandas de 7,2; 8,96; 10,5 y $11 \mathrm{~Kb}$ concuerda con los resultados del Southern y las 4 bandas que se observan en la parte superior de los carriles de los aislados 4287 y 281.

\subsection{2 - ftf1 y ftf2 en Fusarium oxysporum f.sp.} Iycopersici

\subsubsection{1 - Secuencias similares a ftf1 y ftf2 en}

Fusarium oxysporum f.sp. Iycopersici

Como se ha comentado, se realizó una búsqueda en el genoma secuenciado de F. oxysporum (f.sp. lycopersici estirpe 4287, perteneciente a la raza 2 y VCG 0030) mediante un alineamiento BLAST usando como sonda la secuencia nucleotídica (5.313 bp) de la copia de ftf1 (que denominamos

supercontig 24

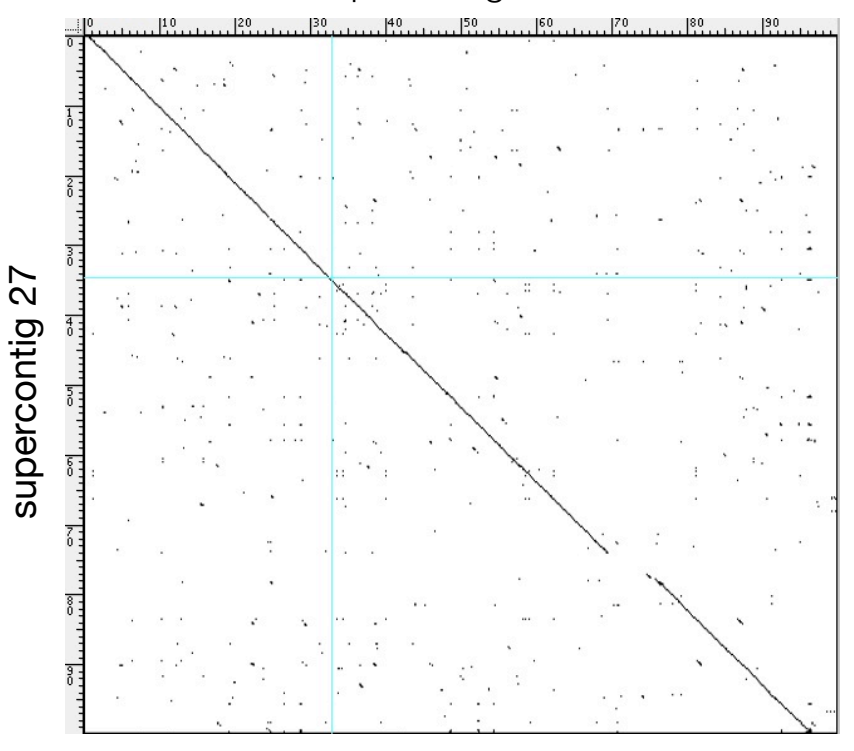

Figura 4. 27 - Matriz de puntos (dotplot) de similitud entre el supercontig 24 (eje horizontal) $y$ el supercontig 27 (eje vertical). ftf1a) de $F$. oxysporum f.sp. phaseoli depositada en GenBank (DQ280313), obteniendo como resultado 11 secuencias con diferencias estadísticamente significativas (Tabla 4. 9 - Pág. 103).

Con el objetivo de aumentar el posible rango de secuencias homólogas se realizó una segunda búsqueda usando como sonda solo la región codificante de ftf1a (3.296bp). No se obtuvieron nuevas secuencias susceptibles de ser copias de ftf1 o ftf2.

Se ha construido un árbol filogenético (Figura 4. 28) de las secuencias descargadas a partir de un alineamiento múltiple, con el objetivo de conocer la relación entre las distintas copias de $F$. oxysporum f.sp. lycopersici y de estas con las de la forma especial phaseoli conocidas. La copia 01 de la forma especial lycopersici es igual a la copias ftf1a (f.sp. phaseoli), y de igual manera

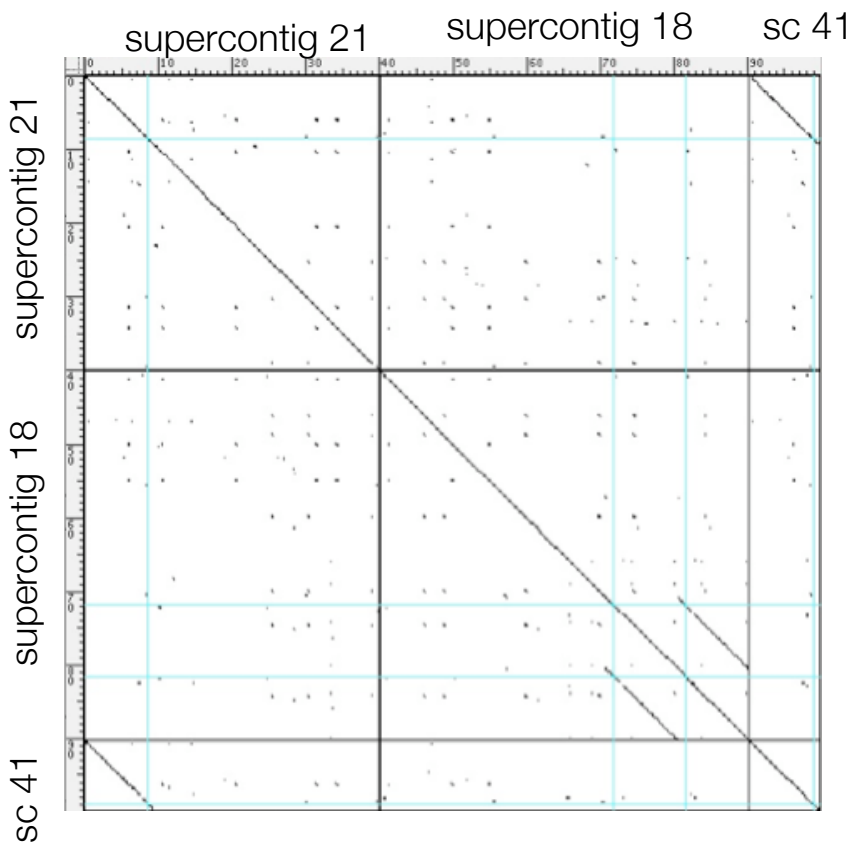

Figura 4. 26 - Matriz de puntos (dotplot) de similitud entre los supercontig (de izq. a der.): 21 (1.072 kbp), 18 (1.345 kbp) y 41 (257 kbp); y de arriba abajo en el mismo orden. 
sucede entre ftf2 y la copia 04.

4.3.2.2 - Número de copias en el genoma de $\boldsymbol{F}$. oxysporum f.sp. lycopersici

Por un lado, en las hibridaciones Southern de varias formas especiales de $F$. oxysporum (Figura 4. 23 Figura 4. 24 - Pág. 100), en el caso concreto de la forma especial lycopersici se observa que el número señales distintas homólogas al promotor de ftf1a (forma especial phaseoli) está entre 5 y 6, dependiendo del aislado. Y cuando se usa una sonda de la región codificante (también construida a partir de ftf1a) como M18BM19A, el número de señales distintas homólogas a ftf1a es también de 5 a 6 .

Por otro lado, los resultados de los alineamientos realizados en el apartado anterior de algunas de las secuencias, presentaban valores coincidentes que sugerían que podía tratarse de secuencias

\begin{tabular}{|c|c|c|c|c|c|c|c|c|}
\hline & & & \multicolumn{2}{|c|}{$\begin{array}{l}\text { completo } \\
\text { (5.313 bp) }\end{array}$} & \multicolumn{2}{|c|}{$\begin{array}{c}\text { Región codificante (3.296 } \\
\text { bp) }\end{array}$} & \multicolumn{2}{|c|}{$\begin{array}{l}\text { Promotor } \\
\text { (670 bp) }\end{array}$} \\
\hline ID & SC & CR & $\begin{array}{l}\text { Identid. } \\
\% \text { (nt) }\end{array}$ & $\begin{array}{l}\text { Long. } \\
\text { homolog } \\
\text { (nt) }\end{array}$ & $\begin{array}{l}\text { Identid. } \\
\% \text { (nt) }\end{array}$ & $\begin{array}{l}\text { Long. } \\
\text { homolog. } \\
\text { (nt) }\end{array}$ & $\begin{array}{l}\text { Identid. } \\
\% \text { (nt) }\end{array}$ & $\begin{array}{l}\text { Long. } \\
\text { homolog. } \\
\text { (nt) }\end{array}$ \\
\hline 01 & 22 & 14 & 97,8 (5199) & 5315 & 97,8 (3223) & 3296 & 99,9 (669) & 670 \\
\hline 02 & 27 & 1 & $91,0(3355)$ & 3688 & $91,6(3025)$ & 3303 & 86,1 (297) & 345 \\
\hline 03 & 24 & 15 & 91,0 (3355) & 3688 & 91,6 (3025) & 3303 & 86,1 (297) & 345 \\
\hline 04 & 51 & 14 & 90,7 (3400) & 3750 & 91,3 (3002) & 3287 & $86,4(414)$ & 479 \\
\hline 05 & 42 & 6 & 92,1 (2724) & 2958 & 92,1 (2724) & 2958 & 33 & 35 \\
\hline 06 & 36 & 14 & 90,9 (2685) & 2954 & 90,9 (2685) & 2954 & 0 & 0 \\
\hline 07 & 21 & 6 & 91,3 (2372) & 2599 & 91,3 (2373) & 2599 & 34 & 34 \\
\hline 08 & 41 & 6 & $91,3(2372)$ & 2597 & 91,3 (2372) & 2597 & 34 & 34 \\
\hline 09 & 18 & 3 & 91,3 (2372) & 2597 & 91,3 (2372) & 2597 & 34 & 34 \\
\hline 10 & 18 & 3 & $91,3(2372)$ & 2597 & 91,3 (2372) & 2597 & 34 & 34 \\
\hline 11 & 11 & 9 & 84,6 (713) & 843 & 84,6 (713) & 843 & 85 & 102 \\
\hline
\end{tabular}

Tabla 4. 9 - Homologías observada entre las distintas regiones del genoma de $F$. oxysporum f.sp. lycopersici (presuntas copias de ftf1) y la copia ftf1a de F. oxyporum f.sp. phaseoli, según se use en la comparación la secuencia completa, la región codificante o la región promotora. ID: Número asignado para la identificación de la copia. SC: Supercontig. CR: Cromosoma. Identid.: Número de identidades totales. Long Homolog.: Longitud total de la región homóloga. 
iguales, bien fruto de un artificio de la secuenciación masiva, bien consecuencia de procesos naturales de duplicación. El alineamiento de las diferentes secuencias (promotor y región codificante) (Tabla 4. 10 Pág. 105) dio aún más peso a esta hipótesis.

Las secuencias completas de los supercontigs ensamblados por el proyecto de secuenciación de $F$. oxysporum f.sp. lycopersici se usaron para obtener una matriz de puntos de homología entre secuencias del tipo dotplot, por la que se disponen las secuencias nucleotídicas a lo largo de los ejes, dibujándose un punto allí donde exista una similitud de bases de longitud igual al tamaño de ventana configurado.

Se compararon los supercontigs 24 y 27 (que contienen las copias denominadas 03 y 02 , respectivamente), usando la herramienta dottup. Así mismo, se compararon los supercontigs 18, 21 y 41 (que respectivamente contienen las copias 08 y 09 -ambas en el supercontig 18-, 10 y 07) usando el programa polydot. Ambos programas pertenecen al paquete EMBOSS y se configuraron con una ventana de 25

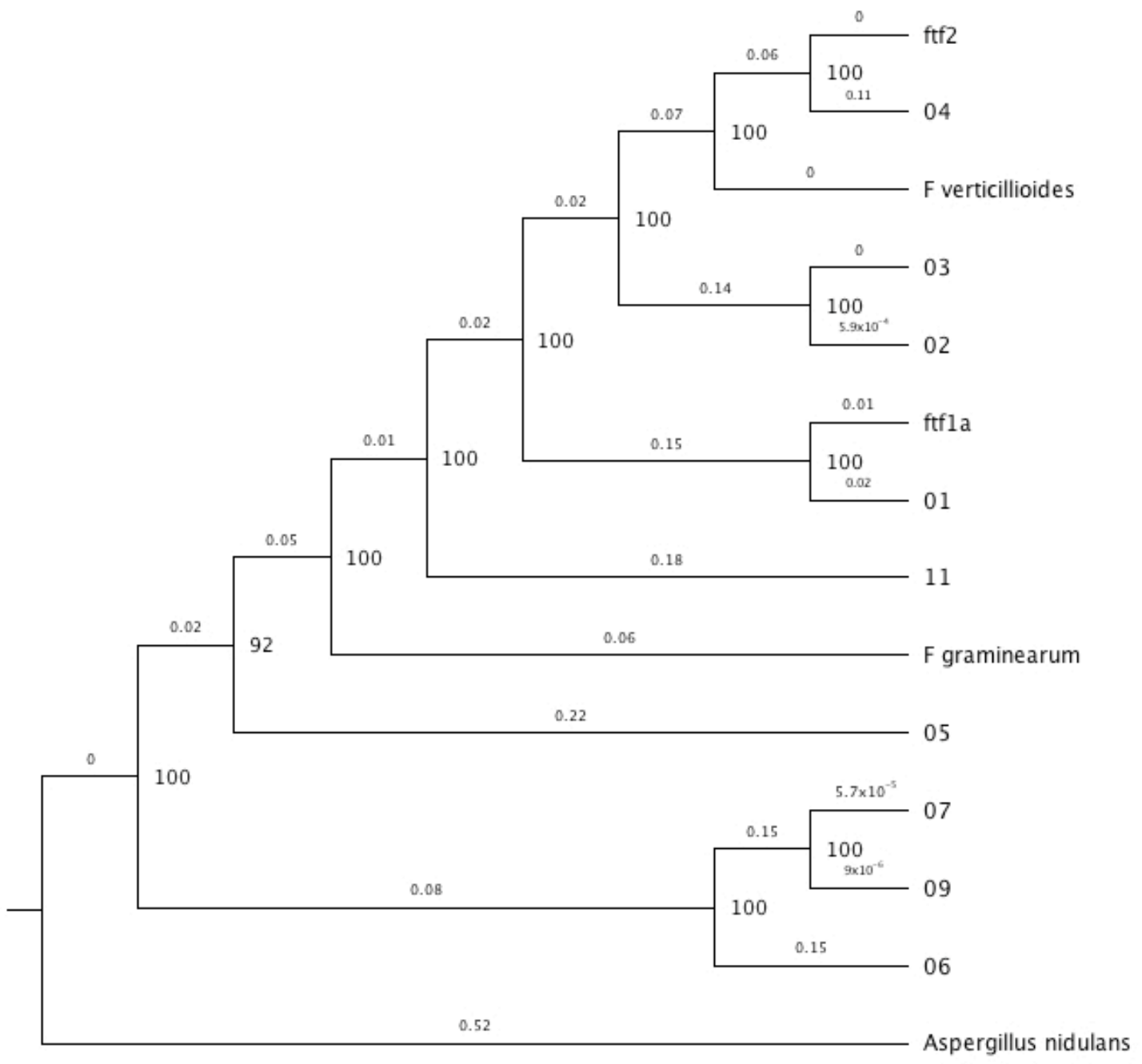

Figura 4. 28 - Árbol filogenético de la relación de las secuencias homologas ftf2 en las especies secuenciadas del género Fusarium, asi como la relación entre las copias homólogas a ftf1 de F. oxysporum f.sp. lycopersici y f.sp. phaseoli. F. verticilloides: ftf2 en Fv. F. graminearum: ftf2 en Fg. Numeradas 01-12: Secuencias homólogas en F. oxysporum $f$. sp. lycopersici. Ftf1a y ftf2: Copias conocidad de ftf1 y ftf2 en F. oxysporum f.sp. phaseoli. Aspergillus nidulans: ftf2 en A. nidulans. 
nucleótidos.

En la Figura 4. 27 (Pág. 102) el supercontig 24, que tiene $957.384 \mathrm{bp}$, se dispone en el eje de abcisas, y la copia homologa a ftf1a comenzaría en el nucleótido 643.449 respecto al comienzo de este supercontig. Si consideramos la longitud total como el valor $100 \%$ y dado que a efectos de que sea más fácil observar el patrón el supercontig 24 se ha dispuesto en sentido inverso o antisentido, la copia del gen de interés se corresponde con el valor de $32,8 \%$. Por otro lado, la copia homologa a ftf1a del supercontig 27 (eje de ordenadas) empieza en el nucleótido 307.348 de un total de 891.037, lo que se corresponde con un valor de $34,5 \%$. Ambos puntos se representan con una línea azul.

Existe una correspondencia prácticamente absoluta entre las dos secuencias excepto en la esquina inferior derecha ya que el supercontig 24 tiene una longitud mayor que el supercontig 27. La disposición de las copias a lo largo de sus respectivos supercontigs es prácticamente equivalente y al no observarse otros puntos en la misma recta, lo que sería muestra de regiones homólogas, no existen terceros fragmentos de 25 nucleótidos (tamaño de las ventana usado con el programa dottup) iguales a los dos estudiados.

En el otro caso, usando el programa polidot se construyó una gráfica común para los supercontigs 18, 21 y 41 . En la Figura 4. 26 (Pág. 102), se verifica la existencia de una correspondencia lógica de cada supercontig consigo mismo representado por una línea de puntos a lo largo de toda la diagonal de la gráfica.

Además, se observan otras dos líneas de puntos en la gráfica: La primera abarca toda la longitud del supercontig $41(257.555$

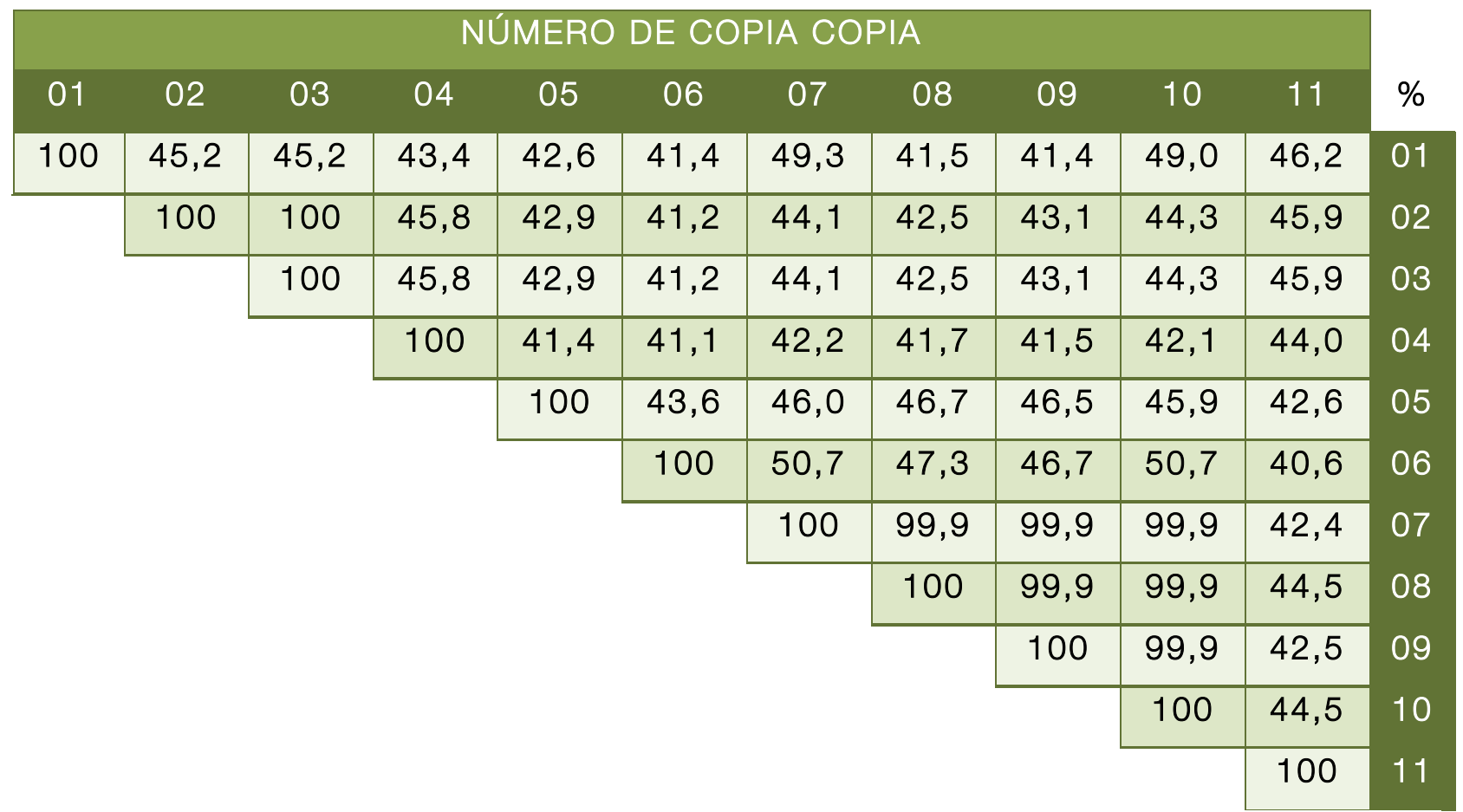

Tabla 4. 10 - Homología entre las copias de ftf1 y ftf2 en F. oxysporum f.sp. lycopersicy. En cada celda el porcentaje de similitud entre el respectivo par de secuencias completas (promotor y región codificante). 
bp) que es completamente igual al comienzo del supercontig $21 \quad$ (1.072.427 bp). La segunda enfrenta el supercontig 18 consigo mismo, lo que indica que la parte final de este supercontig (unas $250 \mathrm{kbp}$ ) es homóloga a la que inmediatamente la precede, lo que sugiere que el supercontig 18 tiene una longitud real menor que la presupuesta o ha sufrido un proceso reciente de duplicación, y en consecuencia presenta una copia adicional de ftf1.

Por lo anterior, de las 11 secuencias que presentaban homología con ftf1a, aparentemente solo 8 son reales. Sin embargo, como las copias 02 y 03 se han marcado como pertenecientes a distintos cromosomas se ha preferido seguir considerándolas como independientes. No así con las copias que han sido anotadas como pertenecientes al mismo cromosoma (la 07 con la 08, y la 09 con la 10) y por tanto identificables como errores de secuenciación.

\subsubsection{3 - Análisis de las secuencias del promotor}

La máxima divergencia entre las secuencias nucleotídicas de las distintas copias se vió en la parte del promotor del gen. Con el objeto de profundizar en su conocimiento se realizó un análisis del alineamiento de las mismas (Figura 4. 32 Pág. 111).

El grado de homología de los $670 \mathrm{nt}$ del promotor anteriores al codon ATG de

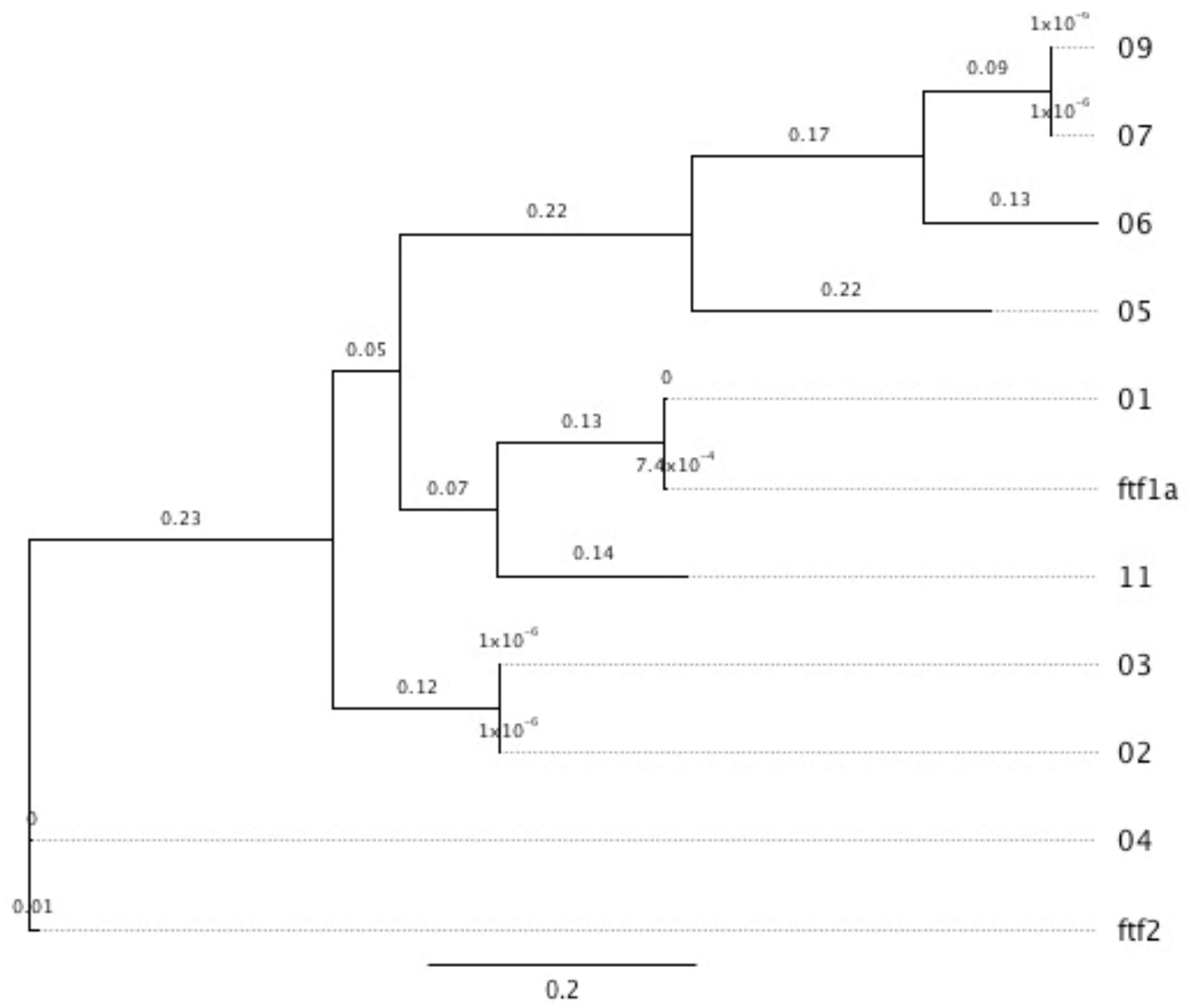

Figura 4. 29 - Dendrograma de semejanzas entre las secuencias del promotor de los genes ftf1 y ftf2 en las formas especiales lycopersici (Numeradas 01 a 11) y phaseoli (nombradas ftf1a y ftf2). 
inicio, entre las copias del gen ftf1 en $F$. oxysporum f.sp. lycopersici y la copia perteneciente a la f.sp. phaseoli (que se ha secuenciado manualmente) es muy variable: como se registra en la Tabla 4. 9 (Pág. 103), mientras una de las copias presentó una identidad completa, otras copias apenas presentan similitud y por tanto, cuentan con promotores que son diferentes al caracterizado en F. oxysporum f.sp. phaseoli.

Como se aprecia en la Figura 4. 32 (Pág. 111), se buscaron motivos conservados tipo TATA (triángulos grises) y CAAT (pequeñas flechas amarillas), así como tripletes de nucleótidos que codificasen codones de inicio de la transcripción (triángulos verdes).

Cada una de las copias estudiadas se usó como secuencia problema en alineamientos tipo BLASTN frente a las bases de datos del $\mathrm{NBCl}$, y los resultados relevantes también se anotaron.

Es relevante la existencia de fragmentos repetidos homólogos al transposón impala. El transposón está conservadas en grado distinto en las copias 05, 06, 07 (ó 08), 09 (ó 10) y 11, encontrándose prácticamente completo en la copia 05 , y solo en unos pocos nucleótidos en la copia 11. Todas las posibles copias del transposon Impala se encuentran muy próximas (entre 400 bp y 800 bp) al hipotético comienzo de la región codificante.

Dos codones de inicio están conservados en todas las copias estudiadas tanto de F. oxysporum f.sp. lycopersici como F. oxysporum f.sp. phaseoli, estando situados a $213 \mathrm{nt}(216 \mathrm{nt}$ en las copias 02 y 03$)$ y a 408 nt (411 nt en las copias 02 y 03, y 414 nt en la copia 04) respecto a la primera de las cisteínas que forma el dominio conservado del tipo dedo de zinc binuclear $\mathrm{Zn}(\mathrm{II})_{2} \mathrm{Cys}_{6}$.

Solo un motivo está conservado en todos los promotores de las copias analizadas, se trata de un motivo CAAT situado entre los dos codones de inicio descritos, 99 nt aguas arriba del codón de inicio posterior que se encuentra conservado. Entre este motivo CAAT y el codón de inicio ATG, existe otro codón de inicio ATG y que anteriormente había sido descrito como el más plausible como inicio de la traducción, si bien no existe en tres de las copias de la forma especial lycopersici $(07,09$ y 11).

Existe un motivo TATAAA conservado en cuatro de las copias $(01,02,03$ y 04) así como en ftf1a y ftf2, y situado $495 \mathrm{nt}$ aguas arriba del segundo de los codones ATG conservados (el que esta aguas abajo del motivo CAAT conservado).

En tres de las copias que no conservan el dominio TATAAA existen otros dominios TATA en un rango de 100 nucleótidos aguas arriba $\mathrm{O}$ abajo. Sin embargo, en la copia 09 (ó 10) no existe ningún motivo TATA que pueda iniciar la transcripción. En el caso de la copia 05 existen motivos TATA de inicio de la transcripción en el interior de la región repetida del transposón Impala. 


\subsubsection{4 - Análisis de la región codificante y la proteína resultante}

Se observa que existe una gran homología entre las regiones codificantes de las distintas copias estudiadas. En la Tabla 4. 9 (Pág. 103) se comprueba que la homología de la región codificante de estas copias con aquella de ftf1a está por encima del $90 \%$, excepto en uno de los casos.

Tanto los dominios como el intrón descritos en la caracterización de ftf1a existen en todas las copias. Cada uno de los seis aminoácidos cisteína que caracterizan el dominio dedo de zinc binuclear se marcó con un triángulo dorado. Dos de las copias (08 y 11) presentan en el interior del dominio una cisteína adicional (marcada con un triángulo amarillo).

La Figura 4. 30 (Pág. 108) muestra el alineamiento de las secuencias de aminoácidos deducidas de las correspondientes copias, incluye en la parte superior una representación gráfica del porcentaje de identidad. Se ha configurado con un valor de ventana de 6 nucleótidos. Las regiones verdes se corresponden con un valor del $100 \%$ de identidad. Las regiones en las que la identidad entre las distintas copias desciende, formándose valles en la gráfica, son infrecuentes. Existe una zona (identificable por un valle de color rojo en la gráfica de consenso de la figura 4. 30) formada por 7 aminoácidos (PIGPLQL) entorno a los $850 \mathrm{bp}$ del codon ATG de la copia de la forma especial phaseoli que no esta presente en ninguna de las copias de la forma especial lycopersici.

Las diferencias destacables en la región codificante se dan en la parte final de

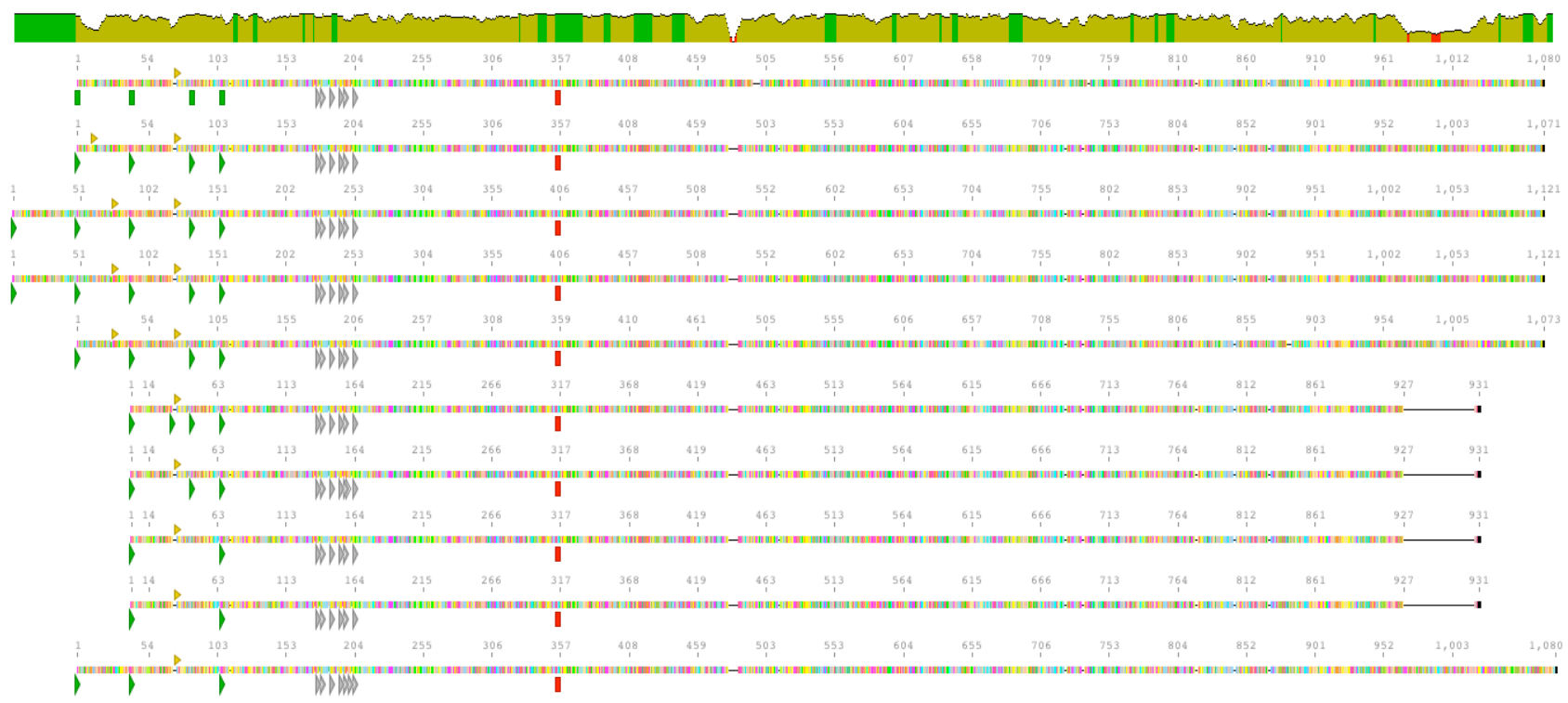

Figura 4. 30 - Esquema de la comparación de las secuencias aminoacídicas deducidas de ftf1a (primera línea) y las 9 copias diferentes de ftf1 y ftf2 en F. oxysporum lycopersicy (en orden numérico: 01, 02, 03, 04, 05, 06, 07, 09 y 11). En la parte superior la gráfica de consenso entre las secuencias, en verde $100 \%$ y en rojo por debajo del $50 \%$. Triángulos verde: Codones de inicio (metionina). Triángulos grises: Cisteinas del dominio dedo de zinc $\mathrm{Zn}(\mathrm{II})_{2} \mathrm{Cys}_{6}$. Cuadrado rojo: Cambio de fase (intrón secuencia nucleotídica). 
la misma, lo que hace que en cuatro de las copias $(05,06,07$ y 09) la proteína resultante sea de menor longitud pues el codón de parada esté 100 aminoácidos antes que en el resto de las copias.

Por el contrario, la secuencia proteica de las copias 01, 02, 03 y 04 es igual a la de ftf1a. La secuencia de la copia 11 tiene un tamaño similar a las de este último grupo, pero los aminoácidos que la forman son diferentes.

El dendrograma de semejanzas de las secuencias proteicas (Figura 4. 31 - Pág. 109) muestra la división en dos grandes grupos. En la parte superior del árbol, las secuencias tienen mayores diferencias, con la 05, 06 y 11 con pequeñas diferencias propias que las distinguen del resto. En la parte inferior del árbol, las secuencias del grupo tienen una

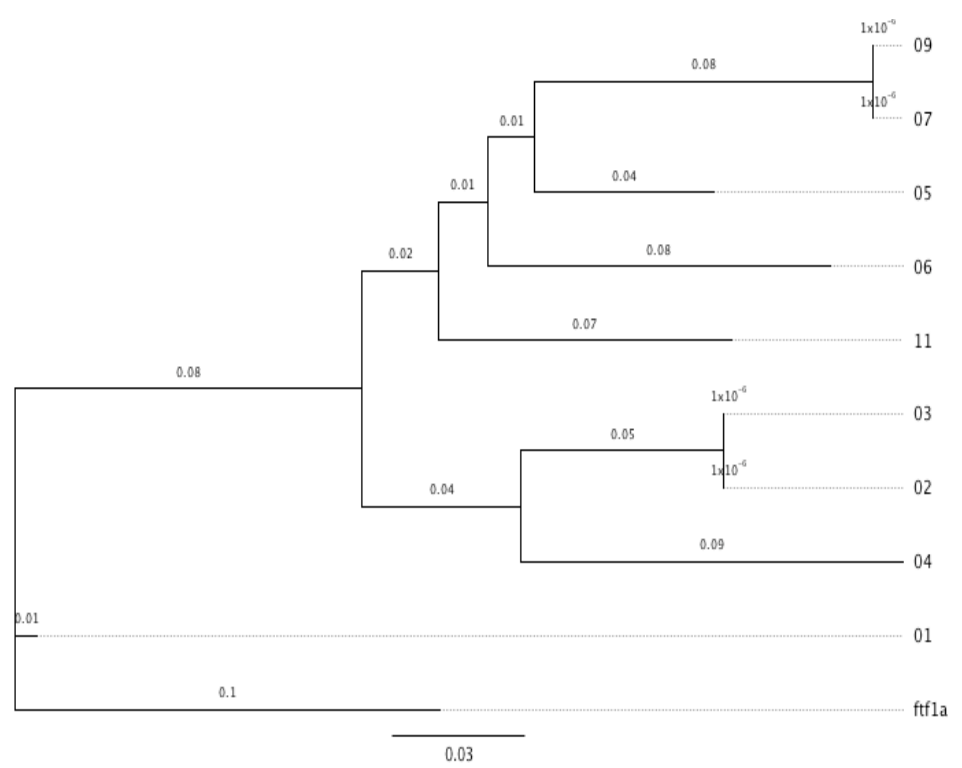

homología del 100\%.

Según la copia analizada, existen entre dos y cinco posibles codones de inicio de la traducción.

Si consideramos como codón de inicio de la traducción el más próximo al dominio $\mathrm{Zn}(\mathrm{II})_{2} \mathrm{Cys}_{6}\left(\right.$ codón $1^{\circ}$ ), la proteína resultante tendrá una longitud de entorno a 966-975 aa ó de 866 aa para el grupo de la parte superior.

La mayoría de las copias presenta un segundo codón muy próximo al anterior (codón $2^{\circ}$ ), que solo está ausente en las copias 07 y 09, que son las que en general son más diferentes (Figura 4. 30 - Pág. 108) y en la copia 11, que presenta posibles tamaños de proteína ligeramente mayores a los tamaños medio del resto del grupo.

\begin{tabular}{|c|c|c|c|c|c|c|}
\hline & \multicolumn{5}{c|}{ codón } \\
\hline 09 & $1^{\circ}$ & $2^{\circ}$ & $3^{\circ}$ & $4^{\circ}$ & $5^{\circ}$ \\
\hline 07 & 866 & - & 931 & - & - \\
\hline 05 & 866 & - & 931 & - & - \\
\hline 06 & 866 & 888 & 931 & - & - \\
\hline 11 & 976 & 888 & 931 & - & - \\
\hline 03 & 968 & 990 & 1033 & 1073 & 1121 \\
\hline 02 & 968 & 990 & 1033 & 1073 & 1121 \\
\hline 04 & 966 & 998 & 1033 & 1073 & - \\
\hline 01 & 966 & 988 & 1031 & 1071 & - \\
\hline ftf1a & 975 & 997 & 1040 & 1080 & - \\
\hline
\end{tabular}

Figura 4. 31 - Dendrograma de semejanzas de las secuencias aminoacídicas deducidas de ftf1a (F. oxysporum f.sp. phaseoli) y las copias de ftf1 y ftf2 en F. oxysporum f.sp. lycopersici. El valor en las ramas del árbol indica el número sustituciones por aminoácido.

Tabla 4. 11 - Longitud (en aminoácidos) de las posibles secuencias aminoacídicas deducidas de cada copia de los genes ftf1 y ftf2 en F. oxysporum f.sp. lycopersici, en función del codón de inicio considerado. 


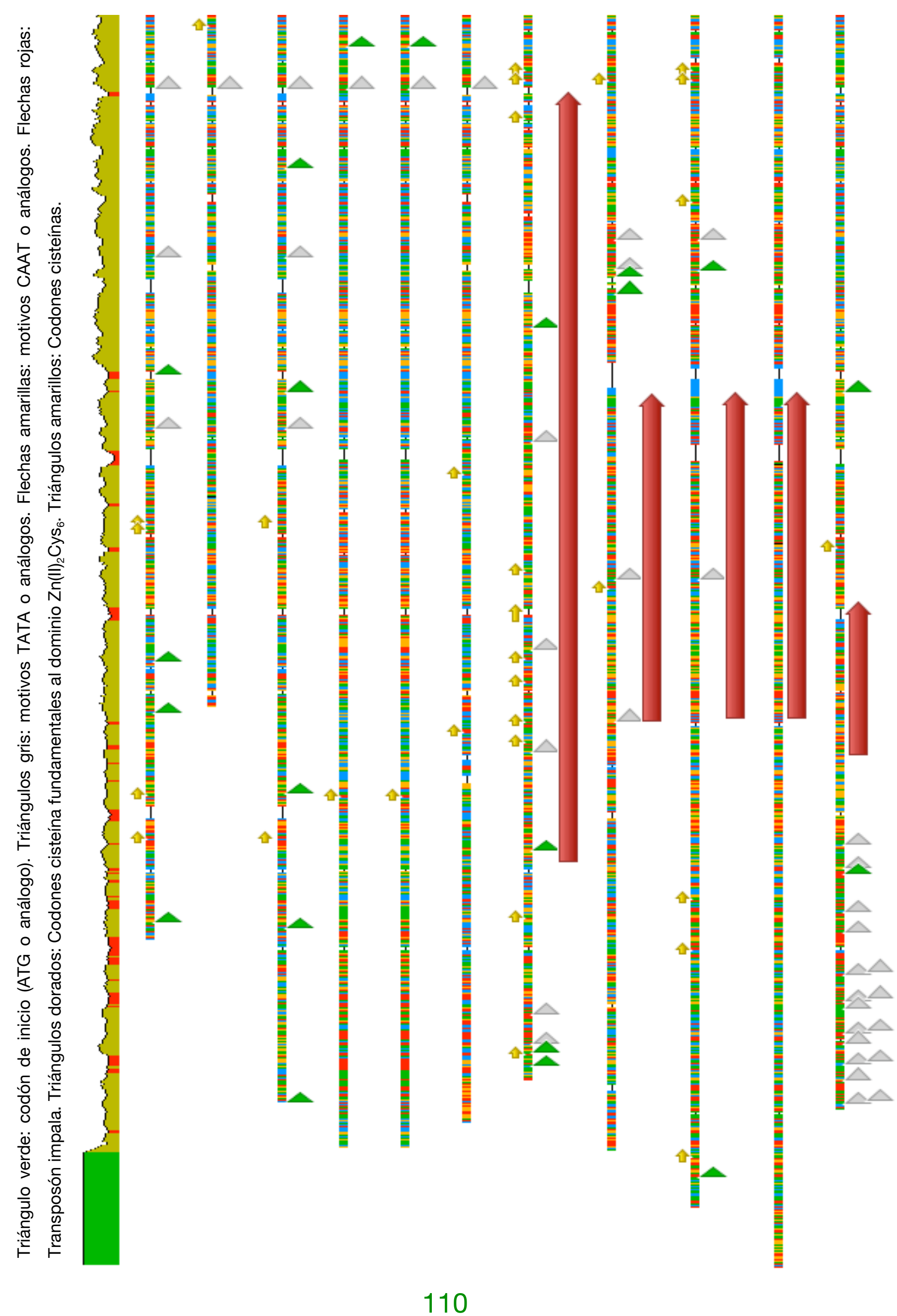




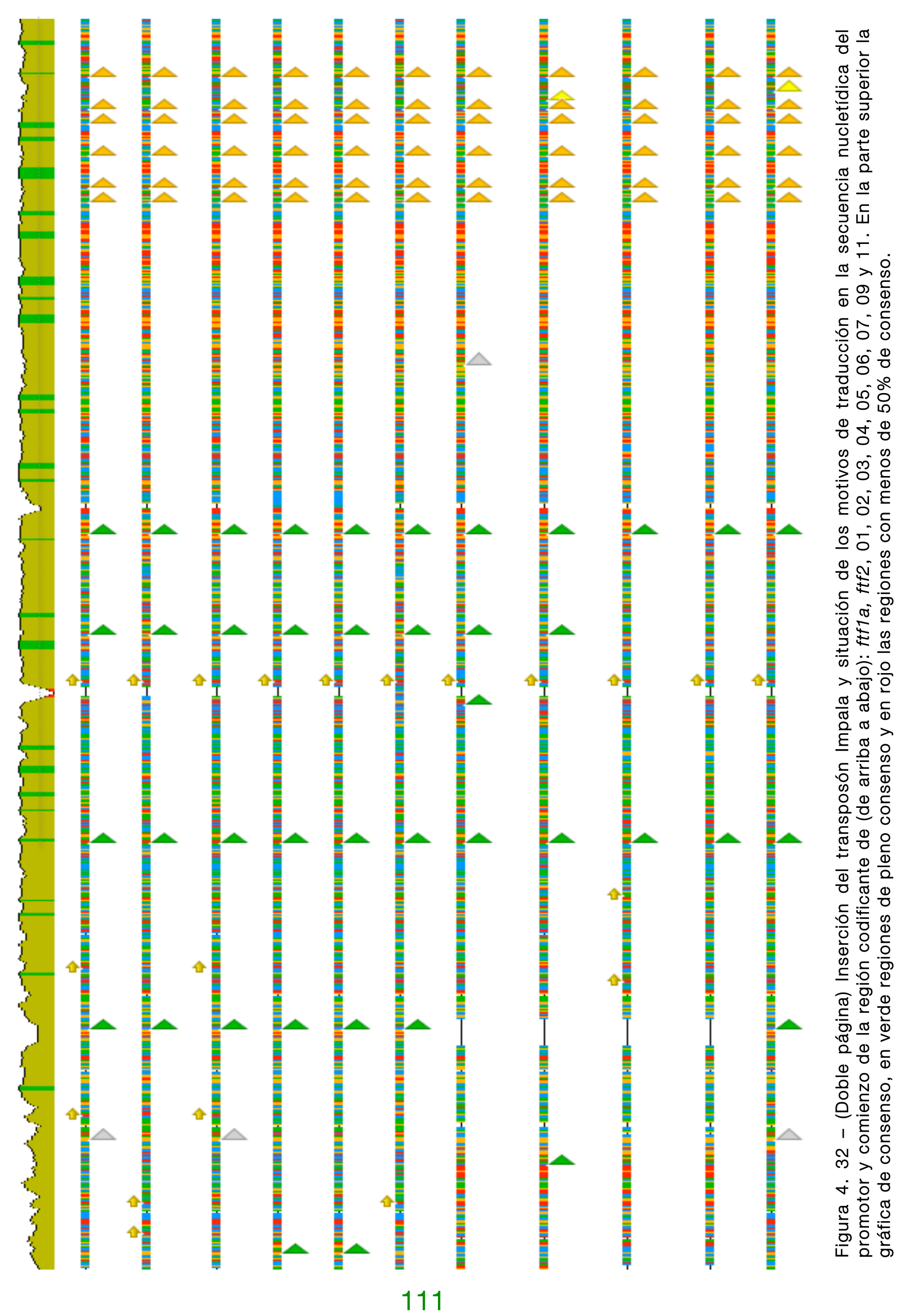


Si consideramos el otro codón de inicio conservado (codón $3^{\circ}$ ), las proteínas resultantes tienen 1031-1040 aa en el primer grupo y 930 aa en el segundo grupo.

Aguas arriba de estos dos codones de inicio conservados en todas las copias, existe otro codón de inicio común a las copias con proteína de mayor tamaño (codón $4^{\circ}$ ). En ese caso la proteína tiene entre 1071 aa (01) y 1080 aa (ftf1a y 08).

Además, las copias 02 y 03 presentan un codón de inició situado aguas arriba de los ya comentados (codón $5^{\circ}$ ), en este último caso, la proteína tiene un tamaño de 1.121 aa, que es la máxima longitud teórica. 


\section{4 - Análisis fenotípico de los transformantes silenciados}

\section{en ftf1 y ftf2}

4.4.1 - Silenciamiento de los genes fff1 y fff2

4.4.1.1 - Construcción de silenciamiento

Las experiencias previas en otros hongos filamentosos demuestran que la mayor eficiencia de silenciamiento se basa en diseños que incluyen dos fragmentos iguales de aproximadamente $400 \mathrm{bp}$ del gen diana que se disponen en sentidos enfrentados.

Así mismo, se ha comprobado que la eficiencia también es mayor cuando entre los fragmentos se dispone un fragmento de unos 100bp distinto a los anteriores, típicamente un intrón, que facilita la formación del bucle por ese punto.

Elegimos como región diana para nuestra construcción de silenciamiento una secuencia perteneciente al segundo exón, que es $100 \%$ homóloga en los genes ftf1 y ftf2 en F. oxysporum f.sp. phaseoli.

Nuestro diseño se basó en un plásmido binario, que incluya las secuencias de reconocimiento LB (Left Border) y RB (Right Border) de la bacteria A. tumefaciens, así como los genes de virulencia de la misma

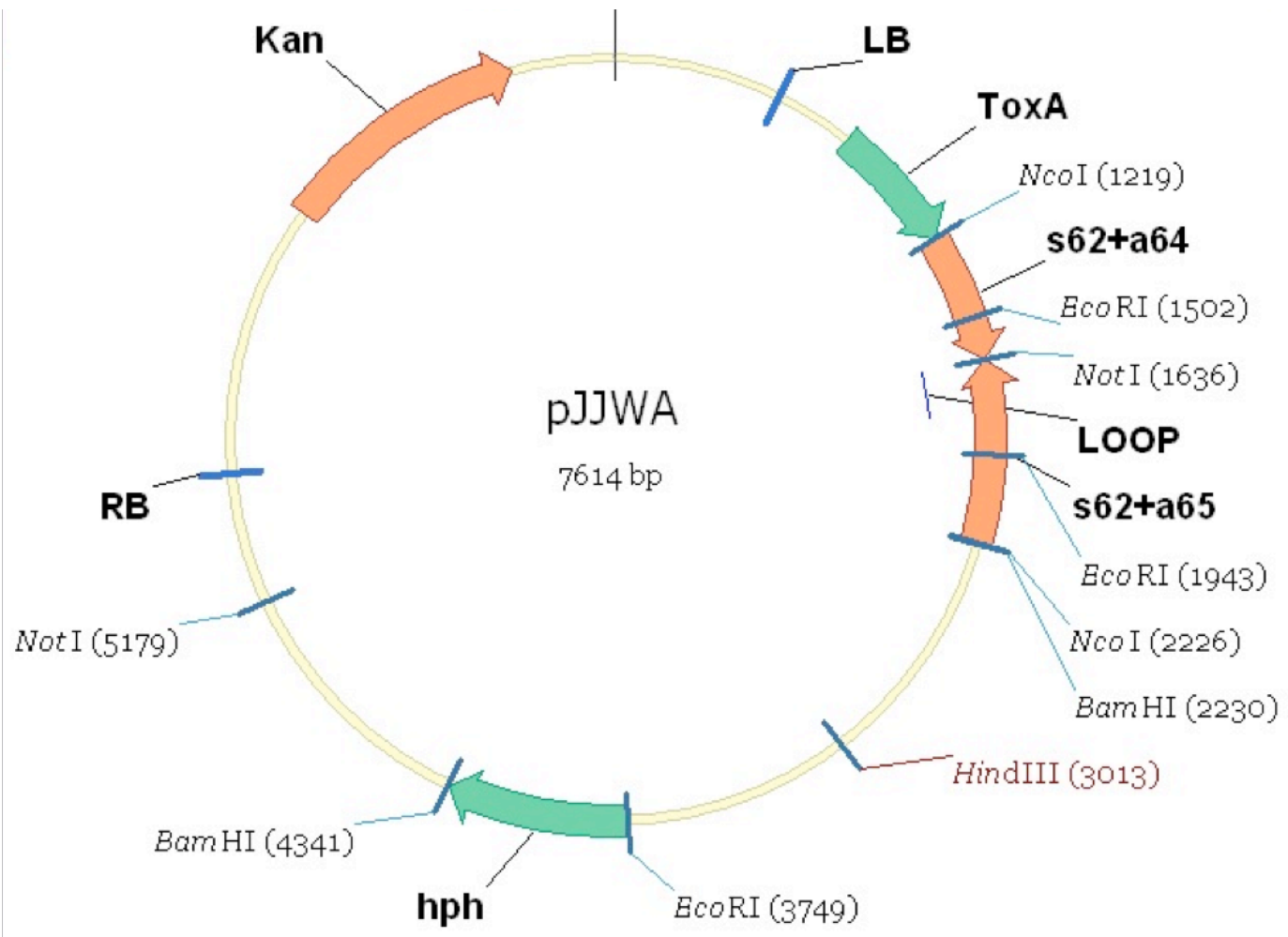

Figura 4. 33 - Esquema del plásmido binario pJJWA construido para el silenciamiento de los genes ftf1 y ftf2. LB y RB: Left border y Right border, que delimitan el fragmento de ADN que se transfiere en la transformación. ToxA: Promotor del gen ToxA de $P$. trtici-repentis. s62+a64: Fragmento amplificado de ftf1 con los oligonucleótidos s62 y a64. s62+a65: Fragmento amplificado de ftf1 con los oligonucleótidos s62 y a65. LOOP: Zona del fragmento s62+a65 no presente en s62+a64 donde se genera el bucle. hph: gen de resistencia higromicina fosfotransferasa. Kan: casete de resistencia bacteriana a la kanamicina. 
y el gen de resistencia a la kanamicina.

Entre estas regiones de reconocimiento se dispone un cassette que incluye el gen de resistencia a la higromicina y nuestros fragmentos duplicados tal y como se ha indicado, bajo el control del promotor constitutivo del gen ToxA de $P$. triticirepentis.

El plásmido se construyó partiendo de un plásmido binario denominado pMB302 que ya incluía los elementos necesarios a excepción de los fragmentos del gen de interés y el separador. Este plásmido se linearizó mediante una digestión con Ncol, cuya diana se encuentra inmediatamente después del promotor ToxA.

Con el objetivo de simplificar las digestiones en lugar de incluir un intrón se optó por una estrategia en la que uno de los fragmentos del gen diana es 100 pb más grande que el otro.

Se diseñaron tres oligonucleótidos distintos. El primero (S62), se usó en las dos amplificaciones e incluye un sitio reconocido por $\mathrm{Ncol}$ en el extremo 5' que permite la hibridación al plásmido linealizado. Los otros dos (A64 y A65), incluyen un sitio de reconocimiento Notl (de 8 bp de longitud). Se diferencian por hibridar en la región de interés en puntos separados por $173 \mathrm{bp}$, dando lugar a amplicones de 417 bp y 590 bp, respectivamente.

Se realizó una ligación múltiple con los tres fragmentos. Esto hace que además del plásmido buscado con un fragmento de cada longitud, también obtuviéramos como producto de la ligación plásmidos formados por dos fragmentos del mismo tipo. Ello nos obligó a verificar los productos mediante una digestión con Notl y $\mathrm{Ncol}$ buscando dos bandas de distinto tamaño (417 bp y 590 bp) y descartando aquellos plásmidos producto de la ligación que solo mostrasen una banda en los geles de comprobación.

\subsubsection{2 - Transformación y selección}

El plásmido binario terminado, denominado pJJWA, fue introducido en varias estirpes distintas de $F$. oxysporum f.sp. lycopersici y f.sp. phaseoli, utilizando el sistema de transformación por $A$. tumefaciens.

Se transformaron un aislado supervirulento (SP13), altamente virulento (SP1), débilmente virulento (SP4) y no

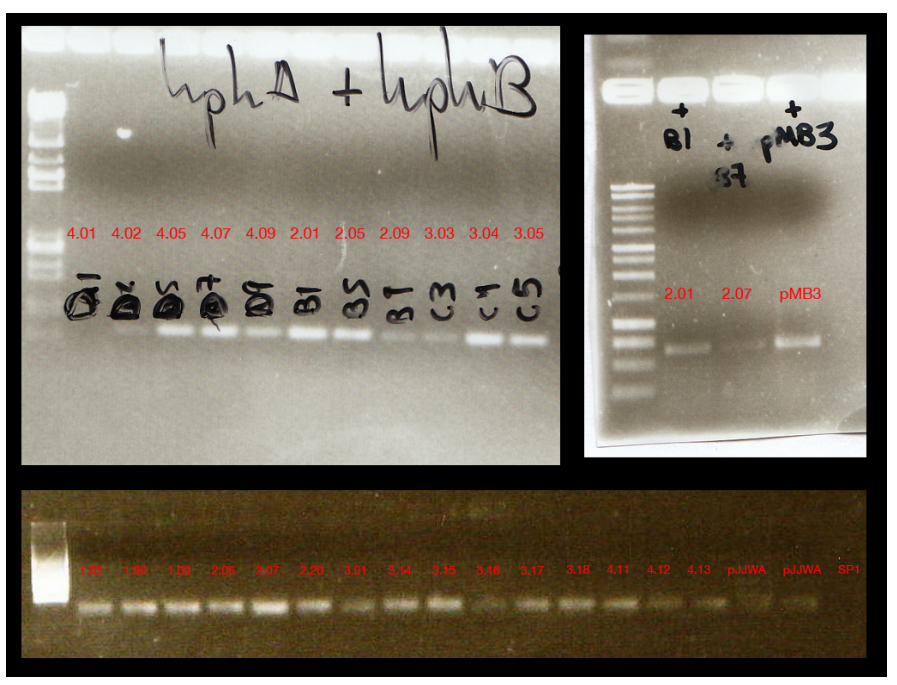

Figura 4. 34 - Amplificación mediante PCR de distintos fragmentos en los transformantes obtenidos con la construcción de silneciamiento. Arriba izq.: Amplificación del cassette de resistencia a la higromicina con los oligonucleótidos hphA y hphB en varios transformantes. Arriba der.: Comparación del amplicón de la higromicina con el del plásmido pMB3 (que tiene la misma resistencia) (Ramos et al., 2007) como control positivo. Abajo: Amplificación del promotor ToxA y el primero de los fragmentos del gen diana con los oligonucleótidos ToxA_FWD y s64. 
patógeno (AB82).

Se verificó la amplificación por PCR en los transformantes que mostraban un crecimiento en PDA con higromicina, del cassete de resistencia a la higromicina con los oligonucleótidos hphA y hphB (0,6 Kb), asi como la amplificación del promotor de la construcción ToxA y parte del fragmento diana con los oligonucleótidos ToxA_FWD y s64 (0,84 Kb) (Figura 4. 34 - Pág. 114).

Se realizaron tres repeticiones del proceso de transformación completo para cada una de las cuatro estirpes. Se observaron variaciones de la eficiencia de transformación, si bien más achacables a parámetros como la concentración de los cultivos de $A$. tumefaciens y de esporas de $F$ oxysporum, que a los propios aislados, que apenas presentaban variaciones entre ellos.

En el presente trabajo, los transformantes se nombran mediante dos números separados por un punto. El primero hace referencia a la estirpe silvestre de la que proceden y el segundo al número que hacen dentro de su tipo. Se nombran como 1.XX, 2.XX, 3.XX ○ 4.XX los transformantes derivados de SP13, SP1, SP4 O AB82, respectivamente. Por ejemplo, el transformante 3.15 es el decimoquinto transformante silenciado obtenido a partir de SP4.

4.4.2 - Expresión de ftf2 en los transformantes silenciados

Disponemos de los oligonucleótidos

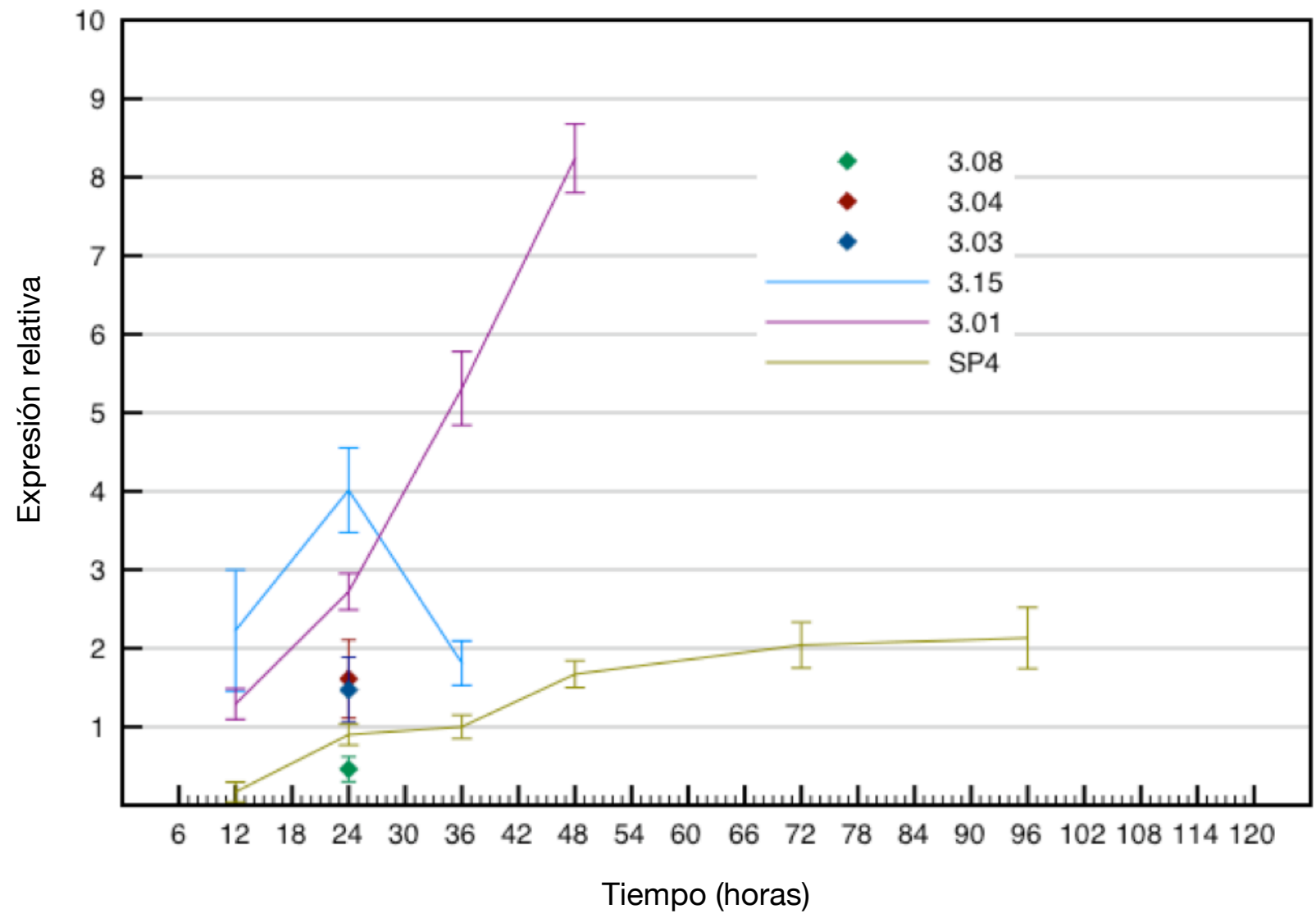

Figura 4. 35 - Expresión de ftf2 cuantificada mediante Real-time PCR con cebadores que hibridan fuera de la región usada en la construcción de silenciamiento de los transformantes silenciados $3.01,3.03,3.04,3.08$ y 3.15 respecto a la estirpe tipo silvestre SP4. 
usados para el estudio de la expresión de ftf2 en aislados silvestres (ftf2_espe3_FWD y ftf2_espe3_REV), y que hibridan aguas arriba de la región usada en la construcción de silenciamiento. Se realizó un estudio (Figura 4. 35 - Pág. 115) de la expresión de fftf2, mediante estos cebadores, en el transformante 3.01, y se comparó con la expresión en FOP-SP4, estirpe de la cual procede el transformante. Como en los casos anteriores, la expresión de ftf2 se ha normalizado respecto al valor de expresión de SP4 tras 36 horas en cultivo.

La expresión detectada en 3.01 presenta una progresión constante y a un ritmo mucho más rápido que el de de SP4. Al menor de los tiempos, 12 horas, la expresión de ftf2 en 3.01 duplica la de SP4, y dado su mayor ritmo de crecimiento a las 48 horas, la expresión en 3.01 es cuatro veces mayor que la de SP4. Para verificar estos resultados, se realizó también un estudio de expresión de ftf2 en el tiempo con el transformante 3.15 (Figura 4. 35 - Pág. 115). La expresión también es mucho mayor que en el tipo silvestre SP4 desde la primera medición (12 horas) y aumenta al mismo ritmo que el observado en 3.01. Sin embargo, parece reducirse considerablemente a las 36 horas, si bien creemos que se trata de un error pues no son esperables diferencias tan claras con FOP-SP4 y 3.01.

También realizamos una medición puntual de la expresión de ftf2 a las 24 horas

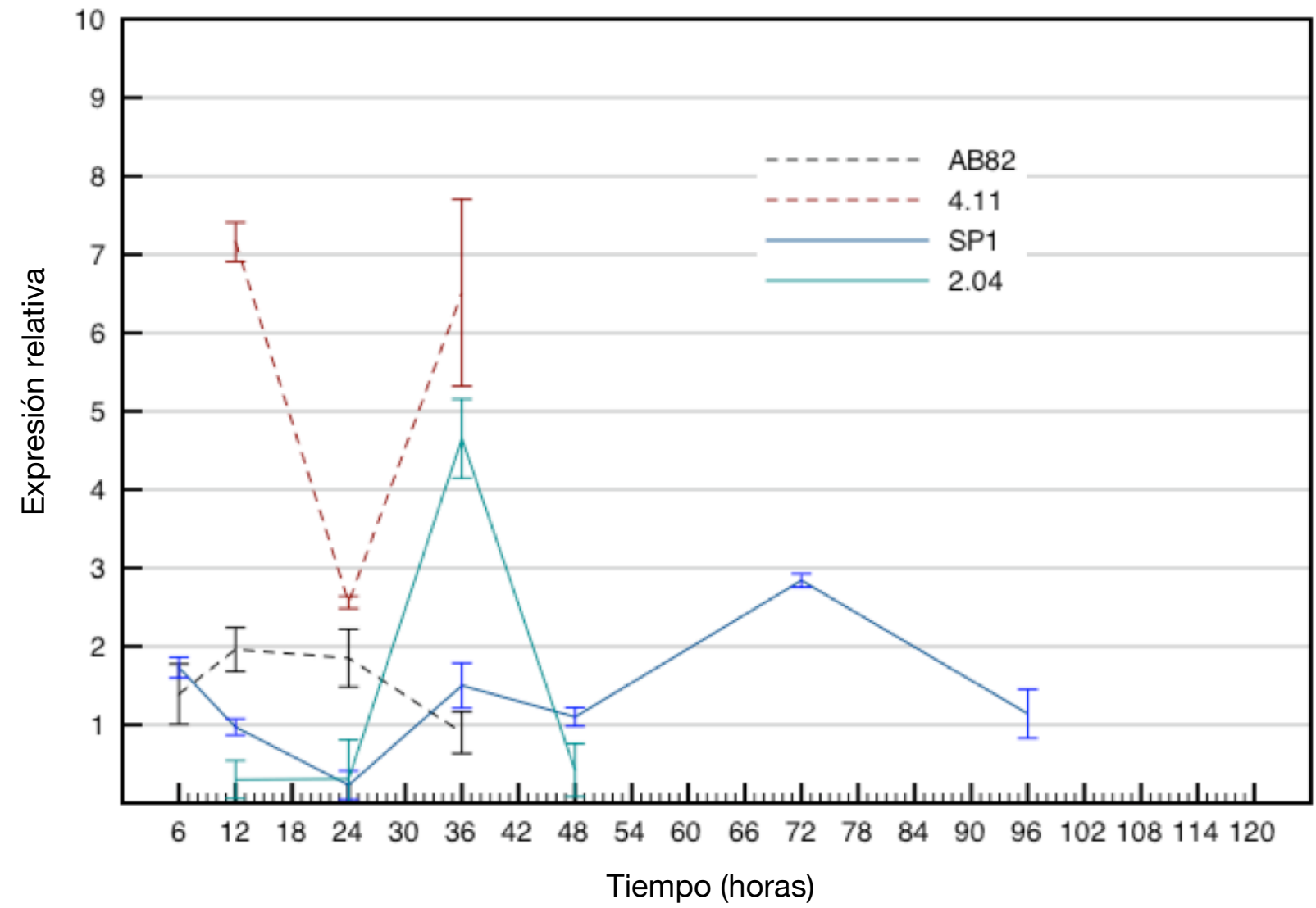

Figura 4. 36 - Expresión de ftf2 cuantificada mediante Real-time PCR mediante cebadores que hibridan fuera de la región usada en la construcción de silenciamiento de los transformantes silenciados 2.04 y 4.11 respecto a las estirpes silvestres SP1 y AB82. 
en los transformantes $3.03,3.04$ y 3.08 (Figura 4. 35 - Pág. 115). En los dos primeros la expresión era mayor que en el tipo silvestre SP4. Entre todos los transformantes estudiados, solo 3.08 presenta una expresión menor que SP4.

En la Figura 4. 36 (Pág. 116) se presenta el estudio de la expresión en el tipo silvestre SP1 y el tranformante derivado del mismo 2.04. Como los oligonucleótidos usados son los diseñados para la detección específica de ftf2 (y que están fuera de la región usada en la construcción), se descartan interferencias de ftf1, y es posible comparar los resultados con las gráficas anteriores. Aunque no queda claro por la mediciones dispares a tiempos mayores, aparentemente la expresión es parecida entre el transformante 2.04 y el tipo silvestre SP1 a tiempos menores, pero presenta un pico a las 36 horas. También se muestra la expresión del transformante 4.11 y la estirpe silvestre no patógena AB82. La expresión de 4.11 obtenida es muy variable en el tiempo, pero siempre es mayor en el transformante que en el tipo silvestre.

\begin{tabular}{|cc|c|c|c|c|}
\hline Muestra & Ct & dCt & dCt std err & ddCt & RQ \\
\hline $2.04-06 h$ & 21,904 & 0,26 & 0,575 & $-0,32$ & 1,25 \\
\hline $2.04-12 h$ & 19,877 & 2,328 & 0,243 & 1,74 & 0,30 \\
\hline $2.04-24 h$ & 18,76 & 2,265 & 0,496 & 1,68 & 0,31 \\
\hline $2.04-36 h$ & 20,226 & $-1,632$ & 0,504 & $-2,22$ & 4,65 \\
\hline $2.04-48 h$ & 25,885 & 1,823 & 0,338 & 1,24 & 0,42 \\
\hline $3.01-12 h$ & 20,848 & 0,217 & 0,196 & $-0,37$ & 1,29 \\
\hline $3.01-24 h$ & 19,702 & $-0,86$ & 0,232 & $-1,44$ & 2,72 \\
\hline $3.01-36 h$ & 19,272 & $-1,825$ & 0,469 & $-2,41$ & 5,31 \\
\hline $3.01-48 h$ & 21,275 & $-2,459$ & 0,438 & $-3,04$ & 8,24 \\
\hline $3.03-24 h$ & 18,795 & 0,029 & 0,415 & $-0,56$ & 1,47 \\
\hline $3.04-24 h$ & 20,358 & $-0,107$ & 0,499 & $-0,69$ & 1,61 \\
\hline $3.08-24 h$ & 21,267 & 1,72 & 0,159 & 1,14 & 0,46 \\
\hline $3.15-12 h$ & 21,115 & $-0,571$ & 0,771 & $-1,16$ & 2,23 \\
\hline $3.15-24 h$ & 17,693 & $-1,421$ & 0,539 & $-2,01$ & 4,01 \\
\hline $3.15-36 h$ & 18,279 & $-0,273$ & 0,283 & $-0,86$ & 1,81 \\
\hline $4.11-06 h$ & 24,632 & $-3,327$ & 0,372 & $-3,91$ & 15,04 \\
\hline $4.11-12 h$ & 25,406 & $-2,255$ & 0,25 & $-2,84$ & 7,16 \\
\hline $4.11-24 h$ & 20,614 & $-0,773$ & 0,076 & $-1,36$ & 2,56 \\
\hline $4.11-36 h$ & 21,075 & $-2,118$ & 1,191 & $-2,70$ & 6,51 \\
\hline
\end{tabular}

Tabla 4. 12 - Expresión de ftf2 cuantificada mediante Real-time PCR mediante cebadores que hibridan fuera de la región usada en la construcción de silenciamiento. Los datos de las estirpes silvestres están en la Tabla 4. 5 (Pág. 88). Los valores están normalizados respecto al valor de SP4 a las $36 \mathrm{~h}$ (Tabla 4.5). 


\begin{tabular}{|c|c|c|c|c|c|}
\hline Muestra & \multicolumn{1}{c}{ Ct } & dCt & dCt std err & ddCt & RQ \\
\hline $3.01-24 h$ & 24,805 & 5,181 & 0,121 & $-1,839$ & 3,578 \\
\hline $3.03-24 h$ & 24,552 & 5,624 & 0,269 & $-1,396$ & 2,632 \\
\hline $3.04-24 h$ & 25,027 & 4,204 & 0,35 & $-2,816$ & 7,042 \\
\hline $3.08-24 h$ & 24,11 & 4,39 & 0,133 & $-2,63$ & 6,190 \\
\hline SP4 - 24h & 24,542 & 4,748 & 0,186 & $-2,272$ & 4,830 \\
\hline
\end{tabular}

Tabla 4. 13 - Expresión de ftf2 cuantificada mediante Real-time PCR mediante cebadores que hibridan en la región usada en la construcción de silenciamiento (hairpin). Los valores están normalizados respecto al valor de SP4 a las 36h (Tabla 4.5).

La bibliografía no es clara sobre si es preferible usar para la detección de la expresión la región usada en la construcción de silenciamiento o una región externa a la construcción. Por ello, también se diseñaron nuevos oligonucleótidos (homoFTF_FWD y
homohFTF_REV) que hibridan en el interior de la región usada para la construcción de silenciamiento (denominada hairpin en las figuras).

En la Figura 4. 37 (Pág. 118) se observa la expresión de ftf2 detectada tras 24

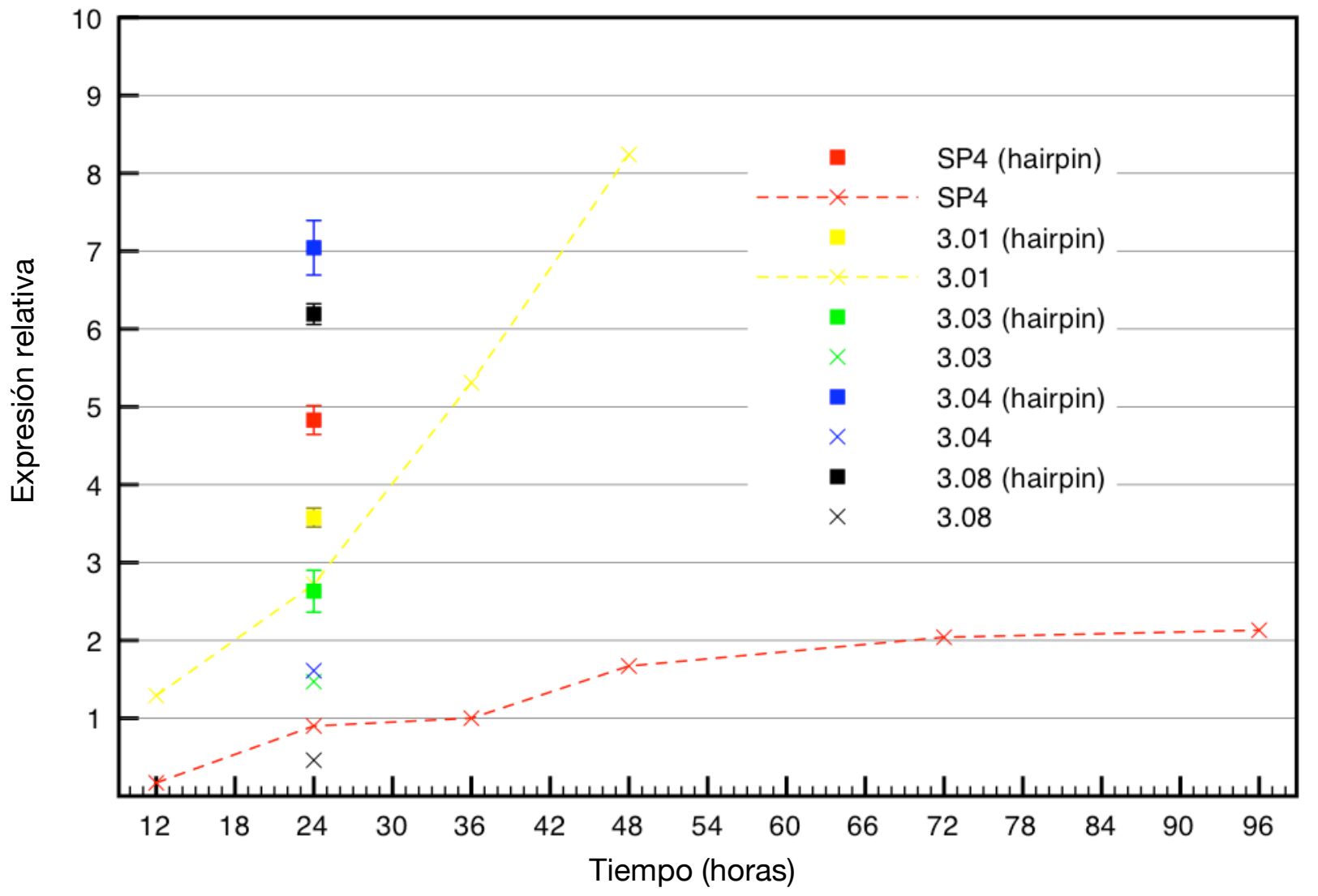

Figura 4. 37 - Expresión de ftf2 cuantificada mediante Real-time PCR mediante cebadores que hibridan en la región usada en la construcción de silenciamiento (hairpin) en los transformantes $3.01,3.03,3.04$ y 3.08 y el tipo silvestre SP4 (cuadrados); y su comparación con las mediciones anteriores con cebadores que hibridan fuera de la región usada en la construcción de silenciamiento (aspas y líneas punteadas). 
horas de crecimiento en medio de cultivo líquido del aislado silvestre SP4 y los transformantes $3.01,3.03,3.04$ y 3.08 . Se incluye como referencia la expresión de ftf2 medida fuera de la región usada en la construcción en los mismos transformantes, a las 24 horas, y en el caso de SP4 y 3.01 a distintos tiempos.

En todos los casos, la expresión de ftf2 cuantificada mediante los cebadores que hibridan en la región usada en la construcción (hairpin) es mayor que la medida aguas arriba (fuera de la región usada en la construcción). Es especialmente claro en el caso de 3.04 (en azul: 3.04 frente a 3.04 hairpin) que es 7 veces mayor y 3.08 (en negro: 3.08 frente a 3.08 hairpin), que en la medición anterior era la mitad del tipo silvestre y en esta nueva medición es 6 veces mayor.

En la medición anterior (representado por aspas), solo 3.08 presentaba una expresión inferior a SP4. Sin embargo, en este caso (representado por cuadrados) los transformantes 3.04 y 3.08 presentan mayor expresión de ftf2 que el tipo silvestre (SP4), mientras que 3.01 y 3.03 presentan una menor expresión de ftf2 que el tipo silvestre.

4.4.3 - Alteración del crecimiento y la esporulación en los transformantes silenciados

\subsubsection{1 - Fenotipo de los tranformantes silenciados} de F. oxysporum f.sp. Iycopersici

A diferencia de $F$. oxysporum f.sp. phaseoli, no conocemos aislados de $F$. oxysporum f.sp. lycopersici en los que esté ausente el gen ftf1. Al haber elegido como región diana para el silenciamiento una completamente similar entre ftf1 y ftf2, creemos se silencian ambos genes.

Se transformó F. oxysporum f.sp. lycopersici strain I (Phytopathology Lab. Wageningen University). Tras el proceso de transformación se observó que había diferencias de crecimiento entre la mayoría de los transformantes y el tipo silvestre. Esta alteración era más notoria en medios con higromicina.

Con el objeto de descartar modificaciones debidas al proceso mismo de transformación, en paralelo a nuestra transformación se realizó otra con la construcción pS3, que al igual que pJJWA, es un plásmido binario con resistencia a la higromicina que se integra por recombinación no homóloga.

En la Figura 4. 38 (Pág. 120) se muestra el crecimiento en medio de cultivo PDA sólido de colonias de tres transformantes de $F$. oxysporum f.sp. lycopersici (W1, W2 y W4) con el tipo silvestre (WT) y el control de transformación comentado (control transform.). En la columna izquierda los transformantes W1 (primera fila), W2 (segunda fila) y W4 (tercera fila) se cultivaron en PDA. El transformante W1 muestra limitación del crecimiento en medio con higromicina, pero no en medio sin antibiótico. El trasformante W2 muestra una limitación parecida en ambos medios. El transformante W4 muestra reducción del crecimiento en ambos medios, si bien es más acusada en medio con higromicina. 
En la columna derecha se crecieron en medio PDA con $50 \mu \mathrm{g} / \mathrm{ml}$ de higromicina. En este caso todos los transformantes crecieron de forma reducida. El tipo silvestre no creció al no portar el cassete de resistencia al antibiótico y el transformante con la construcción pS3 (control transform.) creció con normalidad.

\subsubsection{2 - Crecimiento en medio sólido de los}

tranformantes silenciados de $F$. oxysporum f.sp.

phaseoli

Nos centramos en la transformación de aislados de la forma especial phaseoli porque disponemos de una colección mayor, en la que ftf1 y ftf2 han sido mejor

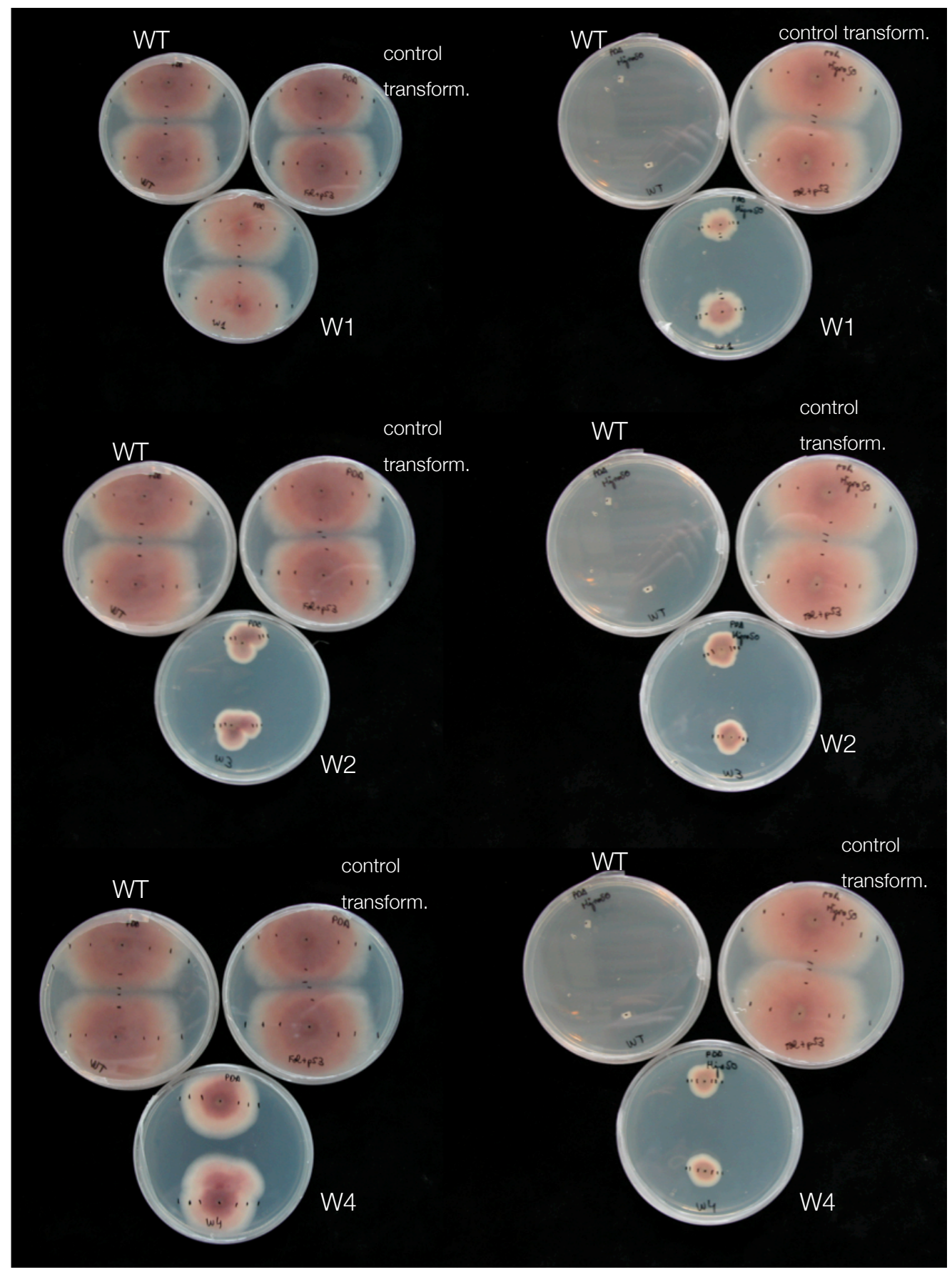

Figura 4. 38 - Crecimiento en PDA (columna de la izq.) y PDA+higromicina (columna der.) de una aislado silvestre de $F$. oxysporum f.sp. lycopersici, un transformante con un plásmido con resistencia a la higromicina (como control de la transformación) y un transformante con el plásmido pJJWA (W1, W2 o W4). 
caracterizada. Disponemos de aislados no patógenos y débilmente virulentos en los que no está presente ftf1, lo que nos permitirá analizar el silenciamiento del gen ftf2. Asi mismo, disponemos de estirpes patógenas con tres tipos de virulencia, lo que nos permitirá valorar el papel de ftf1 en el proceso de infección como gen de virulencia. De esta forma, construimos cuatro colecciones independientes y viables de transformantes a partir de un aislado supervirulento (SP13), altamente virulento (SP1), débilmente virulento (SP4) y no patógeno (AB82).

Todos los transformantes así como sus correspondientes estirpes silvestres se cultivaron en PDA durante cinco días, tomando medidas (en centímetros) del radio de la extensión de la colonia del hongo cada veinticuatro horas. Esta medida del radio es proporcional a la tasa de crecimiento medida en superficie y por tanto sus resultados análogos. Este experimento se repitió dos

Figura 4. 39 - Crecimiento en medio PDA de la estirpe supervirulenta SP13 y sus transformantes (1.XX).

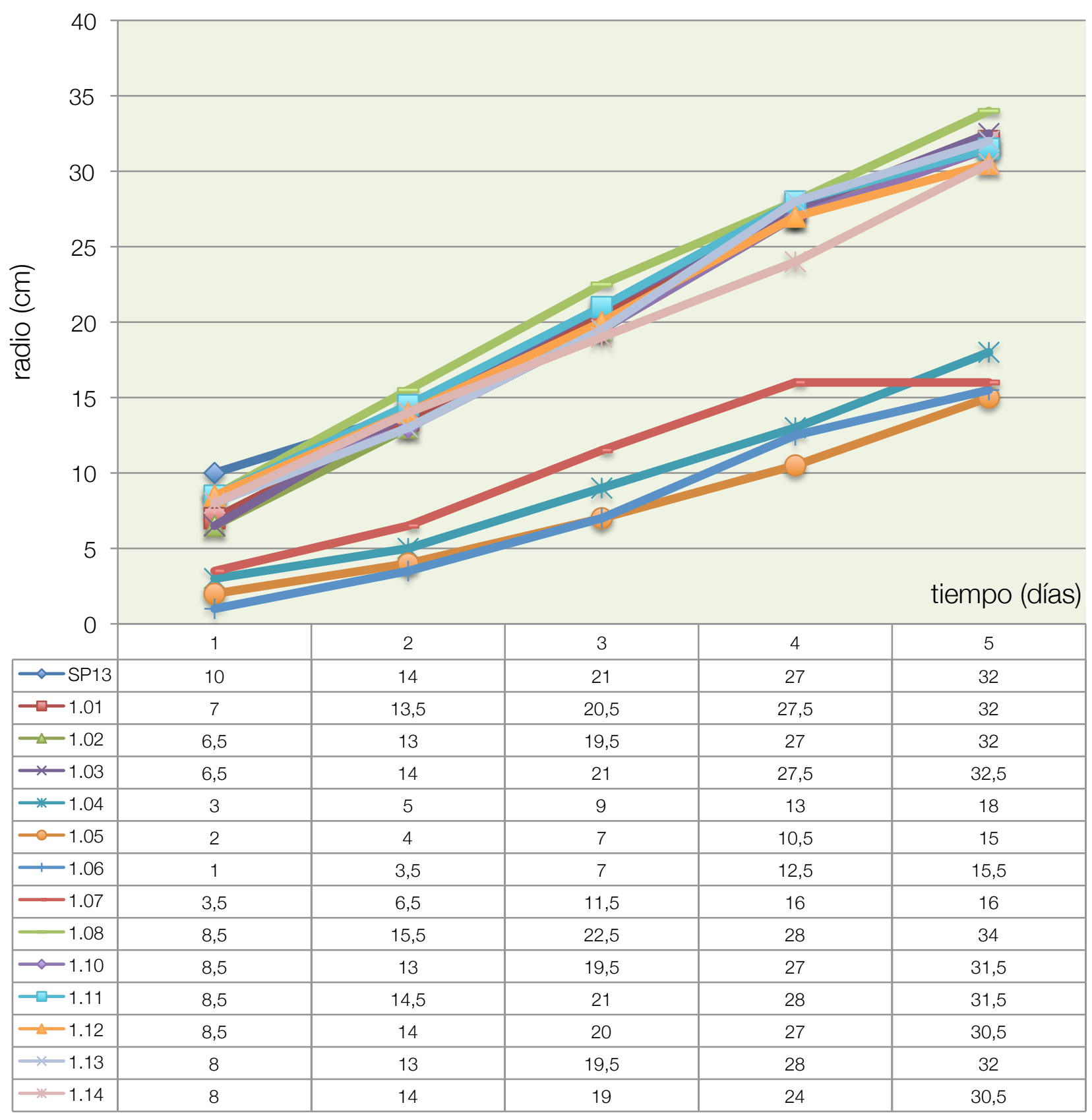


veces.

Cuando comparamos los datos de un transformante con los del tipo silvestre del que deriva, observamos que para los cuatro tipos o grupos transformados, los aislados se dividen claramente en dos grupos. Existe un grupo de transformantes que siempre presenta un crecimiento claramente inferior. En la bibliografía, a los transformantes que muestran los fenotipos más diferentes al tipo silvestre se les denomina "strong silenced" o fuertemente silenciados. Sin embargo, también se observa que una gran parte de los transformantes apenas presentan variación respecto al tipo silvestre.

En la Figura 4. 39 (Pág. 121) se muestran los datos del tipo silvestre supervirulento SP13 y los transformantes derivados del mismo. Se trata de aislados que presentan una copia de ftf2 y cinco

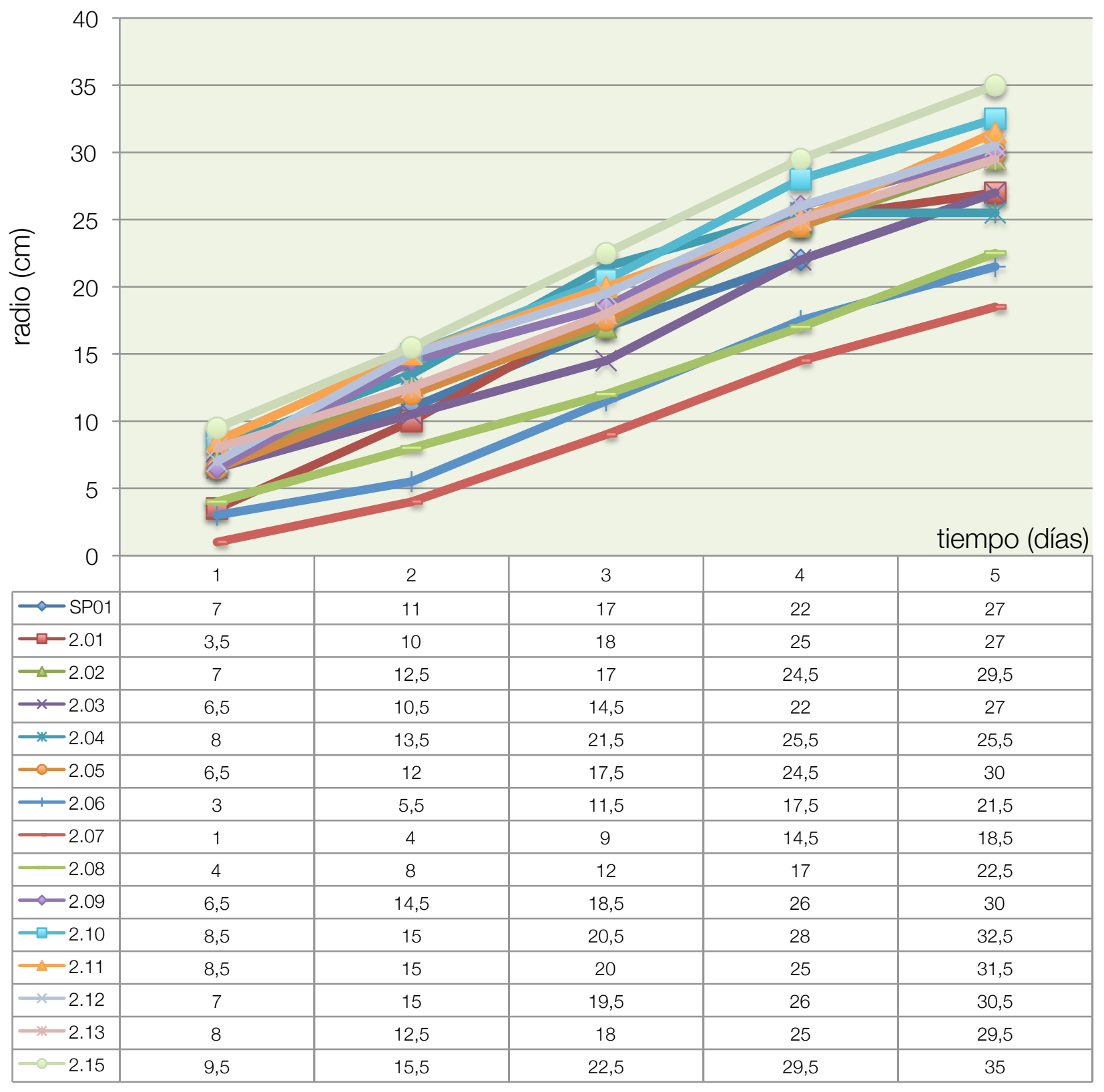

Figura 4. 40 - Crecimiento en medio PDA de la estirpe altamente virulenta SP1 y sus transformantes $(2 . \mathrm{XX})$. 
copias de $f t f 1$. Podemos agrupar cuatro de los transformantes $(1.04,1.05,1.06$ y 1.07$)$, que presentan un radio de la colonia entorno a los $16 \mathrm{~cm}$ tras cinco días, que es la mitad que el tipo silvestre $(32 \mathrm{~cm})$ en el mismo tiempo. El resto de los transformantes presentan tasas de crecimiento similares al tipo silvestre, y los que presentan valores mayores al tipo silvestre se pueden incluir dentro del margen de error del mismo. Un análisis de la varianza (One-way ANOVA) con los valores a los cinco días verifica la significación estadística de los dos grupos $(P<0,0001$; F-test=596,52).

En el caso del tipo silvestre altamente virulento SP01 (Figura 4. 40 - Pág. 122), que tienen una copia de ftf2 y cuatro de ftf1. Se observa un continuo de disminución del crecimiento, que alcanza un valor mínimo con 2.06, 2.08 y, especialmente, con 2.07. Estos últimos forman un grupo diferenciado $(P=0,00017 ; \quad F$-test=27,12) del resto, que muestran tasas de crecimiento parecidas al tipo silvestre.

Los tipos silvestres débilmente virulentos (como SP4) y no patógeno (como AB82), así como los transformantes que derivan de ellos, tienen una copia de ftf2 y ninguna de ftf1. En la Figura 4. 42 (Pág. 126), se comprueba que los transformantes de SP4 forman dos grupos, pero el que agrupa a los fuertemente silenciados es más numeroso que en los casos anteriores. Los transformantes $3.14,3.15,3.16,3.17,3.18 \mathrm{y}$ 3.19 presentan radios de crecimiento entorno a $18 \mathrm{~cm}$ tras 5 días. El transformante 3.01 muestra una alteración mayor y su crecimiento es muy inferior $(10,5 \mathrm{~cm}$ tras 5 días) al tipo silvestre y los transformantes silenciados indicados anteriormente. El resto de los transformantes se agrupa entorno al tipo silvestre, que incluso presenta un valor $(32 \mathrm{~cm})$ menor a la media de este grupo (34 $\mathrm{cm}$ ). El análisis de la varianza (One-way ANOVA) verifica la separación $(P<0,0001$; $F-$ test=249,56) entre el grupo formado por 3.01, $3.14,3.15,3.16,3.17,3.18$ y 3,19; y el resto de los transformantes más el tipo silvestre (SP4).

La Figura 4.43 (Pág. 127) que agrupa al tipo silvestre no patógeno $A B 82$ y sus transformantes son los que más claramente muestra el doble agrupamiento, y al tiempo la existencia de un gradiente continuo dentro de los mismos. Así mismo, el tipo silvestre presenta una tasa de crecimiento mayor que los transformantes y se distingue de ellos. Como en los casos anteriores, tres transformantes $(4.11,4.12$ y 4.13$)$ presentan tasas de crecimiento inferior (entre 11 y 13 $\mathrm{cm}$ tras cinco días). El análisis de la varianza verifica la separación (con un nivel de confianza del 99\%) del grupo formado por estos tres transformantes con el resto de transformantes $(P<0,0001 ;$ F-test $=81,99)$ y a su vez con el tipo silvestre $(P=0,0034 ; F-$ test $=289,0)$. El resto de los transformantes forma un grupo menos compacto constituyendo el gradiente de valores ya indicado, lo que incluso permite (si bajamos el nivel de confianza al 95\%) dividirlo en dos subgrupos: El primero (formado por 4.07, $4.16,4.18,4.20$ y 4.21 ) con un radio medio de $31,1 \mathrm{~cm}$ tras 5 días; y el resto (21 
transformantes) con un radio medio de 24,7 $\mathrm{cm}$ tras 5 días. Estos transformantes, tanto considerándolos un solo grupo como dos subgrupos, se diferencian estadísticamente del aislado silvestre $(P<0,001 ; F$-test $=41,14)$.

\subsubsection{3 - Crecimiento en distintos medios de cultivo} de los tranformantes silenciados de $F$. oxysporum f.sp. phaseoli

Se realizó un análisis de crecimiento en distintos tipos de medios con una selección de los transformantes fuertemente silenciados. A tal fin se utilizaron los siguientes medios en los que se modificaron la fuente de carbono, nitrógeno o el pH: medio sintético sin glucosa (SM-Glu), medio sintético sin nitrógeno (SM-N), medio sintético a pH 4 (SM-4), medio sintético a pH 6 (SM-6), medio sintético a $\mathrm{pH} 8$ (SM-8), medio sintético con $\mathrm{NaNO}_{3}\left(\mathrm{SMNaNO}_{3}\right)$ como fuente de nitrógeno y medio sintético con $\mathrm{NaNO}_{2}$ (SMNaNO2) como fuente de nitrógeno.

Observamos diferencias entre algunos transformantes silenciados y las estirpes tipo silvestre usadas como control (SP01 y SP13) tras un periodo de crecimiento de tres días (Figura 4. 44 - Pág. 128) pero se hacen menos evidentes tras tiempos mayores, como una semana (Figura 4. 45 - Pág. 129).

Un análisis de la varianza (One-way ANOVA) comparando el grupo compuesto por los transformantes silenciados con el grupo formado por las estirpes silvestre SP1 y SP13 no evidencia ninguna diferencia significativa tras 7 días en ninguno de los medios. En cambio, si obtenemos diferencias significativas entre transformantes y estirpes silvestres en tres medios tras 3 días. Al cabo de una semana, las diferencias entre los transformantes y los tipos silvestres tienden a igualarse.

Existe una diferencia $(\mathrm{P}=0,036$; $\mathrm{F}$ test $=5,3$ ) en medio sin glucosa entre los transformantes silenciados $y$ las estirpes silvestres SP01 y SP13.

La mayor diferencia ( $P=0,00018$; Ftest=24,36) entre el grupo de transformantes silenciados y las estirpes silvestres se observa en medio ácido a $\mathrm{pH}$ 4. La tasa de crecimiento de las estirpes silvestres se hace menor según aumenta el $\mathrm{pH}$ del medio. Los radios de las colonias de las estirpes silvestres en medio a $\mathrm{pH} 4(13,5 \mathrm{~cm})$ y $\mathrm{pH} 8$ $(7,5 \mathrm{~cm})$ son diferentes $(P=0,062)$. Estas diferencias no se aprecian en los transformantes silenciados $(P=0,84)$, cuyo crecimiento es similar independientemente del $\mathrm{pH}$ del medio. Por ello, la separación entre transformantes y estirpes silvestres que vemos a $\mathrm{pH} 4$ no existe en los medios a pH 6 y $\mathrm{pH} 8$.

El último medio en el que se aprecian diferencias con significación estadística, es en medio sin nitrógeno (tras 3 días). El grupo de los transformantes silenciados se diferencia de los aislados del tipo silvestre SP13 y SP01 ( $P=0,036$; F-test=5,28). 


\subsubsection{4 - Alteración de la esporulación}

Se hicieron dos experimentos independientes en los que se ha calculado el número de esporas por mililitro tras 36 horas ○ 72 horas de cultivo en medio líquido (Figura 4. 41 - Pág. 125).

Las conclusiones fueron similares para los dos experimentos, pues los valores relativos entre un transformante y su tipo silvestre se mantienen similares en los dos experimentos independientes. Algunos transformantes muestran una reducción de la esporulación muy clara con respecto a su tipo silvestre, como 1.05 y 1.09 respecto a SP13 o $3.01,3,14,3.17$ y 3,18 respecto a
SP4. En otros casos existe una reducción menor, como 1.06 respecto a SP13. Y en otros casos o no observa reducción, o incluso la esporulación en el transformante es mayor que el tipo silvestre, como 3.15 y 3.19 respecto a SP4.

Eso hace que cuando agrupamos los transformantes que derivan de la misma estirpe silvestre y lo comparamos con ese tipo silvestre, en ningún caso encontremos significación estadística (en todos ellos $P>0,0005)$.

En resumen, la alteración es característica de cada aislado, existiendo transformantes claramente afectados en su capacidad de esporular.

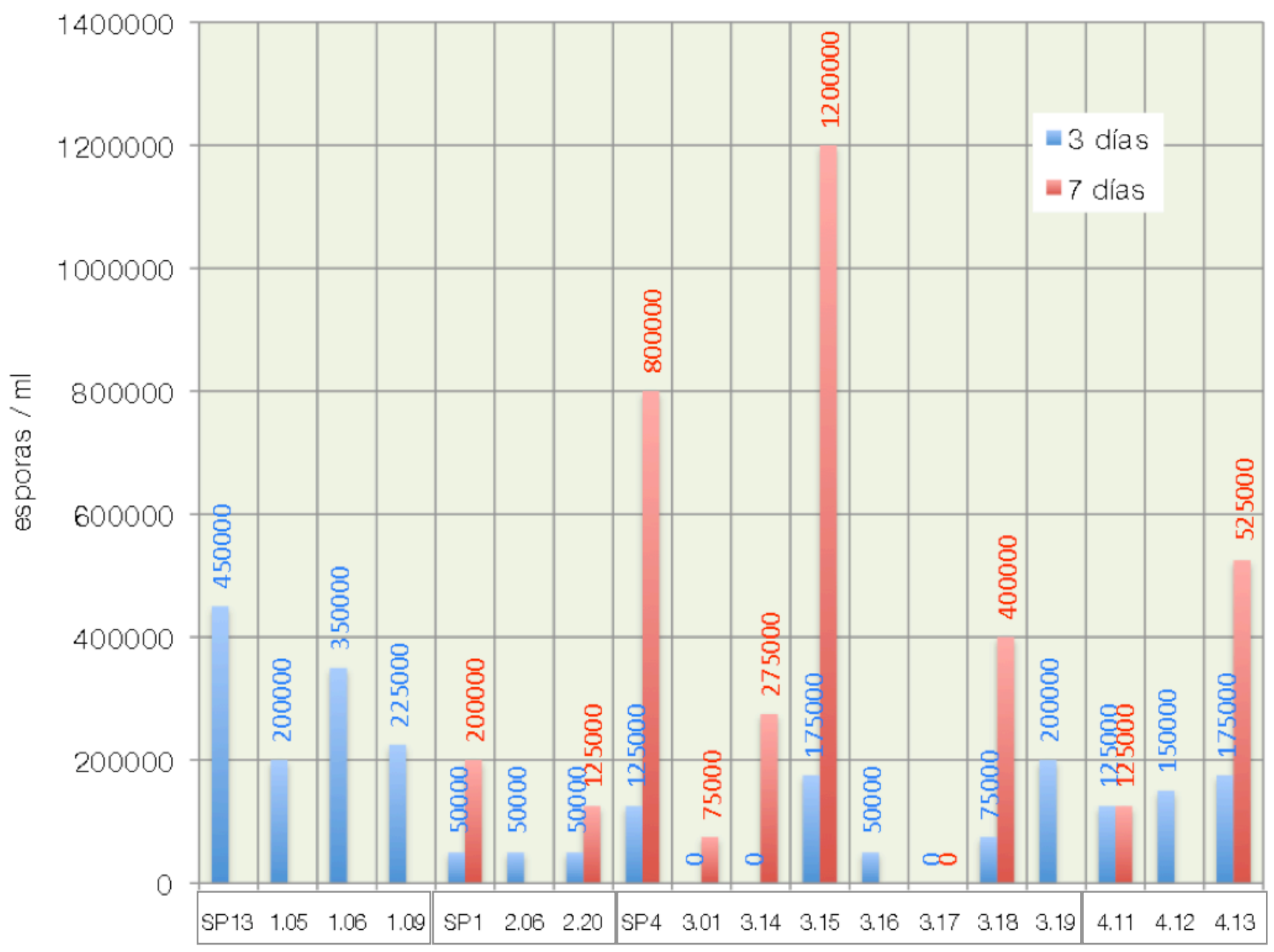

Figura 4. 41 - Tasa de esporulación (en esporas por mililitro) de varios transformantes frente a las estirpes silvestres de las que derivan, tras 3 días (azul) y 7 días (rojo) en cultivo líquido (PDB). 


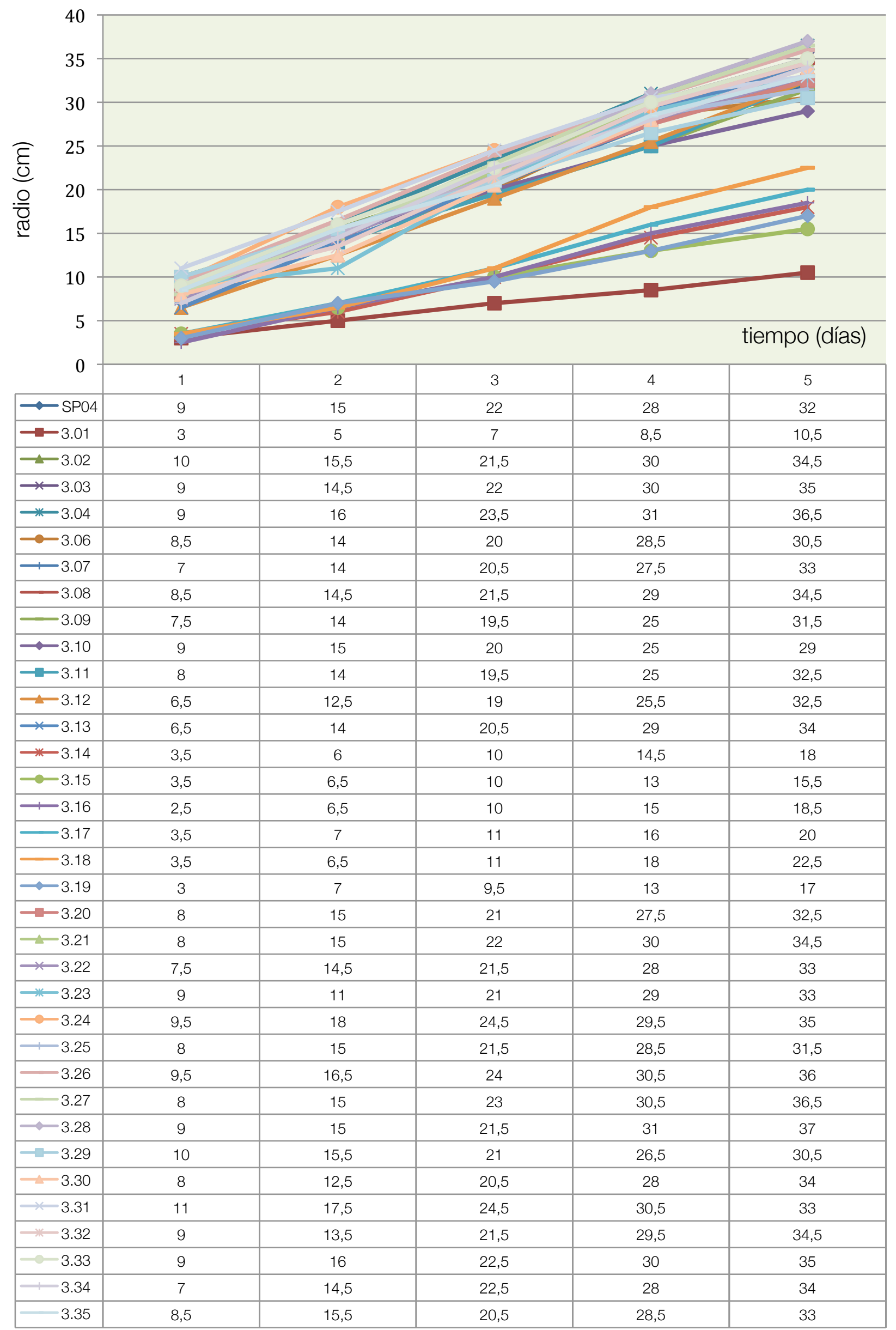

Figura 4. 42 - Crecimiento en medio PDA de la estirpe débilmente virulenta (SP4) y sus transformantes (3.XX). 


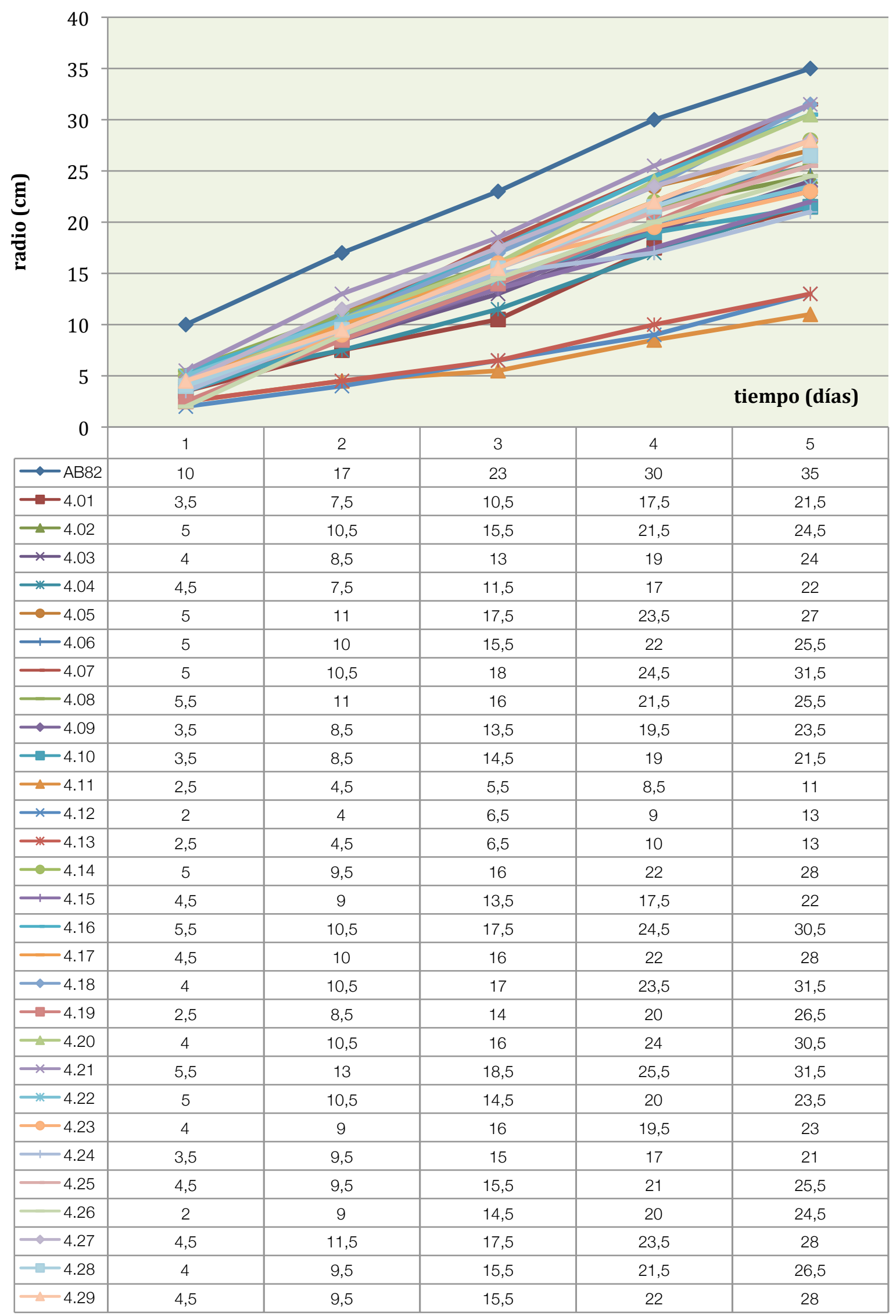

Figura 4. 43 - Crecimiento en medio PDA de la estirpe no patógena AB82 y sus transformantes (4.XX). 


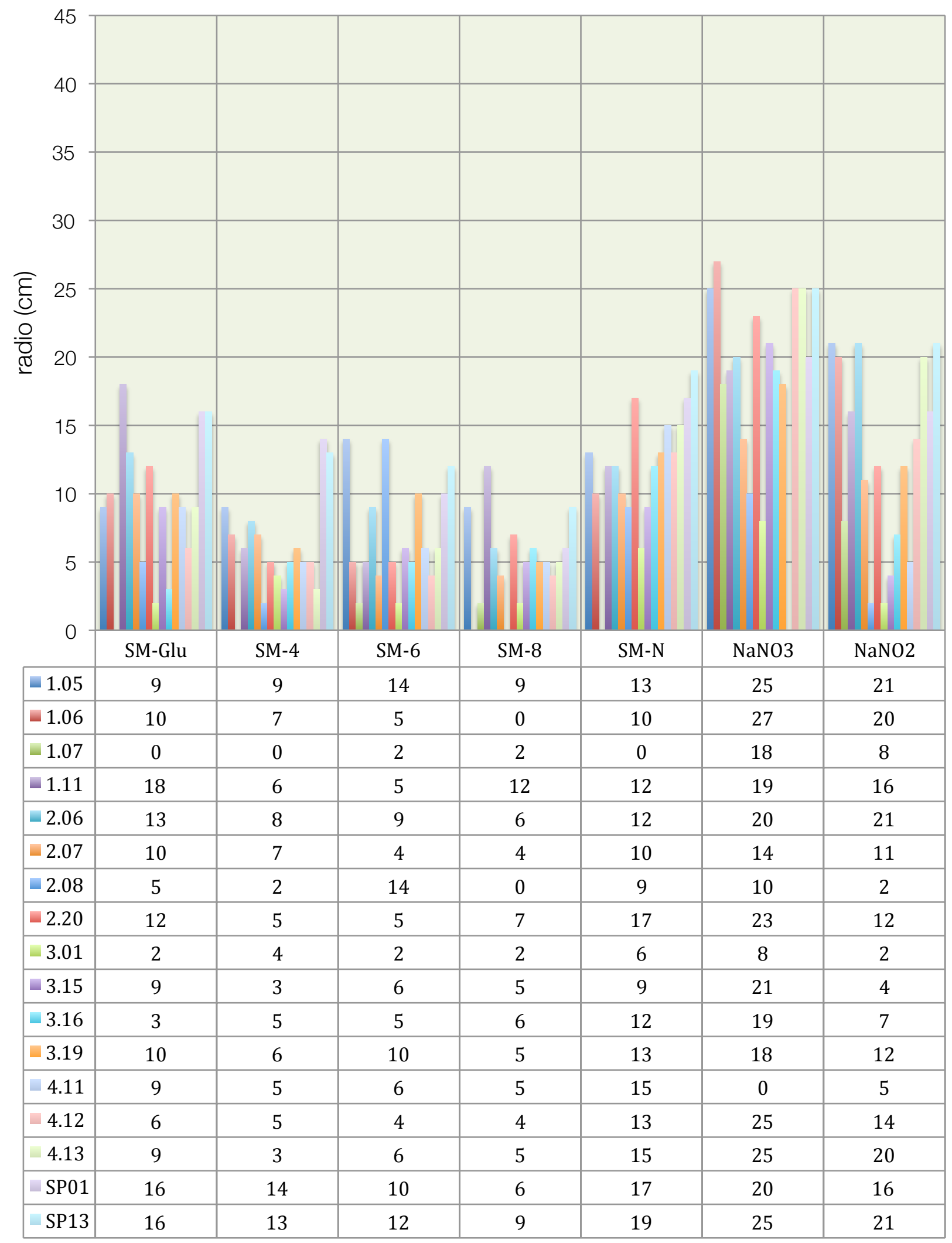

Figura 4. 44 - Crecimiento a los 3 días de una selección de aislados silvestres y transformantes silenciados en medios selectivos. SM-Glu: Sin glucosa. SM-(4|6|8): pH 4, 6 ó 8. SM-N: Sin fuente de nitrógeno. $\mathrm{NaNO}_{3}$ : Fuente de nitrógeno nitrato. $\mathrm{NaNO}_{2}$ : Fuente de nitrógeno nitrito. 


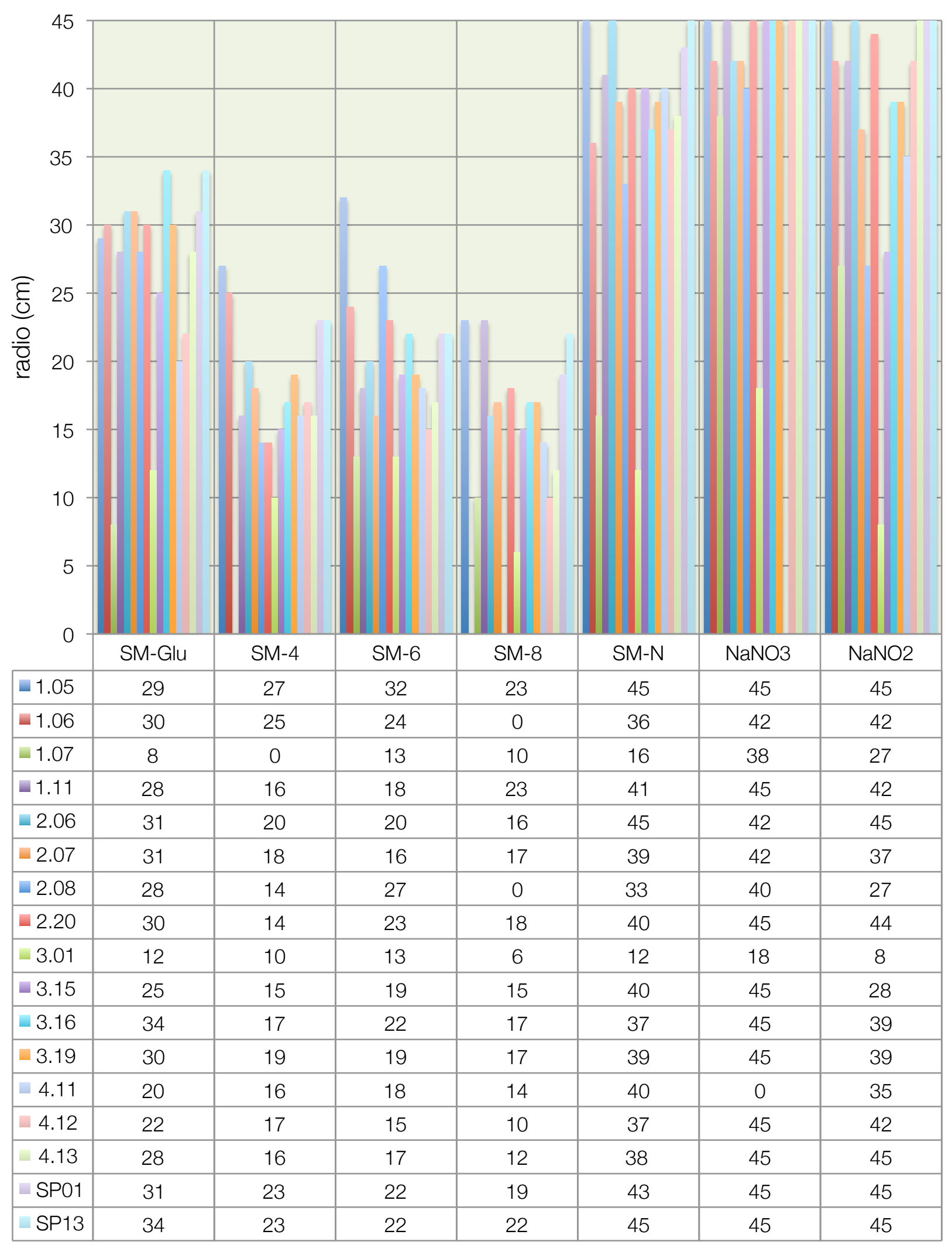

Figura 4. 45 - Crecimiento a los 7 días de una selección de aislados silvestres y transformantes silenciados en medios selectivos. SM-Glu: Sin glucosa. SM-(4|6|8): pH 4, 6 ó 8. SM-N: Sin fuente de nitrógeno. $\mathrm{NaNO}_{3}$ : Fuente de nitrógeno nitrato. $\mathrm{NaNO}_{2}$ : Fuente de nitrógeno nitrito. 
4.4.4 - Análisis de la virulencia en los

transformantes silenciados

\subsubsection{1 - Virulencia en transformantes silenciados} en $f t f$

Las estirpes débilmente virulentas, como SP4, tienen una copia del gen $f t f 2$ pero ninguna del gen ftf1. Para comprobar si el silenciamiento del gen ftf2 tiene efectos sobre la virulencia se realizó un ensayo en plantas de judía variedad "Blanca-Riñon" con el aislado SP4 y un conjunto de transformantes silenciados derivados de SP4. Se eligieron transformantes que habían mostrado distintos niveles de alteración del crecimiento, aunque se priorizaron los que mostraban una mayor reducción de la tasa de crecimiento.

Como se observa en la fotografía del desarrollo del ensayo a las dos semanas (Figura 4. 47 - Pág 130) el porte y salud de las plantas es muy parecido entre todos los aislados. En detalle, se observan lesiones localizadas en todos los grupos.

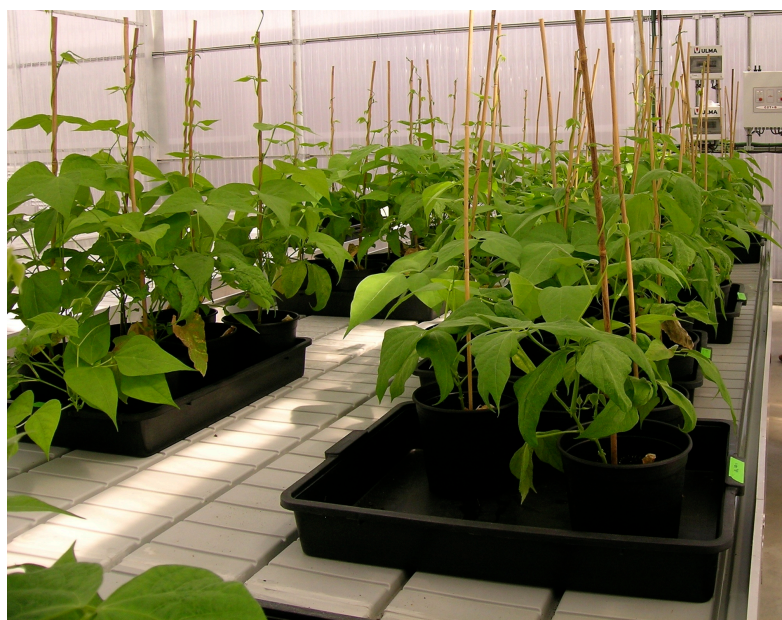

Figura 4. 47 - Vista general de un ensayo de infección en plantas de judía tras dos semanas infectadas con aislados débilmente virulentos.
Si la planta consigue sobrevivir las primeras dos o tres semanas y alcanzar un buen desarrollo, los aislados débilmente virulentos se han mostrado incapaces de progresar en nuestros ensayos realizados en invernadero.

Medimos la virulencia en la escala CIAT tras 4 semanas, momento a partir del cual los valores se estabilizan en el tiempo. La estirpe del tipo silvestre débilmente virulenta SP4 (escala CIAT \pm StdDesv = $6,5 \pm 2,05)$ no se diferencia $(P=0,609 ; \quad F-$ test=0,29) del grupo formado por los transformantes $3.01(7,5 \pm 1,5), 3.14(5,8 \pm 2,6)$, $3.15(6,3 \pm 3,0), 3.16(5,7 \pm 2,7), 3.18(5.0 \pm 2,6)$ y $3.19(6,5 \pm 0,8)$. El valor de virulencia usando la escala CIAT de la estirpe SP4 es similar al obtenido en ensayos anteriores (Alves-Santos et al., 2002) con la misma variedad de judía: $6,8 \pm 1,1$.

En resumen, no se observaron diferencias entre los aislados silenciados y el tipo silvestre SP4. En ambos casos, en algunas de las plantas de la tanda aparecían lesiones y la caída de hojas que apuntan a que la infección se estaba desarrollando.

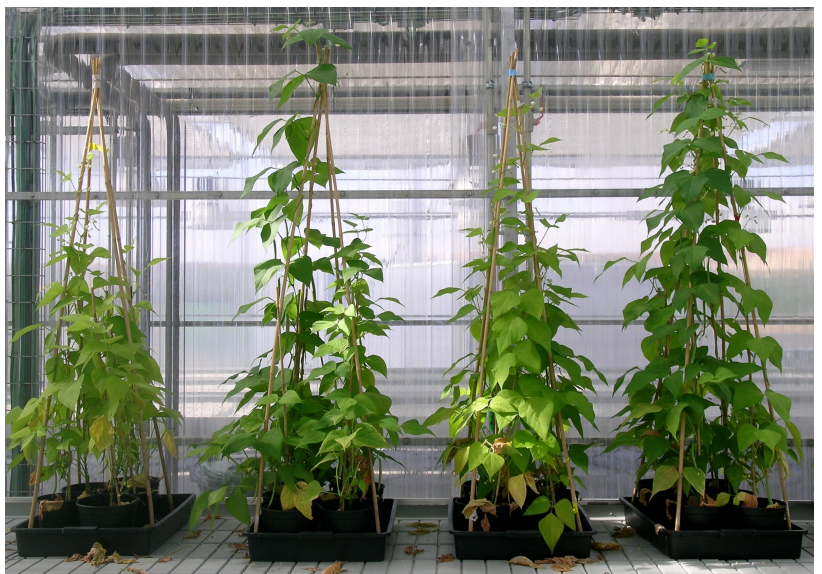

Figura 4. 46 - Plantas de judía tras seis semanas infectadas con (de izq. a der.) 3.15, 3.01, SP4 y SP4 (repetida). 
4.4.4.2 - Virulencia en transformantes silenciados en ftf1 y ftf2

Los aislados supervirulentos y altamente virulentos presentan cinco y cuatro copias del gen $f t f 1$, respectivamente, además de la copia única del gen ftf2. Se realizaron ensayos de patogenicidad en invernadero inoculando 10 plantas de judía en cada ronda con transformantes silenciados, y se compararon los síntomas de la enfermedad con aquellos inducidos por las estirpes silvestres de las que derivan. El ensayo con cada estirpe fue repetido una vez, para hacer un total de al menos 20 plantas.

En el caso de los aislados supervirulentos, se comparó el avance de la enfermedad vascular (medida en la escala
CIAT) entre el aislado silvestre SP13 y seis transformantes silenciados que habían mostrado una alteración del crecimiento clara: $1.04,1.05,1.06,1.07,1.09$ y 1.11. Los resultados (Figura 4. 48 - Pág. 131) fueron variables según el transformante. Dos de los transformantes, 1.05 y 1.07 , no muestra diferencias en el resultado final con el tipo silvestre pero la evolución es más lenta. Dos de los aislados, 1.06 y 1.09, mostraron un avance de la enfermedad más lento en las dos primeras semanas pero en la tercera y cuarta semanas mostraban valores en la escala CIAT entorno a 7 , si bien no alcanzaron los niveles de la estirpe silvestre. En estos cuatro transformantes, su comportamiento más lento muestra más similitudes con el desarrollo de la enfermedad

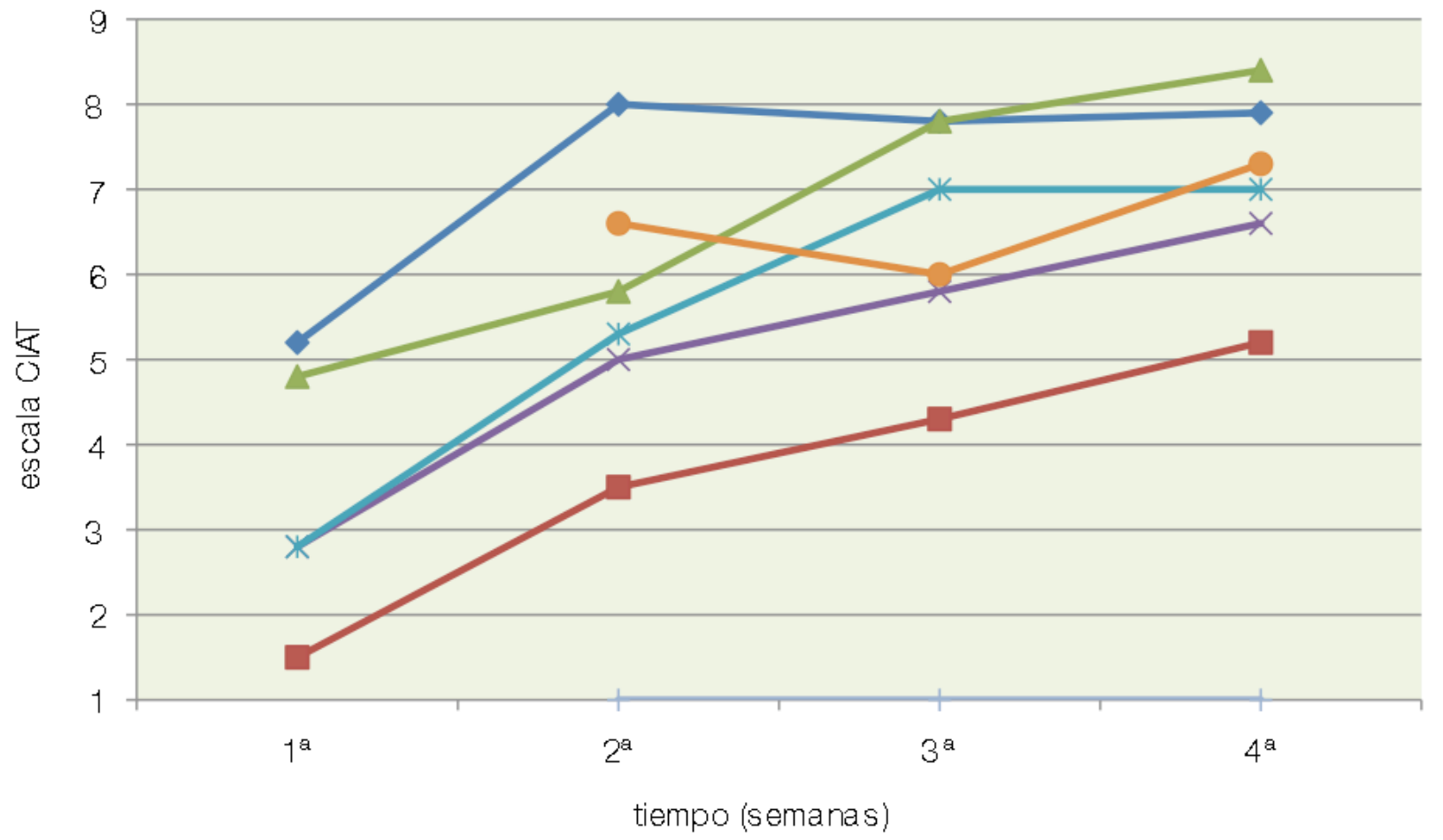

$\multimap$ SP13 $-1.04 \div-1.05 \div 1.06 \div-1.07-1.09 \div 1.11$

Figura 4. 48 - Progreso de la enfermedad, cuantificado mediante índice CIAT, en planta de judía de la variedad Blanca-Riñon inoculadas con esporas de la estirpe silvestre FOP-SP13 y varios transformantes silenciados. 
en un altamente virulento que con un supervirulento, como se observa (Figura 4. 50 - Pág. 135) en las fotografías de la tercera semana, SP13 prácticamente ha matado la mayor parte de las plantas y los transformantes no, siendo especialmente claro en 1.06 y 1.09 .

El transformante 1.04 mostró variaciones claras mostrando una menor sintomatología desde la primera semanas, lo que permitió a las plantas crecer más, lo que a su vez conllevó diferencias aún más claras en las siguientes semanas con valores en la escala CIAT entorno a 5.

Como se observa en la primera fila de la fotografía del ensayo a las cinco semanas (Figura 4. 52 - Pág. 136) la comparación entre el estado de las plantas infectadas con SP13 y 1.04 muestra una clara diferencia: En ambos casos existe una sintomatología externa muy clara pero las plantas siguen vivas en un caso y no en el otro.

Cuando inoculamos plantas de judía con el transformante silenciado 1.11, no obtuvimos desarrollo de la enfermedad en ninguno de los ensayos de infección, y valores en la escale CIAT de 1. Como se observa en la fotografía a las tres semanas tras la infección (Figura 4. 50 - Pág. 135), el transformante 1.11 no muestra diferencias con el control negativo.

También se ha comparado la virulencia del aislado altamente virulento SP1 y los transformantes silenciados derivados del mismo. Al igual que en caso anterior, tres de los transformantes $(2.06,2.07$ y 2.20$)$ no mostraron variaciones con el tipo silvestre, con valores en la escala CIAT por encima de 7, alguno mayor que el tipo silvestre. En el caso de 2.07, en la segunda semana mostraba una diferencia en su valor en la escala CIAT $(6,5)$ apreciable con respecto a la

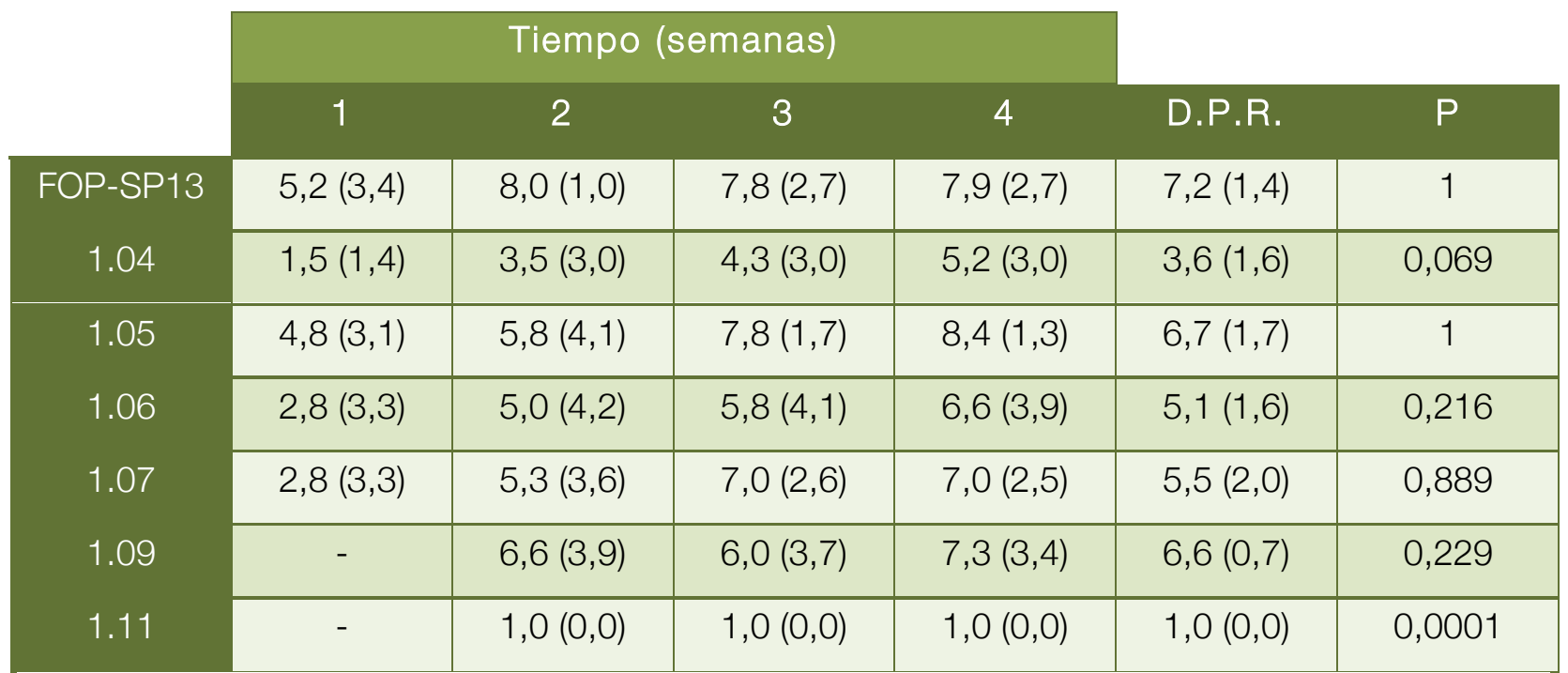

Tabla 4. 14 - Valores de virulencia de los aislados supervirulentos, medidos en la escala CIAT y vía el parámetro D.P.R. en judía. El valor en cada celda representa el valor medio de la escala CIAT de todas las plantas para el aislado en esa semana. El valor entre paréntesis es la desviación de dicho valor medio. D.P.R.: Velocidad de progresión de la enfermedad. P: Valor crítico del Análisis de la Varianza (One-way ANOVA) con respecto SP13 para los valores CIAT de la tercera semana. 
estirpe silvestre (8,3). En el caso de 2.20, los resultados obtenidos deben tomarse con cautela por su anormalidad.

Sin embargo, el aislado 2.08 muestra una evolución de la enfermedad más lenta y al cabo de cinco semanas se pudieron observar diferencias con el tipo silvestre (Figura 4. 52 - Pág. 136). En ambos aislados, todas plantas habían desarrollado la enfermedad, pero las plantas infectados con 2.08 se mostraban más sanas. Sus valores en la escala CIAT son mucho menores que los de la estirpe silvestre a todos los tiempos.

Para comprobar la significación estadística usamos los valores D.P.R. (Disease progression rate) y el valor crítico $(\mathrm{P})$ del análisis de la varianza (One-way ANOVA) tanto en los aislados supervirulentos (Tabla 4.
15 - Pág. 134), como aislados altamente virulentos (Tabla 4. 15 - Pág. 134).

El análisis estadístico utilizando los valores D.P.R. permite establecer tres grupos de virulencia: la estirpe silvestre SP13 $(7,2 \pm 1,4)$, los cuatro transformantes silenciados $1.05(6,7 \pm 1,7), 1.06(5,1 \pm 1,6), 1.07$ $(5,5 \pm 2,0)$ y $1.09 \quad(6,6 \pm 0,7) ; \quad$ y $\quad$ los transformantes fuertemente silenciados 1.04 $(3,6 \pm 1,6)$ y $1.11(1,0 \pm 0,0)$.

El valor D.P.R. de los aislados altamente virulentos no muestra esa diferencia clara entre la estirpe silvestre SP01 $(7,1 \pm 2,1)$ y los transformantes silenciados $2.06(7,4 \pm 3,3), 2.07(6,7 \pm 1,9)$ y $2.20(9,0 \pm 0,0)$. Diferencias que tampoco se apreciaban en las fotografías (Figura 4. 50). En cambio, el valor D.P.R. del transformante fuertemente

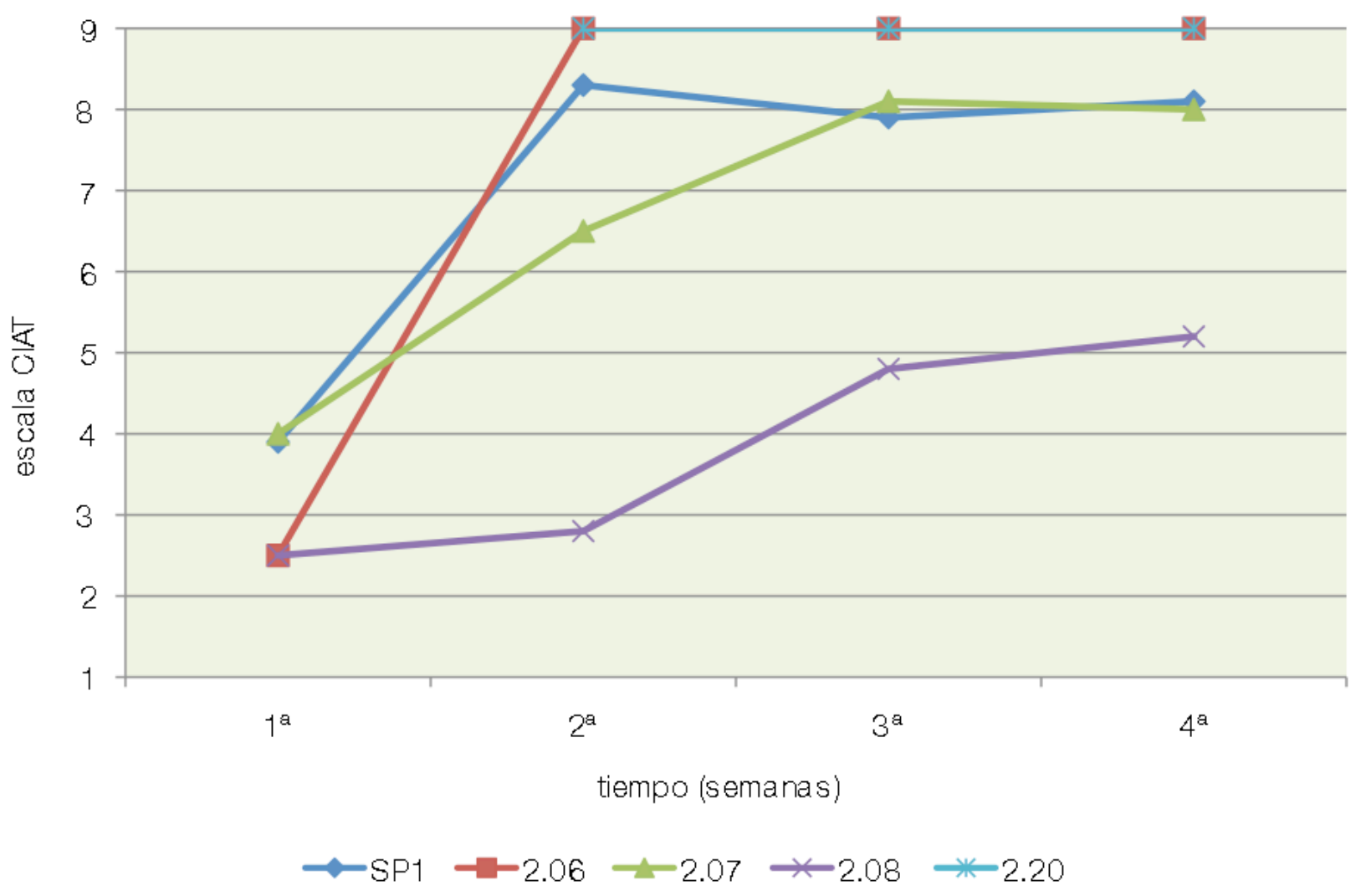

Figura 4. 49 - Progreso de la enfermedad, cuantificado mediante índice CIAT, en planta de judía de la variedad Blanca-Riñon inoculadas con esporas de la estirpe silvestre FOP-SP01 y varios transformantes silenciados. 
silenciado 2.08 si es diferente $(3,8 \pm 1,4)$, evidenciando las diferencias que también se apreciaban en las fotografías (Figura 4. 52).

En resumen, la relación entre lo observado en las fotografías y el valor D.P.R. lo hacen muy adecuado para cuantificar la virulencia.

También realizamos un Análisis de la Varianza (One-way ANOVA) entre el valor de la escala CIAT a las tres semanas del conjunto de plantas infectadas con cada transformante silenciado en relación con las plantas infectadas con su respectiva estirpe silvestre, en los aislados supervirulentos (Tabla 4. 15 - Pág. 134) y aislados altamente virulentos (Tabla 4. 15 - Pág. 134). Solo en el caso de 1.11 (que no mostraba sintomatología alguna) se obtiene un nivel de confianza significativo $(P<0,0001)$. Los altos valores de desviación estandar característicos de los ensayos en planta dificultan enormemente la validación de las observaciones mediante ANOVA mientras no se aumente críticamente la población de plantas infectadas.

Cuando obtuvimos las construcciones de silenciamiento en F. oxysporum f.sp. lycopersici, realizamos un ensayo de virulencia comparando un aislado silvestre Fol-Strainl con el transformante silenciado W4 derivado del mismo y que había mostrado reducción en el crecimiento en placa.

Cuando se comparan las plantas infectadas con uno y otro aislado existen evidencias claras de una diferencia en el crecimiento (Figura 4. 51 - Pág. 136): las plantas infectadas con el tipo silvestre aunque no muestran una sintomatología externa tan evidente como las plantas de judía, si muestran un menor porte o altura (una media de $30 \mathrm{~cm}$ ) que las infectadas con el transformante (una media de $15 \mathrm{~cm}$ ) tras tres semanas de infección.

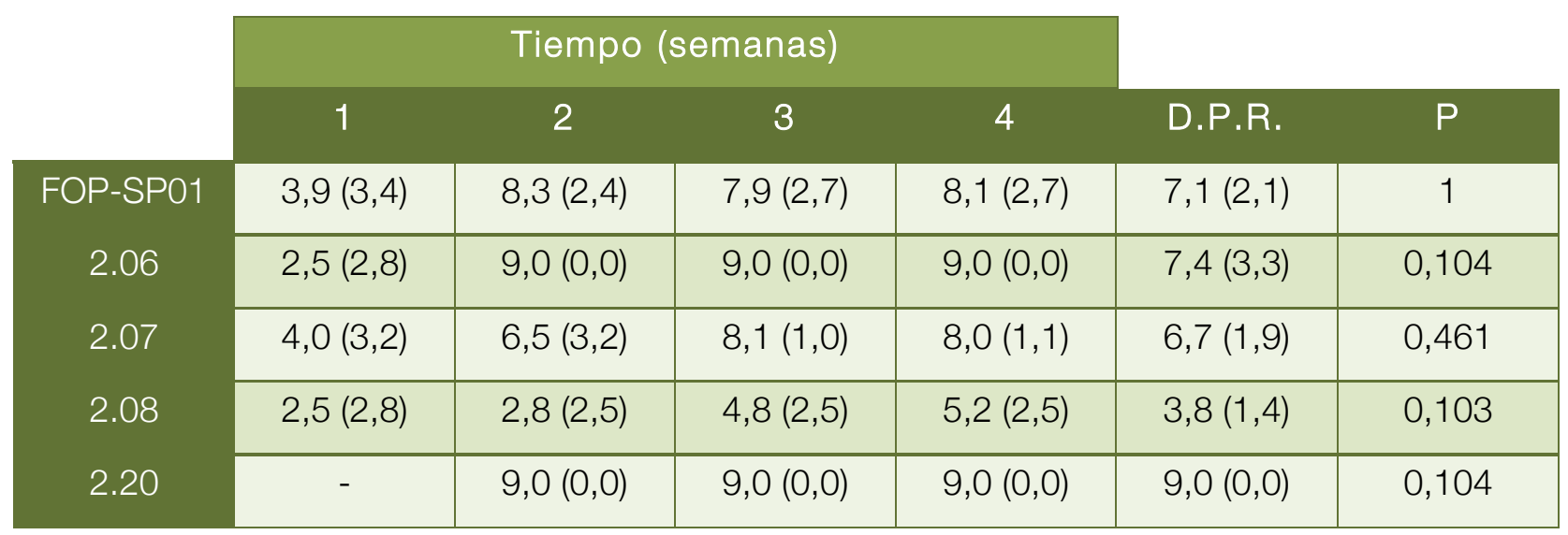

Tabla 4. 15 - Valores de virulencia de los aislados altamente virulentos, medidos en la escala CIAT y vía el parámetro D.P.R. en judía. El valor en cada celda representa el valor medio de la escala CIAT de todas las plantas para el aislado en esa semana. El valor entre paréntesis es la desviación de dicho valor medio. D.P.R.: Velocidad de progresión de la enfermedad. P: Valor crítico del Análisis de la Varianza (One-way ANOVA) con respecto SP01 para los valores CIAT de la tercera semana. 


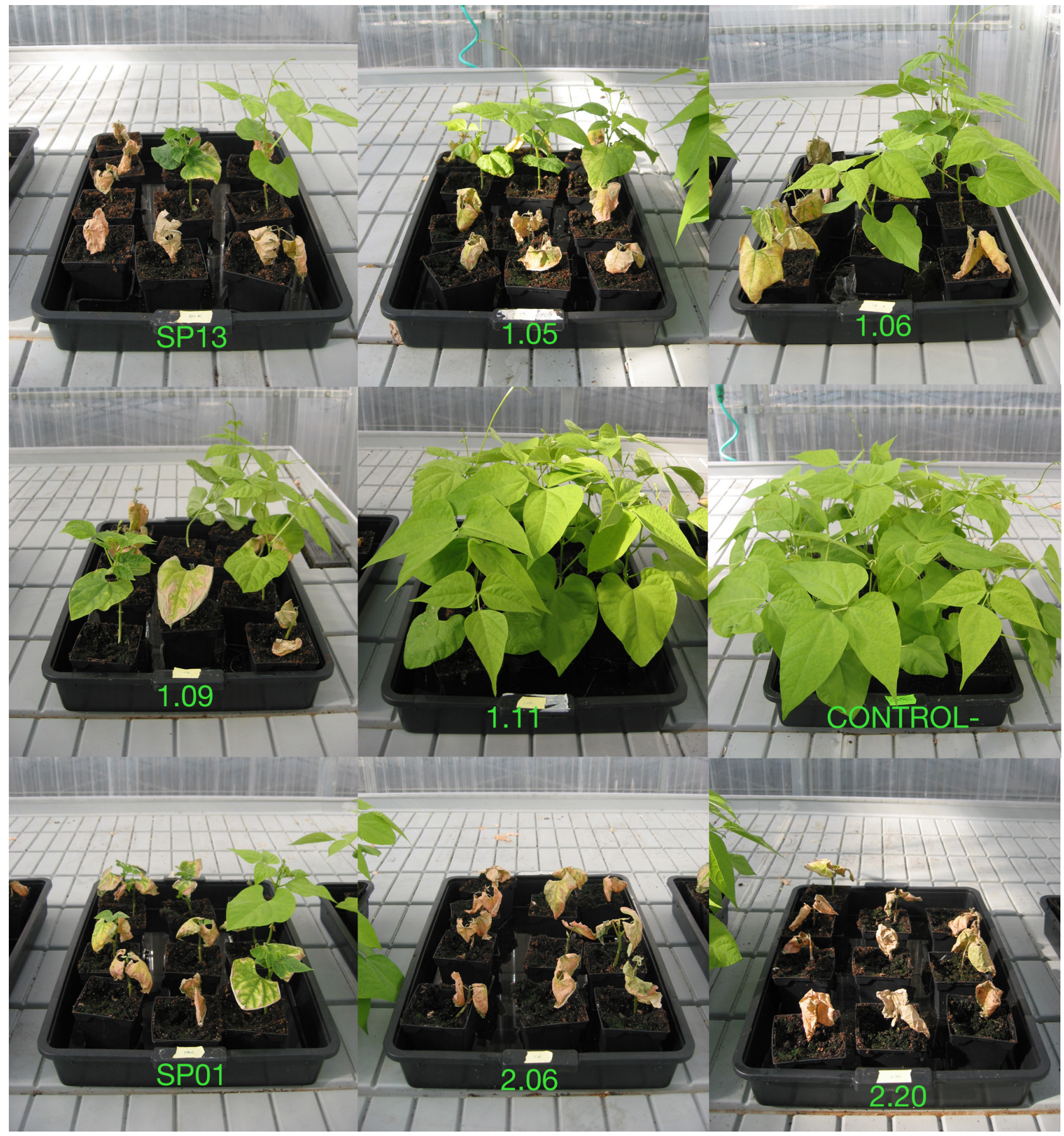

Figura 4. 50 - Ensayo de virulencia a las 3 semanas tras la infección en una selección de estirpes silvestres y silenciadas. 


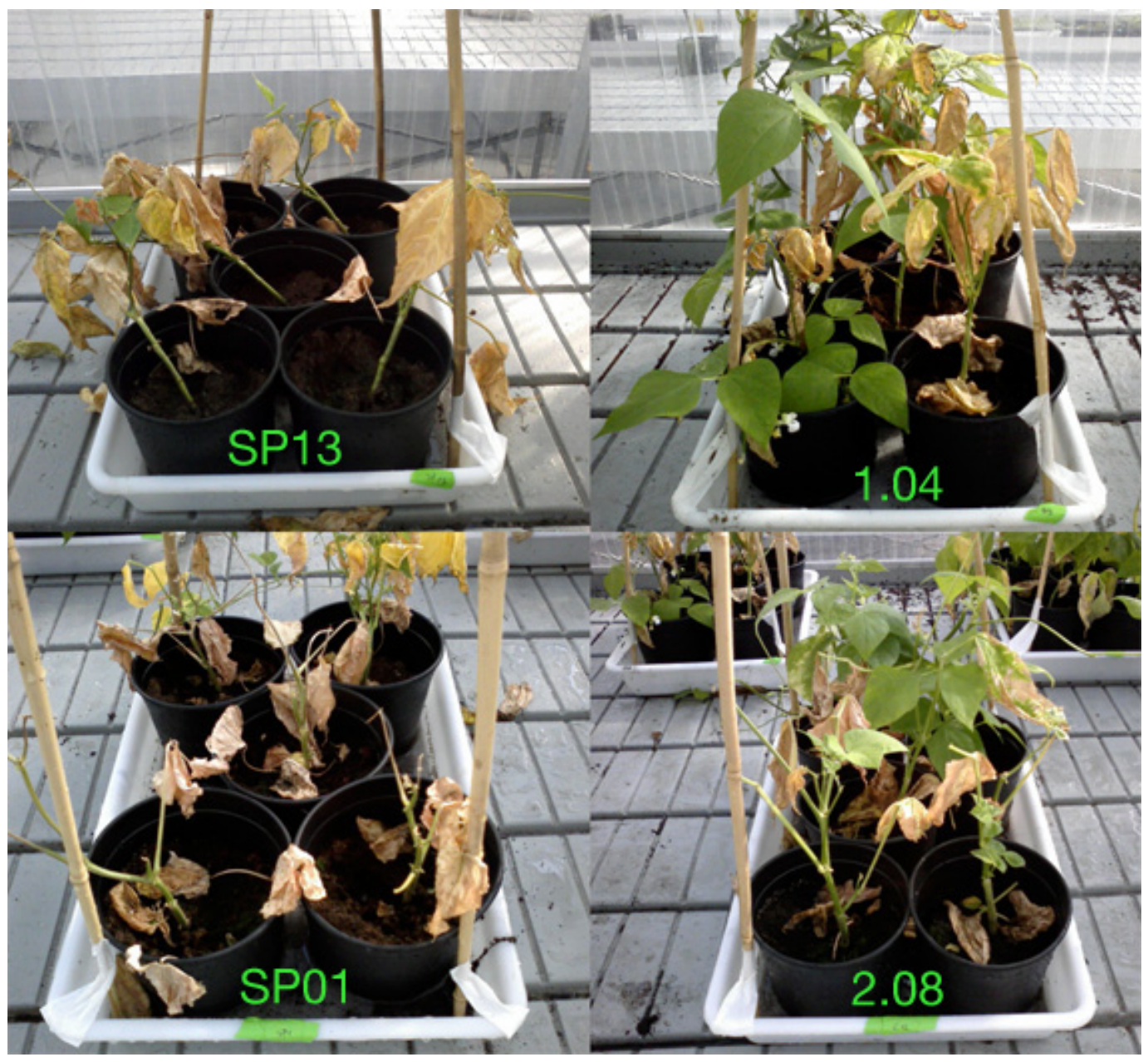

Figura 4. 52 - Ensayo de virulencia a las cinco semanas. Comparación de las estirpes tipo silvestre SP13 y SP01, con los transformantes silenciados que muestran una más clara reducción de la virulencia: 1.04 y 2.08 .

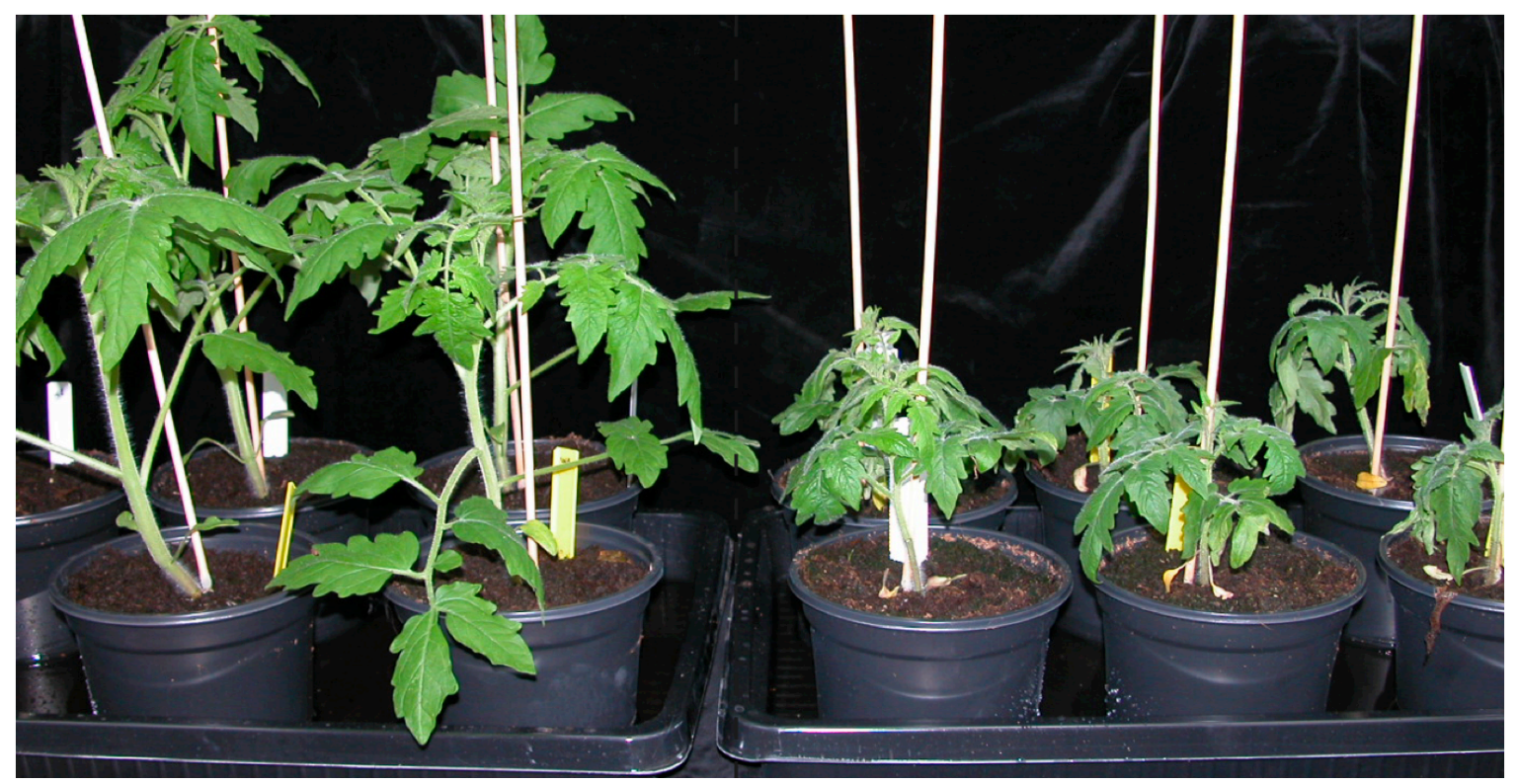

Figura 4. 51 - Ensayo de virulencia en plantas de tomate infectadas con el transformante W4 (izq.) y la estirpe silvestre Fol-Strain I (der.) tras tres semanas desde la infección. 


\section{5 - Genes regulados por ftf2}

\subsection{1 - Hibridación substractiva}

Los factores de transcripción como ftf2 están normalmente implicados en regulación. Esto hace muy interesante intentar averiguar los genes que están regulados por el mismo. Solo conociendo los genes relacionados con ftf2 estaremos en condiciones de averiguar inequívocamente su función biológica.

Al disponer de transformantes silenciados en ftf2 nos planteamos la posibilidad de comparar los transcritos de estos con el del correspondiente tipo silvestre con expresión normal. Como hemos caracterizado estirpes silvestres de $F$. oxysporum f.sp. phaseoli débilmente virulentas y sin presencia de $f t f 1$, las variaciones observadas se deberán exclusivamente al silenciamiento de ftf2.

Para ello construimos una librería de secuencias expresadas diferencialmente entre ambos tipos de estirpes, silenciadas en ftf2 y no silenciadas, que posteriormente verificamos mediante PCR en tiempo real en diferentes condiciones.

\subsubsection{1 - Comparación entre SP4 y 3.01 a las 24} horas

La genoteca de transcritos diferenciales se construyó a partir de ARN poliA+ obtenido a las 24 horas de cultivo en medio líquido (PDB) del aislado débilmente

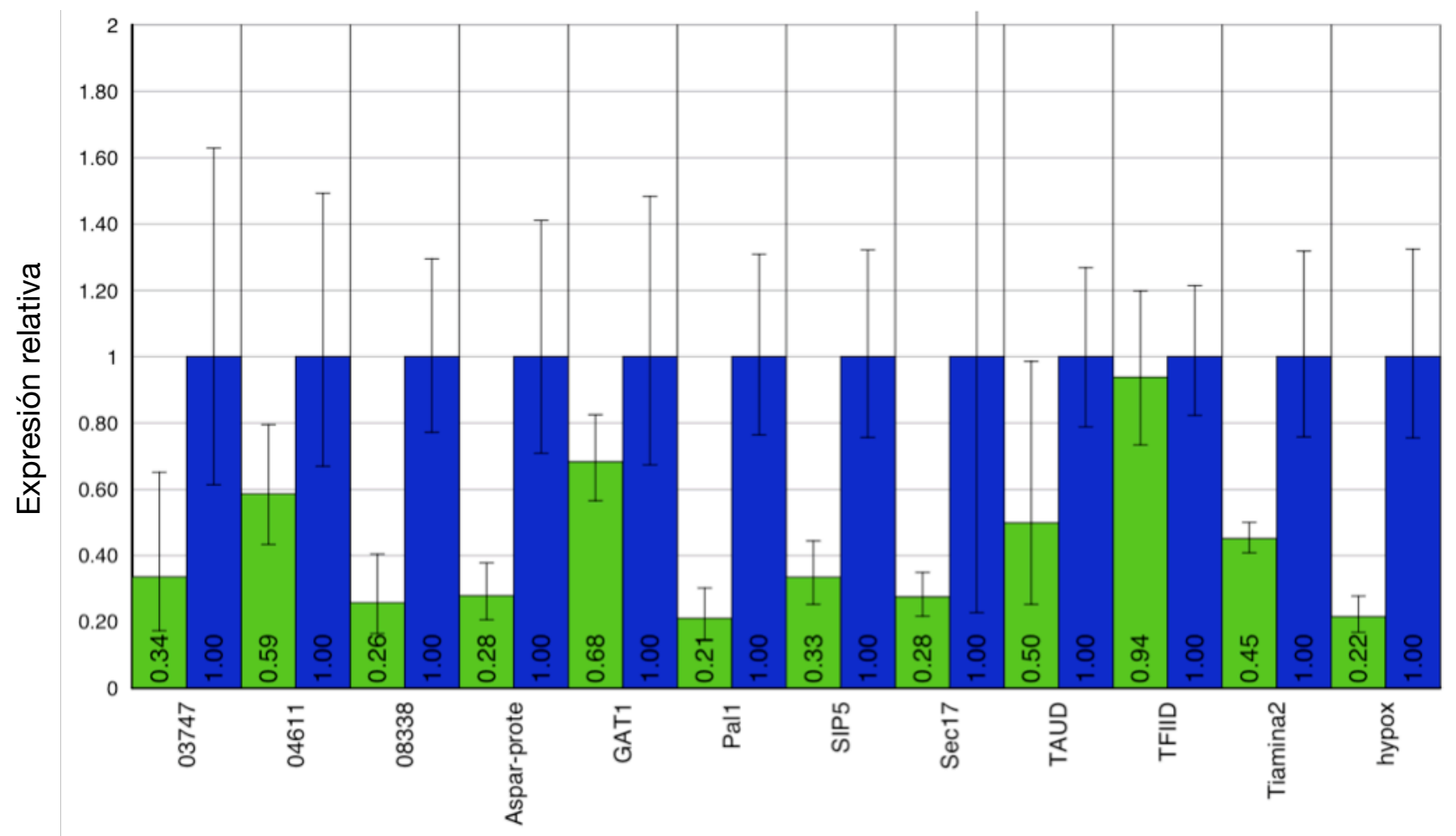

Figura 4. 53 - Expresión relativa de los genes diferencialmente expresados entre el transformante 3.15 (verde) y el aislado silvestre SP4 (azul) tras 24 horas en cultivo. 
virulento SP4 y el transformante 3.01, que es el que ha mostrado un fenotipo de crecimiento más afectado, y por tanto el más fuertemente silenciado.

Se secuenciaron 60 clones, de los que se descartaron 14 por ser ilegibles, no contener inserto o ser secuencias de ARN ribosómico. De los 46 restantes se obtuvieron 18 secuencias parciales diferentes.

La representatividad en la genoteca diferencial es directamente proporcional al grado de presencia o ausencia en uno de los transcritos con respecto al otro transcrito, y no de la cantidad absoluta de transcrito existente en ellos.

Estas secuencias parciales se compararon con la base de datos del proyecto de secuenciación de Fusarium oxysporum (Broad Institute. MIT, EE.UU.), con el fin de identificar las ORFs completas..

Tras un análisis preliminar de las secuencias y según su representación en la genoteca, seleccionamos para un estudio más profundo doce que constituyen ORFs cuya función teórica parece más interesantes para aclarar el papel de ftf2 (Tabla 4. 16 Pág. 72). Cada uno de estos ORFs se identificó con un código.

\subsubsection{2 - Expresión relativa de los genes de interés en otro transformante y a distinto tiempo}

Una vez comprobada que las secuencias obtenidas estaban presentes en el genoma secuenciado de F. oxysporum, se verificó que estos genes realmente se expresan en distinto grado en el aislado silvestre y el transformante fuertemente

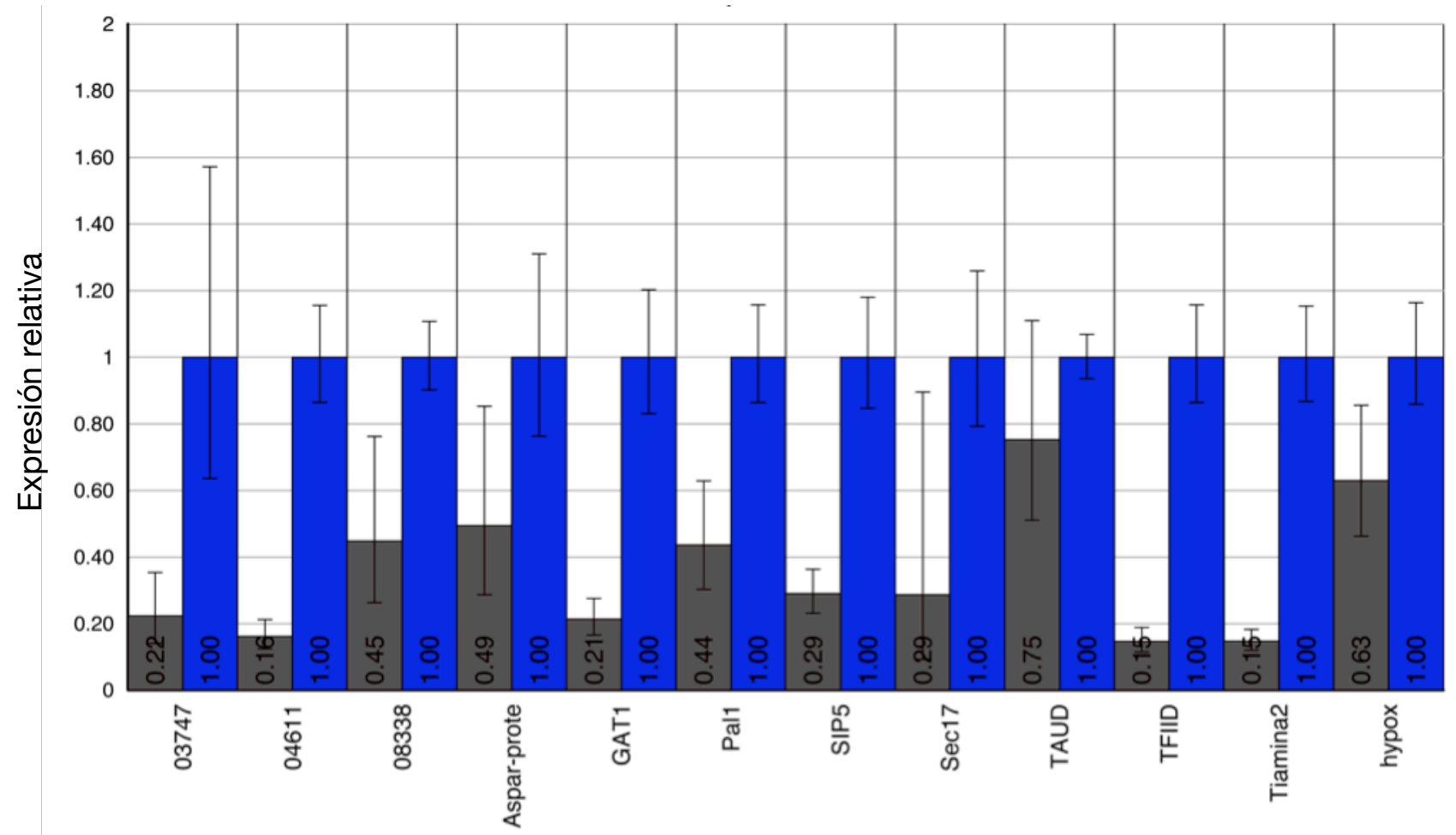

Figura 4. 54 - Expresión relativa de los genes diferencialmente expresados entre el transformante 3.01 (gris) y el aislado silvestre SP4 (azul) tras 48 horas en cultivo. 
silenciado. Así mismo, es de interés comprobar que esa expresión diferencial sucede también en otros transformantes silenciados en ftf2, además de comprobar qué sucedía con la expresión a un tiempo superior a las 24 horas. Con ese fin, se comparó la expresión relativa de los 12 genes seleccionados en el tipo silvestre SP4 y el transformante 3.15 , a las 24 horas, esto es, el mismo tiempo pero distinto transformante. $Y$ de igual forma, se procedió a comparar la expresión relativa en el aislado silvestre SP4 y el transformante 3.01 a las 48 horas, es decir, los mismos aislados usados en la construcción de la genoteca pero a las 48 horas.

Todos los genes estudiados presentaron una menor expresión en los transformantes silenciados que en el aislado silvestre. En el caso del transformante 3.15 a las 24 horas (Figura 4. 53 - Pág. 72) la expresión menor de los genes está en algunos casos clara, con valores entre el 20$30 \%$ (genes Pal1, SIP5 y hypox.) considerando como $100 \%$ la expresión en el aislado silvestre del respectivo gen, y en otros hay que tomarlos con mayor cautela, bien por la desviación o los valores medios del 68\% (gen GAT1) o 81\% (gen TFIID).

La expresión a $48 \quad \mathrm{~h} \quad \mathrm{del}$

\begin{tabular}{|c|c|c|c|c|c|}
\hline Código & Función hipotética & Clones & Fo & Fv & $\mathrm{Fg}$ \\
\hline 04611 & Desconocida & 7 & $x$ & $x$ & - \\
\hline GAT1 & Glutamino aminotransferasa tipo 1 & 5 & $X$ & $x$ & $x$ \\
\hline Tiamina & Piruvato descarboxilasa & 5 & $x$ & $x$ & $x$ \\
\hline Hypox & Respuesta a hipoxia mitocondrial & 4 & $x$ & $x$ & $x$ \\
\hline SIP5 & Regulación estrés nutricional & 3 & $x$ & $x$ & $x$ \\
\hline 08338 & Desconocida & 3 & $x$ & $x$ & - \\
\hline * & Ciclina & 3 & $x$ & $x$ & - \\
\hline Aspa-prote & Aspartil proteasa & 3 & $x$ & $x$ & $x$ \\
\hline TFIID & Regulación transcripción génica & 2 & $x$ & $x$ & $x$ \\
\hline * & Histona & 2 & $x$ & $x$ & $x$ \\
\hline 03747 & Desconocida & 2 & $x$ & $x$ & $x$ \\
\hline * & Metiltransferasa & 1 & $x$ & $x$ & - \\
\hline * & ETIF2: Regulación de la traducción & 1 & $x$ & - & $x$ \\
\hline * & Sui2: Regulación de la traducción & 1 & $X$ & $x$ & $X$ \\
\hline TauD & Catabolismo de la taurina (fuente de azufre) & 1 & $x$ & $x$ & - \\
\hline Pal1 & Morfología y crecimiento membrana celular & 1 & $x$ & $x$ & $x$ \\
\hline * & Proteína desconocida 13587 & 1 & $x$ & $X$ & - \\
\hline Sec17 & Transporte entre vesículas intracelulares & 1 & $x$ & $x$ & $x$ \\
\hline
\end{tabular}

Tabla 4. 16 - ORFs encontrados en la secuenciación de la genoteca de expresión diferencial. *: Descartada en el estudio de expresión relativa. Fo: $F$. oxysporum, Fv: $F$. verticilloides, Fg: F. graminearum (G. zeae). X: Presente, -: No presente. 
transformantes 3.01 (Figura 4. 54 - Pág. 72) presenta unas diferencias mucho mayores y los resultados son más claros, que los obtenidos a 24 horas. Estas diferencias se pueden deber al transformante analizado (3.01 muestra fenotipos más alterados que 3.15) y/o al distinto tiempo de cultivo (la expresión de ftf2 es menor a las 24 horas que a las 48 horas).

En este último estudio de expresión relativa, la mitad de los genes (03747, 04611, GAT1, SIP5, TFIID y Tiamina) mostraban reducciones considerables y mínimas desviaciones, con valores de expresión entorno a la tercera parte de la del tipo silvestre. Un segundo grupo mostraba mayores desviaciones y menores reducciones. La expresión de 08338, asparprote., Pal1 y TAUD son aproximadamente la mitad que el tipo silvestre. Un caso especial es el gen Sec17, que muestra una expresión reducida (la cuarta parte de la del tipo silvestre) en el transformante pero con una desviación considerable.

El gen hypox., que muestra una reducción clara en el transformante 3.15 a las 24 horas, por el contrario, presenta un nivel de expresión muy semejante al tipo silvestre a las 48 horas.

\subsection{2 - Análisis comparativo de los presuntos}

genes expresados diferencialmente

\subsubsection{1 - Proteina aspartil proteasa ("aspar-prote")}

Aparecen fragmentos de este gen en tres de los clones analizados y su expresión es claramente diferencial en los dos estudios de expresión relativa, siendo en el transformante 3.15 aproximadamente un $30 \%$ que en el aislado silvestre a las 24 horas, y entorno al 50\% del aislado silvestre en el transformante 3.01 a las 48 horas.

Existe una secuencia homóloga en la base de datos de transcritos de $F$. oxysporum (03555), F. verticilloides (02428) y $F$. graminearum (08842). En el caso de $F$. oxysporum f.sp. lycopersici se encuentra en el cromosoma 8 y presenta un marco de lectura de $1812 \mathrm{nt}$ (1712 nt sin intrones) que se traduce en una proteína de 516 aa.

El análisis de la secuencia proteica en las bases de datos de familias de dominios PFAM y NBCl-CDD revela la existencia de un dominio común en eucariotas del tipo aspartil proteasa, característico de enzimas proteolíticas $\mathrm{o}$ de hidrólisis de enlaces peptídicos de mamíferos, levaduras y hongos.

La proteína pertenece a la familia de las peptidasas $A 1$. En esta familia se han descrito proteínas tanto integradas en la membrana plasmática como secretadas.

Presenta una distribución amplia. Se han descrito proteínas homólogas en $F$. graminearum, Trichoderma harzianum (Hypocrea lixxi), Neurospora crassa, Podospora anserina, Magnaphorte grisea. y Chaetonium globosum, y está muy conservada (con homologías superiores al $75 \%$ ) en un rango de eucariotas.

La proteína presenta una homología del $73 \%$ con la aspartil proteasa SA76 (530 aa) de T. Harzianum. La enzima producida por 
el gen SA76 sobreexpresado en S. cerevisiae causa reducción en el crecimiento de varios hongos filamentosos, sustentando un papel como CWDE (Liu \& Yang, 2007).

\subsubsection{2 - Proteina semejante a glutamino amidotransferasa tipo 1 ("GAT1")}

Aparecieron fragmentos de este presunto gen en cinco clones. Su expresión es claramente inferior en el transformante silenciado 3.01 a las 48 horas, donde muestra una expresión del $21 \%$ respecto a la expresión del gen en el aislado silvestre. Sin embargo, en el transformantes 3.15 a las 24 horas, la expresión es solo ligeramente menor, con un valor del $68 \%$ respecto al tipo silvestre (100\%).

Existe en copia única en los genomas de F. oxysporum (06249), F. verticilloides (04101) y F. graminearum (09552). En F. oxysporum f.sp. lycopersici está presente en el cromosoma $2 \mathrm{~A}$ y muestra una fase de lectura de 1467 nt (1269 nt sin intrones) que se traducen en una proteína de 294 aa.

La comparación de la secuencia proteica en la base de datos PFAM y PROSITE no reveló la existencia de ningún dominio funcional, en cambio, el análisis en la base de datos NBCI-CDD reveló la existencia de un dominio similar a glutamino aminotransferasa tipo 1 (GATase 1-like) con una significación de 8e-15.

La proteína está presente en otros hongos filamentosos, pero no en el resto de hongos o eucariotas. Aparece con una homología significativa y función hipotética en $M$. grisea, N. crasa, C. globosum, $P$. anserina, Sclerotinia sclerotinia, Botrytis cinerea (Botryotinia fuckeliana), Pyrenophora tritici y Phaesphaeria nodorum (Septoria nodorum), en este último caso, la base de datos era de ESTs expresados durante la interacción entre el patógeno $P$. nodorum y el hospedador trigo.

\subsubsection{3 - Proteína de morfología y crecimiento de la célula ("Pal1")}

Este presunto gen aparece en un solo clon de la genoteca, pero el análisis de su expresión por Real-time PCR, revela diferencias de expresión mayores que algunos genes más representados en la genoteca substractiva. En 3.15 a las 24 horas, muestra una expresión del $21 \%$ respecto al tipo silvestre, y en 3.01 a las 48 horas, muestra un expresión del 44\% respecto al tipo silvestre. Es un caso claro de variación de la expresión.

El gen aparece en los genomas de $F$. oxysporum (05714), F. verticilloides (03580) y F. graminearum (04908). En F. oxysporum f.sp. lycopersici está en el cromosoma $2 \mathrm{~A}$ y muestra una secuencia de 1626 nt (1575 nt sin intrones), que se traduce en una secuencia proteica de 238 aa.

El alineamiento de esta secuencia tanto en PFAM como en NCBI-CDD, muestra un dominio Pal1 característico de la superfamilia de proteínas Pal1, implicadas en el mantenimiento de la morfología cilíndrica celular y asociadas a la membrana celular. La proteína Pal1p de Schizosaccharomyces 
pombe ha sido estudiada, y está regulada por la interacción de las proteínas Sla2 y End4p. Se ha comprobado que esta proteína Pal1p esta localizada en sitios de crecimiento activo (Ge et al., 2005).

La proteína es característica tanto de hongos filamentosos como de levaduras. Presenta una alta homología en los genomas de $M$. grisea, $P$. nodorum, S. sclerotiorum, $P$. tritici, B. fuckeliana, N. crassa y C. globosum.

\subsubsection{4 - Proteina de regulación del estrés} nutricional ("SIP5")

Se han encontrado fragmentos de este presunto gen en tres clones de la genoteca, lo que evidencia un fuerte componente diferencial, que se refrenda en las expresiones relativas. En ambos casos, tanto con 3.15 a las 24 horas como con 3.01 a las 48 horas, la expresión de los transformantes silenciados fue aproximadamente un $25 \%$ respecto la del aislado silvestre.

El gen esta presente en las bases de datos de los transcritos de $F$. oxysporum (02815), F. verticilloides (01645) y $F$. graminearum (08128). En F. oxysporum f.sp. lycopersici esta presente en el cromosoma 8, constituyendo un marco de lectura de 2545 nt (2496 nt sin intrones) que se traducen en una proteína de 831 aa.

El alineamiento de esta secuencia proteica en la base de datos PFAM indicó un dominio Clp amino terminal. Es un dominio común en bacterias y eucariotas sin una función clara, aunque relacionada con la interacción entre proteínas. En PROSITE se evidenció la existencia de un dominio de unión a $A D N$ tipo dedo de zinc $\mathrm{C}_{2} \mathrm{H}_{2}$, pero con una menor significación estadística.

El alineamiento en UNIPROT da una homología casi completa con la proteína SIP5 de C. globosum, N. crassa, M. grisea, Aspergillus spp., Penicillium spp., $P$. Nodorum, B. fuckeliana, S. sclerotiorum, $P$. tritici, entre otras.

La proteína SIP5 ("SNF1-interacting protein 5") ha sido estudiada experimentalmente en S. cerevisiae (489 aa), y regula negativamente la kinasa $S N F 1$, que está implicada en crecimiento con fuentes de carbono diferentes a glucosa y otros estreses nutricionales, promoviendo la unión del complejo fosfatasa REG1/GLC7 a la kinasa SNF1 (Sanz et al., 2000). Las secuencias proteicas de $S$. cerevisiae y $F$. oxysporum tienen una similitud del $44 \%$.

\subsubsection{5 - Proteína de transporte entre vesículas intracelulares ("sec17")}

Este presunto gen está presente en un solo clon de la genoteca. La búsqueda de homólogos en la base de datos del proyecto de genómica comparativa de Fusarium spp. muestra la existencia de una copia en los genomas de $F$. oxysporum (08026), $F$. verticilloides (04946) y $F$. graminearum (06277). En la propia base de datos del genoma de $F$. oxysporum f.sp. lycopersici la proteína aparece en el cromosoma 4 y está anotada como una proteína hipotética similar a la proteína de fusión vesicular sec17, y 
evidencia la existencia de una región AdAR (Aromatic-di-alanine repeat).

Aunque los valores de expresión en los transformantes silenciados si parecen bajos en ambos casos (entorno al 25\%), las desviaciones obtenidas para la expresión de este gen en el tipo silvestre no permiten conclusiones claras.

El marco de lectura tiene una longitud de $1408 \mathrm{nt}$ (1222 nt sin intrones) que se traducen en una proteína de 293 aa. El estudio de esta proteína en PFAM, verifica la existencia de dos regiones AdAR de once aminoácidos a partir de los residuos 36 y 137 , y que son característicos de proteínas conservadas implicadas en el transporte vesicular entre el retículo endoplasmático y el aparato de Golgi.

El alineamiento de la proteína en las bases de datos UNIPROT y NCBI, revela una homología claramente significativa con un buen número de hongos. Es homóloga a la proteína sec17 de $M$. grisea, $N$. fischeri y $A$. fumigatus, que también existe como proteina hipotética en $B$. fuckeliana, S. sclerotinium, $A$. capsulata, P. anserina, P. tritici, C. globosum, entre otros.

\subsubsection{6 - Proteina de catabolismo de la taurina ("TauD")}

Este presunto gen se encontró en uno de los clones. Existe en el genoma de $F$. oxysporum (00525) y F. verticilloides (00988), pero no en $F$. graminearum.

Los resultados de los estudios de expresión relativa no permiten concluir una reducción inequívoca de la expresión. En ambos casos el grado de expresión respecto del tipo silvestre y la desviación de los valores obtenidos son superiores a los esperados.

En F. oxysporum f.sp. lycopersici se encuentra en el cromosoma 1 y aparece catalogada como una proteína de la familia TfdA con un dominio enzimático de taurina (TauD -"taurine catabolism dioxygenase"), implicado en el catabolismo de sulfito a taurina, que es una fuente de azufre en condiciones de ausencia de azufre inorgánico.

El análisis en PFAM ratifica esta clasificación, sin embargo, el alineamiento en la base de datos de dominios conservados del NCBI (NCBI-CDD) predice en la misma región (aproximadamente entre los residuos 100 y 320) dos dominios: el dominio TauD (1e-17) y otro dominio similar a CAS (clavaminic acid synthetase) (1e-4), este último característico de la superfamilia de proteínas CAS implicadas en la biosíntesis de ácido clavulánico, relacionado con resistencia multidroga.

El alineamiento de la secuencia proteica en UNIPROT y NCBI, muestra una homología con proteínas hipotéticas en los genomas, entre otros, de $P$. anserina, $N$. crassa, C. globosum, M. grisea, A. nidulans, etc.; en el caso de $N$. fischeri (A. fischerianus), A. niger y $A$. fumigatus ha sido anotada como una proteína de la familia de oxidoreductasas TfdA con un dominio TauD. 
4.5.2.7 - Proteína de regulación de la transcripción génica ("TFIID")

Este presunto gen apareció en dos de los clones de la genoteca. Existe una copia prácticamente idéntica en los tres genomas: F. oxysporum (03223), F. verticilloides (02094) y F. graminearum (08427). En F. oxysporum f.sp. lycopersici se integra en el cromosoma 8 , constituyendo un marco de lectura de 3087 nt (2704 nt sin intrones) que se traducen en una proteína de 254 aa.

En el estudio de la expresión relativa en el transformante 3.01 a las 48 horas, la reducción de la expresión del gen es clara, siendo el $15 \%$ de la expresión del gen en el aislado silvestre. Por el contrario, en el aislado 3.15 a las 24 horas, apenas hay diferencias respecto al tipo silvestre, y los valores y desviaciones obtenidas no permiten concluir que exista una reducción de la expresión del gen.

El proyecto de secuenciación la anota como una proteína TBP (TATA-box binding protein) que junto a otros factores de transcripción (TAFs) forman los complejos de iniciación de transcripción (ésta en concreto el TFIID), que durante la transcripción se unen al promotor del gen regulado para permitir la acción de las ARN polimerasas (ésta en concreto la ARN polimerasa II).

Los 180 residuos C-terminales están muy conservados en eucariotas y se unen estructuralmente al ADN, el resto de la secuencia es específica de cada proteína.
La proteína tiene una homología prácticamente completa con otras proteínas TBP de hongos.

\subsubsection{8 - Proteína piruvato descarboxilasa ("Tiamina")}

Se encontraron fragmentos de este gen en cinco clones de la genoteca. Estos fragmentos muestran homología con una región del genoma de F. oxysporum (08146) y $F$. verticilloides (05069) y $F$. graminearum (09834). En F. oxysporum f.sp. lycopersici, el gen esta situado en el cromosoma 4, tiene una longitud de $2299 \mathrm{nt}$ (2182 nt sin intrones) que se traduce en una proteína de 570 aa.

En los dos estudios de expresión relativa se observó una reducción clara de la expresión del gen, con valores de expresión respecto al tipo silvestre del $45 \%$ en 3.15 a las 24 horas y $15 \%$ en 3.01 a las 48 horas.

En la base de datos del proyecto de secuenciación la proteína aparece anotada como una proteína hipotética similar a una Piruvato descarboxilasa $(P d c A)$, presentando los tres dominios característicos de esta proteína: dos dominios de unión a tiamina pirofosfato, uno C-terminal y otro N-terminal, y entre ellos un dominio enzimático.

Estos mismos resultados se obtienen en PFAM. Muchas enzimas presentan dominios de unión a tiamina pirofosfato (vitamina B1) que actúa como cofactor.

Cuando la secuencia proteica se usa para un alineamiento en las bases de datos UNIPROT y NCBI, se obtiene homología completa con un buen número de proteínas 
fúngicas, muchas hipotéticas y una parte descritas como Piruvato descarboloxilasas $(P d c A)$. La proteína esta muy conservada, con apenas cambios, en ascomicetos y basidiomicetos.

\subsubsection{9 - Proteína de respuesta a hipoxia mitocondrial ("hipox")}

El fragmento de este presunto gen se encontró en cuatro clones de la genoteca. La secuencia da homología con un gen de $F$. oxysporum (16588), F. verticilloides (13646) y F. graminearum (03448).

La reducción de la expresión es clara en 3.15 a las 24 horas, con una expresión del $28 \%$ respecto al tipo silvestre. No así en 3.01 a las 48 horas, donde la reducción es menor y la expresión respecto al tipo silvestre es de aproximadamente un $60 \%$, si bien la desviación del dato es significativa.

En F. oxysporum f.sp. lycopersici el presunto gen está situado en el cromosoma 11 , y constituye un marco de lectura de 916 nt (869 nt) que se traduce en una proteína de 228 aa.

La proteína presenta, tanto en PFAM como en NCBI-CDD, una región conservada en proteínas inducidas en situación de hipoxia mitocondrial, la superfamila de proteínas HIG-1.

La comparación de la secuencia proteica revela que es una proteína muy conservada que aparece en un limitado número de hongos filamentosos: $F$. graminearum, M. grisea, C. globosum, $P$. anserina, B. fuckeliana, S. sclerotiorum, $P$. nodorum y $N$. crassa, y con una menor homología en levaduras, existiendo una separación clara entre los dos tipos de hongos.

\subsubsection{0 - Proteína desconocida 03747 (03747)}

El fragmento correspondiente a este gen apareció en dos de los clones de la genoteca. La comparación con la base de datos verificó su existencia en los genomas secuenciados de $F$. oxysporum (03747), $F$. verticillioides (12116) y $F$. graminearum (07925), en los tres casos habiendo sido anotada como proteína hipotética conservada.

Tanto en el transformante 3.15 a las 24 horas, como en el transformante 3.01 a las 48 horas, se observa una clara reducción de la expresión del gen con valores de expresión del $34 \%$ (3.15) y $22 \%$ (3.01), respecto al tipo silvestre.

En F. oxysporum f.sp. lycopersici, el gen aparece en el cromosoma 4, tiene una longitud de $1385 \mathrm{nt}$ (1231 nt sin intrones) que se traducen en 268 aa. En el genoma de $F$. oxysporum f.sp. lycopersici, el ORF contiguo aguas abajo (03748) presenta un dominio del tipo dedo de zinc $\mathrm{Zn}(\mathrm{II})_{2} \mathrm{Cys}_{6}$. El ORF contiguo aguas arriba (03746) es una proteína similar a una Trehalosa fosfatosintasa (implicada en metabolismo de carbono).

No se predicen dominios ni regiones conocidas en ninguna de las bases de datos consultadas: PFAM, NCBI, PROSITE.

La proteína presenta una gran homología en otros ascomicetos, y bastante 
menor pero significativa en basidiomicetos, y no aparece en otros organismos.

\subsubsection{1 - Proteína desconocida 04611 (04611)}

Se trata de la secuencia más repetida, ya que apareció en siete clones de la genoteca. El gen está presente en $F$. oxysporum (04611) y $F$. verticilloides (07741), pero no en $F$. graminearum cuando se hace una búsqueda Blast en la web del Broad Institute. En cambio, si dio homología en $F$. graminearum en una búsqueda Blast en NCBI usando la secuencia aminoacídica hipotética.

Presenta una reducción en ambos estudios de expresión relativa, pero es relevante en el caso de 3.01 a las 48 horas donde se observa una reducción a solo el 16\% (considerando el 100\% la expresión del aislado silvestre). En 3.15 la expresión es entorno al $60 \%$ respecto al tipo silvestre.

En F. oxysporum f.sp. lycopersici está presente en el cromosoma 4, y el marco de lectura tiene un longitud de 3689 nt (3639 nt sin intrones) que se traduce en una proteína de 1212 aa. El análisis de la secuencia en PFAM, NCBI-CDD y PROSITE no reveló la existencia de dominios conservados.

En F. oxysporum f.sp. lycopersici, la proteína inmediatamente aguas arriba (04612 -292 aa-) es homóloga (6e-6) a una proteínasa de pared que en los ascomicetos patógenos de humanos Coccidioides posadassi y C. immitis ha sido descrita como expresada durante la segmentación de la pared y la diferenciación en endosporas. La proteína está también presente en $P$. anserina (9e-18) y C. globosum (6e-17), pero no otros hongos. El resto de proteínas aguas arriba y aguas abajo, no tienen función conocida y se caracterizan por el pequeño rango de organismos con el que presentan homología.

Presenta una distribución reducida. Además de las especies del género, aparece solo con una homología significativa en otros ascomicetos como C. globosum, P. anserina, N. crassa y C. immitis.

\subsubsection{2 - Proteína desconocida 08338 (08338)}

Un fragmento de este gen apareció en tres clones diferentes. El análisis de la secuencia en la base de datos de los transcritos de Fusarium sp. revela una homología en $F$. oxysporum (08338) y $F$. verticilloides (06335), pero no en $F$. graminearum.

Tanto en 3.15 a las 24 horas como en 3.01 a las 48 horas presenta una reducción de expresión. La expresión respecto al tipo silvestre es aproximadamente un $25 \%$ en 3.15 y un $45 \%$ en 3.01 .

En F. oxysporum f.sp. lycopersici, el gen se sitúa en el cromosoma 2, y el marco de lectura tiene una longitud de 817 nt (754 nt sin intrones) que se traducen en una proteína de 113 aa. Ninguna base de datos revela la existencia de dominios conservados.

La comparación en la base de datos del NCBI no revela homologías significativas, pero en UNIPROT presenta homología con una proteína de unión a ARN de cordados. 


\section{5 \\ Discusión}



5.1 - Nuevos aislados supervirulentos de $F$.

oxysporum f.sp. phaseolicon una copia

adicional de ftf1

La virulencia de veinticinco estirpes de $F$. oxysporum aisladas de $P$. coccineous fue caracterizada mediante ensayos en invernadero en plantas de judión y judía. Solo hemos podido encontrar un estudio previo que describiese la interacción $F$. oxysporum P. coccineous (Aloj et al., 1983). En ensayos en judión, nueve de los aislados mostraban una virulencia mayor con valores en la escala CIAT cercanos a 9 tras dos semanas. Se les denominó supervirulentos y constituyen un nuevo grupo de virulencia. El resto de aislados también pudo dividirse en otros dos grupos de virulencia: Nueve aislados mostraban una virulencia menor que el grupo de supervirulentos, con valores en la escala CIAT superiores a 7 tras cuatro semanas, lo que coincide con el grupo de altamente virulentos en judía, por lo que denominamos a este grupo como altamente virulentos. El tercer grupo está formado por siete aislados cuyos valores en la escala CIAT son inferiores a 7 tras cuatro semanas de infección, como el grupo caracterizado en judía como débilmente virulentos, por lo que los denominamos débilmente virulentos. En judía, los aislados que pertenecen a distintos grupos de virulencia en judión, se comportaron como altamente virulentos en judía.

La significación estadística de los grupos fue verificada mediante un Análisis de la varianza (One-way ANOVA). También usamos el índice D.P.R. (García-Sánchez, 2007), que demostró ser un valor estadístico muy adecuado para discriminar los aislados según su grupo de virulencia Los resultados obtenidos al utilizar los valores D.P.R. en estas estirpes coinciden con aquellos resultantes de la aplicación del Análisis de la varianza (ANOVA).

Hemos descrito cuatro nuevos grupos de compatibilidad vegetativa (VCG) pues nuestros aislados no formaban heterocariontes con ningún representante de los VCG previamente descritos. Los hemos nombrado 0169, 01610, 01611 y 01612.

Mediante hibridaciones Southern con sondas del promotor y región codificante de ftf1 caracterizamos el número de copias de ftf1 en las nuevas estirpes. En estudios previos con las mismas sondas, las estirpes altamente virulentas mostraron 5 bandas, que se corresponden con 4 copias polimórficas de ftf1 y una de ftf2, mientras que las estirpes débilmente virulentas mostraban una única banda que se corresponde con ftf2 (Ramos, 2005; Ramos et al., 2007). Todos los aislados supervirulentos mostraron una banda más que el resto de los aislados, lo que sugiere una copia adicional de ftf1. Sin embargo, algunos aislados clasificados en ensayos de virulencia en judión como altamente virulentos, e incluso un aislado clasificado como débilmente virulento, mostraban también esta banda adicional.

Por otro lado, los aislados FOP-SP36 y FOP-SP37 se comportaron como altamente virulentos en los ensayos en judía, si bien las hibridaciones Southern mostraron una única 
banda, como la presente en los aislados débilmente virulento (FOP-SP4) y no patógeno (AB7), que se correspondería con ftf2. En estudios previos, los aislados patógenos españoles se subdividían en dos grupos (altamente virulentos y débilmente virulentos) según el grado de virulencia estimado conforme al índice de producción de enfermedad de la escala CIAT (PastorCorrales \& Abawi, 1987) solo en variedades de judía españolas, pero no en variedades de judía con otros orígenes geográficos (AlvesSantos et al., 2002a). De forma similar, los aislados de F. oxysporum f.sp. phaseoli recogidos en judión solo muestran diferentes grados de virulencia en ese hospedador.

Aparentemente la virulencia es una interacción altamente específica con el hospedador (Sacristán \& García-Arenal, 2008) y aparentemente la virulencia es característica para una interacción entre un patógeno y un hospedador. En el caso de $F$. oxysporum f.sp. phaseoli, esta especialización fisiológica no es sorprendente teniendo en cuenta la diversidad genética de los cultivares de judía (Velasquez \& Gepts, 1994; Kwak \& Gepts, 2009) y la existencia de procesos de coevolución demostrados en la interacción de judía en otros hongos patógenos como Phaeoisariopsis griseola (Guzmán et al., 1995) y Colletotrichum lindemuthianum (Geffroy et al., 1999).

La relación entre virulencia y el número de copias de un factor de virulencia se ha descrito en Pyrenophora triticisrepentis, donde la virulencia esta determinada por el número de copias de genes productores de toxinas específicas de hospedador (HST) como ToxB. En este caso, el aislado 92-171R5, que parece tener dos copias de ToxB, es menos virulento que el aislado ALG3-24, en el que se han estimado ocho copias (Strelkov et al., 1999; Martinez et al., 2001; Strelkov et al., 2002; Martinez et al., 2004). En F. oxysporum, el caso del gen Tom1 es parecido al de ftf1. Tom1 está presente en al menos cinco copias en $F$. oxysporum f.sp. lycopersici, y produce la enzima tomatinasa implicada en la resistencia a las defensas de la planta. La sobreexpresión del gen produce un incremento de la virulencia mientras que la interrupción de una de las copias causa un retardo en el progreso de la enfermedad (Pareja-Jaime et al., 2008).

En F. oxysporum f.sp. phaseoli la interrupción de una de las copias de ftf1 no determinó pérdida de la virulencia en el correspondiente mutante (Ramos et al., 2007). La relación entre virulencia y número de copias de ftf1 no es clara. Por un lado, esta sugiere una relación entre el número de copias de ftf1 y la virulencia. Por otro, la ausencia de fenotipo en los transformantes interrumpidos y la existencia de aislados con el mismo número de copias polimórficas pero distinta virulencia en ensayos de infección, parecen sugerir que no todas las copias son funcionales.

Los aislados supervirulentos con la copia adicional de ftf1 pertenecen al mismo VCG, tienen el mismo patrón RFLP del IGS del ADN ribosómico y el mismo idiomorfo MAT1-2, que aislados que no tienen esa 
copia adicional. Esto sugiere que la única diferencia entre ellos es la aparición de esta copia adicional de ftf1 en algún momento reciente. En estudios anteriores se comprobó que las estirpes débilmente virulentas pertenecen a un VCG (0166) distinto al de las estirpes altamente virulentas. También, que todas las estirpes pertenecientes a un mismo VCG pertenecían al mismo grupo de virulencia (Alves-Santos et al., 1999; AlvesSantos et al., 2002). Sin embargo, en las nuevas estirpes aisladas de $P$. coccineous se observa variabilidad fisiológica (diferencias en virulencia) entre estirpes con una variabilidad genética prácticamente nula.

\section{2 - La expresión de ftf2 es estable durante el}

crecimiento y la infección, e independiente de la virulencia del aislado

Se cuantificó la expresión del gen ftf2 en un representante de cada uno de los grupos de virulencia descritos, tanto durante el crecimiento en medio de cultivo líquido como durante la infección de plantas de judía.

El perfil de expresión del gen ftf2 es bastante constante (no presenta picos o valles) y parecido en diferentes medios y en aislados pertenecientes a distintos grupos de virulencia. En el caso de FOP-SP4, la expresión de ftf2 parte de niveles muy bajos a las 6 horas y va aumentando en el tiempo (más rápido en cultivo líquido que en planta tras la infección) hasta estabilizarse. En otras estirpes, como FOP-SP13 y AB82, la expresión de ftf2 se mantiene estable desde el inicio. La expresión de ftf2 en FOP-SP01 es más irregular pero se mantiene dentro del mismo rango de valores que el resto. La estabilidad de la expresión de ftf2 se aprecia mejor a tiempos largos (a partir de las 72 horas), cuando apenas hay diferencias entre las estirpes, tanto en cultivo líquido como en infección en planta.

La expresión de ftf2 es similar durante el crecimiento en cultivo líquido y en los ensayos de infección en planta de judía, esto es, en ausencia o presencia de la planta. Esto se aprecia bien comparando los perfiles de expresión de FOP-SP13 o FOP-SP4 en las dos condiciones. En consecuencia, ftf2 parece no tener un papel relevante durante la infección en la planta. También podríamos descartar que ftf2 tenga efecto sobre la virulencia, pues no hay diferencias significativas en su expresión entre un aislado débilmente virulento (SP4) y un aislado supervirulento (SP13) ni durante el crecimiento ni durante la infección.

La ausencia de variaciones relevantes en la expresión de ftf2 sugiere una relación con un proceso constante en el organismo. La mayoría de proteínas que tienen un dominio dedo de zinc binuclear $\mathrm{Zn}(\mathrm{II})_{2} \mathrm{Cys}_{6}$, como ftf2, están implicadas en procesos básicos como regulación de metabolismo primario 0 secundario (Todd \& Andrianopoulos, 1997; MacPherson et al., 2006), resistencia a drogas (Balzi et al., 1987; McGuire et al., 1995; Akiyama \& Nakashima, 1996), desarrollo meiótico (Strich et al., 1994), segregación de cromosomas (Lechner, 1994), etc . 


\section{3 - El gen ftf1 está sobreexpresado en etapas}

tempranas de la infección en estirpes

supervirulentas y altamente virulentas

La expresión de ftf1 se cuantificó mediante Real-time PCR en los nuevos aislados supervirulentos y se comparó con la expresión de los aislados altamente virulentos. En cultivo líquido, la expresión de ftf1 es prácticamente invariable en el tiempo y muy parecida en la estirpe supervirulenta (FOP-SP13) y altamente virulenta (FOP-SP1). En estudios previos, in vitro se detectaron niveles expresión de ftf1 cercanos a los umbrales de detección de la Real-time PCR y no detectables por las técnicas de PCR convencional o hibridación tipo Northern (Ramos, 2005).

En cambio, como ya se había comprobado en estudios anteriores (Ramos et al., 2007), en planta muestra un drástico incremento en las primeras 24 horas. Sin embargo, mientras en el aislado supervirulento el pico de expresión a las 24 horas alcanza 15 veces el nivel estable, en el aislado altamente virulento el pico es de 11 veces el nivel estable.

Aunque se detecta expresión de ftf1 en ausencia de la planta, no presenta el incremento de expresión que se observan en presencia de la misma. En cultivo líquido tampoco hemos detectado diferencias entre aislados con diferente número de copias de $f t f 1$. El gen ftf1 podría tener actividad residual fuera del proceso de infección, pero por la similitud de la región codificante de ftf1 y ftf2, y dado que este último también se expresa durante el cultivo en medio líquido, las funciones de los dos genes serían complementarias.

La expresión de ftf1 en planta es una prueba importante a favor de un papel relevante de ftf1 como factor de virulencia en las etapas tempranas del proceso de infección. La expresión de ftf1 en la estirpe supervirulenta es un $31,25 \%$ mayor que la estirpe altamente virulenta, lo que es proporcional al número de copias de ftf1 conocidas para cada uno de ellos (cinco y cuatro, respectivamente). Esto sugiere una relación entre el número de copias funcionales de ftf1 y el pico de expresión del gen, y en este caso, el número de copias funcionales en ambos (si no son todas) debería mantener esta proporcionalidad.

\section{4 - Arquitectura genómica de ftf1 y ftf2 en el} género Fusarium y otros hongos filamentosos

El gen ftf2 es un gen presente exclusivamente en hongos ascomicetos. Presenta homología significativa en las bases de datos de 17 organismos que se alinean formando dos grandes grupos filogenéticos, y en ambos se incluyen organismos patógenos y no patógenos. Anteriormente, ya se había comprobado experimentalmente la presencia de ftf2 en cinco organismos ( $F$. solani, $F$. moniliforme, $F$. graminearum, B. cinerea y $T$. harzianum) y también en las bases de datos de los genomas de $M$. grisea, N. crassa, A. nidulans, $A$. fumigatus, $S$. pombe, $S$. cerevisiea y $U$. maydis, encontrándose también en patógenos y no patógenos 
(Ramos, 2005). Desde el estudio anterior se han incorporado nueve genomas a la lista de aquellos disponibles. En el subgrupo de $F$. oxysporum, se incluyen otros piromicetos 0 sordariomicetos. Además de F. graminearum, cuya secuencia de ftf2 es prácticamente igual a la $F$. oxysporum, tenemos dos patógenos (M. grisea y C. globosum) y dos nos patógenos ( $N$. crassa y $P$. anserina). Las regiones flanqueantes del locus ftf2 están conservadas en las especies del genero ( $F$. graminearum y $F$. verticilloides), en menor medida en $M$. grisea y son claramente distintas en $N$. crassa, pese a que la homología entre los genes de $F$. oxysporum, $M$. grisea y $N$. crassa es alta. La observación de que ftf2 no tenga un papel en patogenicidad concuerda con la distribución que hemos obtenido: excluyendo Fusarium spp. las cuatro mayores homologías se reparten entre hongos patógenos (como $M$. grisea y C. globosum) y no patógenos (como $N$. crassa y $P$. anserina), todos pertenecientes a la familia de los piromicetos o sordariomicetos.

En los genomas de $F$. graminearum y F. verticilloides obtenemos una única secuencia homóloga, que corresponde al gen ftf2. En el genoma secuenciado de $F$. oxysporum, correspondiente a la estirpe 4287 de la forma especial lycopersici (FGSC 9935), existen 11 copias homólogas a los genes ftf1 y ftf2 identificados en $F$. oxysporum f.sp. phaseoli.

En el análisis genómico de $F$. graminearum, se encontraron pocos genes duplicados y los que existían presentan un gran número de mutaciones (Cuomo et al., 2007). Ese no parece ser el caso de $F$. oxysporum, cuyo tamaño de genoma es el doble de grande que el de $F$. graminearum, y en el que se han descrito casos de duplicación de genes implicados en patogenicidad, como los genes Six (Houterman et al., 2007; van der Does \& Rep, 2007), además de ftf1 (Ramos et al., 2007). Esta diferencia en el tamaño de los genomas podría explicarse por las diferencias en su reproducción. En $F$. oxysporum al no existir (probablemente) reproducción sexual la diversidad genética se basa en otros procesos que favorecen la existencia de regiones duplicadas, como la heterocariosis (Teunissen et al., 2002) y la acción de transposones (Daboussi \& Capy, 2003).

La presencia de ftf1 en otras formas especiales ya había sido demostrado mediante PCR (Nuñez Corcuera, 2004). Mediante hibridaciones tipo Southern cuantificamos el número de copias polimórficas de $f t f 1$ en varias formas especiales de $F$. oxysporum. El número de copias de ftf1 resultó ser altamente variable entre las diferentes formas especiales y aún entre aislados de la misma forma especial. La variación en el número de copias de ftf1 entre aislados de una misma forma especial se había comprobado en $F$. oxysporum f.sp. phaseoli (Alves-Santos et al., 1999).

También amplificamos el comienzo de la región codificante de una de las copias de ftf1 en varias formas especiales de $F$. oxysporum. Aislados de distintas formas especiales mostraban secuencias iguales 
entre si, como las formas especiales phaseoli y lycopersici; y entre betae, nicotiana y pini. Una alta homología (88-92\%) en ftf1 entre 5 formas especiales de F. oxysporum (pisi, lycopersici, betae, vasinfectum y lupini) ya había sido comprobada (Nuñez Corcuera, 2004). Cuando hemos comparado las secuencias completas disponibles de ftf1 y ftf2 en $F$. oxysporum en las formas especiales lycopersici y phaseoli, hemos visto que la copia de ftf1 secuenciada en la forma especial phaseoli (ftf1a) es más parecida a una de las copias de la forma especial lycopersici (01) que esta última al resto de copias del mismo aislado. También comprobamos que la copia identificada como ftf2 en F. oxysporum f.sp. phaseoli es igual a la copia 04 de F. oxysporum f.sp. lycopersici.

Una explicación para la existencia de copias iguales en aislados de distintas formas especiales, es que haya casos donde la especialización de hospedador haya sido posterior a las duplicaciones de ftf1. Se ha comprobado que las formas especiales en $F$. oxysporum no tienen un origen monofilético (Alves-Santos et al., 1999) y que aislados con el mismo ancestro (deducido del análisis de polimorfismos en el transposón Impala) tienen diferente hospedador (Hua-Van et al., 2001). Por ejemplo, en $A$. alternata el hospedador está determinado por la producción de toxinas HST que se ganan y pierden por transposición y transferencia horizontal de genes (HGT) variando la especificidad (Hatta et al., 2006; van der Does \& Rep, 2007). Un estudio de los polimorfismos de las secuencias completas de las copias del gen ftf1 en las distintas formas especiales permitiría un análisis más preciso de la relación evolutiva entre distintas formas especiales.

Tanto en F. oxysporum f.sp. lycopersici, como en la forma especial phaseoli, algunos de los aislados presentan una copia adicional. En el caso de la forma especial lycopersici, encontramos aislados con 4 o 5 copias de ftf 1 , si bien el número de bandas (copias con distinto patrón de restricción) en la hibridación Southern con la sonda de la región codificante M18B-M19A, es significativamente menor que el número de copias encontradas en el genoma secuenciado (estirpe 4287), tras el análisis de la disposición de los sitios Hindlll hemos sido capaces de asignar cada banda a sus respectivas copias. Las copias 02 y 03; y 07, 08, 09 y 10; al ser iguales entre si muestran los mismos polimorfismos. Estos dos grupos, que se corresponden con las bandas de 8,96 $\mathrm{Kb}$ y 7,2 Kb se suman a 01 (3,9 Kb), 04 (3,5 Kb.), 05 (3,4 Kb), 06 (10,5 Kb) y $11(11 \mathrm{~Kb})$ formando las 7 bandas observables en la hibridación. Se verifica además, que la copia 04 homóloga a ftf2, se corresponde con la banda de 3,5 Kb que esta presente en todos los aislados.

Se ha constatado la proximidad del transposón Marsu a las copias de ftf1 en $F$. oxysporum f.sp. phaseoli (Ramos et al., 2007), y hemos comprobado que cinco de las copias de ftf1 en $F$. oxysporum f.sp. lycopersici muestran fragmentos del transposón Impala en la región promotora. Esto nos hace pensar que los responsables 
de las duplicaciones de ftf1 son elementos transponibles. En F. oxysporum f.sp. lycopersici, el gen Six1-H, copia truncada del gen de avirulencia Six1, está interrumpido por el transposon Drifter en su región codificante (Rep et al., 2005), y la inserción de un transposón en el promotor del gen Avr-Pita de $M$. oryzae conlleva la perdida de función del mismo (Kang et al., 2001). El gen multicopia ToxB que codifica una HST en $P$. tritici-repentis muestra la existencia de porciones de transposones en las regiones próximas (Martinez et al., 2004). En F. solani (Nectria haematococca) algunos genes de virulencia se disponen en un pequeño cromosoma supernumerario con una gran densidad de transposones (Liu et al., 2003; Temporini \& VanEtten, 2004) y en Cochliobolus carbonum siete genes codificantes de toxinas HST aparecen múltiples veces en el mismo cromosoma (Ahn et al., 2002).

En F. oxysporum f.sp. lycopersici, la región codificante está conservada en las distintas copias con una homología de aproximadamente el $90 \%$ pero la región promotora presenta diferencias importantes debido a la presencia del transposón Impala en el promotor, entorno a 300-400 bp aguas arriba de los presuntos codones de inicio de la traducción en varias de las copias $(05,06$, $07,08,09$ y 10). Cuando hemos analizado las secuencias proteicas en estas copias, se ha comprobado la existencia de cierta variación en la parte final de la proteína, que se traduce en una proteína de menor longitud. Además, solo dos codones ATG están conservados en todas las copias, y muchas presentan otros codones ATG propios, lo que hace que la longitud final de la proteína sea difícilmente estimable. Estos hechos plantean interrogantes sobre la funcionalidad de estas copias. En los factores de transcripción $\mathrm{Zn}(\mathrm{II})_{2} \mathrm{Cys}_{6}$, el extremo C-terminal se corresponde con el dominio de activación y su modificación causa la perdida o modificación de la función del mismo (MacPherson et al., 2006).

Las dos copias secuenciadas de $F$. oxysporum f.sp. phaseoli solo variaban en un nucleótido (Ramos, 2005) pero las distintas copias de ftf1 en $F$. oxysporum f.sp. lycopersici presentan una mayor variación, hasta el punto de dificultar gravemente la predicción sobre el número de copias funcionales. Las regiones genómicas y los genes concretos implicados en virulencia suelen tener altas tasas de polimorfismo probablemente como consecuencia de la presión selectiva para escapar de la detección por el hospedador (van der Does \& Rep, 2007). En F. graminearum el análisis genómico detectó mayores tasas de polimorfismo en las regiones que contienen los genes implicados en la interacción plantapatógeno (Cuomo et al., 2007).

En varias especies de hongos se ha comprobado que los genes de virulencia se disponen en el mismo cromosoma. Tal es el caso de Colletotrichum gloesporioides ( $\mathrm{He}$ et al., 1998), Nectria haematococca (Han et al., 2001), Neocosmospora boniensis (Temporini \& VanEtten, 2004), Alternaria alternata (Hatta et al., 2002) y F. solani (Liu et al., 2003; 
Temporini \& VanEtten, 2004). Se ha propuesto que estos agrupamientos son consecuencia de la transferencia horizontal de genes (HGT) y/o el agrupamiento por la acción de transposones por presión selectiva (por ejemplo porque facilite la regulación o los procesos de mutación y transferencia) (van der Does \& Rep, 2007). En F. oxysporum f.sp. lycopersici los genes Six1, Six2, una copia truncada del primero denominada Six $1-H, y$ un conjunto de genes que codifican proteínas secretadas tras la infección se encuentran en el mismo cromosoma (van der Does et al., 2008). Lo mismo sucede con ftf1 en $F$. oxysporum f.sp. phaseoli, donde todas las copias de este gen se disponen en el cromosoma de menor tamaño (Ramos et al., 2007), pero no en $F$. oxysporum f.sp. lycopersici, donde las copias se distribuyen en seis cromosomas distintos.

En aislados patógenos del ascomiceto Pyrenophora tritici-repentis el gen multicopia ToxB es una tóxina determinante de la especificidad de hospedador (HST) que presenta una identidad del $86 \%$ con el gen toxb presente en una única copia en aislados no patógenos de $P$. tritici-repentis y otros hongos filamentosos. La función de toxB es desconocida y no se observa expresión en las mismas condiciones que ToxB (Martinez et al., 2004). En el mismo organismo se ha comprobado que la inserción del gen ToxA en un aislado no patógeno es suficiente para convertirlo en un aislado patógeno (Ciuffetti et al., 1997). Las semejanza entre los dos casos sugieren que ftf1, distribuido irregularmente en múltiples copias, habría surgido en aislados concretos de $F$. oxysporum a partir de ftf2, presente en una única copia en varios organismos. El origen de los genes de virulencia a partir de genes no implicados en patogenicidad y con una función básica ha sido previamente discutido (van der Does \& Rep, 2007). Varios genes identificados como factores de patogenicidad cuya disrupción conlleva la perdida de la capacidad infecciosa participan también en procesos generales como conidiación (Jain et al., 2002; Jain et al., 2003), crecimiento (Caracuel et al., 2005; Duyvesteijn et al., 2005; Divon et al., 2006; Martinez-Rocha et al., 2008), respuesta a estrés (Canero \& Roncero, 2008) o apareamiento (Duyvesteijn et al., 2005; Prados Rosales \& Di Pietro, 2008), lo que sugiere que la patogenicidad se adquiere por optimización de rutas metabólicas y de regulación comunes (Duyvesteijn et al., 2005).

\section{5 - Los transformantes silenciados muestran una reducción del crecimiento, la esporulación y, en algunos casos, de la virulencia}

Para generar transformantes con la expresión de ftf1 y ftf2 eliminada o atenuada, diseñamos una construcción de silenciamiento que se basa en un plásmido binario en el que se han introducido dos copias homólogas amplificadas de una región conservada en ftf1 y ftf2, dispuestas en sentidos contrarios. Como novedad en el diseño del plásmido, nuestra construcción usa como espaciador entre los dos fragmentos en sentidos contrarios una región 
del propio gen diana en lugar de un intrón (que es la solución más común usada con anterioridad) (Hamada \& Spanu, 1998; Fitzgerald et al., 2004; Janus et al., 2007). Esta alternativa se ha demostrado como simple y eficiente pues la construcción se limita a una ligación conjunta de tres fragmentos.

Hemos silenciado mediante interferencia de RNA (RNAi) estirpes patógenas (FOP-SP13, FOP-SP1 y FOP-SP4) y no patógenas (AB82) de F. oxysporum f.sp. phaseoli recogidos en campo, con diferencias genéticas apreciables entre ellos. También hemos obtenido transformantes a partir de una estirpe de F. oxysporum f.sp. lycopersici (Strain I. Phytopathology Lab. Wageningen University). Previamente, el silenciamiento mediado por RNAi ya había sido probado en F. graminearum (McDonald et al., 2005), pero no en $F$. oxysporum. También se había probado en otros hongos como ascomicetos (Hamada \& Spanu, 1998; Fitzgerald et al., 2004; Janus et al., 2007), basidiomicetos (Namekawa et al., 2005; Laurie et al., 2008) y zigomicetos (Nicolas et al., 2003).

La secuencia molde de la construcción de silenciamiento está completamente conservada tanto en ftf1 como en ftf2. Como consecuencia de ello, parece razonable suponer que se produce un silenciamiento conjunto de ambos genes. En M. grisea (M. oryzae) se ha verificado el silenciamiento simultáneo de genes con una homología menor (E-value 10e-3) que la de ftf1 y ft2 en esta región; en algunos casos también detectaron el silenciamiento de genes menos parecidos (Nguyen et al., 2008). Por esta característica, el silenciamiento ha sido usado en el silenciamiento de varios genes parecidos (Fitzgerald et al., 2004; Matityahu et al., 2008; Lacroix \& Spanu, 2009) o familias génicas (Nguyen et al., 2008).

Los transformantes silenciados en $\mathrm{ftf} 2$ muestran reducción en la tasa de crecimiento en varios medios y, en algunos casos, una reducción de la tasa de producción de esporas, pero no ven afectada su virulencia. Los transformantes silenciados en ftf1 y ftf2 muestran también reducción en la tasa de crecimiento y de la esporulación, y además, a diferencia del caso anterior, sí muestran una disminución de la virulencia. Los transformantes silenciados en ftf1 y ftf2, obtenidos por transformación de FOP-SP13 (nombrados 1.XX) o FOP-SP01 (nombrados 2.XX), no muestran mayores reducciones en el crecimiento que los transformantes silenciados sólo en ftf2, como los obtenidos por transformación de FOP-SP4 (nombrados 3.XX) o AB82 (nombrados 4.XX). Además, las estirpes silvestres con ftf1 (FOP-SP13 y FOPSP01) no presentan tasas de crecimiento o esporulación superiores a las estirpes que sólo tienen ftf2 (FOP-SP04 y AB82). Por ejemplo, tras 5 días de cultivo en medio rico sólido (PDA) de FOP-SP013 y FOP-SP04 es igual (32 mm), o mientras que la esporulación de FOP-SP013 es mucho mayor que la de FOP-SP04, la de FOP-SP01 es muy inferior a esta última. Por ello, no parece que ftf1 esté implicado en estos procesos biológicos, lo cual indica que las alteraciones en el crecimiento y la esporulación de los 
silenciados en ftf2 o en ftf1 y ftf2, parecen debidas al silenciamiento de ftf2 en ambos casos.

Para descartar que estos fenotipos se debieran al proceso de transformación en si mismo, transformamos al mismo tiempo con otra construcción análoga (pS3) que portaba el cassette de resistencia a la higromicina pero no las regiones de los genes ftf1 y ftf2 para el silenciamiento. En este caso no se observaron alteraciones en el crecimiento.

Cuando se analizan las tasas de crecimiento de los transformantes silenciados obtenidos a partir de una misma estirpe silvestre, se observa un gradiente, en el cual, sin embargo, se pueden hacer dos grupos con significación estadística. El grupo mayoritario está formado por los transformantes silenciados que no muestran diferencias estadísticamente significativas respecto del tipo silvestre. El segundo grupo, minoritario, lo forman transformantes en los que la reducción es claramente significativa. En nuestro caso, el grado de alteración de la velocidad de crecimiento se ha mostrado como un criterio de discriminación muy bueno para diferenciar transformantes con fenotipos muy distintos al tipo silvestre. Estos transformantes son los que denominamos fuertemente silenciados. Tras la transformación de las estirpes silvestres, los transformantes fuertemente silenciados fueron el 10,3\% (3 de 29), 20,6\% (7 de 34), $21,4 \%$ (3 de 14) y $30,8 \%$ (4 de 13) de los obtenidos de AB82, FOP-SP04, FOP-SP01 y FOP-SP013, respectivamente.
Nuestros resultados no son distintos de los observados en el silenciamiento génico de otros hongos. Al igual que en nuestro caso, pero usando el gen que codifica la proteína fluorescente DsRed se evaluó el silenciamiento en dos estirpes del hongo Acremonium chrysogenum con dos plásmidos distintos, y se obtuvo un gradiente de colores desde claramente silenciados (blancos) a transformantes con fenotipos similares al tipo silvestre (rojos). Los transformantes se agruparon como colorless (fuertemente silenciados), pink (silenciados) y red (como el tipo silvestre). El porcentaje de fuertemente silenciados no varía entre estirpes (33,3\% y $35 \%)$ aunque varía ligeramente según el plásmido (35\% y 26,5\%) (Janus et al., 2007). Nuestro silenciamiento muestra mayores diferencias entre estirpes, pero el porcentaje medio de transformantes fuertemente silenciados es parecido (20,8\% y $31,6 \%)$. En otro caso, los transformantes silenciados en tres genes antioxidantes que codifican distintas superóxido dismutasas con sitios activos de Manganeso (Manganese-containing superoxide dismutase, MnSOD) en Phanerochaete chrysosporium, mostraban un rango variable de reducción de la actividad antioxidante MnSOD (del 6 al 70\%) y del nivel de transcrito (del 17 al 76\%). Variaciones en el nivel de transcrito en los transformantes silenciados también se han encontrado en Cryptococcus neoformans (Liu et al., 2002) y Trypanosoma brucei (Ngo et al., 1998).

Estas variaciones graduales en el fenotipo de los transformantes silenciados se 
han justificado en el contexto del lugar de integración ectópica (Mouyna et al., 2004). Sin embargo, construcciones que silencian dos genes distintos (uno chivato y otro diana) muestran niveles de transcritos y actividad distintos entre si, pese a estar integrados juntos en el genoma (Fitzgerald et al., 2004; Janus et al., 2007).

Los transformantes fueron cultivados en medios selectivos con diferentes fuentes de carbono, fuentes de nitrógeno y $\mathrm{pH}$. Observamos diferencias a los 3 días de crecimiento que desaparecen al cabo de 7 días. Existen diferencias entre las tasas de crecimiento de las estirpes del tipo silvestre y los transformantes silenciados en medio sin glucosa, en medio ácido $(\mathrm{pH} 4)$ y en medio sin nitrógeno, lo cual sugiere que los transformantes silenciados son más sensibles a estrés por carencia de nutrientes.

En estudios previos (Ramos, 2005) se observó que ftf2 presenta en algunas regiones una homología significativa con los factores de transcripción GAL4 (Pan \& Coleman, 1990), PPRI1 y MAL13 de $S$. cerevisiae (MacPherson et al., 2006), y LAC9 (Halvorsen et al., 1991) de Kluyveromyces lactis, involucrados en metabolismo nutricional (Todd \& Andrianopoulos, 1997). En F. oxysporum el factor de transcripción CTF1 regula la expresión de una cutinasa y una lipasa implicadas en hidrólisis de ácidos grasos durante el crecimiento. Como ftf2, la interrupción de su expresión no conlleva variaciones en la patogenicidad ni virulencia del hongo pero si en el crecimiento en varias fuentes de carbono (Rocha et al., 2008).
También como ftf2, no muestra variaciones de expresión durante la infección en planta.

Las estirpes silvestre crecen bien en medio ácido $(\mathrm{pH} 4), y$ gradualmente peor a medida que se incrementa el $\mathrm{pH}$ (comprobado en $\mathrm{pH} 6$ y $\mathrm{pH}$ 8). Los transformantes silenciados crecen en todos los $\mathrm{pH}$ de forma muy semejante a como lo hacen las estirpes silvestres en medio básico (pH 8), lo que sugiere algún tipo de alteración en la sensibilidad a la acidez del medio. La expresión de genes regulada según el pH del medio es una cascada de señalización compleja y conservada, cuyo componente terminal es el factor de transcripción pacC (Penalva \& Arst, 2002). En F. oxysporum, la disrupción de este gen causa alteraciones en el crecimiento y morfología de las colonias, asi como un incremento de la virulencia (Caracuel et al., 2003).

También se cuantificó la tasa de esporulación a los 3 y los 7 días. Algunos transformantes mostraban una reducción apreciable y significativa de la esporulación mientras que otros, aún mostrando reducción en el crecimiento, mostraban tasas de esporulación sólo ligeramente menores a la estirpe tipo silvestre y sin significación estadística. En los transformantes en los que la esporulación está reducida, ese grado de reducción de la esporulación es proporcional al de crecimiento. Por otro lado, haría falta ampliar el experimento a todos los transformantes para ver si se forman dos grupos diferenciables de forma similar a como sucede en el experimento de crecimiento. La relación entre la alteración del 
crecimiento y la esporulación se ha observado en otros casos, por ejemplo, tras la interrupción de algunos genes codificadores de subunidades de las proteinas-G, tales como FGA1 (Jain et al., 2002) y FGB2 (Delgado-Jarana et al., 2005), en cambio no se observa en FGA2 (Jain et al., 2005) ni FGB1 (Jain et al., 2003), pese a la semejanza funcional de todas estas subunidades de las proteínas-G.

Para comprobar si el silenciamiento de ftf2 tiene efecto sobre la virulencia realizamos un ensayo de infección comparando el aislado débilmente virulento FOP-SP4 (que no contiene ninguna copia de ftf1) con sus transformantes silenciados. El desarrollo de la enfermedad fue similar en todas las plantas, obteniéndose índices CIAT y D.P.R. semejantes para la estirpe FOP-SP4 y los correspondientes transformantes silenciados.

Los transformantes silenciados en $\mathrm{ftf2}$ conservan inalterada su capacidad patogénica pues se observa la sintomatología de la fusariosis vascular en las plantas. Por ello, podemos descartar que ftf2 sea un gen de patogenicidad. Esto concuerda con los datos de expresión de ftf2 en estirpes silvestres, donde no observamos diferencias en el perfil obtenido en crecimiento en medio de cultivo líquido y durante la infección en planta; ni entre aislados pertenecientes a diferentes grupos de virulencia.

El efecto sobre la virulencia también se comprobó en aislados supervirulentos y altamente virulentos. Se comparó la virulencia de seis transformantes supervirulentos claramente afectados en el crecimiento con la estirpe silvestre FOP-SP13, de la cual derivan. Dos transformantes (1.05 y 1.07) mostraron índices CIAT superiores a 7 tres semanas después de la infección, semejantes a los mostrados por la estirpe silvestre. Otros dos (1.06 y 1.09) mostraron un avance de la enfermedad más lento con índices CIAT inferiores a 6 tres semanas después de la infección. Sin embargo, dos de los transformantes (1.04 y 1.11) mostraron una sintomatología reducida desde la primera semana e índices CIAT iguales o inferiores a 4 en la tercera semana tras la infección. En el caso de los altamente virulentos, se probaron cuatro transformantes que mostraron una clara reducción del crecimiento. Tres de los transformantes $(2.06,2.07$ y 2.20$)$ no mostraron diferencias de virulencia con la estirpe silvestre FOP-SP01, de la cual derivan. Todos ellos alcanzaban valores en la escala CIAT superiores a 7 tres semanas después de la inoculación. En cambio, uno de los transformantes (2.08) mostró un desarrollo de la enfermedad más lento con índices CIAT inferiores a 5 en la tercera semana y claras diferencias con la estirpe silvestre a tiempos mayores. El calculo del D.P.R. (GarcíaSánchez, 2007) mostraba diferencias claras entre los distintos grupos propuestos, si bien un Análisis de la varianza no estimó significación estadística, probablemente por una desviación estandar alta. Al igual que en el estudio de virulencia de las estirpes aisladas de judión, el índice D.P.R. demuestra ser una buena herramienta para diferencias estirpes con distinta agresividad. 
De forma similar a como sucedía con el crecimiento, se aprecia un gradiente en las diferencias fenotípicas de los transformantes silenciados. Todos los transformantes probados mostraban una reducción importante del crecimiento y fueron catalogados como fuertemente silenciados, pese a ello no todos mostraron una alteración de la virulencia tan clara.

El dramático incremento de expresión de ftf1 a las 24 horas tras la infección (Ramos et al., 2007) ya sugería un papel relevante de este gen durante la infección. Sin embargo, la confirmación del papel de ftf1 en virulencia no se pudo aseverar hasta comprobar que los transformantes silenciados en ftf1 y ftf2 mostraron reducción de la virulencia, mientras que los transformantes silenciados en $f t f 2$ no.

Aún los transformantes silenciados en ftf1 y ftf2 que mostraron menos virulencia, también mostraron claros síntomas de la enfermedad, esto es, conservaban la capacidad patogénica. Esto se puede deber a que ftf1 no es fundamental para la patogenicidad $\circ$ porque los aislados silenciados conservan una expresión residual de ftf1. Nos decantamos por la primera opción porque se han descrito aislados en los que no está presente ftf1 que son patógenos, como algunos aislados de $F$. oxysporum f.sp. pini o f.sp melonis usados en este trabajo. Tampoco está presente ftf1 en algunas estirpes de F. oxysporum f.sp. phaseoli, como por ejemplo las débilmente virulentas (Ramos, 2005; Ramos et al., 2007).
Al igual que sucede con ftf1, encontramos ejemplos de genes en los que la disrupción causa una perdida de virulencia conservando la patogenicidad. El gen ChsVb es una quitinsintasa (la quitina es un componente menor pero fundamental del pared fúngica) y su disrupción ocasiona crecimiento aberrante, debilidad estructural e incapacidad para infectar y colonizar tomate \{Martin-Urdiroz, 2008 \#189\}. En otro caso, la disrupción del gen FoSNF1 (homologo a SNF1 de $S$. cerevisae que regula el metabolismo secundario de carbono) causa un crecimiento alterado en fuentes secundarias de carbono y una reducción de la virulencia (Ospina-Giraldo et al., 2003). Análogamente, la inactivación del regulador genérico de nitrógeno $F n r 1$ en $F$. oxysporum conlleva una perdida en la capacidad de usar distintas fuentes de nitrógeno, elimina la expresión de genes de nutrición y afecta a la virulencia alterando la inducción de genes necesarios para la adaptación a las condiciones pobres en nitrógeno tras la entrada en la planta (Divon et al., 2006; Divon \& Fluhr, 2007). En ambos ejemplos, parece que la incapacidad para un aprovechamiento eficiente de los recursos nutricionales, escasos en el interior de la planta en alguna de las fases de la infección (Solomon et al., 2003), supone una reducción de la agresividad y causa un perdida de virulencia, y sugieren una relación entre algunos genes de virulencia (que no de patogenicidad) y la capacidad a los nutrientes disponibles dentro de la planta. 
A diferencia de $f t f 1$, se han descrito casos en los que la interrupción de algunos genes expresados durante la infección sí causa la perdida completa de la capacidad patogénica. Esto puede ayudar a descartar funciones de ftf1. En $F$. oxysporum, la disrupción del factor de transcripción $\mathrm{Zn}(\mathrm{II})_{2} \mathrm{Cys}_{6}$ denominado FOW2 causa una perdida completa de patogenicidad: FOW2 no está implicado en crecimiento vegetativo, conidiación ni utilización de fuentes de carbono, pero es esencial para la colonización de los haces vasculares de la planta (Imazaki et al., 2007). En otro ejemplo, el gen FMK1 codifica una MAP quinasa y su interrupción afecta a la adhesión e infección de la raíz suprimiendo la capacidad patogénica pero no afecta ni al crecimiento ni a la conidiación (Di Pietro et al., 2001). También en $F$. oxysporum, la interrupción del gen FRP1 implicado en la regulación de proteínas involucradas en patogenicidad, causa una perdida de la patogenicidad por perdida de la capacidad de adhesión de los conidios a la raíz pero no afecta ni a la producción de esporas ni a la viabilidad de las mismas. Además, homólogos a FRP1 están presentes en un número significativo de hongos (Duyvesteijn et al., 2005). En cambio, cuando se interrumpe el gen chs $V$ implicado en la resistencia a antimicrobianos e integridad de la pared celular, se producen alteraciones morfológicas y se pierde completamente la capacidad de infección (Madrid et al., 2003). Excepto en este último caso, la perdida de patogenicidad no iba asociada a otros efectos fenotípicos sobre el desarrollo.

La interrupción de algunos genes claramente expresados durante la infección, a diferencia de lo que sucede en $f t f 1$, no causa fenotipos afectados en virulencia ni patogenicidad, lo que también puede ayudar a descartar funciones de $\mathrm{ftf1}$. Como muchos otros hongos, $F$. oxysporum secreta un variado conjunto de enzimas de degradación de la pared celular (CWDE) durante la penetración y colonización (Beckman, 1987). La interrupción o delección de algunos genes codificadores de enzimas líticas, que se expresan durante la infección en planta, como genes de endopoligalacturonasas (pg1, pg5), exopoligalacturonasas (pgx4), pectato liasas (p/1) o endoxilanasas (xy/3, xyl4, xyl 5) (Di Pietro et al., 2003; Michielse \& Rep, 2009), no produce una pérdida apreciable de la virulencia, probablemente por las funciones redundates de la mayoría de estas enzimas (Idnurm \& Howlett, 2001; Di Pietro et al., 2003). Un resultado parecido se obtuvo al interrumpir el gen codificador del factor de transcripción XInR activador de los cuatro genes presentes en $F$. oxysporum codificadores de xilanasas (Calero-Nieto et al., 2007). Se comprobó cierta pérdida de actividad xilanásica, pero sin reducción de la virulencia, probablemente porque la actividad residual es suficiente para mantener ésta. Se ha observado el mismo resultado con la interrupción de los genes codificadores de xilanasas en otros hongos como Cochliobolus carbonum (Apel-Birkhold \& Walton, 1996) y Magnaporthe grisea (Wu et 
al., 2006). Si ftf1 regulase la acción directa de un grupo de enzimas liticas de pared, el carácter redundante de las mismas no conllevaría una reducción de la virulencia. Además, la sobreexpresión de una enzima de degradación de pared no parece que pueda suponer una ventaja suficiente (precisamente por ese carácter redundante de las mismas) para explicar las diferencias tan claras que observamos entre estirpes silvestres supervirulentas y altamente virulentas (con ftf1) respecto a las débilmente virulentas (sin ftf1); sin embargo, podría ser que ftf1 regulase de forma absoluta una familia enzimática completa, en cuyo caso si podrían obtenerse mayores diferencias.

El fenotipo de los transformantes y la comprobación experimental de la existencia de genes con la expresión reprimida en dos transformantes silenciados en $\mathrm{ftf2}$ verifican la existencia de un silenciamiento. Sin embargo, la expresión relativa de los genes ftf1 y ftf2 en los transformantes silenciados calculada mediante PCR cuantitativa en tiempo real no muestra una reducción en todos los casos cuando se compara con la de los aislados silvestres. Al contrario, en la mayoría de los casos los transformantes muestran tasas de transcritos de los genes ftf1 y ftf2 superiores a las detectadas en los aislados silvestres. Nuestra hipótesis es que hemos encontrado un proceso de amplificación del silenciamiento a partir de la generación de siRNA secundarios de forma similar al presente en plantas y Caenorhabditis spp. (Voinnet, 2008; Ghildiyal \& Zamore, 2009). Las enzimas clave en la producción de siRNA secundarios son las ARN polimerasas dependientes de ARN (RdRP). En $F$. graminearum se han identificado al menos cuatro proteínas RdRP, nombradas RdRP1, RdRP2, RdRP3 por su homología con otras RdRP de otros hongos. Una cuarta RdRP tiene una homología menor. (Nakayashiki et al., 2006). En F. oxysporum hemos localizado cuatro ORFs homologas a los anteriores (11123, 16453, 02461 y 03081, respectivamente) cuya actividad podría permitir la generación de siRNA secundarios.

Hemos encontrado algunos ejemplos en los que se describen tasas superiores de transcrito en los transformantes silenciados que en el tipo silvestre, sin que este fenómeno se explique claramente. En el hongo Phanerochaete chrysosporium, la principal respuesta del sistema antioxidante en respuesta a ROS consiste en incrementar la expresión de las proteínas MnSOD (Manganese-containing superoxide dismutase). Tras el silenciamiento con una secuencia diana común a los tres genes MnSOD que existen en el genoma de $P$. chrysosporium, uno de los cuatro transformantes silenciados (MSC1) que tenía la mayor reducción de la actividad antioxidante MnSOD, mostraba 4 veces mas transcrito en dos de los genes MnSOD y un $50 \%$ de la expresión en el restante. En cambio, los transformantes que mostraban una cantidad de proteína parecida al tipo silvestre mostraban una cantidad de transcrito mucho menor (Matityahu et al., 2008). En otro caso, seis de los once transformantes obtenidos mostraban 
mayores niveles de transcrito que el tipo silvestre, pero estos transformantes mostraban un fenotipo similar al tipo silvestre (Fitzgerald et al., 2004). Se comprueba también que la tasa de expresión puede variar según los cebadores usados en la cuantificación. Cuando la expresión relativa en tiempo real se ha medido en la región usada en la construcción de silenciamiento el nivel de transcrito detectado es mayor. El incremento puede explicarse por la detección directa del ARN transcrito a partir del plásmido (hsRNA) bajo el control de promotor de ToxA, que es fuerte y constitutivo. También puede deberse a los propios promotores, como se ha observado en la cuantificación del silenciamiento del gen THN en Venturia inaequalis utilizando dos pares de oligonucleótidos (Fitzgerald et al., 2004), o en el estudio más detallado en células humanas realizado por el fabricante BioRad (Maerken et al., 2009).

\section{6 - La identificación de los genes presuntamente} regulados por $\mathrm{ftf}$, sugiere que podría tener un papel en el metabolismo de nutrientes

A fin de indagar sobre la posible función de los genes ftf1 y ftf2, decidimos identificar genes regulados por ftf2, puesto que el sistema experimental ya había sido puesto a punto en este trabajo. Para ello y mediante hibridación substractiva (SSH), comparamos los transcritos sintetizados tras 24 horas de crecimiento en cultivo líquido de la estirpe silvestre débilmente virulenta SP4, que no tiene el gen $f t f 1$, y el transformante silenciado derivado de ella 3.01. Secuenciamos 60 clones de los que obtuvimos 46 secuencias, 18 de las cuales correspondieron a ORFs diferentes. De ellas, seleccionamos 12 por comparación con el genoma de $F$. oxysporum, para someterlas a un estudio de la expresión mediante Realtime PCR, en el cual se compararon las expresiones relativas de estos presuntos genes en la estirpe FOP-SP4 y el transformante 3.01 a las 48 horas, y entre la estirpe FOP-SP4 y el transformante 3.15 a las 24 horas.

Todos los genes expresados diferencialmente analizados se expresaban menos en los dos transformantes (3.01 y 3.15) y distintos tiempos (24 y 48 horas de crecimiento en cultivo líquido). El rango de expresión de cada presunto gen respecto al tipo silvestre varía entre el $20 \%$ y el $70 \%$, y sólo en dos casos la expresión en FOP-SP4 y un transformante silenciado es muy parecida (“TFFID" en 3.15 a las 24 horas y "TAUD" en 3.01 a las 48 horas). De esto se deduce que ftf2 funciona principalmente como un activador de otros genes. Salvo contadas excepciones (UME6 y LEU3) (Park et al., 1992; Sze et al., 1993), las proteínas que tienen un dominio dedo de zinc binuclear $\mathrm{Zn}(\mathrm{II})_{2} \mathrm{Cys}_{6}$ actúan como activadores (Todd \& Andrianopoulos, 1997; MacPherson et al., 2006), por ejemplo en Fusarium spp. (Proctor et al., 1995; Flaherty \& Woloshuk, 2004), Colletotrichum lagenarium (Tsuji et al., 2000), Neurospora crassa (Fu \& Marzluf, 1990; Yuan et al., 1991; Fu et al., 1995) o Aspergillus spp. (Suárez et al., 1995; Hasper et al., 2004). 
El número de clones correspondientes a la misma ORF presentes en la genoteca substractiva es indicativo del grado de diferencia entre las dos poblaciones de transcritos que se comparan, y no de la cantidad de transcrito presente (Diatchenko et al., 1996). Por ello, podemos suponer que aquellos genes que aparecen más frecuentemente son los que están más estrictamente regulados por ftf2. Aparentemente, el número de genes regulados por $\mathrm{ftf} 2$ no es muy grande porque solo encontramos 18 ORFs distintas pese a alcanzar un nivel de redundancia en el que el $60 \%$ de los clones secuenciados eran repeticiones.

Los 12 genes para los que hemos verificado su expresión diferencial (y suponemos su regulación por ftf2) están implicados en procesos básicos como la regulación de la traducción y la acción enzimática en rutas fundamentales. Sin embargo, más de uno de cada diez clones secuenciados correspondían a una ORF codificadora de una proteína desconocida que hemos nombrado 04611. Probablemente, elucidar la función de esta proteína desconocida nos ayude a comprender definitivamente la función de ftf2.

Uno de los genes que disminuye su expresión en los transformantes silenciados en ftf2 es homólogo al gen SIP5 presente en varios hongos, que está involucrado en respuesta a estrés nutricional. En concreto, SIP5 está implicado en crecimiento con fuentes de carbono diferentes a glucosa (Hedbacker \& Carlson, 2008) pues regula negativamente la kinasa SNF1 (Sanz et al., 2000). La interrupción de SNF1 en $F$. oxysporum resulta en un crecimiento reducido en diferentes fuentes de carbono $y$ reducción de la virulencia (Ospina-Giraldo et al., 2003). En F. graminearum (Gibberella zeae) los mutantes interrumpidos en el gen SNF1 (GzSNF1) mostraron reducción de crecimiento, de virulencia y alteración en la germinación de ascosporas y conidios (Lee et al., 2009), al igual que ocurre en $M$. oryzae (MoSNF1) (Yi et al., 2008). Los transformantes silenciados en ftf2 presentan un fenotipo parecido a los disruptantes SNF1. Esto sugiere que ftf2 podría tener un papel en el metabolismo secundario de carbono, por analogía con SNF1.

Otros genes abundantemente representados en la genoteca diferencial (más de tres clones) son aquellos que codifican para una piruvato descarboxilasa, una aspartil proteasa y dos reguladores de respuesta abiótica: uno a estrés nutricional y otro a estrés respiratorio (proteína de respuesta a hipoxia). Estos dos últimos sugieren una vinculación con respuesta a situaciones de estrés. La piruvato descarboxilasa (pdcA) tiene un dominio de unión a trifosfato de tiamina (Vitamina B1), que actúa como coenzima en el metabolismo de hidratos de carbono. En levaduras está ampliamente descrita la regulación de las proteínas piruvato descarboxilasas en función del oxígeno y fuente de carbono; y está presente en la mayor parte de hongos filamentosos $(F$. oxysporum, C. globosum, $P$. anserina, $B$. fuckeliana). En los ascomicetos $N$. crassa 
(Alvarez et al., 1993) y A. nidulans (Lockington et al., 1997), y en el zigomiceto Rhizopus oryzae (Skory, 2003) se ha descrito la activación de $p d c A$ como ruta energética residual y en presencia de glucosa durante periodos de estrés anaeróbico (Skory, 2003). En relación con este último caso, como hemos comentado, uno de los genes más representados en la genoteca diferencial es un regulador de respuesta a condiciones de hipoxia.

Todos estos datos nos permiten apuntar un probable función de ftf2 en la respuesta a estrés por limitación de carbono o condiciones de hipoxia. Esta hipótesis se apoya también en los resultados de crecimiento selectivo donde las mayores diferencias entre tipos silvestres $y$ transformantes silenciados se obtenían en medio sin fuente de glucosa y en medio sin fuente de nitrógeno.

Finalmente, uno de los genes que muestra menor expresión en los transformantes silenciados en ftf2 es una aspartil proteasa homologa a una descrita (SA76) en $T$. harzianum. SA76 sobreexpresado en $S$. cerevisiae causa reducción en el crecimiento de varios hongos filamentosos, cual apoya su papel como CWDE (Liu \& Yang, 2007).

Durante el crecimiento, múltiples enzimas están implicadas en el metabolismo de fuentes secundarias de carbono (arabinosa, sacarosa, galactosa, maltosa, etc.). Se ha observado que la actividad de estas enzimas se inhibe en presencia de carbono (Carlson et al., 1981). Esta misma regulación negativa en presencia de la glucosa actúa sobre múltiples enzimas (XYL1, XYL2, XYL3, XYL4, XYP1, ARF1, MLG1, EXG1, PGN1 y PGX1) implicadas en la degradación de la pared durante la infección (Tonukari et al., 2000). Si nuestra hipótesis acerca de la relación de ftf2 con el metabolismo del carbono durante el crecimiento en situaciones de estrés es correcta, por analogía estructural con ftf2, el gen ftf1 podría tener un papel en la regulación de CWDE en las etapas tempranas del proceso de infección. Para comprobar esta hipótesis resulta prioritario desarrollar un sistema experimental in vitro para comparar las poblaciones de transcritos en un fondo genético muy virulento con otro silenciado en ftf1. Si esta comparación verifica un papel en la regulación de CWDE, también sería interesante elucidar si las múltiples copias de ftf1 tienen un papel redundante o bien puede haber cierta especificidad en las CWDE reguladas. 


\section{Conclusiones}



1. - We have characterized a new virulence group composed by supervirulent strain of $F$. oxysporum f.sp. phaseoli obtained from Phaseolus coccineous disseased plants.

2. - All the supervirulent strains harbour an additional copy of the gene ftf1. However, some highly and weakly virulent strains also show this extra copy. Gene expression analyses carried out in bean plants inoculated with supervirulent strains show a higher upregulation of $f t f 1$ than that observed when inoculations were performed with highly virulent strains, which suggests that the extra copy is functional.

3. - The gene ftf2 is a transcription factor with an activator role, as supported by the finding that all the genes supposedly regulated by ftf2 showed a smaller expression in the ftf2 silenced transformants than in the wild-type strain.

4. - The expression of gene ftf2 is mainly constant in time, both in mycelium grown in axenic cultures or in inoculated plants. This expression pattern is characteristic of constitutive genes.

5.- The transcript levels of gene $\mathrm{ftf} 2$ detected in RNAi mutants, as measured by Real-time PCR, can not be correlated with the corresponding phenotypic alteration degree. We do not have a clear explanation to this finding, but it could be due to secondary amplifications related to the gene silencing mechanism, as it has been shown in plants.
6. - The gene ftf2 seems to be important for regular growth and sporulation, because silenced transformants show a significant reduction of the growth and sporulation rates.

7. - Some evidences seem to indicate that ftf2 could be involved in metabolism adaptation to nutrient stress conditions, because the higher growth differences between silenced transformants and the wildtype strains were found at early stages of growth in media with no carbon or nitrogen sources at shorter times. Also, two of the genes supposedly regulated by $f t f 2$ are involved in stress response.

8. - A possible role of $\mathrm{ftf} 2$ in pathogenicity or virulence may be ruled out by the following evidences: a) ftf2 is present in non-pathogenic $F$. oxysporum strains, and also in other non-pathogenic fungi; b) ftf2 expression is basically the same in strains of different virulence groups, an also when the strains are grown under axenic culture conditions or during plant infection; and c) silenced transformants did not show loss of pathogenicity or virulence variations when compared with the wild-type strains.

9. - The gene ftf1 is a virulence factor in F. oxysporum. We have confirmed that $f t f 1$ expression is dramatically upregulated during infection of common bean plants. Also, ftf1 and ftf2 silenced transformants show phenotypes from moderate to significantly 
reduced in virulence, as shown in common bean plants inoculated with $F$. oxysporum f.sp. phaseoli strains and in tomato plants inoculated with F. oxysporum f.sp. lycopersici strains.

10. - The gene ftf1 is present in a variable number of copies, this number showing no correlation with the geographic origin or the formae especiales of the considered strain. However, we have found some evidence in favour of a positive correlation between a higher copy number and ftf1 transcript level.

11. - There is a linkage between the ftf1 copies detected in the sequenced genome of strain 4287 of $F$. oxysporum f.sp. lycopersici and the transposon Impala, similar to the relationship previously found between transposon Marsu and the ftf1 copies in $F$. oxysporum f.sp. phaseoli strains. This linkage relationship strongly suggests a role for transposons in the duplication of ftf1 or gene ftf1 transfers.

12. - The homology between the ftf1 sequences present in the strains analyzed in this work is not correlated with formae especiales, thus confirming that most formae speciales in $F$. oxysporum do not have a polyphyletic origin. In this context, ftf1 copy homology could be an indicator of a common origin for isolates that have evolved to become specific to different hosts and/or gene transfer events. 
1. - Hemos caracterizado un nuevo grupo de virulencia formado por estirpes supervirulentas de $F$. oxysporum f.sp. phaseoli, obtenidas de Phaseolus coccineus con sintomatología de Fusariosis vascular.

2. - Todas las estirpes supervirulentas contienen una copia adicional del gen ftf1. Sin embargo, algunas estirpes altamente y débilmente virulentas también muestran esta copia extra. Los análisis de expresión llevados acabo en plantas de judía inoculadas con estirpes supervirulentas revelan una mayor expresión de ftf1 que la observada en las plantas inoculadas con estirpes altamente virulentas, lo que sugiere que esta copia adicional es funcional.

\section{3. - El gen ftf2 es un factor de} transcripción con un papel activador, ya que todos los genes presuntamente regulados por ftf2 muestran una menor expresión en los transformantes silenciados en ftf2 que en la estirpe silvestre.

4. - La expresión de ftf2 es básicamente constante en el tiempo, tanto durante el crecimiento en medio líquido como en plantas inoculadas. Este patrón de expresión es característico de genes constitutivos.

5. - El nivel de transcrito de ftf2 acumulado en los transformantes silenciados, cuantificado mediante PCR cuantitativa en tiempo real, no es indicativo del grado de alteración del fenotipo correspondiente. No tenemos una explicación clara para este fenómeno, aunque podría deberse a fenómenos de amplificación implicados en silenciamiento, como ya se ha descrito en plantas.

6. - El gen $\mathrm{ftf2}$ parece ser fundamental para el crecimiento y la esporulación, ya que los transformantes silenciados muestran una reducción significativa de las tasas de crecimiento y esporulación.

7. - Algunas evidencias sugieren que ftf2 podría estar implicado en la adaptación metabólica a condiciones de estrés nutricional, debido a que las mayores diferencias de crecimiento entre los transformantes silenciados y las estirpes silvestres se encontraron a tiempos cortos en medios carentes de fuentes de carbono o nitrógeno. Además, dos de los genes supuestamente regulados por ftf2 están implicados en respuesta a estrés.

8. - La implicación de ftf2 en patogenicidad o virulencia puede descartarse por las siguientes evidencias: a) ftf2 está presente en estirpes no patógenas de $F$. oxysporum y en otros hongos no patógenos; b) la expresión de ftf2 es básicamente la misma en estirpes pertenecientes a distintos grupos de virulencia, y tanto durante el crecimiento en medios de cultivo como durante la infección en planta; y c) los transformantes silenciados no mostraron variación en la virulencia respecto de la estirpe silvestre. 
9. - El gen ftf1 es un factor de virulencia en $F$. oxysporum. Hemos confirmado que la expresión de ftf1 se incrementa drásticamente durante la infección de plantas de judía. Además, los transformantes silenciados en ftf1 muestran una reducción de virulencia tanto en plantas de judía infectadas con F. oxysporum f.sp. phaseoli como en plantas de tomate infectadas con F. oxysporum f.sp. lycopersici.

10. - El gen ftf1 está presente en un número de copias variable, y sin que este número presente correlación ni con el origen geográfico ni con la forma especial de la estirpe considerada. Sin embargo, hemos encontrado evidencias en favor de una relación positiva entre un mayor número de copias y el nivel de transcrito de ftf1.

11. - Existe una relación entre las copias de ftf1 detectadas en el genoma secuenciado de la estirpe 4287 de $F$. oxysporum f.sp. lycopersici y el transposon Impala, semejante a la descrita anteriormente entre el transposon Marsu y las copias de ftf1 presentes en F. oxysporum f.sp. phaseoli. Esta relación apoya un papel importante de los transposones en la duplicación o transmisión de las copias de ftf1.

12. - La homología entre las secuencias de ftf1 presentes en las estirpes analizadas en este trabajo no se corresponde con las formas especiales a las que pertenecen, confirmando que muchas formas especiales no tienen un origen polifilético. El gen ftf1 podría ser un indicador del origen común de estirpes que han evolucionado adaptándose a distintos hospedadores y/o de eventos de transferencia de genes. 


\section{7 \\ Bibliograff́a}



Agrios GN. 1997. Plant pathology. Harcourt/Academic Press. BurlingtonEEUU.

Ahn JH, Cheng YQ, Walton JD. 2002. An extended physical map of the tox2 locus of cochliobolus carbonum required for biosynthesis of hc-toxin. Fungal Genet Biol 35: 31-38.

Akiyama M, Nakashima H. 1996. Molecular cloning of the acr-2 gene which controls acriflavine sensitivity in neurospora crassa. Biochem Biophys Acta 1307: 187-192.

Aloj B, Marziano F, Zoina A, Noviello C. 1983. La tracheofusariosi del fagiolo in italia. Informatore fitopatologico 11/83: 63-66.

Alvarez ME, Rosa AL, Temporini ED, Wolstenholme A, Panzetta G, Patrito L, Maccioni HJ. 1993. The 59-kda polypeptide constituent of $8-10-\mathrm{nm}$ cytoplasmic filaments in neurospora crassa is a pyruvate decarboxylase. Gene 130: 253-258.

Alves-Santos F, Cordeiro-Rodrigues L, Sayagues J, Martin-Rodriguez R, Garcia-Benavides P, Crespo M, Diaz-Miguez J, Eslava A. 2002. Pathogenicity and race characterization of fusarium oxysporum f.Sp. Phaseoli isolates from spain and greece. Plant pathology 51: 605-611.

Alves-Santos F, Ramos B, García-Sánchez MA, Eslava AP, Diaz-Miguez JM. 2002. A DNA-based procedure for inplanta detection of fusarium oxysporum f.Sp. Phaseoli.

Phytopathology 92: 237-244.

Alves-Santos FM, Benito EP, Eslava AP, Díaz-Mínguez JM. 1999. Genetic diversity of fusarium oxysporum strains from common bean fields in spain. Appl Environ Microbiol 65: 3335-3340.

Apel-Birkhold PC, Walton JD. 1996. Cloning, disruption, and expression of two endo-beta 1, 4-xylanase genes, xyl2 and $x y l 3$, from cochliobolus carbonum. Appl Environ Microbiol 62: 4129-4135.

Appel DJ, Gordon TR. 1995. Intraspecific variation within populations of fusarium oxysporum based on rflp analysis of the intergenic spacer region of the rdna. Exp Mycol 19: 120-128.

Arie T, Kaneko I, Yoshida T, Noguchi M, Nomura Y, Yamaguchi I. 2000. Mating-type genes from asexual phytopathogenic ascomycetes fusarium oxysporum and alternaria alternata. Mol Plant Microbe Interact 13: $1330-1339$.

Armstrong GM, Armstrong JK 1981. Formae speciales and races of fusarium oxysporum causing wilt diseases. En Fusarium: Diseases, biology and taxonomy, 391-399.

\section{Baayen RP, O'Donnell K, Bonants PJ,} Cigelnik E, Kroon LP, Roebroeck EJ, Waalwijk C. 2000. Gene genealogies and aflp analyses in the fusarium oxysporum complex identify monophyletic and nonmonophyletic formae speciales causing wilt and rot 
disease. Phytopathology 90: 891-900.

Balzi E, Chen W, Ulaszewski S, Capieaux

E, Goffeau A. 1987. The multidrug resistance gene pdr1 from saccharomyces cerevisiae. J Biol Chem 262: 16871-16879.

Beckman CH. 1987. The nature of wilt diseases of plants. Amer Phytopathological Society. EEUU.

Benlloch M, Cañizo JD. 1926. La enfermedad de las alubias en barco de ávila. Boletín de la Estación de Patología Vegetal 1: 2-7.

Bethke PC, Libourel IG, Jones RL. 2006. Nitric oxide reduces seed dormancy in arabidopsis. J Exp Bot 57: 517-526.

Biemelt S, Sonnewald U. 2006. Plantmicrobe interactions to probe regulation of plant carbon metabolism. J Plant Physiol 163: 307-318.

Booth C. 1971. The genus fusarium.

Bosland MC. 1988. The etiopathogenesis of prostatic cancer with special reference to enviromental factors. Adv. Cancer Res. 51: 1-106.

Cai G, Gale LR, Schneider RW, Kistler HC, Davis RM, Elias KS, Miyao EM. 2003. Origin of race 3 of fusarium oxysporum f. Sp. Lycopersici at a single site in california. Phytopathology 93: 10141022.

Calero-Nieto F, Di Pietro A, Roncero MI, Hera C. 2007. Role of the transcriptional activator $x \ln r$ of fusarium oxysporum in regulation of xylanase genes and virulence. $\mathrm{Mol}$ Plant Microbe Interact 20: 977-985.
Canero DC, Roncero MI. 2008. Functional analyses of laccase genes from fusarium oxysporum. Phytopathology 98: 509-518.

Caracuel Z, Martinez-Rocha AL, Di Pietro A, Madrid MP, Roncero MI. 2005. Fusarium oxysporum gas1 encodes a putative beta-1,3glucanosyltransferase required for virulence on tomato plants. Mol Plant Microbe Interact 18: 1140-1147.

Caracuel Z, Roncero MI, Espeso EA, Gonzalez-Verdejo $\mathrm{Cl}$ GarciaMaceira FI, Di Pietro A. 2003. The ph signalling transcription factor pacc controls virulence in the plant pathogen fusarium oxysporum. Mol Microbiol 48: 765-779.

Carlson M, Osmond BC, Boltstein D. 1981. Mutants of yeast defective in sucrose utilization. Genetics 98: 25-40.

Ciuffetti LM, Tuori RP, Gaventa JM. 1997. A single gene encodes a selective toxin causal to the development of tan spot of wheat. Plant Cell 9: 135-144.

Cook RJ. 1998. The molecular mechanisms responsible for resistance in plantpathogen interactions of the gene-forgene type function more broadly than previously imagined. Proc Natl Acad Sci U S A 95: 9711-9712.

\section{Coppin E, Debuchy R, Arnaise S, Picard M.} 1997. Mating types and sexual development in filamentous ascomycetes. Microbiol Mol Biol Rev 61: 411-428.

Correll JC, Klittich CJR, Leslie JF. 1987. 
Nitrate nonutilizing mutants of fusarium oxysporum an their use en vegetative comàtibility tests. Phytopathology $\mathbf{7 7}$ : 1640-1646.

Cuomo CA, Guldener U, Xu JR, Trail F, Turgeon BG, Di Pietro A, Walton JD, Ma LJ, Baker SE, Rep M, Adam G, Antoniw J, Baldwin T, Calvo $\mathrm{S}$, Chang YL, Decaprio D, Gale LR, Gnerre S, Goswami RS, HammondKosack K, Harris LJ, Hilburn K, Kennell JC, Kroken S, Magnuson JK, Mannhaupt G, Mauceli E, Mewes HW, Mitterbauer R, Muehlbauer G, Munsterkotter M, Nelson D, O'Donnell K, Ouellet T, Qi W, Quesneville H, Roncero MI, Seong KY, Tetko IV, Urban M, Waalwijk C, Ward TJ, Yao J, Birren BW, Kistler HC. 2007. The fusarium graminearum genome reveals a link between localized polymorphism and pathogen specialization. Science 317: 14001402.

Daboussi MJ, Capy P. 2003. Transposable elements in filamentous fungi. Annu Rev Microbiol 57: 275-299.

Dangl JL, Jones JD. 2001. Plant pathogens and integrated defence responses to infection. Nature 411: 826-833.

Davies DLG. 1942. A fusarium wilt of runner bean. Trans. Br. mycol. Soc. 25: 418426.

Delgado-Jarana J, Martinez-Rocha AL, Roldan-Rodriguez R, Roncero MI, Di Pietro A. 2005. Fusarium oxysporum g-protein beta subunit fgb1 regulates hyphal growth, development, and virulence through multiple signalling pathways. Fungal Genet Biol 42: 6172.

Desjardins AE. 2003. Gibberella from a (venaceae) to $\mathrm{z}$ (eae). Annu Rev Phytopathol 41: 177-198.

Desjardins AE, Hohn TM, McCormick SP. 1993. Trichothecene biosynthesis in fusarium species: Chemistry, genetics, and significance. Microbiol Rev 57: 595-604.

Di Pietro A, Garcia-MacEira FI, Meglecz E, Roncero MI. 2001. A map kinase of the vascular wilt fungus fusarium oxysporum is essential for root penetration and pathogenesis. $\mathrm{Mol}$ Microbiol 39: 1140-1152.

Di Pietro A, Madrid MP, Caracuel Z, Delgado-Jarana J, Roncero MI. 2003. Fusarium oxysporum: Exploring the molecular arsenal of a vascular wilt fungus. Molecular Plant Pathology 4: $315-321$

Diatchenko L, Chris-Lau YF, Campbell AP, Chenchik A, Moqadam F, Huang B, Lukyanov S, Lukyanov K, Gurskaya N, Sverdlov ED, Siebert PD. 1996. Suppression subtractive hybridization: A method for generating differentially regulaed or tissue-specific cdna probes and libraries. Proc Natl Acad Sci U S A 93: 6025-6030.

Díaz-Mínguez JM, Alves-Santos F, Benito EP, Eslava AP. 1996. Fusarium wilt of common bean in the castilla y leon region of spain. Plant Disease 80: 600. 
Divon HH, Fluhr R. 2007. Nutrition acquisition strategies during fungal infection of plants. FEMS Microbiol Lett 266: 6574.

Divon HH, Ziv C, Davydov O, Yarden O, Fluhr R. 2006. The global nitrogen regulator, fnr1, regulates fungal nutrition genes and fitness during fusarium oxysporum pathogenesis. Molecular Plant Pathology 7: 485-497.

Dixon MS, Hatzixanthis $K$, Jones DA, Harrison K, Jones JD. 1998. The tomato cf-5 disease resistance gene and six homologs show pronounced allelic variation in leucine-rich repeat copy number. Plant Cell 10: 19151925.

Dodds PN, Lawrence GJ, Catanzariti AM, Ayliffe MA, Ellis JG. 2004. The melampsora lini avrl567 avirulence genes are expressed in haustoria and their products are recognized inside plant cells. Plant Cell 16: 755-768.

DuTeau NM, Leslie JF. 1991. A simple, rapid procedure for the isolation of DNA for pcr from gibberella fujikuroi (fusarium section liseola). Fungal Genet Newsletter 38: 72.

Duyvesteijn RG, van Wijk R, Boer Y, Rep M, Cornelissen BJ, Haring MA. 2005. Frp1 is a fusarium oxysporum f-box protein required for pathogenicity on tomato. Mol Microbiol 57: 1051-1063.

Edgar RC. 2004. Muscle: A multiple sequence alignment method with reduced time and space complexity. BMC Bioinformatics 5: 113.
FAOSTAT. 2004. Dry bean production. FAO.

Fekete C, Nagy R, Debets AJ, Hornok L. 1993. Electrophoretic karyotypes and gene mapping in eight species of the fusarium sections arthrosporiella and sporotrichiella. Curr Genet 24: 500504.

Fitzgerald A, Van Kan JA, Plummer KM. 2004. Simultaneous silencing of multiple genes in the apple scab fungus, venturia inaequalis, by expression of rna with chimeric inverted repeats. Fungal Genet Biol 41: 963-971.

Flaherty JE, Woloshuk CP. 2004. Regulation of fumonisin biosynthesis in fusarium verticillioides by a zinc binuclear cluster-type gene, zfr1. Appl Environ Microbiol 70: 2653-2659.

Flor HH. 1956. The complementary genic systems in flax and flax rust. $A d v$. in Genetics 8: 29-54.

Fotopoulos V, Gilbert MJ, Pittman JK, Marvier AC, Buchanan AJ, Sauer N, Hall JL, Williams LE. 2003. The monosaccharide transporter gene, atstp4, and the cell-wall invertase, atbetafruct1, are induced in arabidopsis during infection with the fungal biotroph erysiphe cichoracearum. Plant Physiol 132: 821-829.

Friden P, Reynolds C, Schimmel P. 1989. A large internal deletion converts yeast leu3 to a constitutive transcriptional activator. Mol Cell Biol 9: 4056-4060.

Fu YH, Feng B, Evans S, Marzluf GA. 1995. 
Sequence-specific DNA binding by nit4, the pathway-specific regulatory protein that mediates nitrate induction in neurospora. Mol Microbiol 15: 935942.

Fu YH, Marzluf GA. 1990. Nit-2, the major positive-acting nitrogen regulatory gene of neurospora crassa, encodos a sequence-specific DNA-binding protein. Proc Natl Acad Sci U S A 87: 5331-5335.

García-Sánchez MA. 2007. Aislamiento y caracterización de los genes fost12 y fost20 en el hongo fusarium oxysporum f.Sp. Phaseoli. Tesis Doctoral. Universidad de Salamanca.

Ge W, Chew TG, Wachtler V, Naqvi SN, Balasubramanian MK. 2005. The novel fission yeast protein pal1p interacts with hip1-related sla2p/end4p and is involved in cellular morphogenesis. Mol Biol Cell 16: 4124-4138.

Geffroy V, Sicard D, de Oliveira JC, Sevignac M, Cohen S, Gepts P, Neema C, Langin T, Dron M. 1999. Identification of an ancestral resistance gene cluster involved in the coevolution process between phaseolus vulgaris and its fungal pathogen colletotrichum lindemuthianum. Mol Plant Microbe Interact 12: 774-784.

Geiser DM, Jiménez-Gasco MM, Kang S, Makalowska I, Veeraraghavan N, Ward TJ, Zhang N, Kuldau A, O'Donnell K. 2004. Fusarium-id v. 1.0:
A DNA sequence database for identifying fusarium. European Journal of Plant Pathology 110: 473-479.

Gerlanch W, Niremberg H. 1982. The genus fusarium: A pictorical atlas. Mitteilungen aus der Biologischen Bundesansalt für Land und Forstwirschaft 209.

Ghildiyal M, Zamore PD. 2009. Small silencing rnas: An expanding universe. Nat Rev Genet 10: 94-108.

Glass NL, Jacobson DJ, Shiu PK. 2000. The genetics of hyphal fusion and vegetative incompatibility in filamentous ascomycete fungi. Annu Rev Genet 34: 165-186.

Goldoni M, Azzalin G, Macino G, Cogoni C. 2004. Efficient gene silencing by expression of double stranded rna in neurospora crassa. Fungal Genet Biol 41: 1016-1024.

Gordon TR, Martyn RD. 1997. The evolutionary biology of fusarium oxysporum. Annu Rev Phytopathol 35: 111-128.

Goswami RS, Kistler CH. 2004. Heading for disaster: Fusarium graminearum on cereal crops. Molecular Plant Pathology 5: 515-525.

Guadet J, Julien J, Lafay JF, Brygoo Y. 1989. Phylogeny of some fusarium species, as determined by largesubunit rrna sequence comparison. Mol Biol Evol 6: 227-242.

Guindon S, Gascuel O. 2003. A simple, fast, and accurate algorithm to estimate large phylogenies by maximum 
likelihood. Syst Biol 52: 696-704.

Guo H, Ecker JR. 2004. The ethylene signaling pathway: New insights. Curr Opin Plant Biol 7: 40-49.

Guzmán P, Gilbertson RL, Nodari R, Johnson WC, Temple SR, Mandala D, Mkandawire ABC, Geps P. 1995. Characterization of variability in the fungus phaeoisariopsis griseo suggests coevolution with the common bean (phaseolus vulgaris). Phytopathology 85: 600-607.

Halvorsen YD, Nandabalan K, Dickson RC. 1991. Indetification of base recognition and high-affinity binding by lac9, a transcription activator containing a c6 zinc finger. Mol Cell Biol 11: 17771784.

Hamada W, Spanu PD. 1998. Cosuppression of the hydrophobin gene hcf- 1 is correlated with antisense rna biosynthesis in cladosporium fulvum. Mol Gen Genet 259: 630-638.

Han $\mathbf{Y}$, Liu X, Benny $\mathbf{U}$, Kistler $\mathbf{C H}$, VanEtten HD. 2001. Genes determining pathogenicity to pea are clustered on a supernumerary chromosome in the fungal plant pathogen nectria haematococca. The Plant Journal 25: 305-314.

Hanahan D, Jesee J, Bloom FR. 1991. Plasmid transformation of escherichia coli and other bacteria. Methods in Enzymology 204: 63-114.

Hasper AA, Trindade LM, van der Veen D, van Ooyen AJ, de Graaff LH. 2004. Functional analysis of the transcriptional activator $\mathrm{xInr}$ from aspergillus niger. Microbiology 150: 1367-1375.

Hatta R, Ito K, Hosaki Y, Tanaka T, Tanaka A, Yamamoto M, Akimitsu $\mathrm{K}$, Tsuge T. 2002. A conditionally dispensable chromosome controls host-specific pathogenicity in the fungal plant pathogen alternaria alternata. Genetics 161: 59-70.

Hatta R, Shinjo A, Ruswandi S, Kitani K, Yamamoto M, Akimitsu K, Tsuge T. 2006. DNA transposon fossils present on the conditional dispensable controls host-specific pathogenicity in the fungal plant pathogen alternaria alternata. Genetics 161: 59-70.

He C, Rusu AG, Poplawski AM, Irwin JA, Manners JM. 1998. Transfer of a supernumerary chromosome between vegetatively incompatible biotypes of the fungus colletotrichum gloeosporioides. Genetics 150: 14591466.

Hedbacker K, Carlson M. 2008. Snf1/ampk pathways in yeast. Front Biosci 13: 2408-2420.

Higuchi R, Dollinger G, Walsh PS, Griffith R. 1992. Simultaneous amplification and detection of specific DNA sequences. Biotechnology (N Y) 10: 413-417.

Higuchi R, Fockler C, Dollinger G, Watson R. 1993. Kinetic pcr analysis: Realtime monitoring of DNA amplification reactions. Biotechnology ( $N$ Y) 11: 1026-1030. 
Houterman PM, Speijer D, Dekker HL, de Koster CG, Cornelissen B, Rep M. 2007. The mixed proteome of fusarium oxysporum infected tomato xylem vessels. Mol Plant Pathol 8: 215-221.

Hua-Van A, Langin T, Daboussi MJ. 2001. Evolutionary history of the impala transposon in fusarium oxysporum. Mol Biol Evol 18: 1959-1969.

Hutcheson SW. 1998. Current concepts of active defense in plants. Annu Rev Phytopathol 36: 59-90.

Idnurm A, Howlett BJ. 2001. Pathogenicity genes of phytopathogenic fungi. Molecular Plant Pathology 2: 241-255.

Imazaki I, Kurahashi M, lida Y, Tsuge T. 2007. Fow2, a zn(ii)2cys6-type transcription regulator, controls plant infection of the vascular wilt fungus fusarium oxysporum. Mol Microbiol 63: 737-753.

Ito S, Kawaguchi T, Nagata A, Tamura H, Matsushita H, Takahara H, Tanaka S, Ikeda T. 2004. Distribution of the fotomi gene encoding tomatinase in formae speciales of fusarium oxysporum and identification of a novel tomatinase from f. Oxysporum f. Sp. Radicis-lycopersici, the causal agent of fusarium crown and root rot of tomato.

J. Gen. Plant Pathol. 70: 195-201.

Jain S, Akiyama K, Kan T, Ohguchi T, Takata R. 2003. The $g$ protein beta subunit fgb1 regulates development and pathogenicity in fusarium oxysporum. Curr Genet 43: 79-86.

Jain S, Akiyama K, Mae K, Ohguchi T,
Takata R. 2002. Targeted disruption of a g protein alpha subunit gene results in reduced pathogenicity in fusarium oxysporum. Curr Genet 41: 407-413.

Jain S, Akiyama K, Takata R, Ohguchi T. 2005. Signaling via the $g$ protein alpha subunit fga2 is necessary for pathogenesis in fusarium oxysporum. FEMS Microbiol Lett 243: 165-172.

Janus D, Hoff B, Hofmann E, Kück U. 2007. An efficient fungal rna-silencing system using the dsred reporter gene. Appl Environ Microbiol 73: 962-970.

Johnson LJ, Johnson RD, Akamatsu H, Salamiah A, Otani H, Kohmoto K, Kodama M. 2001. Spontaneous loss of a conditionally dispensable chromosome from the alternaria alternata apple pathotype leads to loss of toxin production and pathogenicity. Curr Genet 40: 65-72.

Johnston M, Dover J. 1987. Mutations that inactivate a yeast transcriptional regulatory protein cluster in an evolutionarily conserved DNA binding domain. Proc Natl Acad Sci U S A 84: 2401-2405.

Jones DA, Thomas CM, Hammond-Kosack KE, Balint-Kurti PJ, Jones JD. 1994. Isolation of the tomato cf-9 gene for resistance to cladosporium fulvum by transposon tagging. Science 266: 789793.

Jones JD, Dangl JL. 2006. The plant immune system. Nature 444: 323-329.

Kadotani N, Nakayashiki H, Tosa Y, Mayama S. 2003. Rna silencing in the 
phytopathogenic fungus magnaporthe oryzae. Mol Plant Microbe Interact 16: 769-776.

Kang S, Lebrun MH, Farrall L, Valent B. 2001. Gain of virulence caused by insertion of a pot3 transposon in a magnaporthe grisea avirulence gene. Mol Plant Microbe Interact 14: 671674.

Kerenyi Z, Moretti A, Waalwijk C, Olah B, Hornok L. 2004. Mating type sequences in asexually reproducing fusarium species. Appl Environ Microbiol 70: 4419-4423.

Kers JA, Cameron KD, Joshi MV, Bukhalid RA, Morello JE, Wach MJ, Gibson DM, Loria R. 2005. A large, mobile pathogenicity island confers plant pathogenicity on streptomyces species. Mol Microbiol 55: 1025-1033.

Kwak M, Gepts P. 2009. Structure of genetic diversity in the two major gene pools of common bean (phaseolus vulgaris I., fabaceae). Theor Appl Genet 118: 979-992.

Lacroix H, Spanu PD. 2009. Silencing of six hydrophobins in cladosporium fulvum: Complexities of simultaneously targeting multiple genes. Appl Environ Microbiol 75: 542-546.

Laday M, Szecsi A. 2002. Identification of fusarium species by isozyme analysis. Acta Microbiol Immunol Hung 49: 321 330.

Lagopodi AL, Ram AF, Lamers GE, Punt PJ, Van den Hondel CA, Lugtenberg BJ, Bloemberg GV. 2002. Novel aspects of tomato root colonization and infection by fusarium oxysporum $\mathrm{f}$. Sp. Radicis-lycopersici revealed by confocal laser scanning microscopic analysis using the green fluorescent protein as a marker. Mol Plant Microbe Interact 15: 172-179.

Laity JH, Lee BM, Wright PE. 2001. Zinc finger proteins: New insights into structural and functional diversity. Curr Opin Struct Biol 11: 39-46.

Larkin MA, Blackshields G, Brown NP, Chenna R, McGettigan PA, McWilliam H, Valentin F, Wallace IM, Wilm A, Lopez R, Thompson JD, Gibson TJ, Higgins DG. 2007. Clustal $\mathrm{W}$ and clustal $\mathrm{x}$ version 2.0 . Bioinformatics 23: 2947-2948.

Laurie JD, Linning R, Bakkeren G. 2008. Hallmarks of rna silencing are found in the smut fungus ustilago hordei but not in its close relative ustilago maydis. Curr Genet 53: 49-58.

Le Gouill C, Dery CV. 1991. A rapid procedure for the screening of recombinant plasmids. Nucleic Acids Res 19: 6655.

Leach J, Yoder OC. 1983. Heterokaryon incompatibility in the plant-pathogenic fungus cochliobulus heterostrophus. J. Hered. 74: 149-152.

Lechner J. 1994. A zinc finger protein, essential for chromosome segregation, constitutes a putative DNA binding subunit of the saccharomyces cerevisiae kinetochore complex. EMBO J 13: 5203-5211. 
Lee SH, Lee J, Lee S, Park EH, Kim KW, Kim MD, Yun SH, Lee YW. 2009. Gzsnf1 is required for normal sexual and asexual development in the ascomycete gibberella zeae. Eukaryot Cell 8: 116-127.

Leslie JF. 1993. Fungal vegetative compatibility. Annu Rev Phytopathol 31: 127-150.

Lievens $B$, Brouwer $M$, Vanachter AC, Cammue BP, Thomma BP. 2003. Rapid detection and identification of tomato vascular wilt pathogens using a DNA array. Commun Agric Appl Biol Sci 68: 569-581.

Lievens B, Brouwer M, Vanachter AC, Levesque CA, Cammue BP, Thomma BP. 2003. Design and development of a DNA array for rapid detection and identification of multiple tomato vascular wilt pathogens. FEMS Microbiol Lett 223: 113-122.

Lievens B, Rep M, Thomma BP. 2008. Recent developments in the molecular discrimination of formae speciales of fusarium oxysporum. Pest Manag Sci 64: 781-788.

Liu H, Cottrell TR, Pierini LM, Goldman WE, Doering TL. 2002. Rna interference in the pathogenic fungus cryptococcus neoformans. Genetics 160: 463-470.

Liu X, Inlow M, VanEtten HD. 2003. Expression profiles of pea pathogenicity ( pep) genes in vivo and in vitro, characterization of the flanking regions of the pep cluster and evidence that the pep cluster region resulted from horizontal gene transfer in the fungal pathogen nectria haematococca. Curr Genet 44: 95-103.

Liu Y, Yang Q. 2007. Cloning and heterologous expression of aspartic protease sa76 related to biocontrol in trichoderma harzianum. FEMS Microbiol Lett 277: 173-181.

Livak KJ, Flood SJ, Marmaro J, Giusti W, Deetz K. 1995. Oligonucleotides with fluorescent dyes at opposite ends provide a quenched probe system useful for detecting pcr product and nucleic acid hybridization. $P C R$ Methods Appl 4: 357-362.

Lockington RA, Borlace GN, Kelly JM. 1997. Pyruvate decarboxylase and anaerobic survival in aspergillus nidulans. Gene 191: 61-67.

MacPherson S, Larochelle M, Turcotte B. 2006. A fungal family of transcriptional regulators: The zinc cluster proteins. Microbiol Mol Biol Rev 70: 583-604.

Madrid MP, Di Pietro A, Roncero MI. 2003. Class $v$ chitin synthase determines pathogenesis in the vascular wilt fungus fusarium oxysporum and mediates resistance to plant defence compounds. Mol Microbiol 47: 257266.

Maerken TV, Mestdagh P, De Clercq S, Pattyn F, Yigit N, De Paepe A, Marine JC, Speleman F, Vandesompele J. 2009. Using realtime qpcr to evaluate rnai-mediated gene silencing. BioTechniques Protocol Guide 1: 47. 
Mamane Y, Hellauer K, Rochon MH, Turcotte B. 1998. A linker region of the yeast zinc cluster protein leu3p specifies binding to everted repeat DNA. J Biol Chem 273: 18556-18561.

MAPA. 2004. Anuario de estadística agroalimentaria. Evolución de las macromagnitudes agrarias nacionales. MAPA.

Martín-Rodrigues N, A. G-SM, Ramos B, De Vega JJ, Eslava AP, Diaz-Miguez JM. 2007. Estudio mediante microoscopia confocal de la infección de judía por fusarium oxysporum. Boletín de la Sociedad Española de Fitopatología 59: 5-8.

Martin-Urdiroz M, Roncero MI, GonzalezReyes JA, Ruiz-Roldan C. 2008. Chsvb, a class vii chitin synthase involved in septation, is critical for pathogenicity in fusarium oxysporum. Eukaryot Cell 7: 112-121.

Martinez JP, Oesch NW, Ciuffetti LM. 2004. Characterization of the multiple-copy host-selective toxin gene, toxb, in pathogenic and nonpathogenic isolates of pyrenophora tritici-repentis. Mol Plant Microbe Interact 17: 467-474.

Martinez JP, Ottum SA, Ali S, Franci LJ, Ciuffetti LM. 2001. Characterization of the toxb gene from pyrenophora triticirepentis. Mol Plant Microbe Interact 14: 675-677.

Martinez-Rocha AL, Roncero MI, LopezRamirez A, Marine M, Guarro J, Martinez-Cadena G, Di Pietro A. 2008. Rho1 has distinct functions in morphogenesis, cell wall biosynthesis and virulence of fusarium oxysporum. Cell Microbiol 10: 1339-1351.

Matityahu A, Hadar Y, Dosoretz CG, Belinky PA. 2008. Gene silencing by rna interference in the white rot fungus phanerochaete chrysosporium. Appl Environ Microbiol 74: 5359-5365.

McDonald T, Brown D, Keller NP, Hammond TM. 2005. Rna silencing of mycotoxin production in aspergillus and fusarium species. Mol Plant Microbe Interact 18: 539-545.

McGuire TM, Carvajal E, Katzmann D, Wagner M, Moye-Rowley WS, Gosffeau A, Golin J. 1995. Analysis of second-site mutations that suppress the multiple drug resistance phenotype of the yeast pdr1-7 allele. Gene 167: 151-155.

Mendgen K, Hahn M. 2002. Plant infection and the establishment of fungal biotrophy. Trends Plant Sci 7: 352356.

Michielse CB. 2005. Agrobacterium-mediated transformation as a tool for functional genomics in fungi. Curr Genet 48, 1: 1 $-17$.

Michielse CB, Rep M. 2009. Pathogen profile update: Fusarium oxysporum. Mol Plant Pathol 10: 311-324.

Migueli Q, Berio T, Gullino ML. 1993. Electrophoretic karyotypes of fusarium spp. Experimental mycology 17: 327329.

Mirete S, Patino B, Vazquez C, Jimenez M, Hinojo MJ, Soldevilla C, Gonzalez- 
Jaen MT. 2003. Fumonisin production by gibberella fujikuroi strains from pinus species. Int J Food Microbiol 89: 213-221.

Moller EM, Bahnweg G, Sandermann H, Geiger HH. 1992. A simple and efficient protocol for isolation of high molecular weight DNA from filamentous fungi, fruit bodies, and infected plant tissues. Nucleic Acids Res 20: 6115-6116.

Moriwaki A, Ueno M, Arase S, Kihara J. 2007. Rna-mediated gene silencing in the phytopathogenic fungus bipolaris oryzae. FEMS Microbiol Lett 269: 8589.

Mouyna I, Henry C, Doering TL, Latge JP. 2004. Gene silencing with rna interference in the human pathogenic fungus aspergillus fumigatus. FEMS Microbiol Lett 237: 317-324.

Mullins ED, Chen X, Romaine P, Raina R, Geiser DM, Kang S. 2001. Agrobacterium-mediated transformation of fusarium oxysporum: An efficient tool for insertional mutagenesis and gene transfer. Phytopathology 91: 173-180.

Nakayashiki H. 2005. Rna silencing in fungi: Mechanisms and applications. FEBS Lett 579: 5950-5957.

Nakayashiki H, Hanada S, Nguyen BQ, Kadotani N, Tosa Y, Mayama S. 2005. Rna silencing as a tool for exploring gene function in ascomycete fungi. Fungal Genet Biol 42: 275-283.

Nakayashiki H, Kadotani N, Mayama S.
2006. Evolution and diversification of rna silencing proteins in fungi. $J \mathrm{Mol}$ Evol 63: 127-135.

Nakayashiki H, Nguyen QB. 2008. Rna interference: Roles in fungal biology. Curr Opin Microbiol 11: 494-502.

Namekawa SH, Iwabata K, Sugawara H, Hamada FN, Koshiyama A, Chiku H, Kamada T, Sakaguchi K. 2005. Knockdown of $\lim 15 /$ dmc1 in the mushroom coprinus cinereus by double-stranded rna-mediated gene silencing. Microbiology 151: 36693678.

Namiki F, Matsunaga M, Okuda M, Inoue I, Nishi K, Fujita Y, Tsuge T. 2001. Mutation of an arginine biosynthesis gene causes reduced pathogenicity in fusarium oxysporum f. Sp. Melonis. Mol Plant Microbe Interact 14: 580584.

Nelson PE, Desjardins AE, Plattner RD. 1993. Fumonisins, mycotoxins produced by fusarium species: Biology, chemistry, and significance. Annu Rev Phytopathol 31: 233-252.

Nelson PE, Tousson TA, Marassas WFO. 1983. Fusarium species: An ilustrated manual for identification. Pennsylvania State University Press. EEUU.

Ngo H, Tschudi C, Gull K, Ullu E. 1998. Double-stranded rna induces mrna degradation in trypanosoma brucei. Proc Natl Acad Sci U S A 95: 1468714692

Nguyen QB, Kadotani N, Kasahara S, Tosa Y, Mayama S, Nakayashiki H. 2008. 
Systematic functional analysis of calcium-signalling proteins in the genome of the rice-blast fungus, magnaporthe oryzae, using a highthroughput rna-silencing system. Mol Microbiol 68: 1348-1365.

Nguyen QB, Kadotani N, Kasahara S, Tosa Y, Mayama S, Nakayashiki H. 2008. Systematic functional analysis of calcium-signalling proteins in the genome of the rice-blast fungus, magnaporthe oryzae, using a highthroughput rna-silencing system. Mol Microbiol 68: 1348-1365.

Nicolas FE, Torres-Martinez S, RuizVazquez RM. 2003. Two classes of small antisense rnas in fungal rna silencing triggered by non-integrative transgenes. EMBO J 22: 3983-3991.

Nuñez Corcuera B. 2004. Detección y expresión de los genes ftf1 y ftf2 en formas especiales del hongo fitopatógeno fusarium oxysporum. Tesina de Grado. Universidad de Salamanca.

O'Donnell K, Kistler HC, Cigelnik E, Ploetz RC. 1998. Multiple evolutionary origins of the fungus causing panama disease of banana: Concordant evidence from nuclear and mitochondrial gene genealogies. Proc Natl Acad Sci U S A 95: 2044-2049.

O'Donnell K, Kistler HC, Tacke BK, Casper HH. 2000. Gene genealogies reveal global phylogeographic structure and reproductive isolation among lineages of fusarium graminearum, the fungus causing wheat scab. Proc Natl Acad Sci U S A 97: 7905-7910.

Ortoneda M, Guarro J, Madrid MP, Caracuel Z, Roncero MI, Mayayo E, Di Pietro A. 2004. Fusarium oxysporum as a multihost model for the genetic dissection of fungal virulence in plants and mammals. Infect Immun 72: 1760-1766.

Ospina-Giraldo MD, Mullins E, Kang S. 2003. Loss of function of the fusarium oxysporum snf1 gene reduces virulence on cabbage and arabidopsis. Curr Genet 44: 49-57.

Pan T, Coleman JE. 1990. Gal4 transcription factor is not a "Zinc finger" But forms a zn(ii)2cys6 binuclear cluster. Proc Natl Acad Sci U S A 87: 2077-2081.

Pareja-Jaime Y, Roncero MI, Ruiz-Roldan MC. 2008. Tomatinase from fusarium oxysporum f. Sp. Lycopersici is required for full virulence on tomato plants. Mol Plant Microbe Interact 21: 728-736.

Park HD, Luche RM, Cooper TG. 1992. The yeast ume6 gene product is required for transcriptional repression mediated by the car 1 urs 1 repressor binding site. Nucleic Acids Res 20: 1909-1915.

Pastor-Corrales MA, Abawi GS. 1987. Reactions of selected bean germplasm to infection by fusarium oxysporum f.Sp. Phaseoli. Plant Disease 71: 990993.

Penalva MA, Arst HN, Jr. 2002. Regulation of gene expression by ambient ph in filamentous fungi and yeasts. Microbiol 
Mol Biol Rev 66: 426-446, table of contents.

Perfect SE, Hughes HB, O'Connell RJ, Green JR. 1999. Colletotrichum: A model genus for studies on pathology and fungal-plant interactions. Fungal Genet Biol 27: 186-198.

Pfaffl MW. 2001. A new mathematical model for relative quantification in real-time rtpcr. Nucleic Acids Res 29: e45.

Prados Rosales RC, Di Pietro A. 2008. Vegetative hyphal fusion is not essential for plant infection by fusarium oxysporum. Eukaryot Cell 7: 162-171.

Proctor RH, Hohn TM, McCornick SP, Desjardins AE. 1995. Tri6 encodes an unusual zinc finger protein involved in regulation of trichothecene biosynthesis in fusarium sporotrichioides. Appl Environ Microbiol 61: 1923-1930.

Puhalla JE. 1985. Classification of strains of fusarium oxysporum on the basis of vegetative compatibility. Can J Bot 63: 179-183.

Ramos B. 2005. Análisis de factores de patogenicidad y virulencia en el hongo fusarium oxysporum f.Sp. Phaseoli. Tesis Doctoral. Universidad de Salamanca.

Ramos B, Alves-Santos FM, GarcíaSánchez MA, Martín-Rodrigues N, Eslava AP, Díaz-Mínguez JM. 2007. The gene coding for a new transcription factor (ftf1) of fusarium oxysporum is only expressed during infection of common bean. Fungal
Genet Biol 44(9): 864-876.

Rep M, Meijer M, Houterman PM, van der Does HC, Cornelissen BJ. 2005. Fusarium oxysporum evades i-3mediated resistance without altering the matching avirulence gene. $\mathrm{Mol}$ Plant Microbe Interact 18: 15-23.

Rep M, van der Does HC, Cornelissen BJ. 2005. Drifter, a novel, low copy hat-like transposon in fusarium oxysporum is activated during starvation. Fungal Genet Biol 42: 546-553.

Rocha AL, Di Pietro A, Ruiz-Roldan C, Roncero MI. 2008. Ctf1, a transcriptional activator of cutinase and lipase genes in fusarium oxysporum is dispensable for virulence. Mol Plant Pathol 9: 293-304.

Rohe M, Gierlich A, Hermann H, Hahn M, Schmidt B, Rosahl S, Knogge W. 1995. The race-specific elicitor, nip1, from the barley pathogen, rhynchosporium secalis, determines avirulence on host plants of the rrs1 resistance genotype. EMBO $J$ 14: 4168-4177.

Romano N, Macino G. 1992. Quelling: Transient inactivation of gene expression in neurospora crassa by transformation with homologous sequences. Mol Microbiol 6: 33433353.

Rowe RC. 1980. Comparative pathogenicity and host ranges of fusarium oxysporum isolates causing crown and root rot of greenhouse and field-grown tomatoes in north america and japan. 
Phytopathology 70: 1143-1148.

Sacristán S, García-Arenal F. 2008. The evolution of virulence and pathogenicity in plant pathogen populations. Molecular Plant Pathology 9: 369-384.

Saiki RK, Scharf S, Paloona F. 1985. Enzimatic amplification of b-globin genomic sequences and restriction analysis for diagnosis of sickle cell anemia. Science 230: 1350-1354.

Sambrook J, Fristsch EF, Maniatis T. 1989. Molecular cloning. A laboratory manual: Cold Spring Harbor Laboratory Press.

Sanz P, Ludin K, Carlson M. 2000. Sip5 interacts with both the reg1/glc7 protein phosphatase and the snf1 protein kinase of saccharomyces cerevisiae. Genetics 154: 99-107.

Schjerling P, Holmberg S. 1996. Comparative amino acid sequence analysis of the c6 zinc cluster family of transcriptional regulators. Nucleic Acids Res 24: 4599-4607.

Shafran H, Miyara I, Eshed R, Prusky D, Sherman A. 2008. Development of new tools for studying gene function in fungi based on the gateway system. Fungal Genet Biol 45(8): 1147-1154.

Simons G, Groenendijk J, Wijbrandi J, Reijans M, Groenen J, Diergaarde P, Van der Lee T, Bleeker M, Onstenk $J$, de Both $M$, Haring $M$, Mes J, Cornelissen B, Zabeau M, Vos P. 1998. Dissection of the fusarium i2 gene cluster in tomato reveals six homologs and one active gene copy.

Plant Cell 10: 1055-1068.

Skory CD. 2003. Induction of rhizopus oryzae pyruvate decarboxylase genes. Curr Microbiol 47: 59-64.

Snyder WC, Hansen HN. 1940. The species concept in fusarium. Am. J. Bot. 27: 64-67.

Solomon PS, Tan KC, Oliver RP. 2003. The nutrient supply of phytopathogenic fungi; a fertile field of study. Mol Plant Pathology 4: 203-210.

Spiering MJ, Moon CD, Wilkinson $\mathrm{HH}$, SchardI CL. 2005. Gene clusters for insecticidal loline alkaloids in the grass-endophytic fungus neotyphodium uncinatum. Genetics 169: $1403-1414$

Strelkov SE, Lamar L, Sayoud R, Smith RB. 2002. Comparative virulence of chlorosis-inducing races of pyrenophora tritici-repentis. Can J. Plant Pathology-Rev. Can. Phytopathology 24: 29-35.

Strelkov SE, Lamari L, Ballance GM. 1999. Characterization of a host-specific protein toxin (ptr toxb) from pyrenophora trtici-repentis. Mol. PlantMicrobe Interact. 12. 1-12

Strich R, Surosky RT, Steber C, Dubois E, Messenguy F, R.E. E. 1994. Ume6 is a key regulator of nitrogen repression and meiotic development. Genes Dev 8: 796-810.

Suárez T, de Queiroz MV, Oestreicher N, Scazzocchio C. 1995. The sequence and binding specificity of uay, the 
specific regulator of the purine utilization pathway in aspergillus nidulans, suggest an evolutionary relationship with the ppr1 protein of saccharomyces cerevisiae. EMBO J 14: $1453-1467$.

Sze JY, Remboutsika E, Kohlhaw GB. 1993. Transcriptional regulator leu3 of saccharomyces cerevisiae: Separation of activator and repressor functions. Mol Cell Biol 13: 5702-5709.

Tan MK, Niessen LM. 2003. Analysis of rdna its sequences to determine genetic relationships among, and provide a basis for simplified diagnosis of, fusarium species causing crown rot and head blight of cereals. Mycol Res 107: 811-821.

Temporini ED, VanEtten HD. 2004. An analysis of the phylogenetic distribution of the pea pathogenicity genes of nectria haematococca mpvi supports the hypothesis of their origin by horizontal transfer and uncovers a potentially new pathogen of garden pea: Neocosmospora boniensis. Curr Genet 46: 29-36.

Teunissen HA, Verkooijen J, Cornelissen BJ, Haring MA. 2002. Genetic exchange of avirulence determinants and extensive karyotype rearrangements in parasexual recombinants of fusarium oxysporum. Mol Genet Genomics 268: 298-310.

Thomma BP, Nelissen I, Eggermont K, Broekaert WF. 1999. Deficiency in phytoalexin production causes enhanced susceptibility of arabidopsis thaliana to the fungus alternaria brassicicola. Plant J 19: 163-171.

Thon MR, Pan H, Diener S, Papalas J, Taro A, Mitchell TK, Dean RA. 2006. The role of transposable element clusters in genome evolution and loss of synteny in the rice blast fungus magnaporthe oryzae. Genome Biol 7: R16.

Thrall PH, Burdon JJ, Bever JD. 2002. Local adaptation in the linum marginalemelampsora lini host-pathogen interaction. Evolution 56: 1340-1351.

Todd RB, Andrianopoulos A. 1997. Evolution of a fungal regulatory gene family: The zn(ii)2cys6 cluster DNA binding motif. Fungal Genet Biol 21: 388-405.

Todd RB, Fraser JA, Wong KH, Davis MA, Hynes MJ. 2005. Nuclear accumulation of the gata factor area in response to complete nitrogen starvation by regulation of nuclear export. Eukaryot Cell 4: 1646-1653.

Tonukari NJ, Scott-Craig JS, Walton JD. 2000. The cochliobolus carbonum snf1 gene is required for cell wall-degrading enzyme expression and virulence on maize. Plant Cell 12: 237-248.

Tsuji G, Kenmochi Y, Takano Y, Sweigard J, Farrall L, Furusawa I, Horino O, Kubo Y. 2000. Novel fungal transcriptional activators, $\mathrm{cmr} 1 \mathrm{p}$ of colletotrichum lagenarium and pig1p of magnaporthe grisea, contain cys2his2 zinc finger and zn(ii)2cys6 binuclear 
cluster DNA-binding motifs and regulate transcription of melanin biosynthesis genes in a developmentally specific manner. Mol Microbiol 38: 940-954.

Tudzynski B. 2005. Gibberellin biosynthesis in fungi: Genes, enzymes, evolution, and impact on biotechnology. Appl Microbiol Biotechnol 66: 597-611.

Ullán RV, Godio RP, Teijeira F, Vaca I, García-Estrada C, Feltrer R, Kosalkova K, Martín JF. 2008. Rnasilencing in penicillium chrysogenum and acremonium chrysogenum: Validation studies using beta-lactam genes expression. J Microbiol Methods 75(2): 209-218.

Valverde F. 1978. The organization of area 18 in the monkey. A golgi study. Anat Embryol (Berl) 154: 305-334.

van der Does HC, Lievens B, Claes L, Houterman PM, Cornelissen BJ, Rep M. 2008. The presence of a virulence locus discriminates fusarium oxysporum isolates causing tomato wilt from other isolates. Environ Microbiol 10: 1475-1485.

van der Does HC, Rep M. 2007. Virulence genes and the evolution of host specificity in plant-pathogenic fungi. Mol Plant Microbe Interact 20: 11751182.

Velasquez VL, Gepts P. 1994. Rflp diversity of common bean (phaseolus vulgaris) in its centres of origin. Genome 37: 256-263.

Voigt K, Schleier S, Bruckner B. 1995.
Genetic variability in gibberella fujikuroi and some related species of the genus fusarium based on random amplification of polymorphic DNA (rapd). Curr Genet 27: 528-535.

Voinnet O. 2008. Use, tolerance and avoidance of amplified rna silencing by plants. Trends Plant Sci 13: 317-328.

Wei ZM, Laby RJ, Zumoff CH, Bauer DW, He SY, Collmer A, Beer SV. 1992. Harpin, elicitor of the hypersensitive response produced by the plant pathogen erwinia amylovora. Science 257: 85-88.

Weld RJ, Plummer KM, Carpenter MA, Ridgway HJ. 2006. Approaches to functional genomics in filamentous fungi. Cell Res 16: 31-44.

Winnenburg $R$, Urban $M$, Beacham $A$, Baldwin TK, Holland S, Lindeberg M, Hansen $\mathrm{H}$, Rawlings C, Hammond-Kosack KE, Kohler J. 2008. Phi-base update: Additions to the pathogen host interaction database. Nucleic Acids Res 36: D572-576.

Wu SC, Halley JE, Luttig C, Fernekes LM, Gutierrez-Sanchez G, Darvill AG, Albersheim P. 2006. Identification of an endo-beta-1,4-d-xylanase from magnaporthe grisea by gene knockout analysis, purification, and heterologous expression. Appl Environ Microbiol 72: 986-993.

Yang $Q$, Trinh HX, Imai S, Ishihara A, Zhang L, Nakayashiki H, Tosa Y, Mayama S. 2004. Analysis of the 
involvement of hydroxyanthranilate hydroxycinnamoyltransferase and caffeoyl-coa 3-o-methyltransferase in phytoalexin biosynthesis in oat. $\mathrm{Mol}$ Plant Microbe Interact 17: 81-89.

Yi M, Park JH, Ahn JH, Lee YH. 2008. Mosnf1 regulates sporulation and pathogenicity in the rice blast fungus magnaporthe oryzae. Fungal Genet Biol 45: 1172-1181.

Yuan GF, Fu YH, Marzluf GA. 1991. Nit-4, a pathway-specific regulatory gene of neurospora crassa, encodes a protein with a putative binuclear zinc DNAbinding domain. Mol Cell Biol 11: 5735-5745.

Yun SH, Arie T, Kaneko I, Yoder OC, Turgeon BG. 2000. Molecular organization of mating type loci in heterothallic, homothallic, and asexual gibberella/fusarium species. Fungal Genet Biol 31: 7-20. 




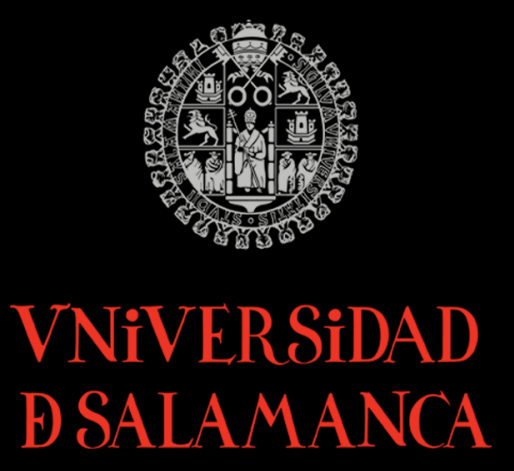

Centro Hispano Luso de Investigaciones Agrarias

Departamento de Mierobiología y Genética

Área de Genética
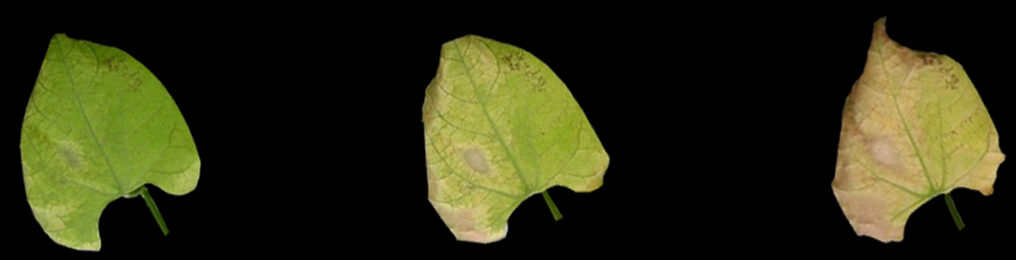